Antônio Francisco Arcanjo de Araújo Melo

\title{
Nanopartículas de Magnetita Aplicadas no Controle Comutável da Transferência de Elétrons de Proteínas Redox e na Construção de Padrões de Litografia Magnética
}

Tese apresentada ao Instituto de Química de São Carlos da Universidade de São Paulo como parte dos requisitos para obtenção do título de doutor em ciências.

Área de concentração: Físico-Química

Orientador: Prof. Dr. Frank Nelson Crespilho

\section{Exemplar revisado}

O exemplar original encontra-se em acervo reservado na Biblioteca do IQSC-USP

São Carlos 


\section{Dedicatória}

Dedico este trabalho a toda minha família e, em especial aos meus pais Antônio Arcanjo de Araújo e Maria do Carmo Melo da Silva; e ao meu irmão Antônio Arcanjo de Araújo Júnior. 


\section{Agradecimentos}

- A Deus, pelo dom da vida a mim concedido;

- Aos meus pais Antônio Arcanjo de Araújo e Maria do Carmo Melo da Silva, pelos ensinamentos de vida que me foram passados, prezando sempre pela honestidade, humildade e respeito para com todos;

- Ao meu orientador Prof. Dr. Frank Nelson Crespilho, pela paciência e incentivo durante a realização deste trabalho;

- Ao professor Dr. Katsuhiko Ariga, pela confiança em mim depositada;

- A todos os colaboradores do Instituto Nacional de Ciência dos Materiais, em especial, ao Dr. Joel Henzie e a doutoranda Izabela Osica, pela forte parceria desenvolvida durante o estágio de doutorado sanduíche realizado no Japão.

- A todos os alunos do Grupo de Bioeletroquímica e Interfaces, em especial, aos amigos Vitor Alexandre Nunes de Carvalho, Roberto Alves de Sousa Luz, Rodrigo Michelin Iost, pelo apoio nos momentos difíceis e por todas as alegrias compartilhadas;

- A todos os amigos e professores da Universidade de São Paulo que de maneira direta e indireta participaram da minha formação acadêmica;

- Ao CNPq e à Rede NanobioMed, pela bolsa de doutorado concedida, fundamental para o desenvolvimento deste trabalho. 
"O sábio não é aquele que sabe de tudo, mas sim aquele que usa tudo que sabe..." 


\section{Resumo}

Atualmente, aplicações de nanopartículas de magnetita $\left(\mathrm{NPs}-\mathrm{Fe}_{3} \mathrm{O}_{4}\right)$ têm sido comumente reportadas em inúmeros trabalhos descritos na literatura. Catálise, ferrofluidos e dispositivos de armazenamento de dados são algumas delas. Além disso, aplicações biomédicas têm sido demonstradas. Para esse último, têm-se os exemplos de magneto-hipertermia, liberação controlada de fármacos, agente de contraste em imagens de ressonância magnética e o controle de reações bioeletrocatalíticas envolvendo enzimas redox. Nesta tese, $\mathrm{NPs}-\mathrm{Fe}_{3} \mathrm{O}_{4}$ foram aplicadas em duas vertentes inéditas. Dessa forma, tendo em vista uma melhor compreensão, a sua escrita foi dividida em dois capítulos, nos quais abordam separadamente cada uma dessas vertentes. O primeiro capítulo descreve a obtenção, modificação e funcionalização de $\mathrm{NPs}_{-} \mathrm{Fe}_{3} \mathrm{O}_{4}$ a afim de usá-las como uma plataforma para a imobilização do citocromo c (Cyt c); uma proteína redox de comportamento modelo dotada de um grupo prostético heme em sua estrutura terciária. Em seguida, após um efetivo processo de imobilização do Cyt c sobre as $\mathrm{NPs}-\mathrm{Fe}_{3} \mathrm{O}_{4}$ com superfície modificada, o uso de um campo magnético externo possibilitou a deposição do mesmo na interface eletródica, estabelecendo a reação de transferência direta de elétrons entre o grupo heme e a superfície metálica do eletrodo de trabalho. Além disso, por meio da permuta entre os estados comutáveis switch on e switch off, obteve-se o controle magnético comutável da reação de transferência direta de elétrons do Cyt c quando imobilizado na superfície das $\mathrm{NPs}_{-} \mathrm{Fe}_{3} \mathrm{O}_{4}$ com superfície modificada. Já para o segundo capítulo, $\mathrm{NPs}-\mathrm{Fe}_{3} \mathrm{O}_{4}$ foram utilizadas como adesivo magnético a fim de capturar nanoestruturas metálicas hollow (nanocages bimetálicos de $\mathrm{Au} / \mathrm{Ag}$ ) dispersas em suspensão aquosa. Dessa forma, por meio da influência de um campo magnético constante, os aglomerados formados entre esses dois nanomateriais foram depositados sobre uma máscara litográfica, levando a formação de padrões de litografia magnética dispostos sobre a superfície de um substrato de ITO (vidro recoberto com óxido de estanho dopado com índio). Imagens de microscopia eletrônica de varredura (MEV) comprovaram que a metodologia utilizada para o preparo dos padrões litográficos foi eficaz, apresentando um alto rendimento na obtenção dos mesmos. Além disso, realizou-se com sucesso o mapeamento químico de infravermelho dos padrões litográficos dispostos sobre o ITO. Para isso, empregou-se como alvo os modos vibracionais do polímero polivinilpirrolidona (PVP) utilizado na modificação da superfície dos nanocages bimetálicos de Au/Ag. Por fim, acredita-se que os padrões litográficos arranjados em macroescala, juntamente com os aglomerados de nanocages bimetálicos alinhados na forma de microfios, possuem potencial aplicação em estudos de espectroscopia de absorção no infravermelho intensificado por superfície (SEIRA).

Palavras-chave: Nanopartículas de magnetita com superfície modificada; Controle magnético da transferência direta de elétrons do citocromo c; Captura de nanocages bimetálicos de Au/Ag; Adesivo magnético; Padrões de litografia magnética. 


\begin{abstract}
Currently, applications of magnetite nanoparticles ( $\mathrm{Fe}_{3} \mathrm{O}_{4}-\mathrm{NPs}$ ) have been commonly reported in many studies in the literature. Catalysis, ferrofluids and data storage devices are some of them. Moreover, biomedical applications have been demonstrated. For the latter, there are the following examples, such as magneto-hyperthermia, controlled release of drugs and the control of bioelectrocatalysis of the enzymatic reactions. In this thesis, $\mathrm{Fe}_{3} \mathrm{O}_{4}-\mathrm{NPs}$ were used in two new applications. Therefore, towards a better understanding its writing was divided into two chapters, which each one of them reports separately these two applications. The first chapter describes the synthesis, modification and functionalization of $\mathrm{Fe}_{3} \mathrm{O}_{4}-\mathrm{NPs}$ in order to use them as a platform for the immobilization of cytochrome $\mathrm{c}(\mathrm{Cyt} \mathrm{c})$; model redox protein which possess a heme prosthetic group in its tertiary structure. Then, after an effective immobilization of Cyt $\mathrm{c}$ on surface-modified $\mathrm{Fe}_{3} \mathrm{O}_{4}-\mathrm{NPs}$, the use of an external magnetic field permitted the deposition of this redox protein on the electrode interface, establishing the reaction of direct electron transfer between heme prosthetic group and the metallic surface of the working electrode. Furthermore, by the exchange between ON and OFF switch modes was obtained the magnetic control of the direct electron transfer of Cyt $\mathrm{c}$ when immobilized on the surfacemodified $\mathrm{Fe}_{3} \mathrm{O}_{4}$-NPs. For the second chapter, $\mathrm{Fe}_{3} \mathrm{O}_{4}-\mathrm{NPs}$ were used as magnetic adhesive to capture hollow metallic nanostructures (Au-Ag bimetallic nanocages) dispersed in aqueous suspension. Thus, by use of a constant magnetic field, the agglomerates formed between these two nanomaterials were deposited on a lithographic mask, leading to formation of magnetolithograph patterns on the surface of ITO substrate (glass coated with oxide tin-doped indium). Scanning electron microscopy images (SEM) showed that the methodology used for the high-yield preparation of lithographicpatterns was effective. Furthermore, the FTIR chemical mapping of the lithographic patterns arranged on the ITO's surface was successfully performed. For this, the $\mathrm{CH}_{2}$ and $\mathrm{C}-\mathrm{N}, \mathrm{C}=\mathrm{O}$ vibrational modes of the polyvinylpyrrolidone polymer (PVP) used for the surface modification of Au-Ag bimetallic nanocages were employed as target. Finally, we believed that magnetolithograph patterns arranged in microscale on the ITO surface, and also the clusters of the bimetallic nanocages aligned as micro-wires show potential application in surface-enhanced infrared absorption (SEIRA).
\end{abstract}

Keywords: Surface-modified magnetite nanoparticles; Magnetic control of the electrons direct transfer of cytochrome c; Capture of Au-Ag bimetallic nanocages; Magnetic adhesive; Magnetolithograph patterns. 


\section{Lista de figuras}

Figura 1- Ilustração esquemática do controle magnético comutável da separação de dois processos redox observados simultaneamente sobre a superfície de um eletrodo de ouro; modos switch off (a) e switch on (b).

Figura 2- (a) Representação cristalográfica do Cyt c (PDB: 3CYT); (b) Visão frontal do grupo prostético heme demostrando um átomo de ferro (em laranja) coordenado a quatro átomos de nitrogênio (em azul) em uma estrutura denominada porfirina.

Figura 3- Ilustração esquemática demonstrando a diferença nos valores das constantes de transferência de elétrons do Cyt c na presença (a) e na ausência (b) das NPs-Au. Com a presença das NPs-Au na interface criada após a imobilização do Cyt c em filmes automontados, obteve-se uma constante de transferência de elétrons quatro vezes maior quando comparado na ausência dessas NPs metálicas.......26

Figura 4- Imagem do aparato experimental empregado na síntese das $\mathrm{NPs}-\mathrm{Fe}_{3} \mathrm{O}_{4}$

Figura 5- Ilustração esquemática da obtenção das $\mathrm{NPs}-\mathrm{Fe}_{3} \mathrm{O}_{4}$ decoradas com NPs-Au por meio das modificações in situ (a) e ex situ (b)...

Figura 6- (a) Representação esquemática do controle magnético comutável da reação de transferência direta de elétrons do Cyt c empregando os modos switch on (lado esquerdo) e switch off (lado direito).

Figura 7- (a) Imagens de MET das $\mathrm{NPs}_{-} \mathrm{Fe}_{3} \mathrm{O}_{4}$. Em destaque, tem-se o padrão de difração de elétrons referente às $\mathrm{NPs}_{-} \mathrm{Fe}_{3} \mathrm{O}_{4}$. (b) Histograma e ajuste log-normal da distribuição de tamanho para as $\mathrm{NPs}-\mathrm{Fe}_{3} \mathrm{O}_{4}$

Figura 8- Espectros de UV-Vis da solução de $\mathrm{HAuCl}_{4} .3 \mathrm{H}_{2} \mathrm{O} 0,50 \mathrm{mmol} \mathrm{L}^{-1}$ (linha preta) e da suspensão de NPs-Au (linha vermelha). Em destaque, tem-se a imagem da solução $\mathrm{HAuCl}_{4} \cdot 3 \mathrm{H}_{2} \mathrm{O}$ (lado esquerdo), e das suspensões de NPs-Au antes (meio) e após a etapa de envelhecimento (lado direito). . .40

Figura 9- Imagem de MET das NPs-Au (a). Histograma e ajuste gaussiano para distribuição de tamanho das NPs-Au apresentando um diâmetro médio de aproximadamente $3,8 \mathrm{~nm}$ (b).

Figura 10- (a) Espectros de UV-Vis das NPs-Au obtidos 1 min após a adição do agente redutor ao meio de reação. Em destaque, observa-se o aumento dos valores de absorção máxima da banda plasmon e seu deslocamento para menores valores de energia em função do tempo. (b) Acompanhamento temporal referente ao crescimento das NPs-Au, no qual apresenta os valores de absorção máxima da banda plasmon observados nos espectros de UV-Vis na Figura 10a.

Figura 11- Difratogramas referentes às $\mathrm{NPs}^{-} \mathrm{Fe}_{3} \mathrm{O}_{4}$ antes (linha preta) e após as modificações in situ (linha azul) e ex situ (linha vermelha). Fichas cristalográficas JCPDS no. 19-629 e 01-1174 atribuídas aos padrões de magnetita (linhas verticais pretas) e ouro (linhas verticais vermelhas), respectivamente.

Figura 12- Imagens de MET ( $i$ e ii) e histogramas com ajuste log-normal (iii) para distribuição de tamanho referente às NPs-Au depositadas sobre as $\mathrm{NPs}-\mathrm{Fe}_{3} \mathrm{O}_{4}$ por meio das modificações in situ (a) e ex situ (b).

Figura 13- Imagens MET das NPs-Fe ${ }_{3} \mathrm{O}_{4}$-Au obtidas durante a análise de EDX (a). Espectro de EDX para a amostra de $\mathrm{NPs}_{\mathrm{F}}-\mathrm{Fe}_{3} \mathrm{O}_{4}-\mathrm{Au}(\mathrm{b})$.

Figura 14- (a) Espectros de UV-Vis das suspensões de $\mathrm{NPs}_{-}-\mathrm{Fe}_{3} \mathrm{O}_{4}$ (linha preta) e das $\mathrm{NPs}-\mathrm{Fe}_{3} \mathrm{O}_{4}-\mathrm{Au}$ (linha roxa). (b) Imagens da suspensão de $\mathrm{NPs}^{-} \mathrm{Fe}_{3} \mathrm{O}_{4}$ - $\mathrm{Au}$ antes (lado esquerdo) e após (lado direito) aplicação de um campo magnético externo. 
Figura 15- (a) Espectros de UV-Vis referentes à suspensão de $\mathrm{NPs}_{-} \mathrm{Fe}_{3} \mathrm{O}_{4}-\mathrm{Au}$ antes (i) e após (ii) o processo de decantação magnética $(B=0,2 \mathrm{~T})$. Em (b), tem-se a reprodutibilidade da banda plasmon em $530 \mathrm{~nm}$ após as $\mathrm{NPs}-\mathrm{Fe}_{3} \mathrm{O}_{4}-\mathrm{Au}$ terem sido primeiramente aglomeradas e, em seguida, sonicadas empregando um banho de ultrassom.

Figura 16- (a) Espectros de FTIR referentes às amostras de Cist (ii) e das $\mathrm{NPs}_{-}-\mathrm{Fe}_{3} \mathrm{O}_{4}$-Au antes (i) e após (iii) a etapa de funcionalização. (b) Ampliação da região em destaque na Figura 16a.

Figura 17- Espectro de FTIR referente à cistina comercial.

Figura 18- Espectros de FTIR referentes às nanopartículas de magnetita (a) e de ouro (b) modificadas com cisteína; e NPs- $\mathrm{Fe}_{3} \mathrm{O}_{4}$-Au funcionalizadas com grupos amino e carboxílicos (c).

Figura 19- Espectros de FTIR referentes às amostras de Cyt c (linha laranja) e do composto $\mathrm{NPs}-\mathrm{Fe}_{3} \mathrm{O}_{4}-\mathrm{Au}-\mathrm{Cyt} \mathrm{c}$ (linha preta).

Figure 20- Espectros de UV-Vis da solução de Cyt c $0,25 \mathrm{mg} \mathrm{mL}^{-1}$ preparada em tampão fosfato de sódio $50 \mathrm{mmol} \mathrm{L}^{-1}, \mathrm{pH}$ 7,0 (linha preta), do sobrenadante após a imobilização do Cyt c sobre as $\mathrm{NPs}_{-} \mathrm{Fe}_{3} \mathrm{O}_{4}-\mathrm{Au}$ funcionalizadas (linha azul) e da solução de Cyt c $0,25 \mathrm{mg} \mathrm{mL}^{-1}$ deixada sob agitação mecânica após 24 horas (linha amarela) à $22^{\circ} \mathrm{C}$. Em destaque, têm-se as imagens das soluções de Cyt c antes (a) e após (b) a etapa de imobilização utilizando GLU como agente de entrecruzamento. . .56

Figura 21- Espectros de UV-Vis obtidos para diferentes soluções padrão de Cyt c preparadas em tampão fosfato de sódio $50 \mathrm{mmol} \mathrm{L}^{-1}, \mathrm{pH} 7,0$. Em destaque, tem-se a curva de calibração obtida em $410 \mathrm{~nm}$ para as soluções de Cyt c com diferentes concentrações $\left(0,0078-0,25 \mathrm{mg} \mathrm{mL}^{-1}\right)$. Temperatura: $22^{\circ} \mathrm{C}$ . .56

Figura 22- Voltamogramas cíclicos obtidos para o eletrodo de ouro (linhas pontilhadas em a, b, c e d) e para os filmes magneticamente induzidos de $\mathrm{NPs}-\mathrm{Fe}_{3} \mathrm{O}_{4}$ (linhas pretas em a e d), $\mathrm{NPs}^{-} \mathrm{Fe}_{3} \mathrm{O}_{4}-\mathrm{Au}$ (linhas vermelhas em b e d) e NPs- $\mathrm{Fe}_{3} \mathrm{O}_{4}-\mathrm{Au}$ funcionalizadas (linhas azuis em c e d). Eletrólito suporte: tampão fosfato de sódio $50 \mathrm{mmol} \mathrm{L}^{-1}$, $\mathrm{pH} 7,0$. Velocidade de varredura: $100 \mathrm{mV} \mathrm{s}^{-1}$.

Figura 23- Diagrama de Pourbaix para o sistema ferro em água $\left(25^{\circ} \mathrm{C}, 1 \mathrm{~atm}\right)$. Para esse último, as únicas espécies consideradas em estado sólido são $\mathrm{Fe}, \mathrm{Fe}_{3} \mathrm{O}_{4} \mathrm{e} \gamma-\mathrm{Fe}_{2} \mathrm{O}_{3}$.

Figura 24- Voltamogramas cíclicos obtidos para o eletrodo de ouro (linha preta pontilhada), solução de Cyt c $0,25 \mathrm{mg} \mathrm{mL}^{-1}$ (linha roxa) e para o composto $\mathrm{NPs}-\mathrm{Fe}_{3} \mathrm{O}_{4}-\mathrm{Au}-\mathrm{Cyt}$ c quando aplicado o modo switch on (linha vermelha). Eletrólito suporte: tampão fosfato de sódio $50 \mathrm{mmol} \mathrm{L}^{-1}, \mathrm{pH} \mathrm{7,0}$. Velocidade de varredura: $100 \mathrm{mV} \mathrm{s}^{-1}$......

Figura 25- (a) Voltamogramas cíclicos em diferentes velocidades de varredura (50 - $1000 \mathrm{mV} \mathrm{s}^{-1}$ ) para o composto NPs- $\mathrm{Fe}_{3} \mathrm{O}_{4}-\mathrm{Au}$-Cyt c empregando o modo switch on. (b) Gráfico da variação da densidade de corrente dos picos anódicos $\left(j_{\mathrm{pa}}\right)$ e catódicos $\left(j_{\mathrm{pc}}\right)$ em função da raiz quadrada da velocidade. Eletrólito suporte: tampão fosfato de sódio $50 \mathrm{mmol} \mathrm{L}^{-1}, \mathrm{pH} 7,0$.

Figura 26- Controle magnético comutável da reação de transferência direta de elétrons do Cyt c empregando os dois estados comutativos, os modos switch on (linhas vermelha, verde, azul e cinza) e switch off (linhas pretas). À direta, os gráficos em destaque mostram o decaimento dos valores de $j_{\mathrm{pa}} \mathrm{e}$ $j_{\mathrm{pc}}$ após a permuta entre esses dois modos comutáveis (pontos vermelho, verde, azul e cinza). Eletrólito suporte: tampão fosfato de sódio $50 \mathrm{mmol} \mathrm{L}^{-1}, \mathrm{pH} \mathrm{7,0}$. Velocidade de varredura: $100 \mathrm{mV} \mathrm{s}^{-1}$...........

Figura 27- Aparato experimental utilizado na construção de padrões litográficos por meio das litografias magnéticas positiva e negativa. 
Figura 28- (a) Grade de cobre de 300 mesh utilizada como máscara litográfica para a obtenção dos padrões de litografia magnética sobre a superfície de um substrato sólido. (b) Imagem de microscopia óptica (obtida com uma objetiva de 15x) mostrando os espaços vazios na malha que compõe a máscara litográfica. Para esse último, cada espaço vazio originou um padrão com uma área aproximada de $3600 \mu \mathrm{m}^{2}$.

Figura 29- Ilustração esquemática da captura dos nanocages bimetálicos de $\mathrm{Au} / \mathrm{Ag}$ e preparo dos padrões de litografia magnética.

Figura 30- Imagens de MEV em (a) e (b) ilustram nanopartículas monodispersas de Ag com uma morfologia cúbica. Em (c), tem-se o histograma e ajuste gaussiano da distribuição de tamanho médio para a aresta dos nanocubos de $\mathrm{Ag}$ de aproximadamente $135,3 \mathrm{~nm}$. . .78

Figura 31- Ilustração esquemática da obtenção de nanaboxes e nanocages bimetálicos de $\mathrm{Au} / \mathrm{Ag}$ empregando a reação de substituição galvânica.

Figura 32- Imagens de MEV (a) e MET (b) dos nanoboxes bimetálicos de Au/Ag

Figura 33- Imagens de MET em (a) e (b) ilustram os nanocages de Au/Ag obtidos após a titulação de nanoboxes com $3 \mathrm{~mL}$ da solução de $\mathrm{HAuCl}_{4} 0,2 \mathrm{mmol} \mathrm{L}^{-1}$. Imagem de MET, em campo escuro, mostrando apenas um nanocages isolado (c). Mapeamento elementar (dot mapping) referente à nanoestrutura ilustrada em (c), destacando a presença dos principais elementos químicos que o constituem: ouro (d) e prata (e)...

Figura 34- Espectros de UV-Vis-NIR das suspensões de nanocubos de Ag (a), nanoboxes (b) e nanocages bimetálicos de $\mathrm{Au} / \mathrm{Ag}(\mathrm{c})$.

Figura 35- Esquema ilustrativo da captura dos nanocages bimetálicos de $\mathrm{Au} / \mathrm{Ag}$ em suspensão aquosa após aglomeração randômica com as $\mathrm{NPs}-\mathrm{Fe}_{3} \mathrm{O}_{4}$.

Figura 36- Imagens de MET dos aglomerados de nanocages bimetálicos de $\mathrm{Au} / \mathrm{Ag}$ e $\mathrm{NPs}-\mathrm{Fe}_{3} \mathrm{O}_{4}$ em filme de carbono.

Figura 37- Espectros de UV-Vis-NIR para a suspensão contendo a mistura de nanocages bimetálicos e $\mathrm{NPs}-\mathrm{Fe}_{3} \mathrm{O}_{4}$. Esses espectros foram obtidos na presença (a) e na ausência (b) de um campo magnético constante $(B=0,2 \mathrm{~T})$. (c) Monitoramento dos valores de extinção da banda de SPR em $1075 \mathrm{~nm}$ observados em (a) e (b). Em destaque, as imagens (1) e (2) ilustram o comportamento da suspensão de interesse quando aplicado um campo magnético nos tempos 0 e $2 \mathrm{~h}$. . .85

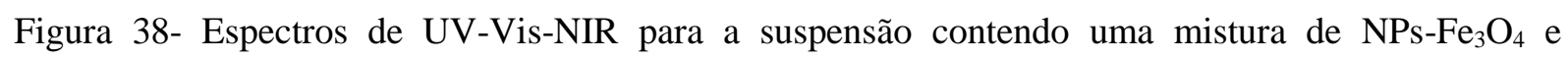
nanocages não remanescentes. Assim como na Figura 37, esses espectros foram obtidos na presença (a) e na ausência (b) de um campo magnético constante $(B=0,2 \mathrm{~T}$ ). (c) Monitoramento dos valores de extinção da banda de SPR em 1075 nm observados em (a) e (b).

Figura 39- Imagens de MEV dos padrões de litografia magnética sobre o substrato de ITO: as imagens observadas em (a) e (b) mostram a obtenção de padrões litográficos homogêneos com uma área aproximada de $3600 \mu \mathrm{m}^{2}$, enquanto as imagens em (c) e (d), referentes às áreas em destaque observadas em (a) e (b), respectivamente, mostram a diferença no perfil dos aglomerados de nanocages bimetálicos após deposição fora e sobre a malha que compõem a grade cobre utilizada como máscara litográfica...

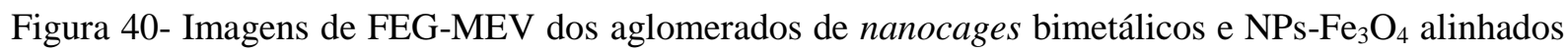
na forma de microfios sobre a superfície do substrato de ITO (a, b, c e d)... 
Figura 41- Imagens de FEG-MEV em (a) e (b) dos aglomerados mostrados na Figura 40d, evidenciando a tendência das $\mathrm{NPs}-\mathrm{Fe}_{3} \mathrm{O}_{4}$ (indicadas pelas setas amarelas) de se posicionarem na interface criada entre a superfície do ITO e os nanocages bimetálicos. (c) Ilustração esquemática da transferência, deposição e reorganização dos aglomerados de nanocages bimetálicos e $\mathrm{NPs}-\mathrm{Fe}_{3} \mathrm{O}_{4}$ sobre na superfície do substrato de ITO após aplicação de um campo magnético de valor constante.

Figura 42- Espectros de FTIR referentes às amostras de PVP (linha verde) e dos nanocages bimetálicos de $\mathrm{Au} / \mathrm{Ag}$ (linha azul). Em destaque, tem-se a representação da estrutura química da unidade de repetição do polímero PVP.

Figura 43- Representação esquemática da interação de PVP, na forma oligomérica, sobre os planos (111)

dos nanocages bimetálicos de $\mathrm{Au} / \mathrm{Ag}$..... .92

Figura 44- (a) Mapeamento químico dos padrões de litografia magnética em substrato de ITO. (b) Espectros de absorção (em modo reflectância difusa) coletados dentro (linha vermelha) e fora (linha preta) dos padrões litográficos, onde as suas posições estão indicadas no mapa químico em 1 e 2 , respectivamente. Para a construção do mapa químico observado em (a), integrou-se à área em destaque em (b) que compreende os modos vibracionais das moléculas de PVP presentes na superfície dos nanocages bimetálicos de $\mathrm{Au} / \mathrm{Ag}$. 


\section{Lista de tabelas}

Tabela 1 - Análise elementar das NPs- $\mathrm{Fe}_{3} \mathrm{O}_{4}$-Au empregando EDX.

Tabela 2- Atribuição das bandas nos espectros de FTIR referentes às amostras de Cist (ii) e das $\mathrm{NPs}-\mathrm{Fe}_{3} \mathrm{O}_{4}-\mathrm{Au}$ antes (i) e após (iii) a etapa de funcionalização.

Tabela 3- Atribuição das bandas nos espectros de FTIR referentes às amostras de Cyt $\mathrm{c}$ e do composto $\mathrm{NPs}-\mathrm{Fe}_{3} \mathrm{O}_{4}-\mathrm{Au}-\mathrm{Cyt} \mathrm{c}$

Tabela 4- Atribuição das bandas observadas nos espectros de FTIR referentes às amostras de PVP e dos nanocages bimetálicos com superfície modificada... 


\section{Lista de abreviaturas e siglas}

NPs. nanopartículas

NPMs nanopartículas magnéticas

$\mathrm{NPs}-\mathrm{Fe}_{3} \mathrm{O}_{4}$ nanopartículas de magnetita

NPs-Au. nanopartículas de ouro

$\mathrm{NPs}-\mathrm{Fe}_{3} \mathrm{O}_{4}-\mathrm{Au}$. .NPs- $\mathrm{Fe}_{3} \mathrm{O}_{4}$ decoradas com NPs-Au empregado a modificação ex situ

Cyt c citocromo c

GLU .glutaraldeído

Cist. cisteína

$\mathrm{FeCl}_{3} \cdot 6 \mathrm{H}_{2} \mathrm{O}$ cloreto férrico hexaidratado

$\mathrm{FeCl}_{2} .4 \mathrm{H}_{2} \mathrm{O}$ .cloreto ferroso tetraidratado

$\mathrm{HAuCl}_{4} .3 \mathrm{H}_{2} \mathrm{O}$. .ácido tetracloroaúrico triidratado

$\mathrm{NaOH}$ hidróxido de sódio

$\mathrm{HCl}$. ácido clorídrico

$\mathrm{BH}_{4} \mathrm{Na}$ borohidreto de sódio

$\mathrm{KBr}$ brometo de potássio

$\mathrm{KCl}$ cloreto de potássio

UV-Vis .espectroscopia na região do ultravioleta e visível

FTIR. espectroscopia na região do infravermelho com transformada de Fourier DRX difração de raios $X$

MET microscopia eletrônica de transmissão

MEV. microscopia eletrônica de varredura

MEV-FEG. microscopia eletrônica de varredura com emissão de campo PMMA polimetilmetacrilato VC. voltametria cíclica

ET. ..eletrodo de trabalho

ER eletrodo de referência

CE. ..contra eletrodo switch on...... modo ligado switch off. modo desligado $\mathrm{Ag} / \mathrm{AgCl}_{\text {sat }}$ .eletrodo de prata/cloreto de prata saturado em $\mathrm{KCl}$ hollow. do português, oco ou vazio shell. do português, casca nanocages do português, nanogaiolas 
nanoboxes ..do português, nanocaixas

template. do português, molde

SPR .ressonância de plasmon de superfície NPs-Ag. .nanopartículas de Ag

ITO. vidro recoberto com óxido de estanho dopado com índio $\mathrm{AgNO}_{3}$ .nitrato de prata

$\mathrm{CuCl}_{2} \cdot 2 \mathrm{H}_{2} \mathrm{O}$. cloreto de cobre (II) dihidratado

PD. 1,5-pentanodiol

PVP polivinilpirrolidona

$\mathrm{NaCl}$. ..cloreto de sódio

NIR. infravermelho próximo SPR. ..ressonância de plasmon de superfície EDX .espectrometria por dispersão de energia de raios $\mathrm{X}$ UV-Vis-NIR ..espectroscopia eletrônica na região do UV-Vis e infravermelho próximo 


\section{Lista de símbolos}

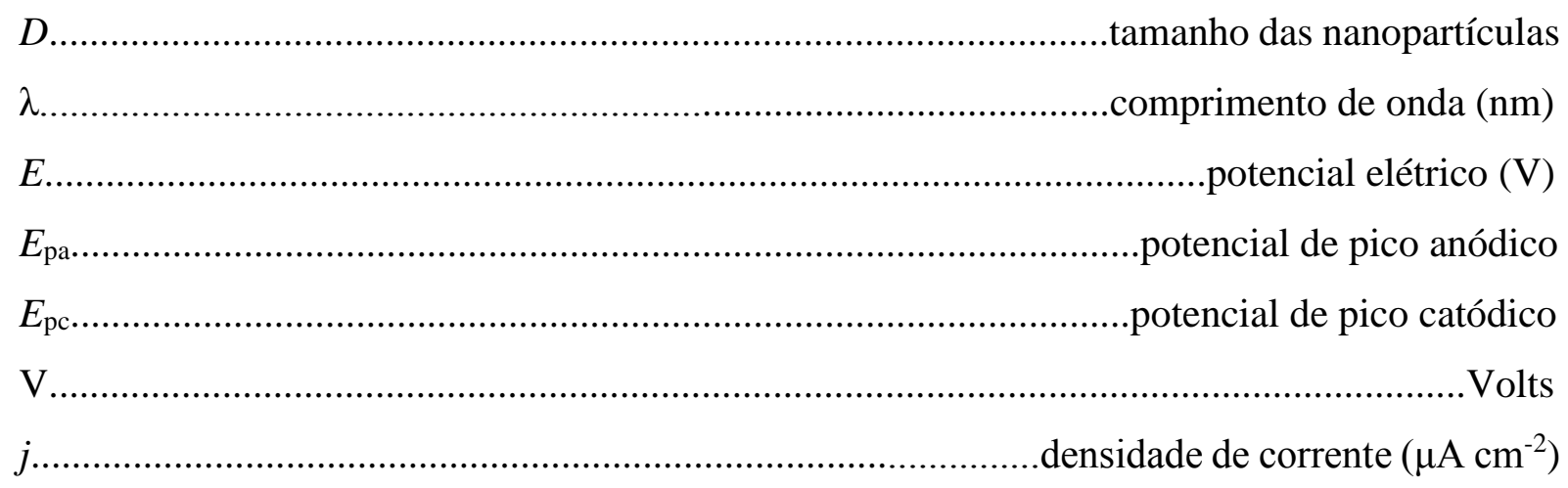

A. Ampere

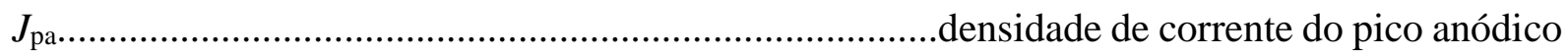

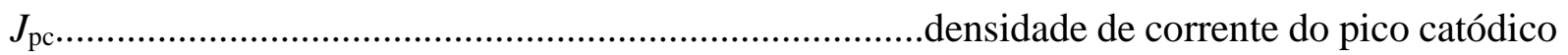

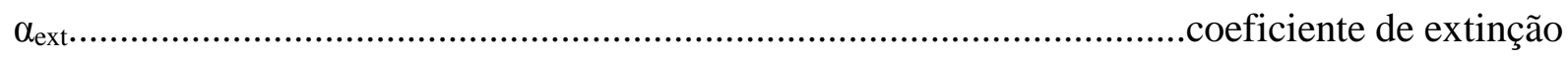

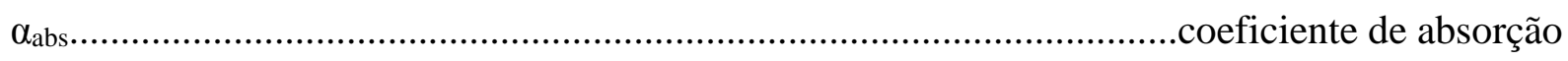

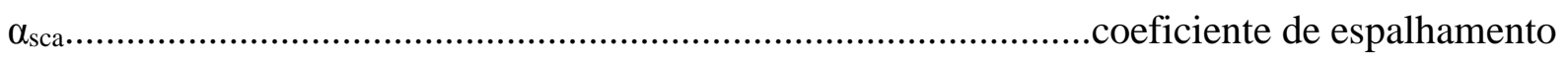

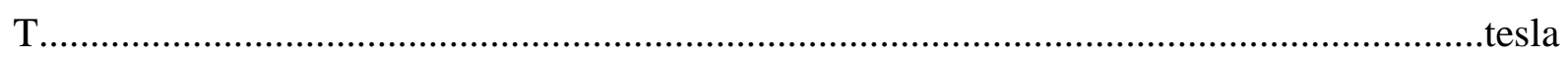




\section{Sumário}

Apresentação dos capítulos.

Capítulo I - Controle magnético comutável da reação de transferência direta de elétrons do citocromo c

1 Introdução

1.1 Considerações Gerais: Controle magnético comutável de reações redox e bioeletrocatalíticas.

1.2 Citocromo c

1.3 Reação de transferência direta de elétrons em enzimas e proteínas redox

1.4 Imobilização de enzimas e proteínas redox

1.5 Nanomateriais constituídos por NPs- $\mathrm{Fe}_{3} \mathrm{O}_{4}$ modificadas com NPs-Au

2 Objetivos

2.1 Metas

3 Procedimento experimental.

3.1 Reagentes.

3.2 Instrumentação

3.3 Síntese das NPs- $\mathrm{Fe}_{3} \mathrm{O}_{4}$

3.4 Síntese das NPs-Au

3.5 Obtenção das $\mathrm{NPs}-\mathrm{Fe}_{3} \mathrm{O}_{4}$ decoradas com NPs-Au.

3.6 Funcionalização das $\mathrm{NPs}_{-}-\mathrm{Fe}_{3} \mathrm{O}_{4}-\mathrm{Au}$ e imobilização do Cyt c.....

3.7 Controle magnético comutável da reação de transferência direta de elétrons do Cyt c......

4 Resultados e discussão

4.1 Síntese e caracterização das $\mathrm{NPs}-\mathrm{Fe}_{3} \mathrm{O}_{4}$

4.2 Síntese e caracterização das NPs-Au.

4.3 $\mathrm{NPs}^{-} \mathrm{Fe}_{3} \mathrm{O}_{4}$ decoradas com NPs-Au: modificação ex situ vs. modificação in situ.

4.4 Caracterização das $\mathrm{NPs}^{-\mathrm{Fe}_{3} \mathrm{O}_{4}}$ decoradas com NPs-Au via modificação ex situ. 
4.5 Funcionalização das $\mathrm{NPs}-\mathrm{Fe}_{3} \mathrm{O}_{4}$-Au utilizando grupos amino e carboxílicos.

4.6 Imobilização do Cyt c sobre as $\mathrm{NPs}_{-} \mathrm{Fe}_{3} \mathrm{O}_{4}-\mathrm{Au}$ funcionalizadas................................. $\quad \mathbf{5 3}$

4.7 Eletroquímica das $\mathrm{NPs}_{-} \mathrm{Fe}_{3} \mathrm{O}_{4}-\mathrm{Au}$ funcionalizadas................................................ $\quad 57$

4.8 Controle magnético comutável da reação de transferência direta de elétrons do Cyt c

5 Conclusão.

Capítulo II - Captura e transferência de nanocages bimetálicos para obtenção de padrões de litografia magnética.

1 Introdução

1.1 Considerações Gerais: Litografia Magnética.

1.2 Nanoestruturas metálicas hollow obtidas por substituição galvânica.

2 Objetivos

2.1 Metas

3 Procedimento experimental.

3.1 Instrumentação.

3.2 Síntese dos nanocubos de Ag.

3.3 Síntese de nanoboxes e nanocages de Au/Ag....

3.4 Captura dos nanocages bimetálicos e preparo dos padrões de litografia magnética

4 Resultados e discussão.

4.1 Síntese e caracterização dos nanocubos de Ag.

4.2 Síntese e caracterização dos nanoboxes e nanocages bimetálicos de $\mathrm{Au} / \mathrm{Ag}$.. 78

4.3 Captura e transferência dos nanocages bimetálicos de Au/Ag.....

4.4 Caracterização dos padrões de litografia magnética.

4.5 Modificação dos nanocages bimetálicos e mapeamento químico de infravermelho dos padrões de litografia magnética. 
Referências.

Anexo.

116

Trabalhos publicados durante o período do doutorado. 


\section{Apresentação dos capítulos}

Neste estudo, o primeiro capítulo descreve a obtenção, modificação e funcionalização de nanopartículas de magnetita $\left(\mathrm{NPs}-\mathrm{Fe}_{3} \mathrm{O}_{4}\right)$ para proporcionar um ambiente favorável para a imobilização do citocromo c (Cyt c); uma proteína redox de comportamento modelo dotada de um grupo prostético heme (porfirina de ferro) em sua estrutura terciária. Em seguida, após um efetivo processo de imobilização, o uso de um campo magnético externo possibilitou a deposição das $\mathrm{NPs}-\mathrm{Fe}_{3} \mathrm{O}_{4}$ modificadas com Cyt c sobre uma interface eletródica, estabelecendo a reação de transferência de elétrons entre o grupo prostético heme e a superfície de um eletrodo de trabalho (ET) de ouro. Portanto, para esse capítulo, o principal proposito foi a utilização de um campo magnético para obter o controle comutável da reação de transferência direta de elétrons do Cyt c quando imobilizado na superfície das $\mathrm{NPs}_{-}-\mathrm{Fe}_{3} \mathrm{O}_{4}$ modificadas.

Para o segundo e último capítulo, $\mathrm{NPs}-\mathrm{Fe}_{3} \mathrm{O}_{4}$ foram utilizadas pela primeira vez como adesivo magnético para capturar nanoestruturas metálicas hollow dispersas em suspensão. Por meio da influência de um campo magnético externo de valor constante, os aglomerados formados entre esses dois nanomateriais foram depositados sobre a malha que compõe máscara litográfica de cobre, levando a formação de padrões de litografia magnética dispostos sobre a superfície de um substrato de ITO (vidro recoberto com uma camada de índio dopada com estanho).

De acordo com os resultados alcançados, $\mathrm{NPs}_{-}-\mathrm{Fe}_{3} \mathrm{O}_{4}$ demonstram ser promissoras paras as duas aplicações propostas neste trabalho de doutorado. 


\section{CAPÍTULO I}

Controle magnético comutável da reação de transferência direta de elétrons do citocromo c 


\section{Introdução}

\subsection{Considerações gerais: Controle magnético comutável de reações redox e bioeletrocatalíticas}

O estudo da reação de transferência direta de elétrons entre proteínas redox e a superfície de eletrodos modificados tem recebido grande atenção da comunidade científica nos últimos anos. Isso é devido a sua potencial aplicação no desenvolvimento de biodispositivos pertencentes à nova geração, os quais requerem uma rápida e bem definida transferência de elétrons. ${ }^{1}$ Os primeiros relatos sobre a reação de transferência direta de elétrons entre proteína e eletrodo foram descritos, em 1977, em dois trabalhos desenvolvidos de forma independente. ${ }^{2,3}$ Nesses estudos, o citocromo c (Cyt c), sob controle difusional, apresentou uma resposta eletroquímica quase reversível sobre a superfície de dois tipos de eletrodos, ITO e ouro.

A partir desses dois estudos pioneiros, diversos outros trabalhos têm sido reportados, os quais demonstram o comportamento redox do Cyt c utilizando diferentes superfícies eletródicas como prata ${ }^{4}$ carbono,${ }^{5}$ platina,${ }^{6}$ entre outros. Mais recentemente, superfícies modificadas com materiais sensíveis a estímulos externos foram empregadas em estudos dessa natureza. Por exemplo, Katz e colaboradores ${ }^{7}$ demonstraram pela primeira vez o controle comutável da reação de transferência direta de elétrons do Cyt c sobre a superfície de um eletrodo de ouro modificado com uma monocamada composta por moléculas orgânicas fotossensíveis. Esse controle foi obtido por meio da incidência comutável de dois feixes de radiação ultravioleta, com diferentes comprimentos de onda, sobre a monocamada fotossensível depositada sobre a superfície eletródica.

Ao longo dos anos, Katz e colaboradores vêm abordando ao máximo a aplicação de superfícies sensíveis a estímulos externos voltados a obtenção do controle comutável de reações redox e bioeletrocatalíticas. ${ }^{8-10} \mathrm{O}$ primeiro relato, datado de 2002, descreve o deslocamento lateral de micropartículas de magnetita $\left(\mathrm{Fe}_{3} \mathrm{O}_{4}\right)$ modificadas com moléculas de DNA sobre uma superfície eletródica contendo duas áreas condutoras, denominadas de lados "direito" e "esquerdo". ${ }^{11}$ Ambos os lados correspondem a um eletrodo de trabalho, no qual foi aplicado um potencial de valor constante capaz de oxidar as bases guanina presentes nas moléculas de DNA. Dessa forma, movendo um ímã permanente abaixo da superfície eletródica, foi possível posicionar de forma comutativa as micropartículas de $\mathrm{Fe}_{3} \mathrm{O}_{4}$ modificadas com DNA sobre os lados "direito" e "esquerdo", levando a oxidação das bases guanina em ambos os lados 
separadamente. Posteriormente, utilizando um aparato experimental similar ao descrito no trabalho anterior, o deslocamento lateral de micropartículas de $\mathrm{Fe}_{3} \mathrm{O}_{4}$ modificadas com pirroloquinolina quinona (PQQ) sobre uma superfície de ouro foi utilizado para a oxidação da nicotinamida adenina dinucleotídeo (NADH) em locais previamente determinados. ${ }^{12}$ É sabido que moléculas de PQQ têm sido frequentemente utilizadas para oxidação do NADH (molécula orgânica com função de coezima), ${ }^{13}$ portanto, para esse estudo, a maior contribuição foi a demonstração do controle magnético comutável da reação eletroquímica em cascata envolvendo PQQ e NADH.

Em outro estudo de grande destaque desenvolvido por Kartz e colaboradores, ${ }^{14}$ nanopartículas de magnetita $\left(\mathrm{NPs}-\mathrm{Fe}_{3} \mathrm{O}_{4}\right)$ com um caráter hidrofóbico foram utilizadas a fim de obter, de forma comutável, a separação de dois processos redox observados simultaneamente sobre a superfície de um eletrodo de ouro (o processo controlado por difusão foi proveniente da reação de oxi-redução de um composto solúvel em fase aquosa derivado da quinona, enquanto o processo controlado por transporte de carga é oriundo do comportamento redox de moléculas de ferroceno empregadas na modificação da superfície do eletrodo de ouro), como ilustrado na Figura 1. Para isso, por meio da ação externa de um campo magnético, $\mathrm{NPs}^{-\mathrm{Fe}_{3} \mathrm{O}_{4}}$ hidrofóbicas foram primeiramente atraídas para a superfície eletródica, modo switch on, de modo que o processo eletroquímico difusional foi completamente inibido pela formação de um filme hidrofóbico sobre a superfície metálica. Por outro lado, quando empregado o modo switch off, as $\mathrm{NPs}_{-} \mathrm{Fe}_{3} \mathrm{O}_{4}$ hidrofóbicas foram retiradas da superfície eletródica, levando a observação de ambos os processos eletroquímicos.

Recentemente, no ano de 2013, dois estudos reportados por Crespilho e colaboradores ${ }^{15,16}$ demonstram um significativo avanço no controle magnético comutável de reações redox e bioeletrocatalíticas. O primeiro estudo reporta a modificação da superfície de micropartículas de $\mathrm{Fe}_{3} \mathrm{O}_{4}$ com quitosana e ferroceno insolúvel a fim de serem utilizadas como plataformas para imobilização da enzima glicose oxidase (GOx) após o uso do método de reticulação polimérica. Dessa forma, por meio da permuta entre os modos comutativos switch on e switch off, as micropartículas de $\mathrm{Fe}_{3} \mathrm{O}_{4}$ modificadas com a enzima GOx foram, respectivamente, posicionadas e retiradas da superfície do eletrodo de ITO, levando ao controle comutável da reação de oxidação de glicose catalisada por essa enzima redox. ${ }^{15}$ Já para o segundo estudo, uma única micropartícula de $\mathrm{Fe}_{3} \mathrm{O}_{4}$, com um tamanho de $120 \mu \mathrm{m}$, foi modificada com mediador redox azul da Prússia (PB) e, em seguida, inserida em uma gota de 
suporte eletrólito (com volume de $20 \mathrm{~mL}$ ) posicionada sobre a superfície de um eletrodo impresso de carbono. Nesse caso, a permutação entre os modos switch on e switch off permitiu o controle magnético comutável do processo de oxi-redução do PB sobre a superfície eletródica. Particularmente, esse estudo demonstra ser é extremante relevante, pois abre portas para futuras miniaturização de aparatos experimentais utilizados no controle magnético comutável de reações redox e bioeletrocatalíticas. ${ }^{16}$

Figura 1- Ilustração esquemática do controle magnético comutável da separação de dois processos redox observados simultaneamente sobre a superfície de um eletrodo de ouro; modos switch off (a) e switch on (b).

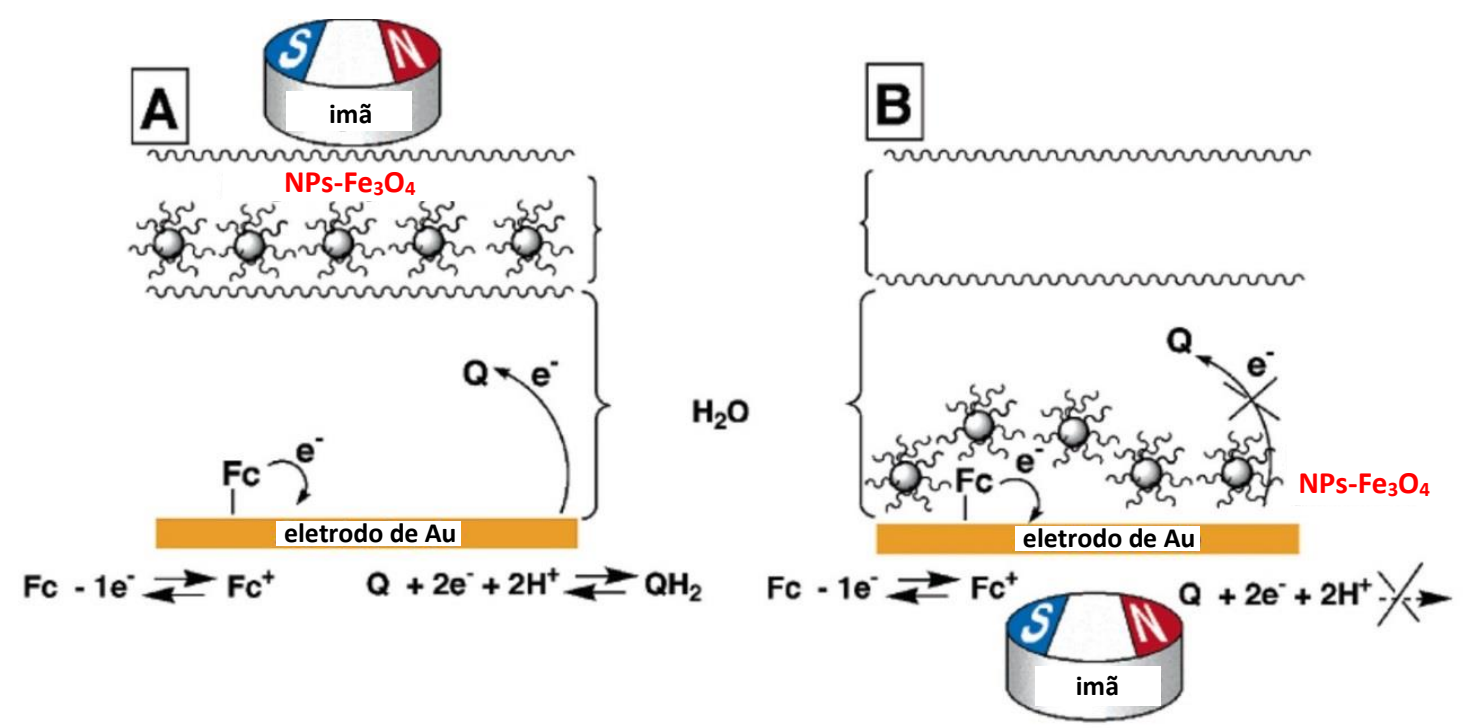

Fonte: Adaptação a partir de KATZ, E.; BARON, R.; WILLNER, I. Magnetoswitchable electrochemistry gated by alkyl-chain-functionalized magnetic nanoparticles: Control of diffusional and surface-confined electrochemical processes. Journal of the American Chemical Society, v. 127, n. 11, p. 4060-4070, 2005.

Nesse contexto, empregando os dois estados comutáveis, os modos switch on e switch off, a primeira parte deste trabalho tem como principal motivação a obtenção do controle magnético comutável da reação de transferência direta de elétrons do Cyt c sobre a superfície de um eletrodo de ouro. Para a realização da meta acima estabelecida, torna-se necessária a utilização de $\mathrm{NPs}-\mathrm{Fe}_{3} \mathrm{O}_{4}$ decoradas com nanopartículas de ouro ( $\mathrm{NPs}-\mathrm{Fe}_{3} \mathrm{O}_{4}-\mathrm{Au}$ ), nas quais foram empregadas como plataforma para a imobilização do Cyt c. Dessa forma, quando aplicado o modo switch on, o Cyt c imobilizado nas $\mathrm{NPs}_{-}-\mathrm{Fe}_{3} \mathrm{O}_{4}-\mathrm{Au}$ será depositado sobre a superfície eletródica, na forma de um filme protéico, permitindo a transferência direta de elétrons oriundos do grupo prostético heme até a superfície metálica do eletrodo de trabalho. 


\subsection{Citocromo c}

Cyt c é uma heme proteína solúvel em água que está presente entre as membranas interna e externa das mitocôndrias. ${ }^{17,18}$ A sua principal função é de transportador de elétrons entre os complexos III (citocromo c redutase) e IV (citocromo c oxidase) na cadeia de transporte mitocondrial. ${ }^{19}$ Ademais, outras funcionalidades têm sido estabelecidas, como a de sensor de estresse oxidativo e de componente de uma das vias de sinalização de apoptose. ${ }^{20}$

Em termos de estrutura em estado cristalino, o Cyt c possui uma boa caracterização, apresentando um formato globular, quase esférico, com diâmetro de $34 \AA^{21,23}$ Apesar de ser considerada uma proteína redox relativamente simples (proteína modelo), em sua estrutura primária é encontrada uma sequência de 104 aminoácidos que se enovelam em um arranjo tridimensional envolvendo o seu centro redox, o grupo prostético heme. Outra característica dessa proteína é a alta presença de resíduos básicos, sendo a grande maioria resíduos de lisina, histidina e arginina, o que a torna carregada positivamente em $\mathrm{pH}$ fisiológico devido à presença de oito cargas não compensadas. ${ }^{24,25}$ Esses resíduos encontram-se posicionados de forma adjacente ao local onde o grupo heme é mais exposto à superfície protéica.

No Cyt c, o centro redox conhecido como grupo prostético heme está ligado covalentemente a sua estrutura terciária por meio de pontes tioéter com dois resíduos de cisteínas nas posições 14 e 17 (Cys14 e Cys17). Esse grupo é constituído de quatro anéis de cinco átomos, contendo nitrogênio em uma estrutura cíclica chamada de porfirina, como apresenta a Figura 2. Os quatro átomos de nitrogênio estão coordenados a um átomo de ferro central que pode apresentar uma forma oxidada $\left(\mathrm{Fe}^{3+}\right)$ ou reduzida $\left(\mathrm{Fe}^{2+}\right)$. Além das quatro ligações do ferro com os átomos de nitrogênio dos anéis pirrólicos, são observadas uma quinta e a uma sexta coordenação, resultantes da ligação covalente axial (fora do plano do grupo heme) com um átomo de nitrogênio de uma histidina e um átomo de enxofre de uma metiodina, ambos nas posições 18 e 80 (His18 e Met80), respectivamente. Esses dois átomos são considerados ligantes de campo forte, mantendo o átomo de ferro em um estado de baixo spin, ou seja, na sua forma oxidada $\left(\mathrm{Fe}^{3+}\right)$. 
Figura 2- (a) Representação cristalográfica do Cyt c (PDB: 3CYT); (b) Visão frontal do grupo prostético heme demostrando um átomo de ferro (em laranja) coordenado a quatro átomos de nitrogênio (em azul) em uma estrutura denominada porfirina.
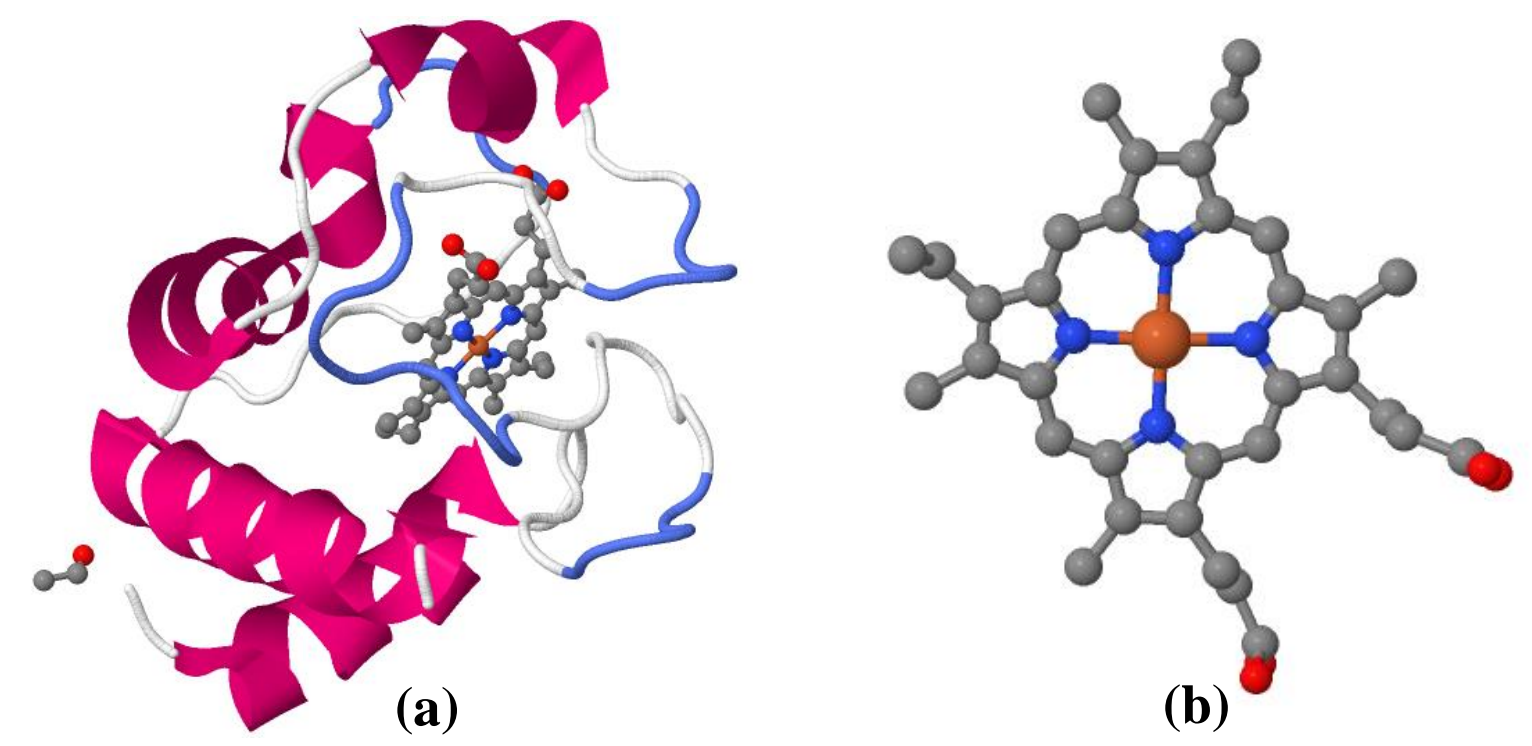

Fonte: RCSB PDB Jmol (Protein Data Bank), número de identificação 3CYT.

A sexta coordenação do átomo de ferro, Fe-S (Met80), não é considerada particularmente uma ligação estável, uma vez que o enfraquecimento dessa ligação constitui o mecanismo chave para a transição entre os estados de spin baixo e spin alto do átomo de ferro presente no grupo heme. ${ }^{26,27}$ Quando ocorre a perda da ligação do ferro hemínico com a metionina 80, um pequeno domínio da sequência de resíduos de aminoácidos nas posições 78 e 90 move-se, afastando-se do grupo heme. Esse movimento usualmente ocasiona uma abertura da estrutura protéica do Cyt c e uma consequente exposição do grupo heme, facilitando o transporte de elétrons.

Todas essas ligações descritas acima são de extrema importância em estudos eletroquímicos que envolvem a transferência direta de elétrons, pois as suas rupturas podem ocasionar mudanças na conformação estrutural do Cyt c, proporcionando a sua desnaturação e a perda da sua função redox. ${ }^{28}$ Além disso, o grupo prostético heme não se encontra totalmente recoberto pela sequência de aminoácidos. Dessa forma, a resposta redox desse grupo pode ser facilmente monitorada empregando técnicas espectroscópicas e/ou eletroquímicas. 


\subsection{Reação de transferência direta de elétrons em enzimas e proteínas redox}

As primeiras publicações sobre a reação de transferência direta de elétrons empregando proteínas redox são datadas de 1977 . Nesse ano, Yeh e Kuwana ${ }^{2}$ reportaram um comportamento eletroquímico quase reversível do Cyt c (pequena proteína redox ativa na transferência de elétrons em processos biológicos, mas que não apresenta propriedades enzimáticas) sobre a superfície de um eletrodo de ITO. Também nesse mesmo ano, mas de forma independente, Eddowes e $\mathrm{Hill}^{3}$ demonstraram um comportamento similar empregando um eletrodo de ouro modificado com uma monocamada do reagente 4,4'-bipiridilo. Após a realização desses trabalhos, outros estudos mencionam que a transferência direta de elétrons também é possível para grandes proteínas com características enzimáticas. ${ }^{1}$

Ao longo dos anos, inúmeros estudos eletroquímicos têm sidos realizados a fim de compreender esse fenômeno, contribuindo para a elucidação de mecanismos de transporte de carga entre biomoléculas redox presentes em sistemas biológicos. Atualmente, a grande maioria desses estudos baseia-se na teoria de Marcus. ${ }^{29,30}$ Embora essa teoria tenha sido desenvolvida para aplicações em sistemas em que predominam a transferência homogênea de elétrons, foi comprovado por meio de formalismo matemático que essa pode ser igualmente aplicada a processos de transferência heterogênea de elétrons entre uma proteína redox e uma determinada superfície eletródica. Em um desses estudos reportado recentemente, Luz e colaboradores ${ }^{31}$ demonstraram a reação de transferência direta de elétrons do Cyt c na presença de nanopartículas de ouro (NPs-Au), nas quais encontravam-se posicionadas na interface criada após a imobilização dessa proteína redox sobre filmes automontados. Nesse estudo, afim de determinar as constantes de transferência de elétrons, utilizou-se uma relação descrita Chidsey, ${ }^{32}$ obtida a partir da integração da equação padrão de Marcus em combinação com a distribuição de Fermi-Dirac. Como resultado, na presença das NPs-Au, observou-se um aumento significativo nos valores das constantes de transferência de elétrons do Cyt c quando comparado na ausência das NPs metálicas (Figura 3). 
Figura 3- Ilustração esquemática demonstrando a diferença nos valores das constantes de transferência de elétrons do Cyt c na presença (a) e na ausência (b) das NPs-Au. Com a presença das NPs-Au na interface criada após a imobilização do Cyt c em filmes automontados, obteve-se uma constante de transferência de elétrons quatro vezes maior quando comparado na ausência dessas NPs metálicas.

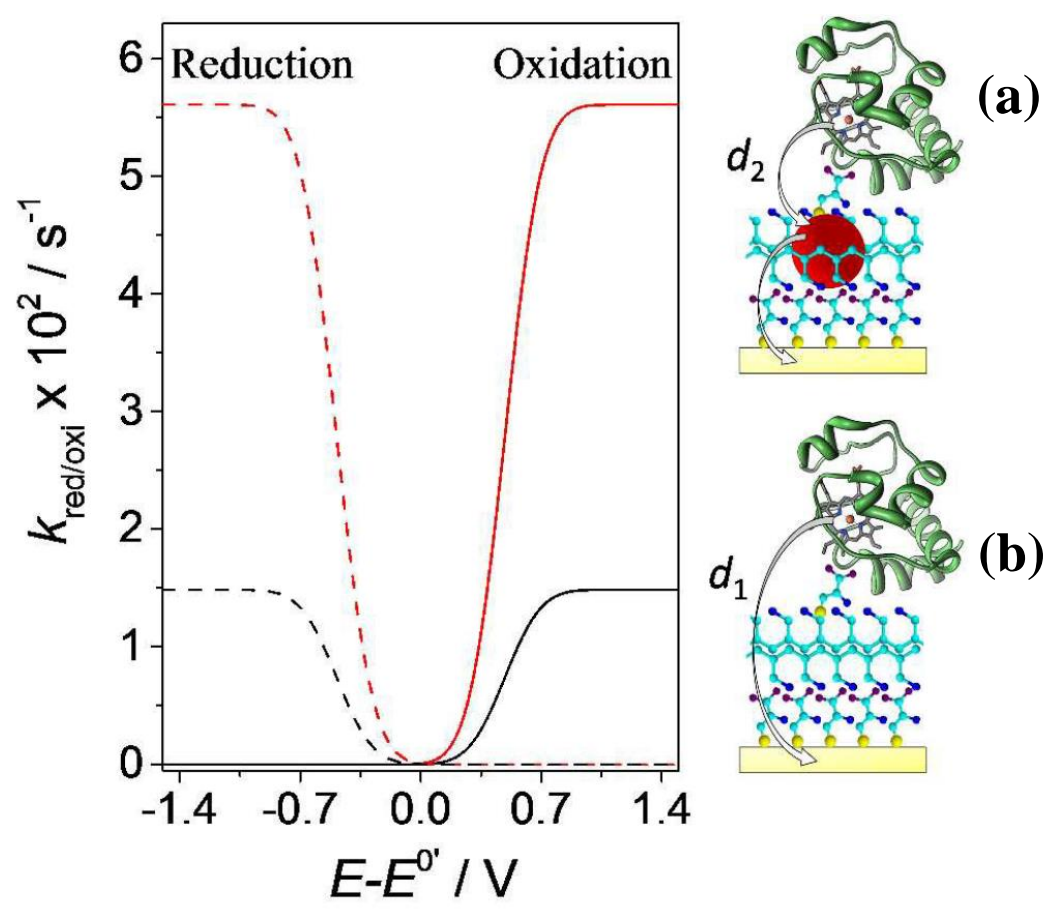

Fonte: LUZ, R. A.; CRESPILHO, F. N. Gold nanoparticle-mediated electron transfer of cytochrome c on a self-assembled surface. RSC Advances, v. 6, n. 67, p. 62585-62593, 2016.

É importante mencionar que a reação de transferência direta de elétrons envolvendo proteínas redox está diretamente relacionada à orientação dessa biomolécula sobre a superfície eletródica, pois na maioria das vezes os seus centros redox estão posicionados a uma longa distância, dificultando ou impossibilitando o processo de transferência direta de elétrons. Para esse último, a diminuição dessa distância pode ser alcançada quando enzima ou proteínas redox são imobilizadas efetivamente sobre a superfície de eletrodos modificados.

\subsection{Imobilização de enzimas e proteínas redox}

O processo efetivo de imobilização de enzimas e proteínas redox sobre uma determinada superfície eletródica é de fundamental importância para o bom desempenho no processo de transferência direta de elétrons, fazendo com que essas biomoléculas apresentem estabilidade e eficiência semelhante quando comparado em seu ambiente natural. Na literatura, têm-se vários métodos para a imobilização de enzimas e proteínas redox sobre a superfície de substratos 
sólidos. Cada uma dessas metodologias apresenta vantagens e desvantagens, dessa maneira, para a escolha correta de um determinado método, devem ser levados em consideração vários fatores, como solubilidade, estabilidade, temperatura e aplicabilidade dessa biomolécula, além da natureza da superfície do substrato. ${ }^{33}$

Atualmente, os métodos de imobilização mais empregados se baseiam nos fenômenos de adsorção química ou física entre o substrato e a biomolécula. ${ }^{34,35} \mathrm{~A}$ imobilização por adsorção física é um método simples, rápido e de baixo custo e os mecanismos de adsorção são baseados em ligações fracas, tais como interações de van der Waals, interações eletrostáticas (ou iônicas), dipolo-dipolo, ligações de hidrogênio, entre outras. Proteínas redox fisicamente adsorvidas exibem frequentemente uma excelente estabilidade, contudo, estão sujeitas à lixiviação, bem como a possíveis barreiras difusionais que podem prejudicar o processo de transferência direta de elétrons. ${ }^{33}$ Outra ramificação desse método é denominada de oclusão, sendo definida como a retenção física de biomoléculas em espaços intersticiais em uma superfície com características mesoporosas. ${ }^{36}$

Dentre os métodos que envolvem adsorção química, ou seja, a formação de ligações covalentes entre o substrato e as biomoléculas, a reação de reticulação (cross-linking) tem sido uma das metodologias mais utilizadas. ${ }^{37}$ Este tipo de imobilização ocorre a partir da interação de grupos não funcionais da proteína (parte não essencial para a atividade redox) com grupos reativos do material suporte, por exemplo, hidroxilas, carbonilas, aminas, fenólicos, imidazólicos e tióis. A ativação desses grupos é realizada geralmente com a utilização de reagentes multifuncionais como o glutaraldeído (GLU), carbodiimida, epicloridina, glioxal, amonotióis, entre outros. Esse método apresenta inúmeras vantagens, como uma forte ligação entre a proteína redox e o material suporte, além de uma menor susceptibilidade a problemas relacionados a variações de $\mathrm{pH}$, solvente e temperatura. A principal desvantagem dessa imobilização está relacionada a um possível estresse na proteína redox, podendo ocasionar alterações conformacionais em sua estrutura protéica, resultando na diminuição ou total perda da sua funcionalidade. ${ }^{33,36,38,39}$

Nos últimos anos, nanomateriais têm sido intensamente utilizados como plataformas para a imobilização de proteínas redox, pois promovem um ambiente favorável para imobilização dessas biomoléculas. O emprego de proteínas redox imobilizadas na superfície de nanomateriais voltado à construção de biossensores tem resultado em grandes avanços em termos de estabilidade e sensibilidade desses dispositivos analíticos, pois a sua utilização 
facilita o acesso aos centros redox, melhorando consideravelmente o processo de transferência direta de elétrons na superfície eletródica. ${ }^{33,38}$

\subsection{Nanomateriais constituídos por $\mathrm{NPs}_{\mathrm{S}} \mathrm{Fe}_{3} \mathrm{O}_{4}$ modificadas com NPs-Au}

Nanopartículas magnéticas (NPMs) constituem uma classe de nanomateriais cujo tamanho influencia diretamente em suas principais propriedades, tais como temperatura de ordenamento, magnetização de saturação, entre outras. Além dessas, outra propriedade surge em escala nanométrica, como exemplo pode ser citado o superparamagnetismo. ${ }^{40,41}$ Essa propriedade ocorre em nanopartículas (NPs) que possuem um único domínio magnético, ou seja, a magnetização de uma determinada nanopartícula é considerada um único momento magnético, o qual é representado pela soma de todos os momentos magnéticos individuais presentes em cada átomo que a constitui. ${ }^{41,42}$ Essa propriedade confere às NPMs grande facilidade de isolamento e separação de meios multifásicos complexos pelo simples uso de um ímã permanente, e sua fácil redispersão após cessada a aplicação do campo.

Atualmente, as NPMs têm sido sintetizadas com diferentes composições e fases cristalinas, as quais incluem os óxidos de ferro como a magnetita $\left(\mathrm{Fe}_{3} \mathrm{O}_{4}\right)^{43,44}$ e a maghemita $\left(\gamma-\mathrm{Fe}_{2} \mathrm{O}_{3}\right),{ }^{45}$ metais puros de $\mathrm{Co},{ }^{46}$ materiais ferromagnéticos do tipo espinélio $\left(\mathrm{FeFe}_{2} \mathrm{O}_{4}\right.$, $\mathrm{CoFe}_{2} \mathrm{O}_{4}$ e $\left.\mathrm{MnFe}_{2} \mathrm{O}_{4}\right),{ }^{47}$ e também ligas metálicas de $\mathrm{CoPt}_{3}{ }^{48} \mathrm{e} \mathrm{FePt}^{49-51}$ Dentre todas às NPMs citadas, $\mathrm{NPs}-\mathrm{Fe}_{3} \mathrm{O}_{4}$ vêm ganhando maior destaque devido a sua fácil obtenção e baixa toxicidade. $^{52,53}$

As NPs- $\mathrm{Fe}_{3} \mathrm{O}_{4}$ são óxidos de ferro pertencentes à família das ferritas. Geralmente, essa classe de material é representada pela fórmula química $\mathrm{M}^{2+} \mathrm{Fe}_{2}{ }^{3+} \mathrm{O}_{4}$, no qual " $\mathrm{M}$ " se refere ao íon metálico com estado de oxidação (II) oriundo do quarto período da tabela periódica

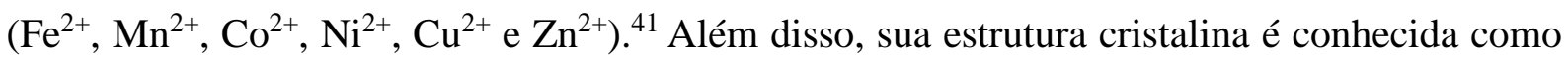
espinélio inverso, possuindo um empacotamento de íons de oxigênio em uma estrutura cúbica de face centrada com a presença de íons de ferro nos estados de oxidação (II) e (III) ${ }^{41,54}$ Devido ao seu tamanho diminuto observado em nanoescala (entre 3 a $30 \mathrm{~nm}$ ), as $\mathrm{NPs}-\mathrm{Fe}_{3} \mathrm{O}_{4}$ apresentam um volume total que corresponde a um único domínio magnético, o que proporciona uma elevada magnetização de saturação (30-50 emu/g). ${ }^{55}$ Além disso, apresentam uma elevada temperatura de Curie (Tc) e susceptibilidade magnética, ${ }^{56}$ o que as tornam candidatas ideais para aplicações em dispositivo de armazenamento em microeletrônica, catálise, gravadores 
magnéticos de alta densidade, refrigeração magnética, entre outros. ${ }^{57,58}$ Ademais, outras aplicações vêm se destacando como a magneto-hipertermia, ${ }^{59,60}$ liberação controlada de fármacos, ${ }^{61,63}$ agente de contraste em imagens de ressonância magnética, ${ }^{64,65}$ imobilização de enzimas e proteínas, ${ }^{66}$ biossensores,${ }^{67}$ separação e purificação de células e biomoléculas, ${ }^{68}$ detecção de DNA ${ }^{69}$ e ferrofluidos. ${ }^{70,71}$

Geralmente, para que as $\mathrm{NPs}-\mathrm{Fe}_{3} \mathrm{O}_{4}$ possam ser aplicadas, é necessária que apresentem uma boa estabilidade em suspensão coloidal. Para isso, deve-se evitar a formação de grandes agregados empregando um revestimento adequado de sua superfície. Outra limitação é presença de íons $\mathrm{Fe}^{2+}$ em sua estrutura cristalina que são facilmente oxidados em uma atmosfera não inerte. Portanto, a modificação da superfície das $\mathrm{NPs}-\mathrm{Fe}_{3} \mathrm{O}_{4}$ com NPs-Au oferece proteção contra a oxidação dos íons $\mathrm{Fe}^{2+}$ e estabilização do seu núcleo magnético, permitindo combinar as propriedades intrínsecas dessas duas classes de materiais. Além disso, as propriedades ópticas, elétricas e magnéticas das $\mathrm{NPs}_{-} \mathrm{Fe}_{3} \mathrm{O}_{4}$ modificadas com NPs-Au podem ser controladas por meio da morfologia empregada em seu revestimento metálico, que geralmente é obtido por meio da redução de íons de ouro sobre a superfície dos núcleos magnéticos utilizando um agente redutor externo.

$\mathrm{Na}$ literatura são reportados dois tipos de revestimentos metálicos, por exemplo, NPs decoradas ${ }^{72,73}$ e NPs do tipo core-shell. ${ }^{74,75}$ Para esse último, o shell deve ser obtido com uma espessura suficientemente fina a fim de não induzir alteração nas propriedades magnéticas do núcleo das $\mathrm{NPs}_{-} \mathrm{Fe}_{3} \mathrm{O}_{4}$. Geralmente, as metodologias utilizadas para a obtenção desses dois revestimentos metálicos incluem a utilização de solventes tóxicos e a geração de resíduos nocivos para saúde e meio ambiente, além de resultar em um alto consumo de energia em rotas geralmente complexas e com múltiplos passos. ${ }^{76,88}$ Além disso, para a imobilização de biomoléculas, por exemplo, enzimas e proteínas redox, geralmente são empregadas etapas de modificação de superfície utilizando procedimentos sintéticos que, na maioria das vezes, se tornam inviáveis para aplicações em meio fisiológico. Neste trabalho, diferentemente dos estudos que têm sido reportados, obtiveram-se $\mathrm{NPs}_{-}-\mathrm{Fe}_{3} \mathrm{O}_{4}$ decoradas com NPs-Au utilizando uma metodologia livre de solvente orgânico e sem a presença de polieletrólitos ou moléculas de surfactantes durante qualquer etapa de síntese. Mais detalhes sobre a metodologia empregada na obtenção das $\mathrm{NPs}^{-} \mathrm{Fe}_{3} \mathrm{O}_{4}$ decoradas com NPs-Au estão descritas no procedimento experimental. 


\section{Objetivos}

O principal objetivo deste estudo é a obtenção do controle magnético comutável da reação de transferência direta de elétrons do Cyt c sobre a superfície de um eletrodo de ouro. Para isso, propõe-se a utilização de $\mathrm{NPs}-\mathrm{Fe}_{3} \mathrm{O}_{4}$ decoradas com NPs-Au, nas quais são empregadas como uma plataforma para a imobilização do Cyt c.

\subsection{Metas}

Abaixo estão descritas as principais metas alcançadas para a realização do objetivo aqui apresentado:

1) Sintetizar e caracterizar NPs-Fe ${ }_{3} \mathrm{O}_{4}$ obtidas pelo método de coprecipitação;

2) Sintetizar e caracterizar NPs-Au obtidas por meio da adaptação do método de Brust;

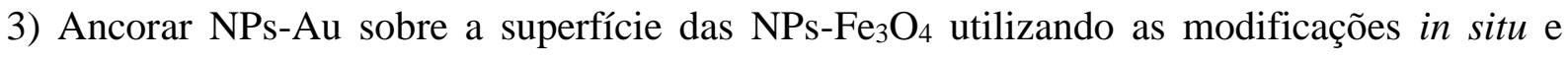
ex situ;

4) Funcionalizar as NPs-Fe ${ }_{3} \mathrm{O}_{4}$ decoradas com NPs- $\mathrm{Au}\left(\mathrm{NPs}-\mathrm{Fe}_{3} \mathrm{O}_{4}-\mathrm{Au}\right.$ ) como grupos amino e carboxílicos após a modificação de sua superfície utilizando moléculas de cisteína;

5) Imobilizar a proteína Cyt c sobre as $\mathrm{NPs}-\mathrm{Fe}_{3} \mathrm{O}_{4}-\mathrm{Au}$ funcionalizadas utilizando o método de reticulação polimérica (NPs-Fe $\left.\mathrm{O}_{4}-\mathrm{Au}-\mathrm{Cyt} \mathrm{c}\right)$;

6) Empregar os modos comutáveis switch on e switch off para posicionar e retirar, respectivamente, o composto $\mathrm{NPs}_{-} \mathrm{Fe}_{3} \mathrm{O}_{4}-\mathrm{Au}-\mathrm{Cyt}$ c da superfície eletródica, levando ao controle magnético comutável da reação de transferência direta de elétrons do Cyt c. 


\section{Procedimento experimental}

\subsection{Reagentes}

Cloreto férrico hexaidratado $99 \%\left(\mathrm{FeCl}_{3} \cdot 6 \mathrm{H}_{2} \mathrm{O}\right)$, cloreto ferroso tetraidratado $99 \%$ $\left(\mathrm{FeCl}_{2} .4 \mathrm{H}_{2} \mathrm{O}\right)$, ácido tetracloroaúrico triidratado $99 \%\left(\mathrm{HAuCl}_{4} .3 \mathrm{H}_{2} \mathrm{O}\right)$, hidróxido de sódio $98 \%$ $(\mathrm{NaOH})$, ácido clorídrico $37 \%(\mathrm{HCl})$, boroidreto de sódio $98 \%\left(\mathrm{NaBH}_{4}\right)$, brometo de potássio 99\% (KBr), L-cisteína (Cist), glutaraldeído (GLU) e citocromo c (Cyt c) de coração bovino $(\mathrm{PM}=12,327 \mathrm{kDa})$ foram adquiridos da Sigma-Aldrich, enquanto o fosfato de sódio monobásico $\left(\mathrm{NaH}_{2} \mathrm{PO}_{4} \cdot \mathrm{H}_{2} \mathrm{O}\right)$ e o fosfato de sódio bibásico $\left(\mathrm{Na}_{2} \mathrm{HPO}_{4}\right)$, utilizados na preparação do tampão fosfato de sódio $50 \mathrm{mmol} \mathrm{L}^{-1}$, foram adquiridos da Vetec. A partir desses reagentes descritos acima com um alto grau de pureza e água ultrapura (Milli-Q 18,2 $\mathrm{M} \Omega \mathrm{cm}$ ), prepararam-se todas as soluções utilizadas neste estudo.

\subsection{Instrumentação}

Os espectros de UV-Vis foram obtidos por meio de um espectrofotômetro Jasco V670 de duplo feixe, empregando uma cubeta de quartzo com um caminho óptico de $1 \mathrm{~cm}$, enquanto os difratogramas foram coletados em um difratômetro Rigaku, modelo Rint 2000, empregando radiação de cobre $(\lambda=0,15406 \mathrm{~nm})$, voltagem de $40 \mathrm{kV}$ e amperagem de $30 \mathrm{~mA}$. Para esse último, empregou-se um ângulo de varredura, em um intervalo de $30^{\circ} \leq 2 \theta \leq 100^{\circ}$, com passos de $0,05^{\circ}$ medidos a cada 5 segundos. Os espectros de FTIR foram obtidos no modo transmitância (janela de KBr) utilizando um espectrômetro Bruker Tensor 27 FT-IR, na região de 4000-400 $\mathrm{cm}^{-1}$, e resolução de $4 \mathrm{~cm}^{-1}$. As imagens de MET foram realizadas empregando um microscópio FEI Tecnai G2 F20 operado a $200 \mathrm{kV}$, enquanto as imagens de MEV foram obtidas em um microscópio FEI Magellan $400 \mathrm{~L}$ de alta resolução operado a $2,0 \mathrm{kV}$. A determinação do tamanho médio de aresta e o diâmetro de todas as nanopartículas empregadas neste estudo foi realizada após a contagem de 100 partículas cúbicas e esféricas, respectivamente. Para isso, utilizou-se o software de domínio público Image J. Por fim, os voltamogramas cíclicos obtidos durante o controle magnético comutável da reação transferência direta de elétrons do Cyt c foram coletados utilizando um potenciostato/galvanostato Autolab PGSTAT 128N acoplado a uma cela eletroquímica convencional com três eletrodos. 


\subsection{Síntese das $\mathrm{NPs}_{3}-\mathrm{Fe}_{3} \mathrm{O}_{4}$}

$\mathrm{NPs}-\mathrm{Fe}_{3} \mathrm{O}_{4}$ foram sintetizadas pelo método de coprecipitação, conforme descrito na literatura. ${ }^{89}$ Para isso, $\mathrm{FeCl}_{3} \cdot 6 \mathrm{H}_{2} \mathrm{O}(5,4 \mathrm{~g})$ e $\mathrm{FeCl}_{2} \cdot 4 \mathrm{H}_{2} \mathrm{O}(2,0 \mathrm{~g})$ foram dissolvidos em $25 \mathrm{~mL}$ de uma solução de $\mathrm{HCl} 10 \mathrm{mmol} \mathrm{L}^{-1}$. Depois, sob uma atmosfera de $\mathrm{N}_{2}, 250 \mathrm{~mL}$ de $\mathrm{NaOH}$ 1,5 mol L $\mathrm{L}^{-1}$ foram adicionados lentamente ao meio de reação (mantido sob agitação de $20 \mathrm{rpm}$ a uma temperatura de $80{ }^{\circ} \mathrm{C}$ ), levando a formação das $\mathrm{NPs}_{-} \mathrm{Fe}_{3} \mathrm{O}_{4}$ em suspensão aquosa. Em seguida, todas as $\mathrm{NPs}-\mathrm{Fe}_{3} \mathrm{O}_{4}$ presentes em suspensão foram decantadas por separação magnética e depois lavadas várias vezes com água ultrapura até $\mathrm{pH}$ 6,4. Por fim, as $\mathrm{NPs}_{-}-\mathrm{Fe}_{3} \mathrm{O}_{4}$ foram

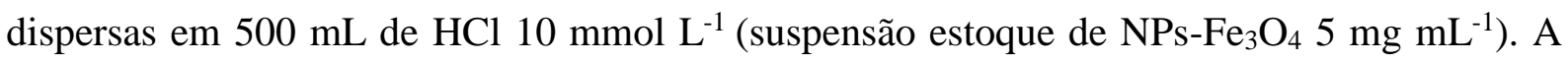
Figura 4 apresenta o aparato experimental empregado na síntese das $\mathrm{NPs}^{-} \mathrm{Fe}_{3} \mathrm{O}_{4}$.

Figura 4- Imagem do aparato experimental empregado na síntese das $\mathrm{NPs}_{-} \mathrm{Fe}_{3} \mathrm{O}_{4}$.

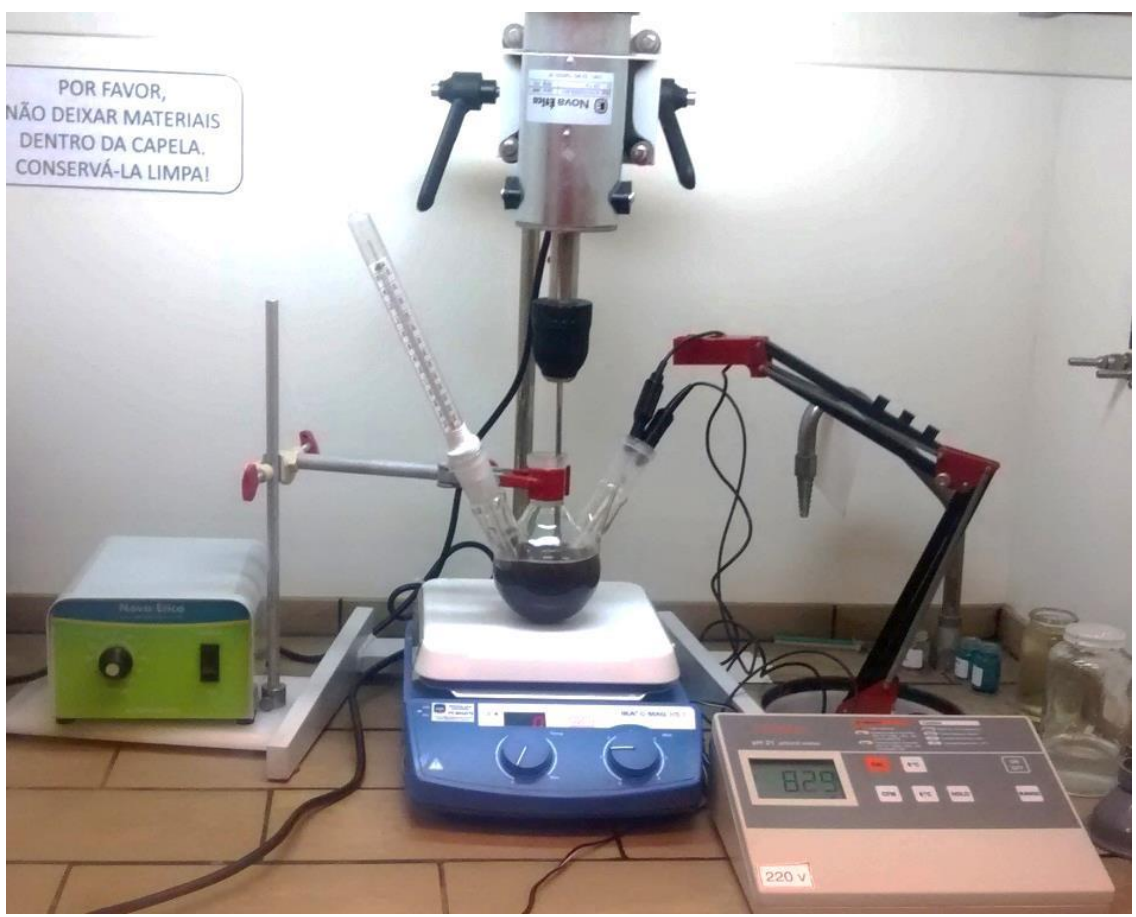

Fonte: Autoria própria. 


\subsection{Síntese das NPs-Au}

NPs-Au foram sintetizadas empregando uma adaptação do método de Brust. ${ }^{90}$ Para isso, prepararam-se duas soluções estoque, sendo a primeira uma solução equimolar de $\mathrm{HCl}$ e $\mathrm{HAuCl}_{4} .3 \mathrm{H}_{2} \mathrm{O} 50 \mathrm{mmol} \mathrm{L}^{-1}$ (solução I), e a segunda, uma solução equimolar de $\mathrm{NaOH}$ e $\mathrm{NaBH}_{4}$ $50 \mathrm{mmol} \mathrm{L}^{-1}$ (solução II). Em seguida, sob agitação, foram adicionados $200 \mu \mathrm{L}$ da solução I a um tubo de ensaio contendo 19,2 mL de água ultrapura. Depois, a esse tubo de ensaio, adicionaram-se $600 \mu \mathrm{L}$ da solução II, sendo observada uma rápida mudança na coloração do meio, evidenciando a formação das NPs-Au em meio aquoso. Durante a adição do agente redutor (Solução II), a coloração do meio mudou imediatamente de amarelo claro para laranja e, em seguida, para vermelho.

\subsection{Obtenção das $\mathrm{NPs}_{3} \mathrm{Fe}_{3} \mathrm{O}_{4}$ decoradas com NPs-Au}

Duas rotas de síntese, modificação in situ e ex situ, foram utilizadas para a obtenção das $\mathrm{NPs}-\mathrm{Fe}_{3} \mathrm{O}_{4}$ decoradas com NPs-Au, como ilustra a Figura 5. Para a modificação in situ, primeiramente, adicionaram-se $400 \mu \mathrm{L}$ da suspensão estoque de $\mathrm{NPs}^{-} \mathrm{Fe}_{3} \mathrm{O}_{4}$ ao um tubo de ensaio contendo 19,2 mL de água ultrapura. Depois, com ajuda de um banho de ultrassom, as $\mathrm{NPs}-\mathrm{Fe}_{3} \mathrm{O}_{4}$ presentes em suspensão foram dispersadas de forma homogênea. Em seguida, essas NPs foram magneticamente separadas do sobrenadante e novamente dispersas em 19,2 mL de água ultrapura. Posteriormente, sob agitação, $200 \mu \mathrm{L}$ da solução I foram adicionados ao tubo de ensaio contendo as $\mathrm{NPs}_{-} \mathrm{Fe}_{3} \mathrm{O}_{4}$. Por fim, adicionaram-se $600 \mu \mathrm{L}$ da solução II ao meio de reação levando à formação e ancoramento das NPs-Au sobre a superfície das $\mathrm{NPs}_{-}-\mathrm{Fe}_{3} \mathrm{O}_{4}$. É importante mencionar que, durante a adição dos $600 \mu \mathrm{L}$ da solução II ao meio de reação, manteve-se o tubo de ensaio em banho de ultrassom por 10 minutos.

Já para modificação ex situ, as NPs-Au foram primeiramente sintetizadas e, em seguida, transferidas a um tubo de ensaio contendo a mesma quantidade de $\mathrm{NPs}_{-}-\mathrm{Fe}_{3} \mathrm{O}_{4}$ empregadas na modificação in situ. Durante a mistura desses dois materiais, o sistema reacional também foi mantido em banho de ultrassom por 10 minutos, levando a obtenção das $\mathrm{NPs}_{-} \mathrm{Fe}_{3} \mathrm{O}_{4}$ decoradas com NPs-Au. 
Figura 5- Ilustração esquemática da obtenção das $\mathrm{NPs}^{-} \mathrm{Fe}_{3} \mathrm{O}_{4}$ decoradas com NPs-Au por meio das modificações in situ (a) e ex situ (b).

a)
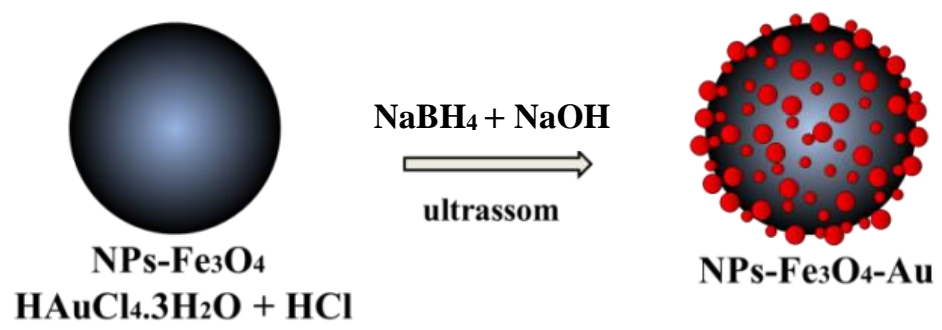

b)
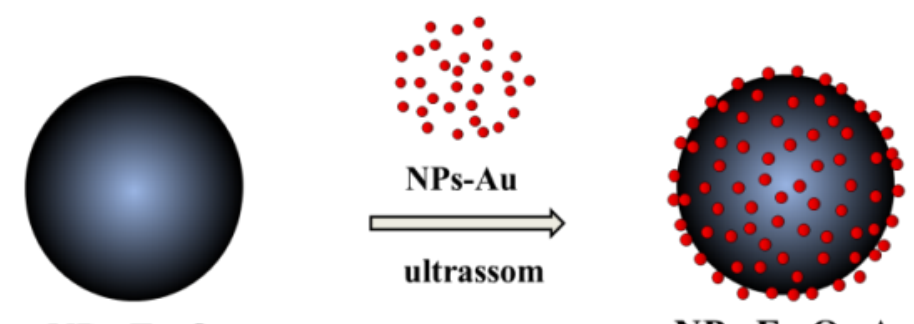

$\mathrm{NPs}_{5}-\mathrm{Fe}_{3} \mathrm{O}_{4}$

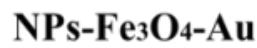

Fonte: Autoria própria.

\subsection{Funcionalização das $\mathrm{NPs}_{-} \mathrm{Fe}_{3} \mathrm{O}_{4}-\mathrm{Au}$ e imobilização do Cyt c}

Como será visto mais adiante no Tópico 4.3, os resultados de MET demonstraram que a modificação ex situ proporcionou um revestimento metálico com maior homogeneidade. Dessa forma, $\mathrm{NPs}-\mathrm{Fe}_{3} \mathrm{O}_{4}$ decoradas com NPs-Au (NPs- $\left.\mathrm{Fe}_{3} \mathrm{O}_{4}-\mathrm{Au}\right)$ via modificação ex situ foram escolhidas para serem utilizadas como plataformas para imobilização do Cyt c. Para isso, realizaram-se os seguintes métodos: primeiramente, $\mathrm{NPs}_{-}-\mathrm{Fe}_{3} \mathrm{O}_{4}-\mathrm{Au}$ foram funcionalizadas com grupos amino e carboxílicos após a modificação de sua superfície utilizando moléculas de cisteína, ${ }^{91}$ enquanto o segundo método permitiu a utilização do GLU como agente de

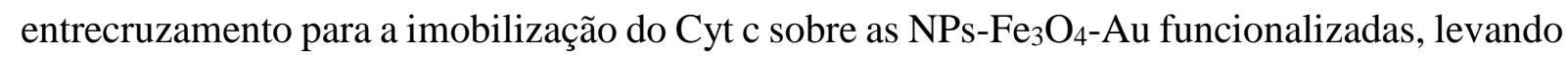
a obtenção do composto NPs-Fe $\mathrm{O}_{4}$-Au-Cyt c. O processo de imobilização do Cyt c ocorreu a partir da reação de reticulação, no qual proporcionou a formação de ligações cruzadas entre os grupos amino (oriundos do Cyt c e das NPs- $\mathrm{Fe}_{3} \mathrm{O}_{4}-\mathrm{Au}$ funcionalizadas) e os grupos aldeídos presentes na estrutura química do GLU. ${ }^{92,93}$

Para a funcionalização das $\mathrm{NPs}-\mathrm{Fe}_{3} \mathrm{O}_{4}-\mathrm{Au}$, empregou-se a seguinte rota: primeiramente, todas as $\mathrm{NPs}-\mathrm{Fe}_{3} \mathrm{O}_{4}-\mathrm{Au}$ presentes em 3 diferentes suspensões (cada suspensão apresentou uma 
concentração comum de aproximadamente $0,19 \mathrm{mg} \mathrm{mL}^{-1}$ ) foram decantadas magneticamente, separadas do sobrenadante e, em seguida, lavadas com água ultrapura (esse processo de lavagem foi realizado por três vezes). Posteriormente, essas NPs foram transferidas para um único recipiente contendo $20 \mathrm{~mL}$ de uma solução de cisteína $60 \mathrm{mmol} \mathrm{L}^{-1}$. Depois, sob uma atmosfera não inerte composta por ar atmosférico, a suspensão resultante foi mantida em agitação mecânica por 24 horas, levando a funcionalização da superfície das $\mathrm{NPs}_{-}-\mathrm{Fe}_{3} \mathrm{O}_{4}-\mathrm{Au}$ com grupos amino e carboxílicos. Em seguida, as $\mathrm{NPs}-\mathrm{Fe}_{3} \mathrm{O}_{4}-\mathrm{Au}$ funcionalizadas foram lavadas inúmeras vezes com água ultrapura a fim de remover o excesso de moléculas fracamente adsorvidas em sua superfície. Por fim, após o processo de lavagem, todas as $\mathrm{NPs}_{-}-\mathrm{Fe}_{3} \mathrm{O}_{4}-\mathrm{Au}$ funcionalizadas foram redispersas em $20 \mathrm{~mL}$ de água, levando a uma suspensão estoque de $1,19 \mathrm{mg} \mathrm{mL}^{-1}$.

Para o segundo método, referente a imobilização do Cyt c, primeiramente, $10 \mathrm{mg}$ de $\mathrm{NPs}-\mathrm{Fe}_{3} \mathrm{O}_{4}$ - $\mathrm{Au}$ funcionalizadas foram transferidas para uma solução contendo $1 \mathrm{~mL}$ de Cyt c 0,25 mg mL $\mathrm{m}^{-1}$ - solução preparada em tampão fosfato de sódio $50 \mathrm{mmol} \mathrm{L}^{-1}, \mathrm{pH} \mathrm{7,0.} \mathrm{Depois,}$ nessa solução, adicionaram-se $20 \mu \mathrm{L}$ de GLU 25\%. Em seguida, manteve-se o meio reacional sob agitação mecânica por 24 horas à temperatura ambiente, levando a imobilização do Cyt c sobre a superfície das $\mathrm{NPs}_{-} \mathrm{Fe}_{3} \mathrm{O}_{4}-\mathrm{Au}$ funcionalizadas ( $\mathrm{NPs}-\mathrm{Fe}_{3} \mathrm{O}_{4}-\mathrm{Au}-\mathrm{Cyt}$ c). Por fim, o composto NPs-Fe ${ }_{3} \mathrm{O}_{4}-\mathrm{Au}-\mathrm{Cyt}$ c presente em suspensão foi decantado magneticamente, separado cuidadosamente do sobrenadante e transferido para um frasco contendo $1,3 \mathrm{~mL}$ de tampão fosfato de sódio $50 \mathrm{mmol} \mathrm{L}^{-1}$.

\subsection{Controle magnético comutável da reação de transferência direta de elétrons do Cyt c}

Para a realização do controle magnético comutável da reação transferência direta de elétrons do Cyt c, primeiramente, $1,3 \mathrm{~mL}$ da suspensão contendo o composto $\mathrm{NPs}-\mathrm{Fe}_{3} \mathrm{O}_{4}-\mathrm{Au}-\mathrm{Cyt}$ c foram adicionados em uma cela eletroquímica (cubeta de polimetilmetacrilato com um volume de $3,5 \mathrm{~mL}$ ) composta por três eletrodos: nesse caso, utilizou-se um eletrodo de trabalho constituído por uma lâmina de ouro $\left(1,24 \mathrm{~cm}^{2}\right)$, prata/cloreto de prata saturado em $\mathrm{KCl}\left(\mathrm{Ag} / \mathrm{AgCl}_{\text {sat }}\right)$ como eletrodo referência e um fio de platina como contra eletrodo. Em seguida, voltamogramas cíclicos foram obtidos após posicionar o imã de neodímio-ferro-boro $(B=0,2 \mathrm{~T})$ atrás do eletrodo trabalho, fazendo com que o composto $\mathrm{NPs}-\mathrm{Fe}_{3} \mathrm{O}_{4}-\mathrm{Au}-\mathrm{Cyt} \mathrm{c}$ presente em suspensão permanecesse depositado sobre a superfície eletródica, modo switch on. Por outro lado, quando nenhum campo magnético foi aplicado (modo switch off), o composto $\mathrm{NPs}_{-}-\mathrm{Fe}_{3} \mathrm{O}_{4}-\mathrm{Au}-\mathrm{Cyt} \mathrm{c}$ decantou para o fundo da cela 
eletroquímica por meio da ação da gravidade, sendo observada somente a resposta eletroquímica do eletrodo de trabalho.

Contudo, vale ressaltar que, antes da realização desse experimento, determinou-se o valor de campo magnético ao ser utilizado o modo switch on. Para isso, posicionou-se um imã de neodímio-ferro-boro atrás do eletrodo de ouro. Movendo o imã ao longo do plano do eletrodo, foi possível variar o valor de campo magnético na superfície eletródica. Nesse caso, para a menor distância entre o imã e o eletrodo de ouro, o valor máximo de campo magnético observado foi de 0,2 T (valor determinado por meio de um guassímetro MagMeter MGM-20). A Figura 6 ilustra o controle magnético comutável da reação transferência eletrônica direta do Cyt c empregando os modos switch on e switch off.

Figura 6- (a) Representação esquemática do controle magnético comutável da reação de transferência direta de elétrons do Cyt c empregando os modos switch on (lado esquerdo) e switch off (lado direito).
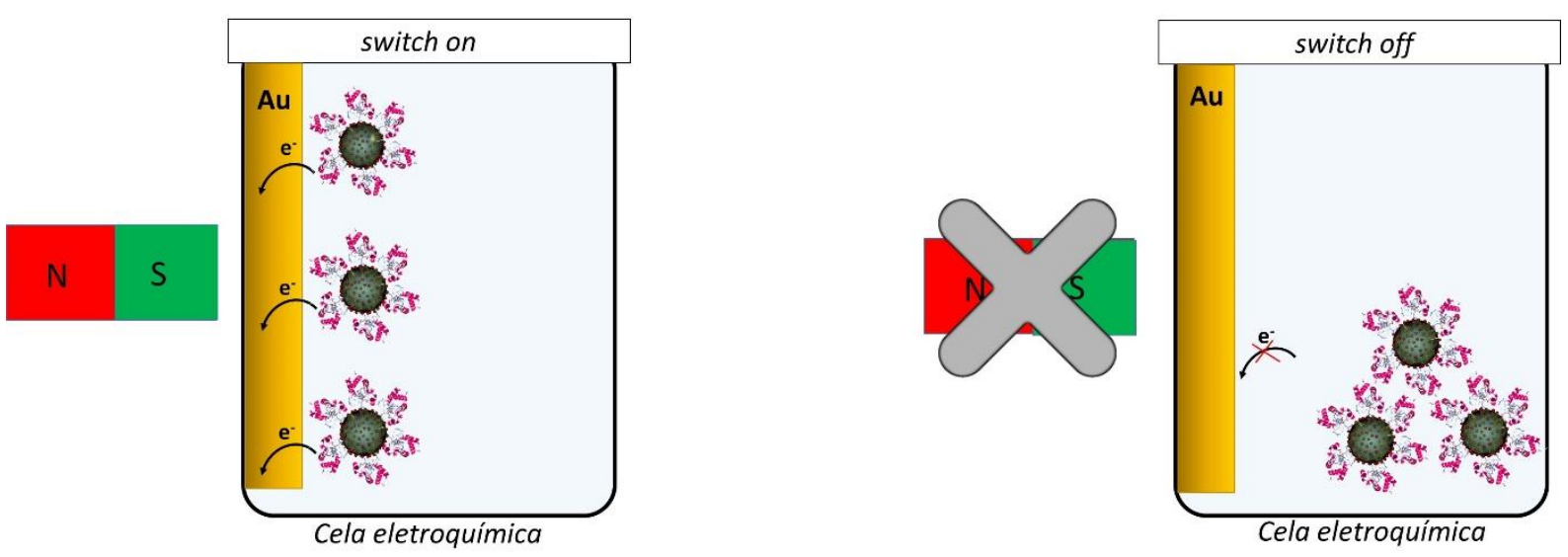

Fonte: Autoria própria. 


\section{Resultados e discussão}

\subsection{Síntese e caracterização das $\mathrm{NPs}_{3}-\mathrm{Fe}_{3} \mathrm{O}_{4}$}

$\mathrm{NPs}-\mathrm{Fe}_{3} \mathrm{O}_{4}$ foram sintetizadas pelo método de coprecipitação. ${ }^{89}$ Esse método consiste em uma reação de alcalinização controlada na presença de uma atmosfera inerte (equação 1). Para isso, adicionou-se lentamente uma base forte $\left(250 \mathrm{~mL}\right.$ de $\left.\mathrm{NaOH} 1,5 \mathrm{~mol} \mathrm{~L}^{-1}\right)$ a uma solução contendo sais de ferro (II) e (III) até que o meio apresentasse um pH entre 9,0 e 10,0. A fim de favorecer a formação das $\mathrm{NPs}-\mathrm{Fe}_{3} \mathrm{O}_{4}$ e evitar a presença de outras fases de óxido de ferro, todo o sistema foi mantido sob atmosfera de nitrogênio. Ademais, fez-se necessária uma vigorosa agitação $(20 \mathrm{rpm})$ no intuito de minimizar gradientes de temperatura e de concentração de reagentes.

$$
\mathrm{Fe}^{2+}{ }_{(\mathrm{aq})}+2 \mathrm{Fe}^{3+}{ }_{(\mathrm{aq})}+8 \mathrm{OH}_{(\mathrm{aq})}^{-} \rightarrow \mathrm{Fe}_{3} \mathrm{O}_{4}(\mathrm{~s})+4 \mathrm{H}_{2} \mathrm{O}(\mathrm{l})
$$

Eq. 1

Dentre as várias metodologias utilizadas na obtenção das $\mathrm{NPs}_{-}-\mathrm{Fe}_{3} \mathrm{O}_{4},{ }^{94,95}$ o método de coprecipitação é o mais simples e permite a obtenção de NPs em meio aquoso empregando uma rota de síntese livre de solvente orgânico e sem a presença de polieletrólitos ou moléculas de surfactantes. No entanto, por causa da baixa temperatura empregada durante a síntese, cerca de $80^{\circ} \mathrm{C}$, as $\mathrm{NPs}-\mathrm{Fe}_{3} \mathrm{O}_{4}$ foram obtidas com um alto grau de polidispersividade e sem um controle morfológico. ${ }^{96}$

Imagens de MET foram obtidas a fim de avaliar a morfologia e o tamanho médio das $\mathrm{NPs}-\mathrm{Fe}_{3} \mathrm{O}_{4}$, como apresenta a Figura 7a. Analisando essa imagem, observam-se NPs- $\mathrm{Fe}_{3} \mathrm{O}_{4}$ com morfologia cúbica e esférica, apresentando um tamanho médio em torno de 11,9 nm. Além

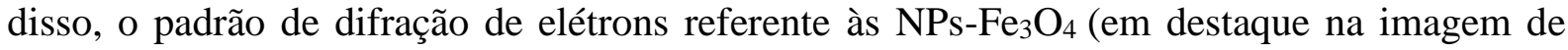
MET) apresenta anéis de difração bem definidos, comprovando a obtenção de $\mathrm{NPs}^{-\mathrm{Fe}_{3} \mathrm{O}_{4}}$ policristalinas. 


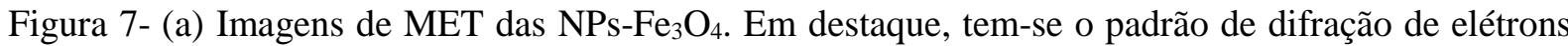
referente às $\mathrm{NPs}_{-}-\mathrm{Fe}_{3} \mathrm{O}_{4}$. (b) Histograma e ajuste log-normal da distribuição de tamanho para as $\mathrm{NPs}-\mathrm{Fe}_{3} \mathrm{O}_{4}$.
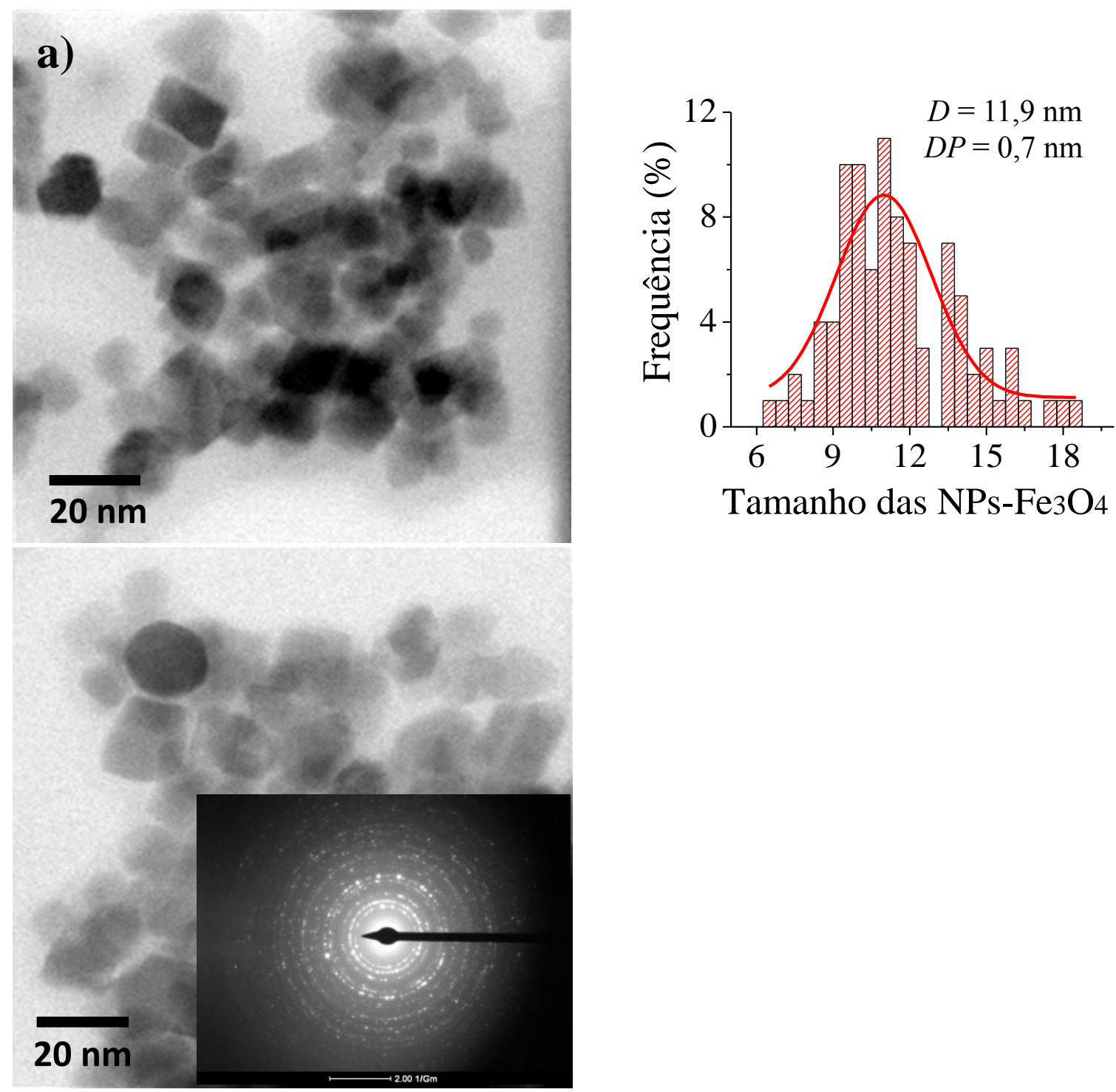


\subsection{Síntese e caracterização das NPs-Au}

As NPs-Au foram sintetizadas empregando uma adaptação do método de Brust, ${ }^{90}$ conhecido como o método de redução química. Uma das principais características dessa metodologia é a obtenção de NPs metálicas monodispersas sem a presença de moléculas de surfactantes ou polieletrólitos. Por UV-Vis, foi possível comprovar a formação das NPs-Au em suspensão aquosa e avaliar o acompanhamento temporal referente ao crescimento dessas NPs metálicas. A Figura 8 apresenta os espectros de UV-Vis da solução de $\mathrm{HAuCl}_{4} \cdot 3 \mathrm{H}_{2} \mathrm{O}$ 0,50 $\mathrm{mmol} \mathrm{L}^{-1}$ (linha preta) e das NPs-Au (linha vermelha) obtidas após a etapa de envelhecimento (crescimento lento).

Antes da formação das NPs-Au (linha preta), observa-se apenas uma única banda de absorção em $300 \mathrm{~nm}$ referente à troca de carga metal-ligante do complexo $\mathrm{AuCl}_{4}{ }^{-} \cdot{ }^{97,98} \mathrm{Com}$ adição de $300 \mu \mathrm{L}$ da Solução II ao tubo de ensaio contendo $0,50 \mathrm{mmol} \mathrm{L}{ }^{-1}$ de $\mathrm{HAuCl}_{4} \cdot 3 \mathrm{H}_{2} \mathrm{O}$, obteve-se a redução dos íons de ouro, o que levou ao aparecimento de uma banda plasmon bem definida e com absorção máxima em 516 nm (linha vermelha). Nesse caso, à adição do agente redutor proporcionou a mudança imediata da coloração do meio de amarelo claro para laranja, indicando que todos os íons de ouro foram reduzidos a ouro metálico de forma simultânea, nucleação rápida. Em seguida, após sua formação, as NPs-Au presentes em suspensão tenderam ao crescimento devido à etapa de envelhecimento, levando a mudança da coloração da suspensão de laranja para vermelho - veja a imagem em destaque na Figura 8. 
Figura 8- Espectros de UV-Vis da solução de $\mathrm{HAuCl}_{4} \cdot 3 \mathrm{H}_{2} \mathrm{O} 0,50 \mathrm{mmol} \mathrm{L}^{-1}$ (linha preta) e da suspensão de NPs-Au (linha vermelha). Em destaque, tem-se a imagem da solução $\mathrm{HAuCl}_{4} .3 \mathrm{H}_{2} \mathrm{O}$ (lado esquerdo), e das suspensões de NPs-Au antes (meio) e após a etapa de envelhecimento (lado direito).

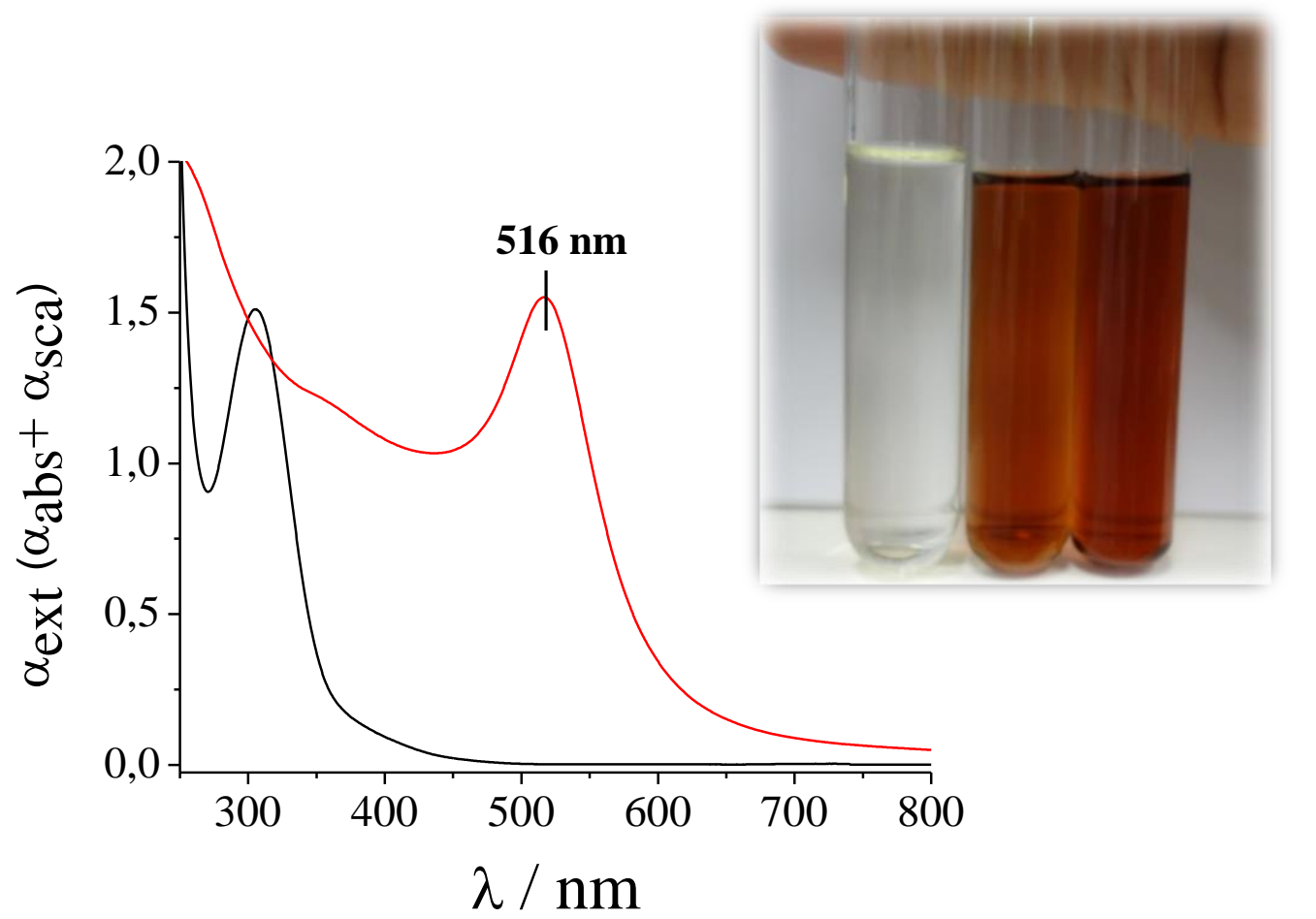

Na Figura 8, o espectro de UV-Vis das NPs-Au, representado pela linha vermelha, apresenta uma banda plasmon com um perfil estreito, indicando que após à etapa de envelhecimento foram obtidas NPs metálicas com baixa polidispersividade. Esse fato corrobora com os resultados obtidos após a análise da imagem de MET (Figura 9a), na qual apresenta NPs-Au monodispersas com uma morfologia esférica. Dessa forma, após a contagem de 100 partículas, o histograma com ajuste gaussiano para distribuição de tamanho das NPs-Au apresenta um diâmetro médio de aproximadamente 3,8 nm (Figura 9b).

De acordo com Martin e colaboradores,${ }^{90}$ a adaptação do método de Brust permite a obtenção de NPs-Au estáveis em meio aquoso devido à repulsão eletrostática ocasionada pela adsorção física de ânions borohidreto $\left(\mathrm{BH}_{4}^{-}\right)$sobre a sua superfície metálica. Entretanto, fora da sweet zone (faixa de concentração na qual as concentrações dos íons $\mathrm{AuCl}_{4}{ }^{-} / \mathrm{H}^{+}$e $\mathrm{BH}_{4}{ }^{-} / \mathrm{OH}^{-}$ podem ser ajustadas a fim de obter NPs-Au monodispersas) essas NPs metálicas apresentam uma baixa estabilidade coloidal. Para isso, sabe-se que, com a mudança das concentrações dos íons $\mathrm{AuCl}_{4}{ }^{-} / \mathrm{H}^{+}$e $\mathrm{BH}_{4} / \mathrm{OH}^{-}$além da faixa de concentração estimada dentro da sweet zone, tem-se a mudança da força iônica do meio, na qual os ânions $\mathrm{BH}_{4}^{-}$com o seu pequeno raio 
hidrodinâmico não são suficientes para manter a estabilidade coloidal da suspensão de NPs-Au resultante. Outra característica desse método é a obtenção de NPs-Au monodispersas. Para isso, é importante mencionar dois pontos: o primeiro é a dissolução de $\mathrm{NaBH}_{4} \mathrm{em}$ uma solução de $\mathrm{NaOH} 50 \mathrm{mmol} \mathrm{L}^{-1}$ a fim de assegurar a estabilidade química dos ânions $\mathrm{BH}_{4}^{-}$(íons presentes na Solução II) durante várias horas à temperatura ambiente; o segundo é a utilização de um forte redutor, fazendo com que todos os íons de ouro livre em solução $\left(\mathrm{AuCl}_{4}{ }^{-}\right)$sejam reduzidos a ouro metálico em menos de 1 segundo, favorecendo a uma nucleação rápida.

Figura 9- Imagem de MET das NPs-Au (a). Histograma e ajuste gaussiano para distribuição de tamanho das NPs-Au apresentando um diâmetro médio de aproximadamente $3,8 \mathrm{~nm}$ (b).
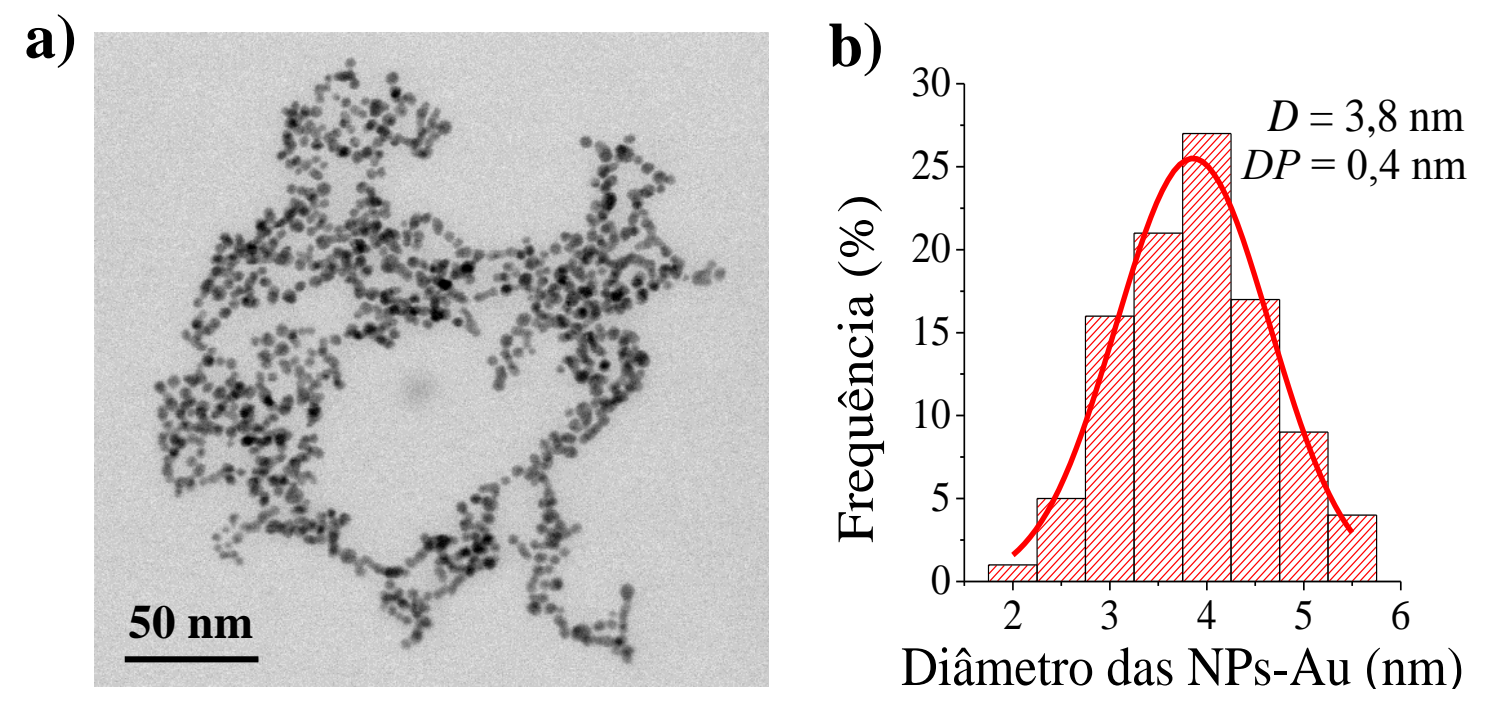

Para avaliar o acompanhamento temporal referente ao crescimento das NPs-Au, obtiveram-se espectros de UV-Vis 1 minuto após a adição de $300 \mu \mathrm{L}$ da solução II (solução equimolar de $\mathrm{NaOH}$ e $\mathrm{BH}_{4} \mathrm{Na} 50 \mathrm{mmol} \mathrm{L}^{-1}$ ) ao tudo de ensaio contendo $0,50 \mathrm{mmol} \mathrm{L}^{-1}$ de $\mathrm{HAuCl}_{4} .3 \mathrm{H}_{2} \mathrm{O}$ (Figura 10a). Para esse último, é importante mencionar que, após a adição do agente redutor ao meio de reação e uma imediata formação das NPs-Au em suspensão aquosa, moléculas de hidrogênio foram liberadas influenciando diretamente no perfil dos espectros de UV-Vis obtidos. Portanto, esse passo garante que todas as moléculas de hidrogênio sejam liberadas primeiramente antes da obtenção dos espectros de UV-Vis, favorecendo uma maior reprodutibilidade na obtenção dos valores de absorção máxima da banda plasmon observados em cada espectro de UV-Vis ilustrados na Figura 10a. 
Figura 10- (a) Espectros de UV-Vis das NPs-Au obtidos 1 min após a adição do agente redutor ao meio de reação. Em destaque, observa-se o aumento dos valores de absorção máxima da banda plasmon e seu deslocamento para menores valores de energia em função do tempo. (b) Acompanhamento temporal referente ao crescimento das NPs-Au, no qual apresenta os valores de absorção máxima da banda plasmon observados nos espectros de UV-Vis na Figura 10a.

a)

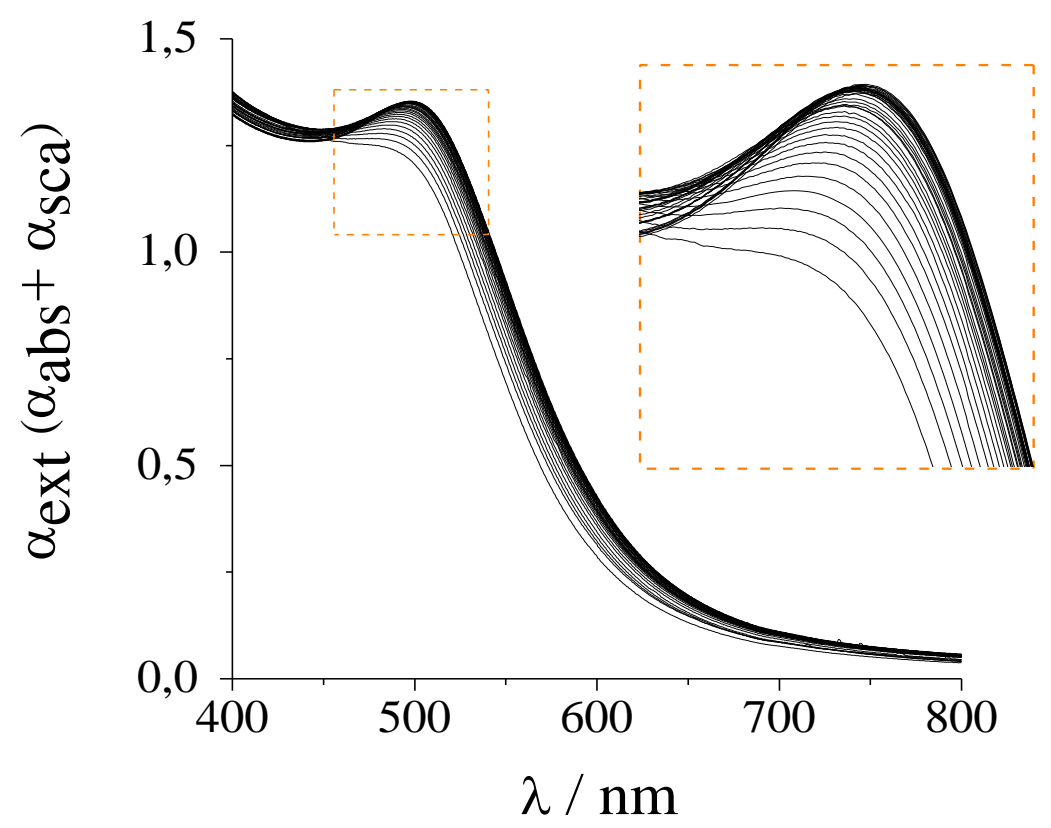

b)

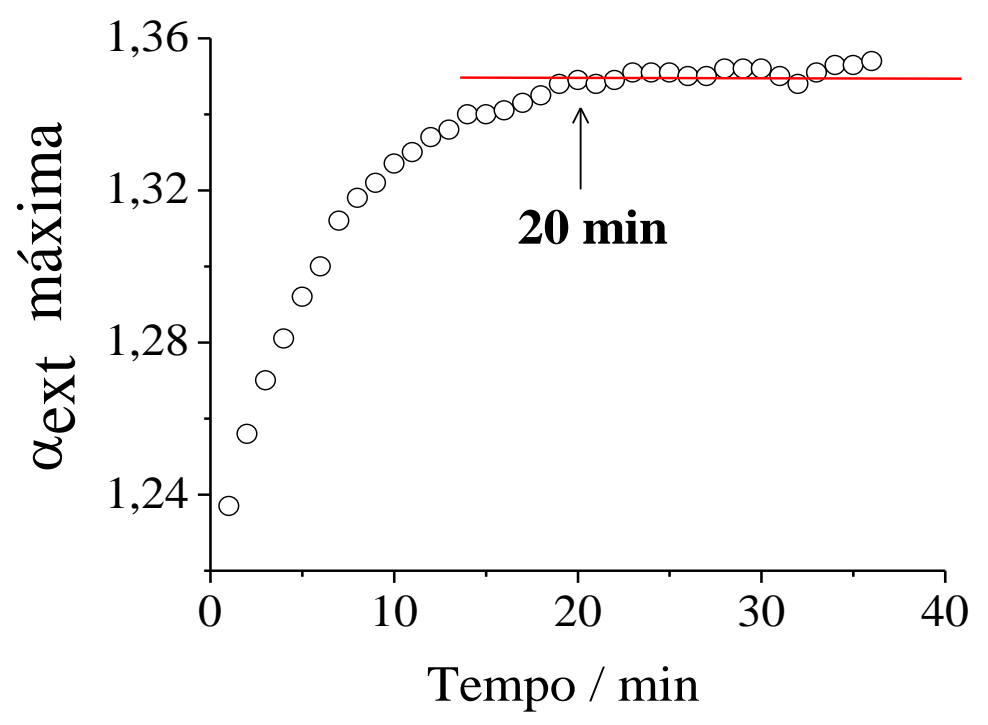


Analisando os espectros de UV-Vis obtidos após a nucleação das NPs-Au (Figura 10a), observa-se um aumento nos valores de absorção máxima da banda plasmon e o seu deslocamento para menores valores de energia em função do tempo. Além disso, como ilustrado na Figura 10b, os valores de absorção máxima da banda plasmon para todos os espectros de UV-Vis atingem um perfil estacionário em torno de 20 minutos; tempo mínimo requerido para que todas as NPs-Au alcancem a etapa de envelhecimento, levando à estabilização de sua energia de superfície. ${ }^{79,99}$

\section{3 $\mathrm{NPs}_{-} \mathrm{Fe}_{3} \mathrm{O}_{4}$ decoradas com NPs-Au: modificação ex situ vs. modificação in situ}

A técnica de DRX foi utilizada a fim de avaliar o perfil cristalográfico das amostras de $\mathrm{NPs}_{-}-\mathrm{Fe}_{3} \mathrm{O}_{4}$ decoradas com NPs-Au por meio das modificações in situ (linha azul) e ex situ (linha vermelha), como mostra a Figura 11. Para os dois difratogramas referentes a essas duas amostras, nenhuma mudança no perfil cristalográfico foi observada. Nesse caso, os picos de difração em $2 \theta$ igual a $35,5^{\circ}$ e $62,8^{\circ}$ se mostram consistentes quando comparados à ficha cristalográfica JCPDS no. 19-629 referente ao padrão de magnetita em estado bulk (linhas verticais pretas). Esses dois picos correspondem, respectivamente, aos planos cristalinos (311) e (440) da estrutura cúbica de espinélio inverso. ${ }^{100}$ Já os picos de difração em $38,2^{\circ}, 44,5^{\circ}$ e 64,6 $6^{\circ}$, correspondentes aos planos cristalinos (111), (200) e (220), respectivamente, foram indexados ao ouro metálico com estrutura cúbica de face centrada. Para esse último, o pico de difração em $38,2^{\circ}$ apresenta uma maior intensidade quando comparada ao pico em $64,6^{\circ}$ - comportamento típico de partículas de ouro em nanoescala. ${ }^{101,102}$ Além disso, outro ponto foi observado: o pico de difração em $38,2^{\circ}$, correspondente ao plano cristalino (111) do ouro, apresenta uma intensidade muito maior do que a do pico em $35,5^{\circ}$ (pico correspondente ao plano cristalino (311) da estrutura cúbica de espinélio inverso). Com isso, presume-se que os revestimentos metálicos obtidos por meio das modificações in situ e ex situ são uniformes e apresentam uma alta concentração de NPs-Au, fazendo com seja dificultada a interação dos feixes de raios $\mathrm{X}$ com a superfície das $\mathrm{NPs}-\mathrm{Fe}_{3} \mathrm{O}_{4}{ }^{103}$ 
Figura 11- Difratogramas referentes às $\mathrm{NPs}_{-} \mathrm{Fe}_{3} \mathrm{O}_{4}$ antes (linha preta) e após as modificações in situ (linha azul) e ex situ (linha vermelha). Fichas cristalográficas JCPDS no. 19-629 e 01-1174 atribuídas aos padrões de magnetita (linhas verticais pretas) e ouro (linhas verticais vermelhas), respectivamente.

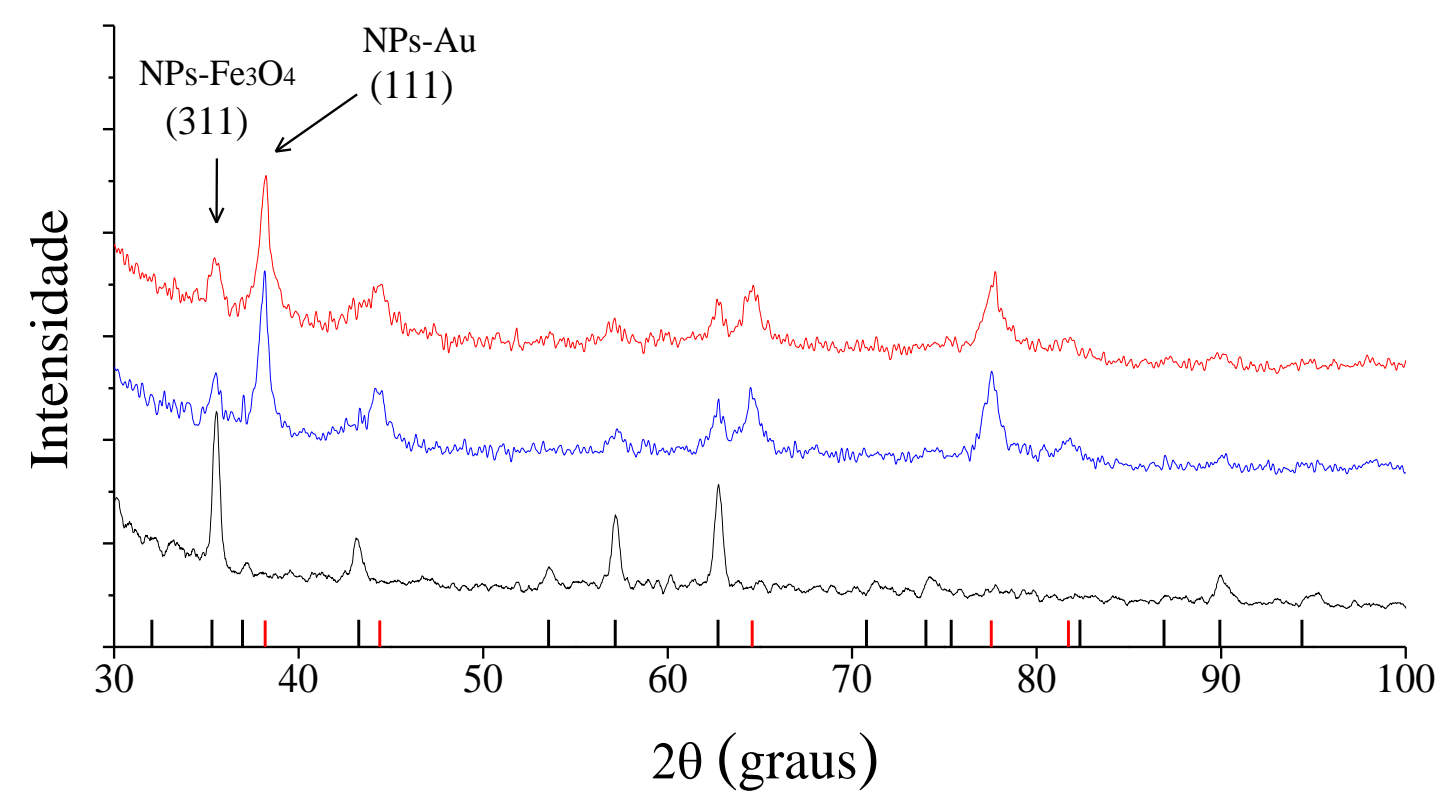

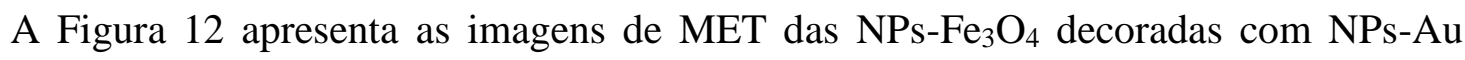
utilizando as modificações in situ e ex situ. Por meio dessas imagens, observam-se que os revestimentos metálicos presentes sobre as $\mathrm{NPs}_{-} \mathrm{Fe}_{3} \mathrm{O}_{4}$ foram obtidos com sucesso, nas quais $\mathrm{NPs}-\mathrm{Au}$, quase monodispersas, apresentaram um diâmetro médio em torno de $3 \mathrm{~nm}$. Além disso, por meio da modificação ex situ, as NPs-Au foram depositadas de forma mais homogênea sobre a superfície das $\mathrm{NPs}-\mathrm{Fe}_{3} \mathrm{O}_{4}$ do que quando utilizada a modificação in situ.

Para a modificação ex situ, é provável que as $\mathrm{NPs}^{-} \mathrm{Fe}_{3} \mathrm{O}_{4}$ não participem quimicamente durante a nucleação das NPs-Au, ou seja, não atuem como um template de nucleação e crescimento, diferentemente do que ocorre na modificação in situ. Além disso, tendo em vista o acompanhamento temporal referente ao crescimento das NPs-Au (Figura 10b), torna-se necessário que essas NPs metálicas sejam misturadas às $\mathrm{NPs}_{-} \mathrm{Fe}_{3} \mathrm{O}_{4}$ em até 20 minutos após a sua nucleação. Caso contrário, as NPs-Au tendem a crescer e estabilizar a sua energia de

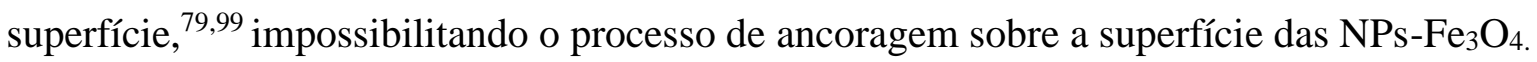


Figura 12- Imagens de MET ( $i$ e ii) e histogramas com ajuste log-normal (iii) para distribuição de tamanho referente às NPs-Au depositadas sobre as $\mathrm{NPs}_{-} \mathrm{Fe}_{3} \mathrm{O}_{4}$ por meio das modificações in situ (a) e ex situ (b).

a)

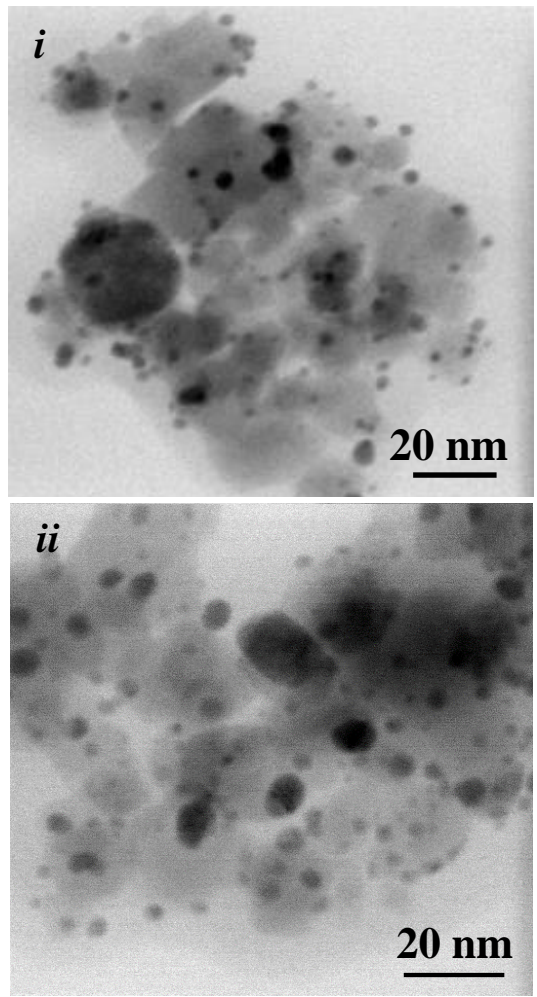

b)

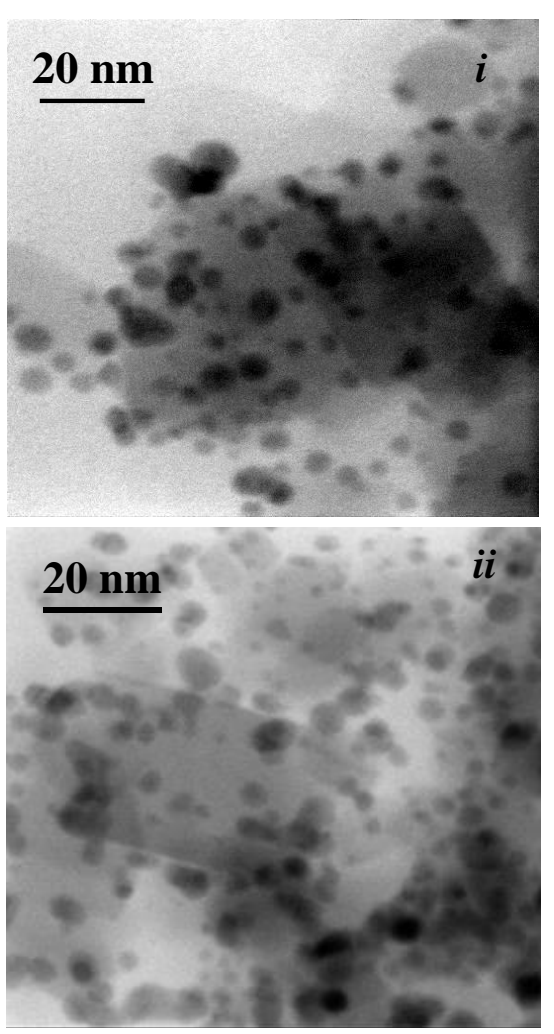

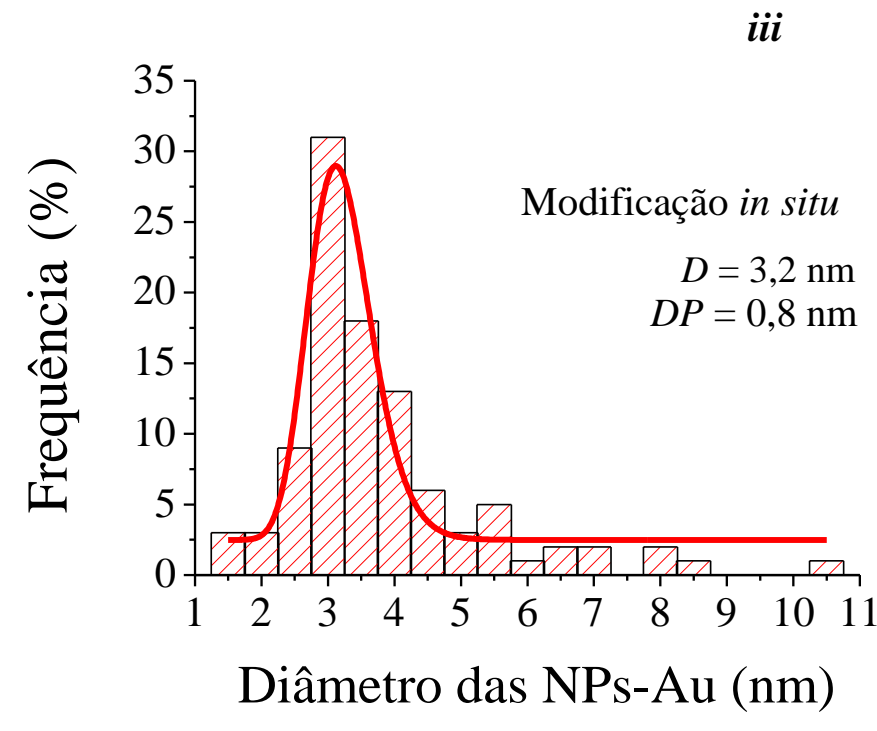

iii

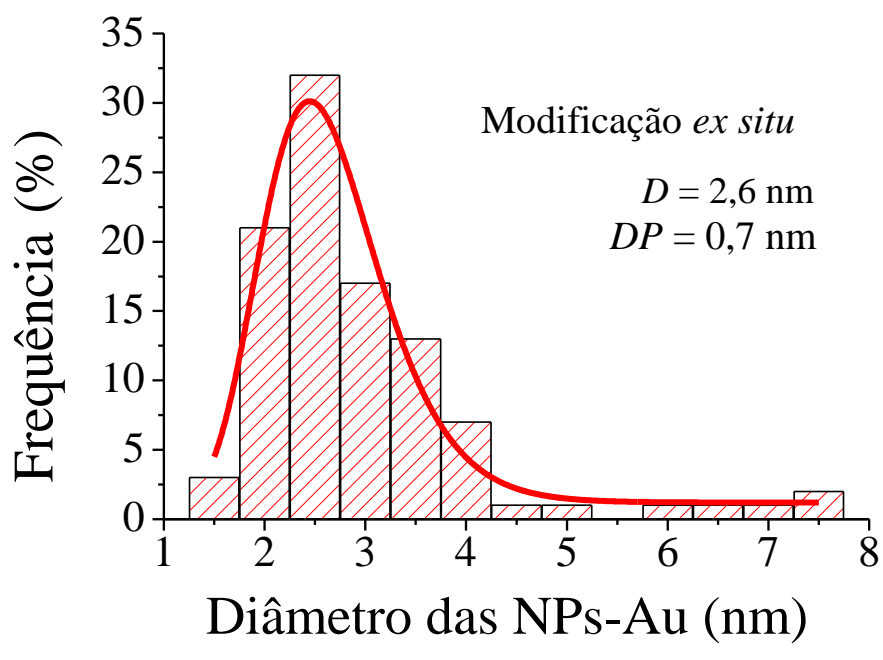


Como observado anteriormente, em destaque na Figura 7a, o padrão de difração de elétrons referente às $\mathrm{NPs}_{-}-\mathrm{Fe}_{3} \mathrm{O}_{4}$ apresenta anéis de difração bem definidos, confirmando a obtenção de partículas nanocristalinas. Entretanto, $\mathrm{NPs}_{-} \mathrm{Fe}_{3} \mathrm{O}_{4}$ são da classe dos óxidos de ferro, e geralmente, esse tipo de material apresenta defeitos estruturais em sua superfície. ${ }^{104-106}$ Dessa forma, acredita-se que esses defeitos sejam locais propícios (sítios de ancoragem) para a deposição e estabilização da energia de superfície das NPs-Au após a utilização das modificações in situ e ex situ.

\subsection{Caracterização das $\mathrm{NPs}_{-} \mathrm{Fe}_{3} \mathrm{O}_{4}$ decoradas com $\mathrm{NPs}-\mathrm{Au}$ via modificação ex situ}

No tópico anterior, foi discutido que a modificação ex situ proporcionou um revestimento metálico com maior homogeneidade, portanto, $\mathrm{NPs}-\mathrm{Fe}_{3} \mathrm{O}_{4}$ decoradas com $\mathrm{NPs}-\mathrm{Au}$ (NPs-Fe $\mathrm{O}_{4}-\mathrm{Au}$ ) empregando essa modificação foram escolhidas para serem aplicadas no controle magnético comutável da reação de transferência direta de elétrons do Cyt c. Tendo isso em vista, a discussão apresentada a seguir se refere exclusivamente a caracterização das $\mathrm{NPs}-\mathrm{Fe}_{3} \mathrm{O}_{4}$ decoradas por meio da modificação ex situ.

Por meio da técnica de espectroscopia de energia dispersiva de raios X (EDX) foi possível estimar a concentração de cada elemento químico presentes nas $\mathrm{NPs}_{-}-\mathrm{Fe}_{3} \mathrm{O}_{4}-\mathrm{Au}$. $\mathrm{Na}$ Figura 13b, analisando o espectro de EDX, observam-se as bandas referentes ao ouro e ao

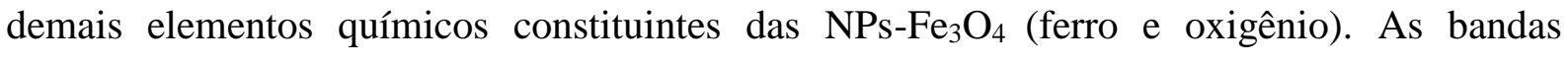
indicando a presença de cobre, no intervalo de 0 e $10 \mathrm{keV}$, são provenientes do material que constitui o porta amostra, enquanto a banda de silício, em torno de $2 \mathrm{keV}$, é decorrente do ataque de $\mathrm{NaOH}$ ao vidro de borosolicato utilizado no preparo das $\mathrm{NPs}-\mathrm{Fe}_{3} \mathrm{O}_{4}-\mathrm{Au}$. Além disso, para esse espectro de EDX, entre 5 e $10 \mathrm{keV}$, a linha de decaimento $\mathrm{K}$ do silício tem um valor de energia semelhante ao da linha de decaimento $\mathrm{M}$ do ouro. Dessa forma, retirando a contribuição do silício e renormalizando a composição da nanoestrutura avaliada, obteve-se a composição apresentada na Tabela 1. Para esse último, os valores ilustrados na coluna da direita indicam os percentuais em massa dos elementos químicos ferro e ouro. 
Figura 13- Imagens MET das NPs- $\mathrm{Fe}_{3} \mathrm{O}_{4}$-Au obtidas durante a análise de EDX (a). Espectro de EDX para a amostra de $\mathrm{NPs}_{-} \mathrm{Fe}_{3} \mathrm{O}_{4}-\mathrm{Au}(\mathrm{b})$.
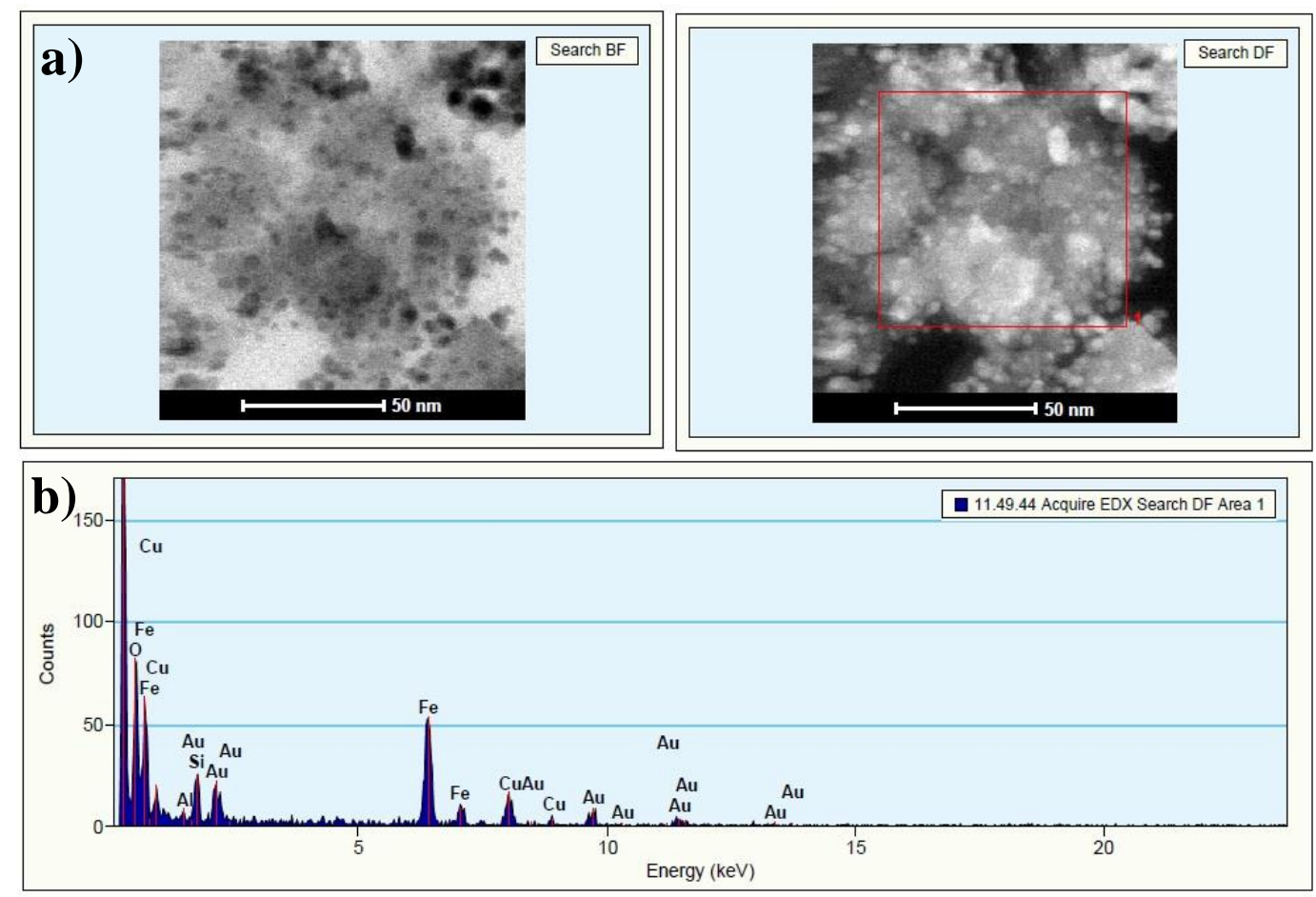

Na Tabela 1, ao ser comparando os valores em massa de todos os elementos químicos que constituem as $\mathrm{NPs}-\mathrm{Fe}_{3} \mathrm{O}_{4}-\mathrm{Au}$, observa-se um revestimento metálico com 35,8\% em massa de ouro. Esse valor corrobora com os resultados de DRX e MET, nos quais comprovam uma alta concentração de NPs-Au.

Tabela 1 - Análise elementar das NPs- $\mathrm{Fe}_{3} \mathrm{O}_{4}$-Au empregando EDX.

\begin{tabular}{c|c}
\hline Elemento & Porcentangem em masssa (\%) \\
\hline $\mathrm{Fe}$ & $64,2 \%$ \\
\hline $\mathrm{Au}$ & $35,8 \%$ \\
\hline
\end{tabular}

A Figura 14 apresenta os espectros de UV-Vis das suspensões de $\mathrm{NPs}^{-\mathrm{Fe}_{3} \mathrm{O}_{4}}$ (linha preta) e das $\mathrm{NPs}_{3}-\mathrm{Fe}_{3} \mathrm{O}_{4}-\mathrm{Au}$ (linha roxa). Para o espectro das $\mathrm{NPs}^{-} \mathrm{Fe}_{3} \mathrm{O}_{4}$, nenhuma banda foi observada na região do UV-Vis, apenas um ombro de baixa intensidade em torno de $350 \mathrm{~nm}$. Esse perfil corresponde ao band-gap indireto de materiais nanopartículados de óxido de ferro com fase cristalina de espinélio inverso (para as $\mathrm{NPs}_{-}-\mathrm{Fe}_{3} \mathrm{O}_{4}$, o valor característico de 


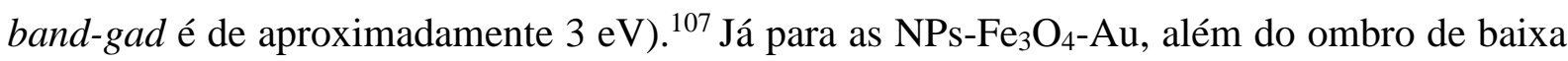
intensidade em torno de $350 \mathrm{~nm}$, observa-se também a presença de uma banda plasmon em $530 \mathrm{~nm}$ oriunda da interação da radiação eletromagnética com superfície das NPs-Au. ${ }^{108} \mathrm{Além}$ disso, nesse mesmo espectro, nota-se um aumento da sua linha de base devido ao espalhamento de luz gerado pelos agregados de NPs-Au sobre as $\mathrm{NPs}-\mathrm{Fe}_{3} \mathrm{O}_{4}$.

Figura 14- (a) Espectros de UV-Vis das suspensões de NPs-Fe ${ }_{3} \mathrm{O}_{4}$ (linha preta) e das $\mathrm{NPs}^{-} \mathrm{Fe}_{3} \mathrm{O}_{4}-\mathrm{Au}$ (linha roxa). (b) Imagens da suspensão de $\mathrm{NPs}_{-}-\mathrm{Fe}_{3} \mathrm{O}_{4}-\mathrm{Au}$ antes (lado esquerdo) e após (lado direito) aplicação de um campo magnético externo.

a)

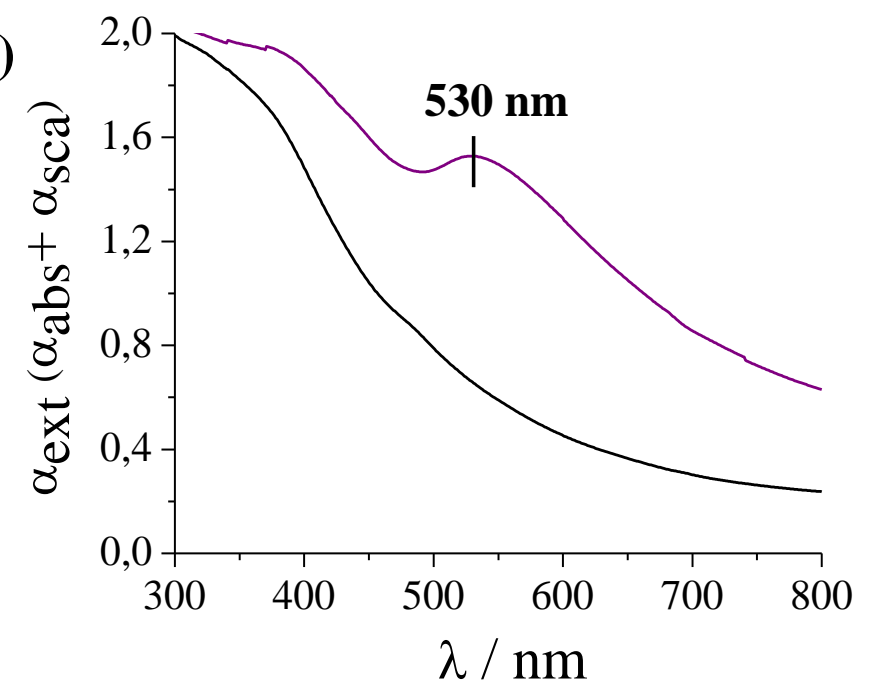

b)

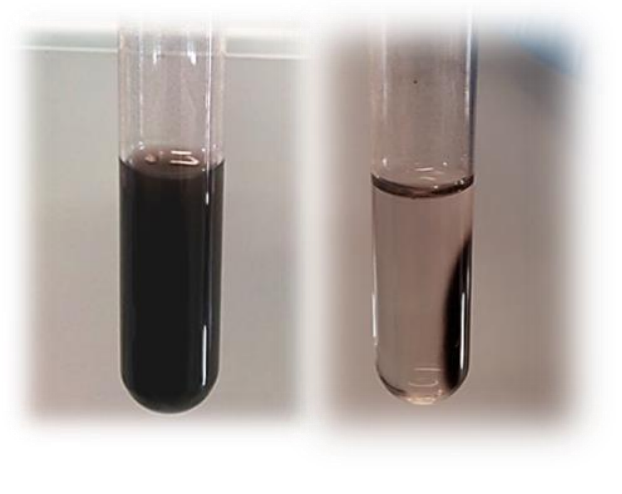

Comparando as bandas plasmon dos espectros de UV-Vis das NPs-Au (Figura 8) e das $\mathrm{NPs}_{-} \mathrm{Fe}_{3} \mathrm{O}_{4}-\mathrm{Au}$ (Figura 14), observa-se o alargamento e o deslocamento dessa banda para menores valores de energias (deslocamento do tipo red-shift de aproximadamente $15 \mathrm{~nm}$ ). Esse deslocamento sugere que as NPs-Au encontram-se aglomeradas após adsorvidas sobre as $\mathrm{NPs}-\mathrm{Fe}_{3} \mathrm{O}_{4}$, permitindo que se acoplem eletronicamente umas com as outras, o que resulta no alargamento da banda plasmon e seu deslocamento para menores valores de energias. ${ }^{109,110}$ Geralmente, em dispersões aquosas de NPs-Au, essa aglomeração provoca a mudança da coloração da suspensão de vermelho para azul. ${ }^{109,110,112}$ Entretanto, para a suspensão de $\mathrm{NPs}_{-}-\mathrm{Fe}_{3} \mathrm{O}_{4}-\mathrm{Au}$, esse fenômeno não foi evidenciado, visto que não foram observadas NPs-Au livres em suspensão após todas as $\mathrm{NPs}-\mathrm{Fe}_{3} \mathrm{O}_{4}$ com superfície modificada terem sido decantadas quando utilizado um campo magnético no valor de 0,2 T. Essa observação é comprovada pelo total desaparecimento da banda plasmon após aplicação do campo magnético, como ilustrado na Figura 15a. Outro ponto importante a ser mencionado é que as $\mathrm{NPs}-\mathrm{Fe}_{3} \mathrm{O}_{4}$-Au se mantêm 
estáveis em suspensão coloidal por várias horas (dado omitido) e, mesmo aglomeradas após aplicação de um campo magnético, podem ser facilmente redispersas em banho de ultrassom, mantendo constantes os valores de absorção da banda plasmon em $530 \mathrm{~nm}$ (Figura 15b). Dessa forma, estudos de UV-Vis sugerem que todas as NPs-Au se encontram fortemente adsorvidas sobre a superfície das $\mathrm{NPs}-\mathrm{Fe}_{3} \mathrm{O}_{4}$.

Figura 15- (a) Espectros de UV-Vis referentes à suspensão de $\mathrm{NPs}_{-} \mathrm{Fe}_{3} \mathrm{O}_{4}-\mathrm{Au}$ antes (i) e após (ii) o processo de decantação magnética $(B=0,2 \mathrm{~T})$. Em (b), tem-se a reprodutibilidade da banda plasmon em

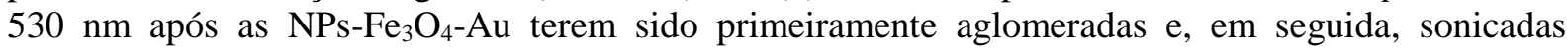
empregando um banho de ultrassom.

a)

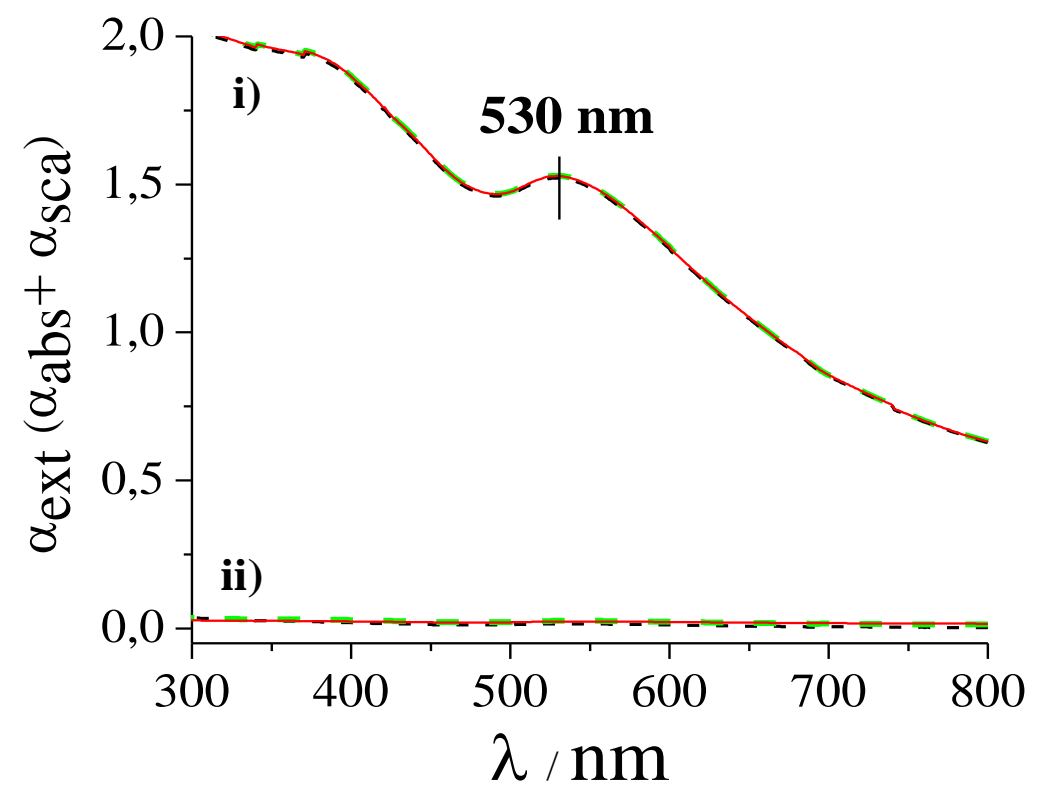

b)

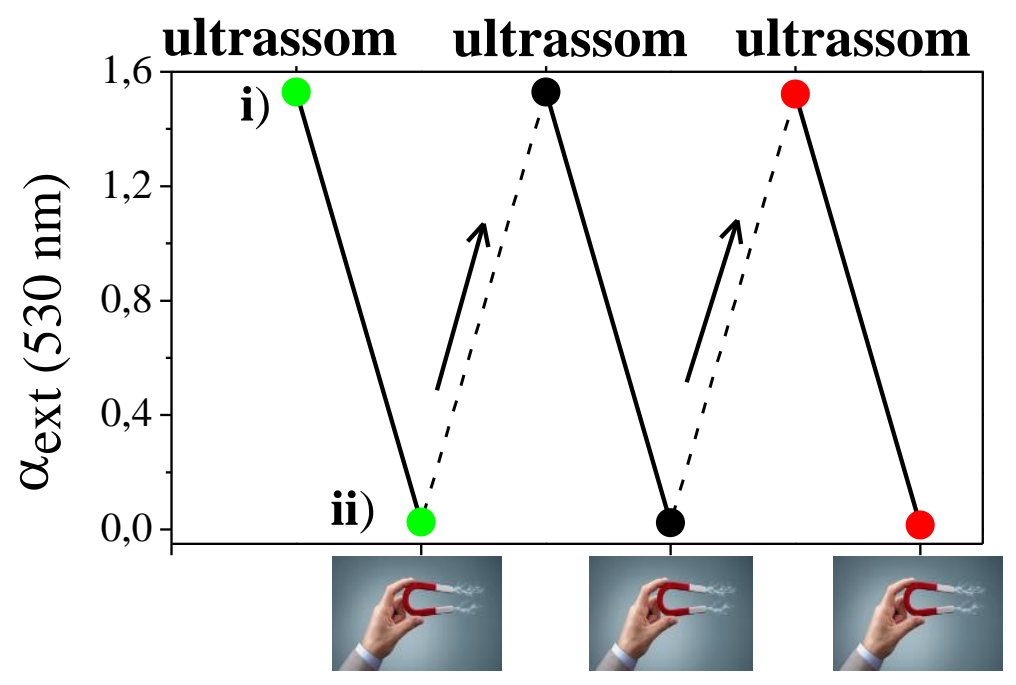




\subsection{Funcionalização das $\mathrm{NPs}-\mathrm{Fe}_{3} \mathrm{O}_{4}-\mathrm{Au}$ utilizando grupos amino e carboxílicos}

As NPs- $\mathrm{Fe}_{3} \mathrm{O}_{4}$-Au foram modificadas com moléculas de cisteína (Cist) a fim de inserir grupos funcionais em sua superfície para a posterior imobilização do Cyt c. Para isso, os prováveis tipos de interação entre a Cist e as $\mathrm{NPs}_{-} \mathrm{Fe}_{3} \mathrm{O}_{4}-\mathrm{Au}$ estão descritos a seguir: (1) os átomos de $\mathrm{S}$ oriundos do grupo tiol (-SH) da cisteína ligam-se aos átomos de ferro e ouro, levando a formação das ligações Fe-S e Au-S, respectivamente; (2) os átomos de Fe interagem com os oxigênios do grupos carboxílicos desprotonados provenientes da cisteína; (3) os átomos de $\mathrm{S}$ ligam-se aos oxigênios presentes nas $\mathrm{NPs}^{-} \mathrm{Fe}_{3} \mathrm{O}_{4}$; (4) adsorção física de moléculas de cistina sobre as $\mathrm{NPs}_{-} \mathrm{Fe}_{3} \mathrm{O}_{4}$-Au após a oxidação da cisteína em contato com a superfície metálica ou de óxido de ferro.

Avaliando os espectros de FTIR da Cist (linha vermelha) e das amostras de $\mathrm{NPs}-\mathrm{Fe}_{3} \mathrm{O}_{4}-\mathrm{Au}$ antes (linha preta) e após (linha azul) a funcionalização com grupos amino e carboxílicos, é possível estabelecer quais das possibilidades descritas acima é a mais provável (Figura 16). Para as $\mathrm{NPs}_{-} \mathrm{Fe}_{3} \mathrm{O}_{4}-\mathrm{Au}$ não funcionalizadas, observam-se as bandas em 592 e $450 \mathrm{~cm}^{-1}$, correspondentes às vibrações das ligações Fe-O. Além disso, existe uma banda de baixa intensidade em torno de $3440 \mathrm{~cm}^{-1}$, atribuída às moléculas de água adsorvidas sobre as $\mathrm{NPs}-\mathrm{Fe}_{3} \mathrm{O}_{4}-\mathrm{Au}$ (esse perfil obtido é idêntico ao encontrado na literatura para $\mathrm{NPs}-\mathrm{Fe}_{3} \mathrm{O}_{4}$ ). ${ }^{113,114}$ Já para a Cist, que se encontra na sua forma zwitteriônica, ${ }^{91,115}$ observa-se uma larga banda entre 2170 e $3350 \mathrm{~cm}^{-1}$, correspondendo majoritariamente aos estiramentos vibracionais referentes aos grupos $-\mathrm{NH}_{3}{ }^{+}$(a banda posicionada em $3180 \mathrm{~cm}^{-1}$ é comumente denominada $v^{\text {as }} \mathrm{NH}_{3}{ }^{+}$, enquanto a banda em $2080 \mathrm{~cm}^{-1}$, corresponde a combinação dos seguintes modos vibracionais: $\delta^{\text {as }} \mathrm{NH}_{3}{ }^{+}$e $\tau^{\mathrm{s}} \mathrm{NH}_{3}{ }^{+}$). Ademais, as bandas posicionadas em 1580 e $1394 \mathrm{~cm}^{-1}$ são referentes às vibrações de estiramento simétrico $\left(v^{\mathrm{s}}\right)$ e assimétrico $\left(v^{\mathrm{as}}\right)$ de COO-, respectivamente. Por outro lado, em 1653, 1610 e $1540 \mathrm{~cm}^{-1}$, observam-se as bandas correspondentes respectivamente aos modos vibracionais $\delta^{\text {as }} \mathrm{NH}_{3}{ }^{+}, \delta^{\text {as' }} \mathrm{NH}_{3}{ }^{+}$e $\delta^{\mathrm{s}} \mathrm{NH}_{3}{ }^{+}$. Por fim, notam-se a presença de outras duas bandas de baixa intensidade, correspondendo ao $v \mathrm{C}-\mathrm{N}$ em $1348 \mathrm{~cm}^{-1} \mathrm{e}$ ao $v \mathrm{~S}-\mathrm{H}$ em $2550 \mathrm{~cm}^{-1} .{ }^{116}$

Comparando a Cist ao espectro de FTIR das $\mathrm{NPs}_{-}-\mathrm{Fe}_{3} \mathrm{O}_{4}-\mathrm{Au}$ funcionalizadas (Figura 16b), observa-se o desaparecimento e deslocamento de várias bandas de absorção. Dentre essas mudanças, destaca-se o desaparecimento do estiramento C-N em $1348 \mathrm{~cm}^{-1} \mathrm{e}$ o deslocamento do $v^{\text {as }}$ de COO- de $1394 \mathrm{~cm}^{-1}$ para $1489 \mathrm{~cm}^{-1}$. Nesse caso, esse deslocamento é proveniente da mudança do momento dipolo da ligação COO- ocasionada pela interação da 
Cist com uma superfície de elevada densidade eletrônica - superfície metal/óxido de ferro. Além disso, é importante mencionar que, o espectro das $\mathrm{NPs}_{-}-\mathrm{Fe}_{3} \mathrm{O}_{4}-\mathrm{Au}$ funcionalizadas apresenta um perfil similar ao da cistina comercial quando essa se encontra na sua forma zwitteriônica (espectro de FTIR ilustrado na Figura 17). ${ }^{117}$ Dessa forma, os dados de FTIR comprovam a existência de cistina adsorvida sobre a superfície das $\mathrm{NPs}-\mathrm{Fe}_{3} \mathrm{O}_{4}-\mathrm{Au}$ após sua modificação empregando moléculas de Cist. ${ }^{91,115}$

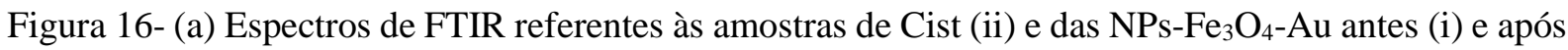
(iii) a etapa de funcionalização. (b) Ampliação da região em destaque na Figura 16a.

a)

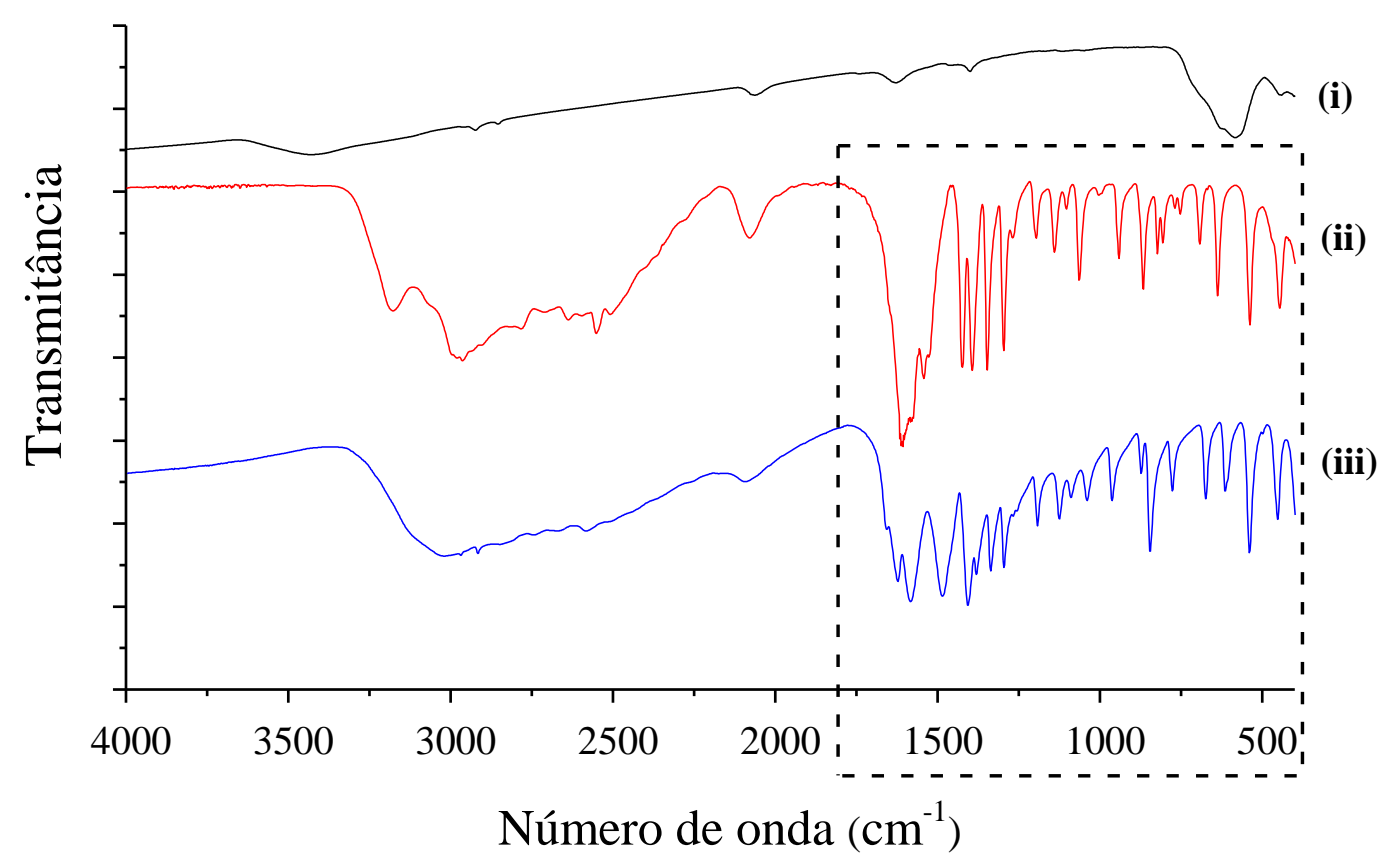

b)

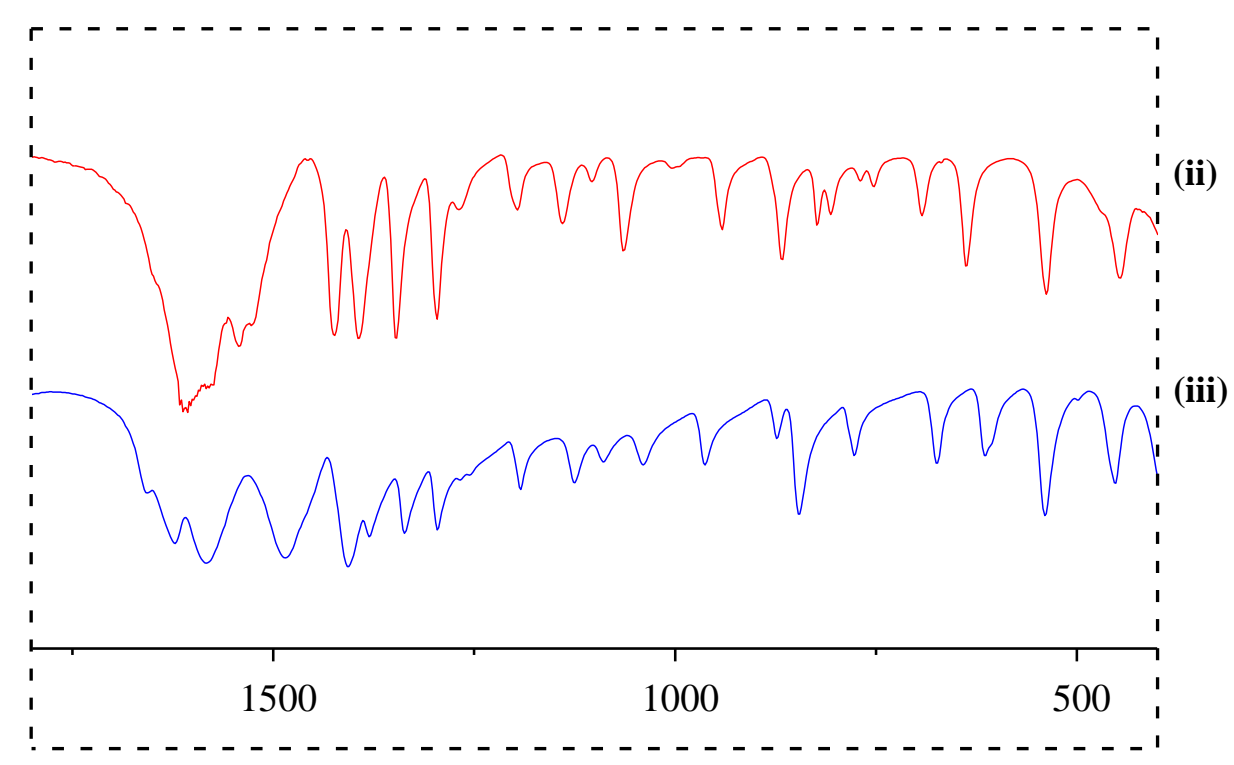


Figura 17- Espectro de FTIR de referência da cistina comercial.

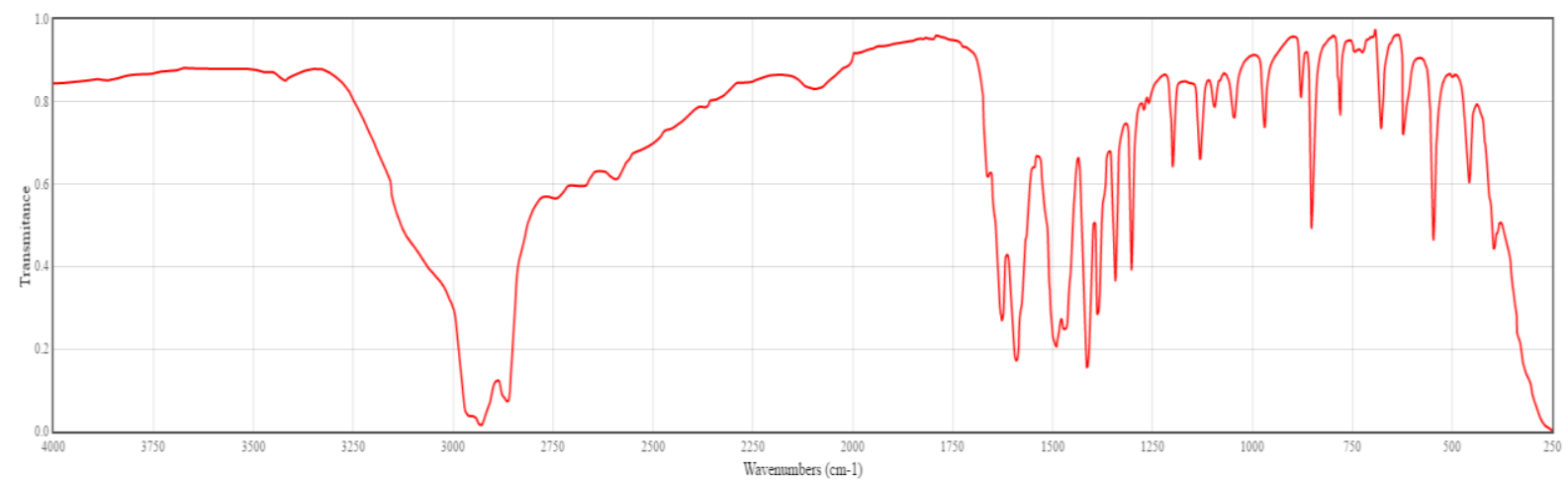

Fonte: NATIONAL INSTITUTE OF STANDARDS AND TECHNOLOGY (NIST). IR spectrum. 2009. Disponível: 〈http://webbook.nist.gov/cgi/cbook.cgi?Name=L-cystine+\&Units=SI\&cIR=on\#IR-Spec〉. Acesso em: 11 de ago. 2016

A Tabela 2 apresenta as atribuições das principais bandas observadas em todos os espectros de FTIR representados na Figura 16.

Tabela 2- Atribuição das bandas nos espectros de FTIR referentes às amostras de Cist (ii) e das $\mathrm{NPs}-\mathrm{Fe}_{3} \mathrm{O}_{4}-\mathrm{Au}$ antes (i) e após (iii) a etapa de funcionalização.

\begin{tabular}{|c|c|c|c|c|c|}
\hline \multicolumn{2}{|c|}{ 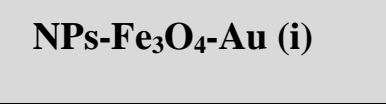 } & \multicolumn{2}{|r|}{ Cist (ii) } & \multicolumn{2}{|c|}{ 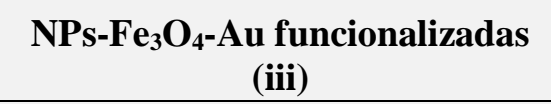 } \\
\hline $\begin{array}{c}\text { Bandas } \\
\left(\mathbf{c m}^{-1}\right)\end{array}$ & Atribuição & $\begin{array}{c}\text { Bandas } \\
\left(\mathbf{c m}^{-1}\right)\end{array}$ & Atribuição & $\begin{array}{c}\text { Bandas } \\
\left(\mathbf{c m}^{-1}\right)\end{array}$ & Atribuição \\
\hline $\begin{array}{l}450 \\
592\end{array}$ & $\begin{array}{l}\mathrm{Fe}-\mathrm{O} \\
\mathrm{Fe}-\mathrm{O}\end{array}$ & $\begin{array}{c}636 \\
804 \\
822 \\
1064 \\
1139 \\
1193 \\
1394 \\
1540 \\
1580 \\
1610 \\
1654 \\
2080 \\
2550 \\
3180\end{array}$ & $\begin{array}{c}\delta \mathrm{COO}^{-} \\
\delta \text { angular } \mathrm{COO}^{-} \\
\delta \text { fora do plano } \mathrm{COO}^{-} \\
v \mathrm{C}-\mathrm{C} / \rho^{\prime} \mathrm{NH}_{3}^{+} \\
\beta, \mathrm{NH}_{3}^{+} \\
\rho^{\prime} \mathrm{NH}_{3}^{+} \\
v^{\text {as }} \mathrm{COO}^{-} \\
\delta^{\mathrm{s}} \mathrm{NH}_{3}^{+} \\
v^{\mathrm{s}} \mathrm{COO}^{-} \\
\delta^{\text {as }} \mathrm{NH}_{3}^{+} \\
\delta^{\text {as }} \mathrm{NH}_{3}^{+} \\
\delta^{\text {as }} \mathrm{NH}_{3}^{+} \tau^{\mathrm{s}} \mathrm{NH}_{3}^{+} \\
v \mathrm{~S}^{+} \mathrm{H}^{+} \\
v^{\text {as }} \mathrm{NH}_{3}{ }^{+}\end{array}$ & $\begin{array}{c}457 \\
457-540 \\
675 \\
1090-1194 \\
1408 \\
1489 \\
1585 \\
1628 \\
1489 \\
1408 \\
2920 \\
3000-3200 \\
3429\end{array}$ & $\begin{array}{c}v \mathrm{~S}-\mathrm{S} \\
\delta \mathrm{C}-\mathrm{C} \\
v \mathrm{C}-\mathrm{S} \\
v \mathrm{C}-\mathrm{C} \\
v^{\text {as }} \mathrm{COO}^{-} / \delta \mathrm{CH}_{2}-\mathrm{CO} \\
\delta^{\text {as }} \mathrm{NH}^{\text {as }} v^{\text {as }} \mathrm{COO}^{-} \\
\delta^{\text {as }} \mathrm{NH}_{3}{ }^{+} \\
\delta^{\text {as }} \mathrm{NH}_{3}{ }^{+} \\
\delta^{\text {as }} \mathrm{NH}^{-} / v^{\text {as }} \mathrm{COO}^{-} \\
v^{\text {as }} \mathrm{COO}^{-} / \delta \mathrm{CH}_{2}-\mathrm{CO} \\
v^{\text {as }} \mathrm{CH}_{2}-\mathrm{S} \\
v \mathrm{C}-\mathrm{H} \\
v^{\text {as }} \mathrm{N}-\mathrm{H}\end{array}$ \\
\hline
\end{tabular}

$(v=$ estiramento, $\delta=$ deformação $)$ 
Na literatura, alguns trabalhos têm reportado a funcionalização de NPs metálicas ${ }^{119}$ e de óxido de ferro ${ }^{91,115}$ utilizando moléculas de cistina após a reação de oxidação de cisteína em contato uma superfície receptora de elétrons. Portanto, baseado nesses estudos prévios, a interação da cistina com a superfície das $\mathrm{NPs}_{-} \mathrm{Fe}_{3} \mathrm{O}_{4}-\mathrm{Au}$ ocorre através dos grupos amino e carboxílicos, e também por meio da sua cadeia alifática. ${ }^{91,115}$ Além disso, outros estudos têm reportado a existência de moléculas de cisteína interagindo com a superfície metálica das NPs-Au após a formação de ligações covalentes do tipo Au-S. ${ }^{118,120}$ Dessa forma, a fim de contornar possíveis ambiguidades, por exemplo, qual tipo de superfície (óxido de ferro, metálica ou ambas) ocorre a interação das moléculas de cistina, realizou-se separadamente a modificação das nanopartículas de magnetita e de ouro utilizando moléculas de cisteína. Como resultado, ao ser comparar o espectro de FTIR das $\mathrm{NPs}_{-}-\mathrm{Fe}_{3} \mathrm{O}_{4}-\mathrm{Au}$ funcionalizadas com essas duas outras amostras, tem-se exatamente o mesmo perfil previamente observado, como ilustrado na Figura 18. Isso comprova a existência moléculas de cistina interagindo com as $\mathrm{NPs}-\mathrm{Fe}_{3} \mathrm{O}_{4},{ }^{91,115}$ bem como na superfície metálica das NPs-Au. ${ }^{119}$

Figura 18- Espectros de FTIR referentes às nanopartículas de magnetita (a) e de ouro (b) modificadas com cisteína; e NPs- $\mathrm{Fe}_{3} \mathrm{O}_{4}$-Au funcionalizadas com grupos amino e carboxílicos (c).

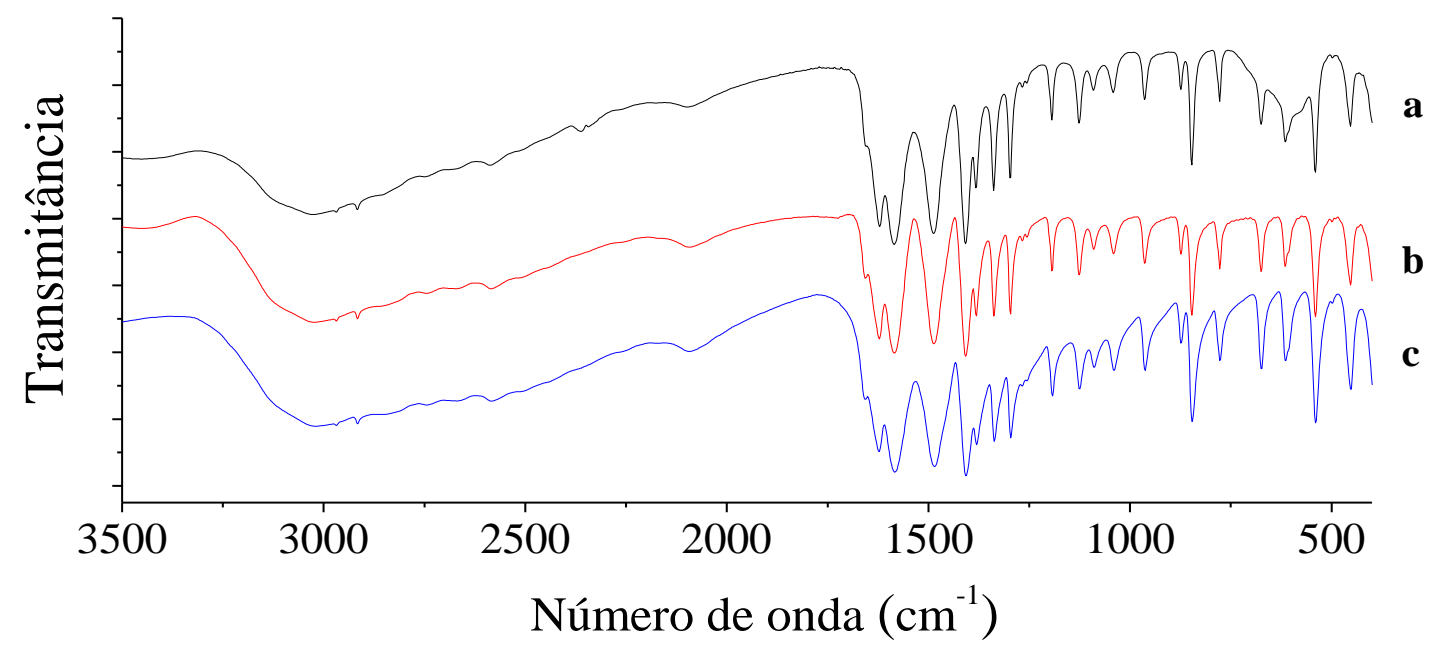

\subsection{Imobilização do Cyt c sobre as $\mathrm{NPs}_{-} \mathrm{Fe}_{3} \mathrm{O}_{4}-\mathrm{Au}$ funcionalizadas}

O agente de entrecruzamento glutaraldeído (GLU) foi utilizado para a imobilização do Cyt c sobre as $\mathrm{NPs}_{-}-\mathrm{Fe}_{3} \mathrm{O}_{4}-\mathrm{Au}$ funcionalizadas, levando a obtenção do composto $\mathrm{NPs}-\mathrm{Fe}_{3} \mathrm{O}_{4}-\mathrm{Au}-\mathrm{Cyt}$ c. Esse processo de imobilização ocorre a partir da reação de reticulação, no qual proporciona a formação de ligações cruzadas entre os grupos amino, oriundos do Cyt c 
e das $\mathrm{NPs}-\mathrm{Fe}_{3} \mathrm{O}_{4}-\mathrm{Au}$ funcionalizadas, e os grupos aldeídos presentes na estrutura química do GLU. ${ }^{92,93}$

Por FTIR, confirmou-se a presença do Cyt c imobilizado sobre as $\mathrm{NPs}_{-}-\mathrm{Fe}_{3} \mathrm{O}_{4}-\mathrm{Au}$ funcionalizadas após a reação de reticulação. A Figura 19 ilustra os espectros de FTIR das amostras de Cyt c (linha laranja) e do composto $\mathrm{NPs}_{-} \mathrm{Fe}_{3} \mathrm{O}_{4}-\mathrm{Au}-\mathrm{Cyt}$ c (linha preta). Para o espectro do Cyt c, observam-se duas bandas em 1656 e $1544 \mathrm{~cm}^{-1}$, correspondentes às vibrações de amida I e II, respectivamente (essas bandas, amida I e II, têm sido amplamente utilizadas para monitorar alterações nas estruturas secundária e terciária de enzimas e proteína redox. ${ }^{121,122}$ ). A banda de amida I é oriunda das vibrações de estiramento $\mathrm{C}=\mathrm{O}$ das ligações peptídicas presentes no backbone da proteína, enquanto à amida II resulta da combinação do estiramento C-N e da deformação N-H presentes nos grupos peptídicos.

De maneira similar ao Cyt c, o espectro de FTIR referente ao composto NPs-Fe ${ }_{3} \mathrm{O}_{4}$-Au-Cyt c (linha preta) também apresenta as bandas de amida I e II. Entretanto, nota-se um deslocamento para menores números de onda. Nesse caso, a banda de amida I deslocou de 1656 para $1647 \mathrm{~cm}^{-1}$, enquanto a amida II deslocou de 1544 para $1539 \mathrm{~cm}^{-1}$. Esse pequeno deslocamento indica que o Cyt c sofreu mudanças conformacionais em sua estrutura terciária após ser imobilizado sobre as $\mathrm{NPs}_{-}-\mathrm{Fe}_{3} \mathrm{O}_{4}-\mathrm{Au}$ funcionalizadas. Para esse último, experimentos mais detalhados precisam ser realizados afim de investigar a disposição do grupo prostético heme na estrutura terciaria do Cyt c após as mudanças conformacionais observadas em decorrência da imobilização dessa proteína redox.

Figura 19- Espectros de FTIR referentes às amostras de Cyt c (linha laranja) e do composto $\mathrm{NPs}-\mathrm{Fe}_{3} \mathrm{O}_{4}$-Au-Cyt c (linha preta).

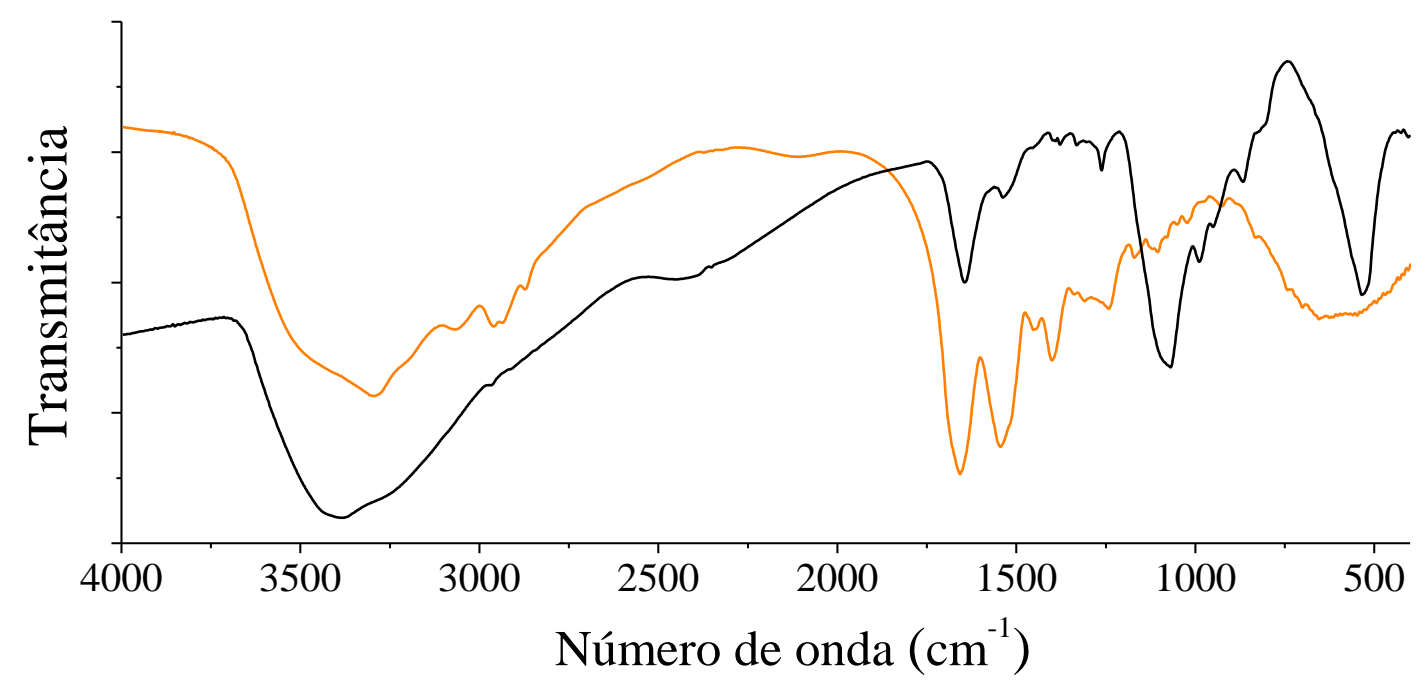


A Tabela 3 apresenta as atribuições das principais bandas observadas nos espectros de FTIR representados na Figura 19.

Tabela 3- Atribuição das bandas nos espectros de FTIR referentes às amostras de Cyt $\mathrm{c}$ e do composto $\mathrm{NPs}-\mathrm{Fe}_{3} \mathrm{O}_{4}$-Au-Cyt c.

\begin{tabular}{ccc}
\hline \multicolumn{2}{c}{ Bandas $\left(\mathbf{c m}^{-1}\right)$} & Atribuição \\
\cline { 1 - 3 } Cyt c & NPs-Fe $_{3} \mathbf{O}_{4}$-Au-Cyt c & \\
\hline 1544 & 1539 & $v$ C-N (amida II) $/ \delta$ angular no plano de N-H \\
1656 & 1647 & $v$ C $=\mathrm{O}$ (amida I) \\
2919 & & $v$ C-H \\
3298 & 3383 & $v$ N-H \\
\hline$(v=$ estiramento, $\delta=$ deformaça $)$ &
\end{tabular}

$(v=$ estiramento, $\delta=$ deformação $)$

Por UV-Vis, determinou-se a quantidade de Cyt c imobilizada em $10 \mathrm{mg}$ de $\mathrm{NPs}_{5}-\mathrm{Fe}_{3} \mathrm{O}_{4}-\mathrm{Au}$ funcionalizadas. Para isso, avaliou-se os espectros de UV-Vis referente à solução de Cyt c antes (linha preta) e após a etapa de imobilização (linha azul), como ilustrado na Figura 20. Para o espectro de UV-Vis do Cyt c, antes da etapa de imobilização, observa-se uma banda Soret (ou banda $\gamma$ ) de forte absorção em $410 \mathrm{~nm}$. Ademais, em torno de $530 \mathrm{~nm}$, nota-se a presença de apenas uma banda de baixa intensidade (banda $\beta$ ), indicando que o mesmo se encontra em seu estado oxidado. ${ }^{123}$ Após as etapas de imobilização do Cyt c, decantação magnética do composto $\mathrm{NPs}-\mathrm{Fe}_{3} \mathrm{O}_{4}$-Au-Cyt c e a sua separação do sobrenadante, o espectro de UV-Vis da solução resultante (linha azul) apresenta uma banda Soret com um máximo de absorbância em $412 \mathrm{~nm}$. Além disso, para esse espectro, a banda Soret apresenta um valor de absorbância 95,8\% menor quando comparada a solução precursora de Cyt c $0,25 \mathrm{mg} \mathrm{mL}^{-1}$.

Por meio da curva de calibração concentração vs. absorbância em 410 nm (curva em destaque na Figura 21 sendo construída a partir de 5 soluções padrão de Cyt c com diferentes concentrações), determinou-se a concentração do Cyt c remanescente no sobrenadante

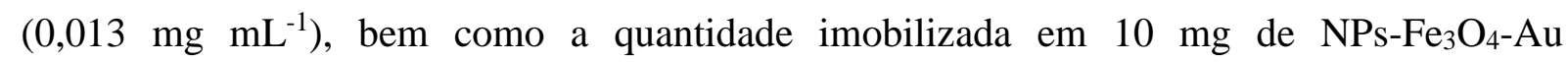
funcionalizadas. Assim, massa de Cyt c imobilizada foi de aproximadamente 0,23 mg. 
Figure 20- Espectros de UV-Vis da solução de Cyt c $0,25 \mathrm{mg} \mathrm{mL}^{-1}$ preparada em tampão fosfato de sódio $50 \mathrm{mmol} \mathrm{L}^{-1}, \mathrm{pH}$ 7,0 (linha preta), do sobrenadante após a imobilização do Cyt c sobre as $\mathrm{NPs}_{-} \mathrm{Fe}_{3} \mathrm{O}_{4}-\mathrm{Au}$ funcionalizadas (linha azul) e da solução de Cyt c $0,25 \mathrm{mg} \mathrm{mL}^{-1}$ deixada sob agitação mecânica após 24 horas (linha amarela) à $22^{\circ} \mathrm{C}$. Em destaque, têm-se as imagens das soluções de Cyt c antes (a) e após (b) a etapa de imobilização utilizando GLU como agente de entrecruzamento.

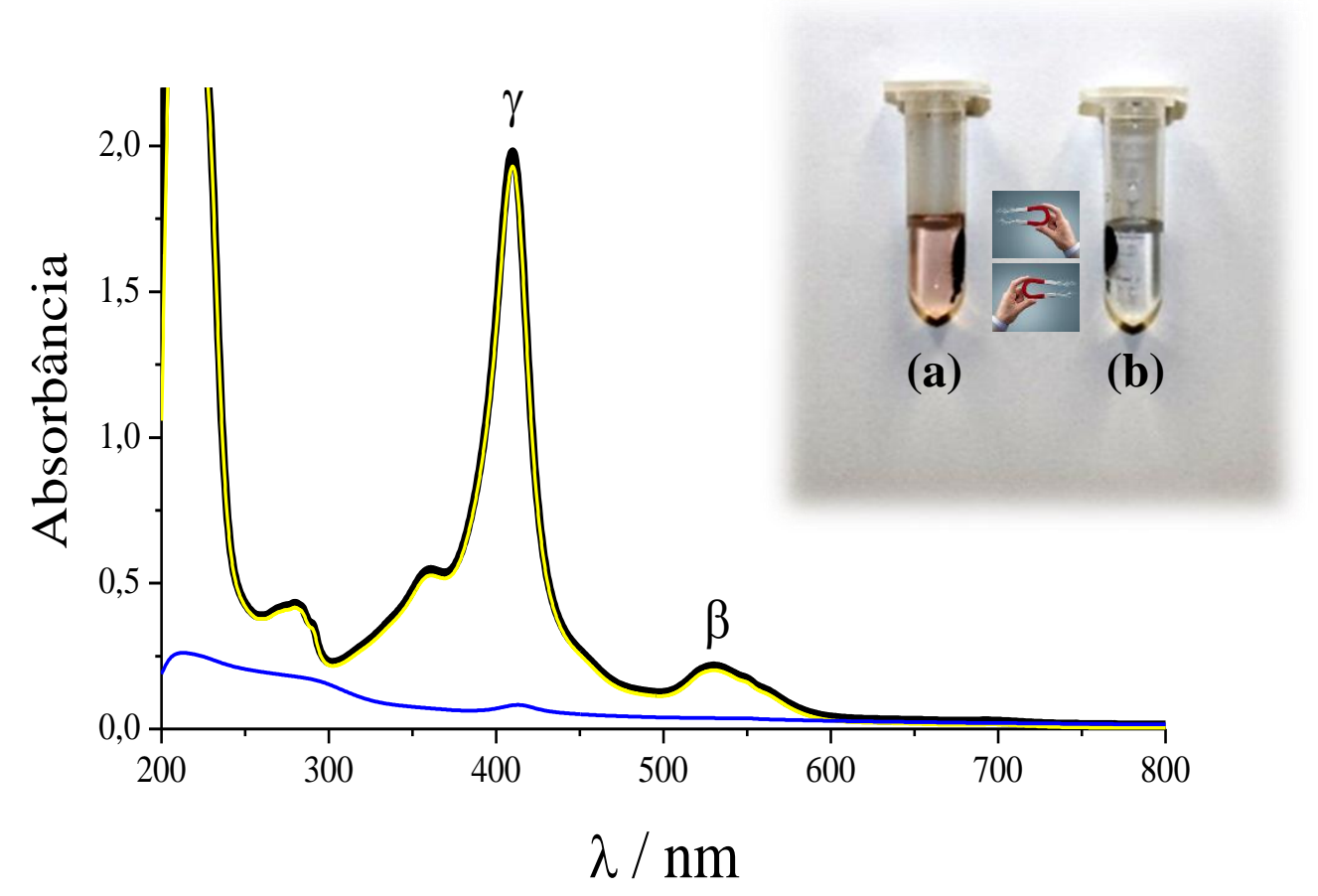

Figura 21- Espectros de UV-Vis obtidos para diferentes soluções padrão de Cyt c preparadas em tampão fosfato de sódio $50 \mathrm{mmol} \mathrm{L}^{-1}, \mathrm{pH} 7,0$. Em destaque, tem-se a curva de calibração obtida em $410 \mathrm{~nm}$ para as soluções de Cyt c com diferentes concentrações $\left(0,0078-0,25 \mathrm{mg} \mathrm{mL}^{-1}\right)$. Temperatura: $22^{\circ} \mathrm{C}$.

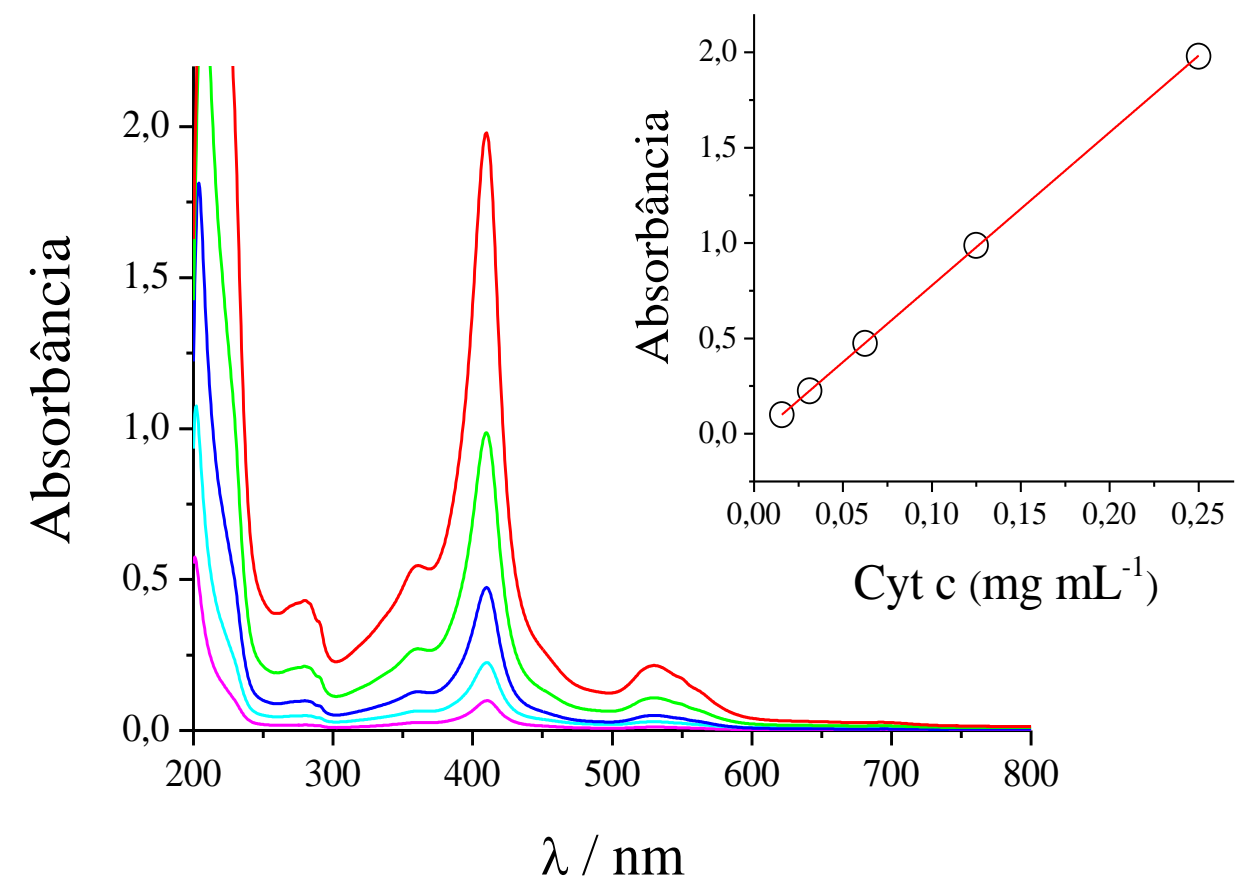


Na literatura, o Cyt c é descrito com uma proteína modelo que apresenta uma excelente caracterização em estado cristalino. Além disso, essa proteína pode ser aplicada em diferentes condições de temperatura e $\mathrm{pH}^{21-23}$ Entretanto, devido a etapa de imobilização do Cyt c, é provável que a sua estrutura secundária seja afetada devido as condições experimentais utilizadas, levando a desnaturação do mesmo. Por UV-Vis, monitoram-se as bandas de absorção (bandas Soret e $\beta$ ) da solução precursora de Cyt c $0,25 \mathrm{mg} \mathrm{mL}^{-1}$ após agitação por 24 horas à temperatura ambiente (linha amarela ilustrada na Figura 20). Como resultado, tem-se um espectro com um perfil similar ao da solução de Cyt c recém preparada, comprovando que apenas a etapa de agitação empregada por 24 horas não ocasiona mudanças conformacionais na estrutura terciaria do Cyt c.

\subsection{Eletroquímica das $\mathrm{NPs}_{-} \mathrm{Fe}_{3} \mathrm{O}_{4}-\mathrm{Au}$ funcionalizadas}

Antes da realização do controle magnético comutável da reação de transferência direta de elétrons do Cyt c, avaliou-se por VC o comportamento eletroquímico do filme magneticamente induzido composto por $\mathrm{NPs}-\mathrm{Fe}_{3} \mathrm{O}_{4}-\mathrm{Au}$ funcionalizadas. Além disso, para um melhor entendimento, avaliaram-se separadamente as interfaces eletródicas constituídas pelos filmes de $\mathrm{NPs}-\mathrm{Fe}_{3} \mathrm{O}_{4}$ e NPs- $\mathrm{Fe}_{3} \mathrm{O}_{4}-\mathrm{Au}$. Para isso, é importante mencionar que, em cada interface elétródica foram realizados 200 ciclos voltamétricos, sendo apresentado na figura a seguir o último voltamograma obtido. Além disso, durante a varredura cíclica da janela de potencial trabalhada (de $-0,25$ a $0,4 \mathrm{~V}$, a $100 \mathrm{mV} \mathrm{s}^{-1}$ ) não foram observadas mudanças significativas no perfil eletroquímico quando comparado o segundo voltamograma ao último obtido. Por fim, a massa utilizada no preparo dos filmes magneticamente induzidos foi de $10 \mathrm{mg}$.

A Figura 22 mostra os voltamogramas cíclicos obtidos para o eletrodo de ouro

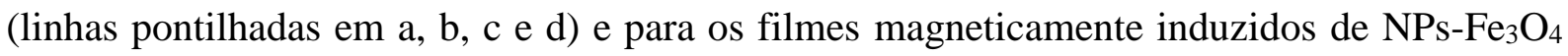
(linhas pretas em a e d), NPs- $\mathrm{Fe}_{3} \mathrm{O}_{4}-\mathrm{Au}$ (linhas vermelhas em b e d) e $\mathrm{NPs}_{-}-\mathrm{Fe}_{3} \mathrm{O}_{4}-\mathrm{Au}$ funcionalizadas (linhas azuis em c e d). Nesse caso, as interfaces eletródicas constituídas pelos filmes de $\mathrm{NPs}-\mathrm{Fe}_{3} \mathrm{O}_{4}$ e $\mathrm{NPs}-\mathrm{Fe}_{3} \mathrm{O}_{4}-\mathrm{Au}$ apresentam um comportamento semelhante ao de um

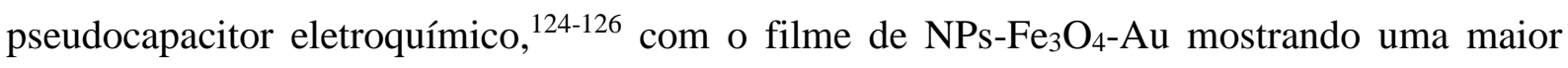
corrente capacitiva quando comparada a filme de $\mathrm{NPs}_{-}-\mathrm{Fe}_{3} \mathrm{O}_{4}$. Além disso, para esses dois materiais, observa-se um processo de oxidação irreversível em potencial negativo próximo de $-0,2 \mathrm{~V}$ (ou 0,6 V vs. NHE em pH 7,0). De acordo com alguns trabalhos descritos na literatura, ${ }^{126,127}$ nos quais reportam especificamente o comportamento eletroquímico de 
$\mathrm{NPs}-\mathrm{Fe}_{3} \mathrm{O}_{4}$ em diferentes tipos de eletrólito suporte, esse processo redox é característico da mudança do estado de oxidação dos íons de ferro (II) a ferro (III) presentes na estrutura cristalina de espinélio inverso das $\mathrm{NPs}_{-} \mathrm{Fe}_{3} \mathrm{O}_{4}$. Além disso, esse processo redox é dependente da difusão de espécies $\mathrm{H}^{+}$através dessa estrutura cristalina.

Figura 22- Voltamogramas cíclicos obtidos para o eletrodo de ouro (linhas pontilhadas em a, b, c e d) e para os filmes magneticamente induzidos de $\mathrm{NPs}_{-} \mathrm{Fe}_{3} \mathrm{O}_{4}$ (linhas pretas em a e d), $\mathrm{NPs}^{-}-\mathrm{Fe}_{3} \mathrm{O}_{4}-\mathrm{Au}$ (linhas vermelhas em b e d) e NPs- $\mathrm{Fe}_{3} \mathrm{O}_{4}$-Au funcionalizadas (linhas azuis em c e d). Eletrólito suporte: tampão fosfato de sódio $50 \mathrm{mmol} \mathrm{L}^{-1}, \mathrm{pH} 7,0$. Velocidade de varredura: $100 \mathrm{mV} \mathrm{s}^{-1}$.

a)

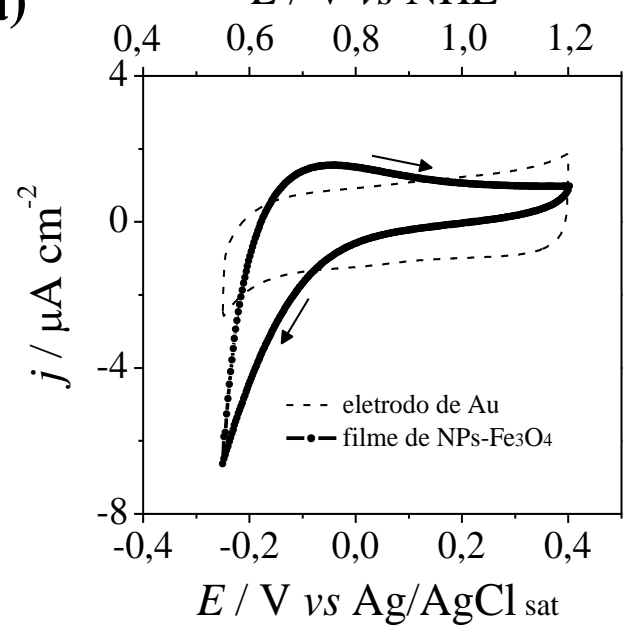

c)

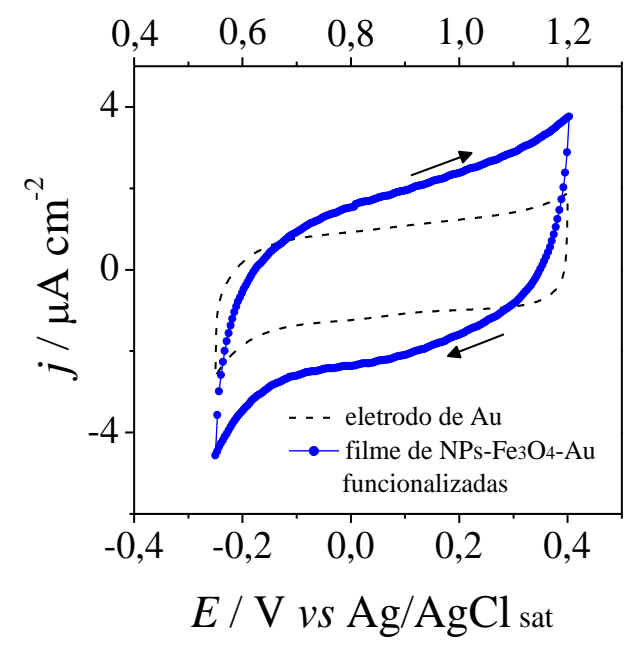

b)

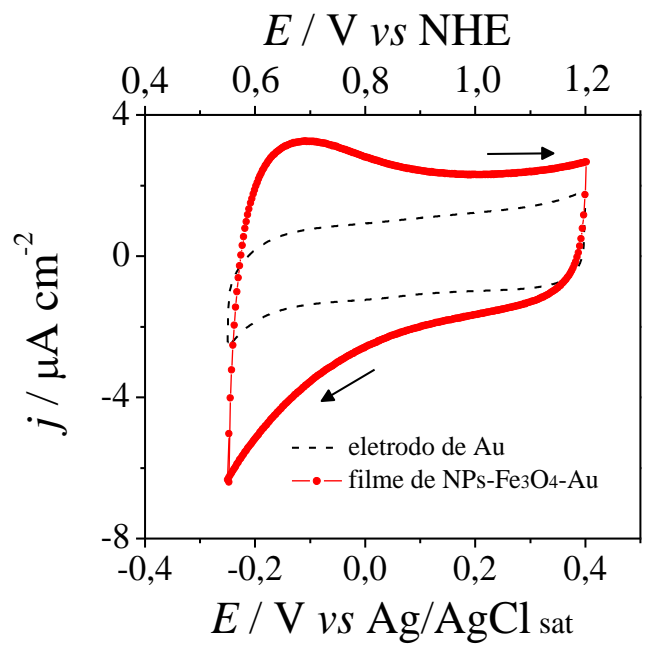

d)

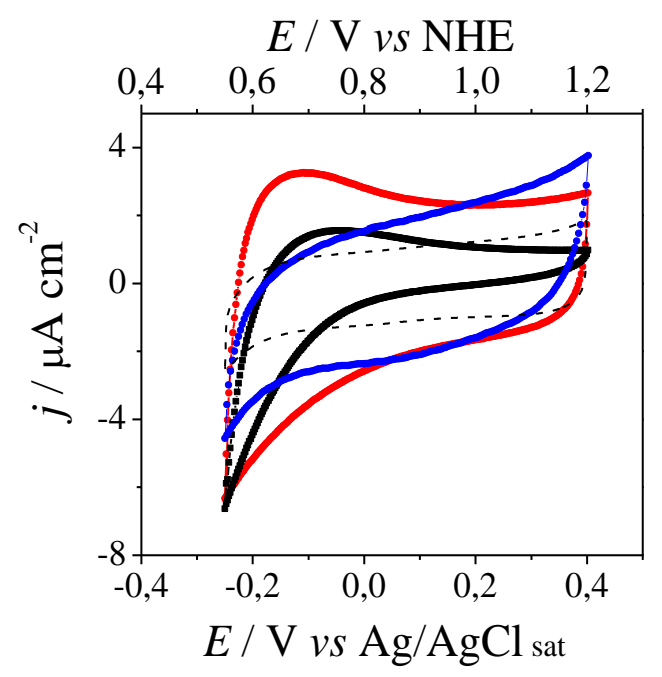

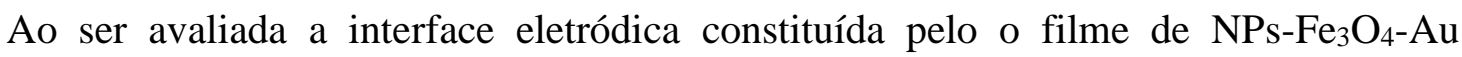
funcionalizadas, nota-se a presença de um perfil mais capacitivo quando comparada apenas ao eletrodo de ouro (Figura 22c). Ademais, o processo redox irreversível observado para os filmes de $\mathrm{NPs}-\mathrm{Fe}_{3} \mathrm{O}_{4}$ e $\mathrm{NPs}_{-}-\mathrm{Fe}_{3} \mathrm{O}_{4}-\mathrm{Au}$ não foi observado para esse caso. Isso evidência a passivação 
da superfície das $\mathrm{NPs}_{-}-\mathrm{Fe}_{3} \mathrm{O}_{4}-\mathrm{Au}$ após a etapa de funcionalização, evitando uma possível mudança de fase cristalina da superfície de óxido de ferro por meio da varredura do potencial

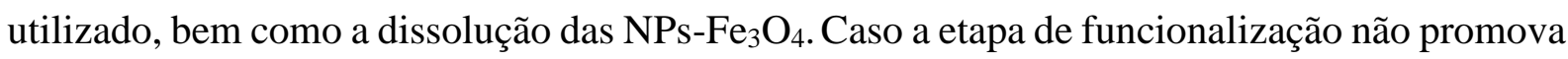
a passivação da superfície das $\mathrm{NPs}-\mathrm{Fe}_{3} \mathrm{O}_{4}$, a varredura da janela de potencial de 0,4 a 1,2 V vs. NHE (em pH 7,0) promoverá uma mudança de fase cristalina para maghemita $\left(\gamma-\mathrm{Fe}_{2} \mathrm{O}_{3}\right)$, como ilustrado no diagrama de Pourbaix referente ao sistema ferro- $\mathrm{H}_{2} \mathrm{O}$ (Figura 23). ${ }^{128}$

Figura 23- Diagrama de Pourbaix para o sistema ferro em água $\left(25^{\circ} \mathrm{C}, 1 \mathrm{~atm}\right)$. Para esse último, as únicas espécies consideradas em estado sólido são $\mathrm{Fe}, \mathrm{Fe}_{3} \mathrm{O}_{4} \mathrm{e} \gamma-\mathrm{Fe}_{2} \mathrm{O}_{3}$.

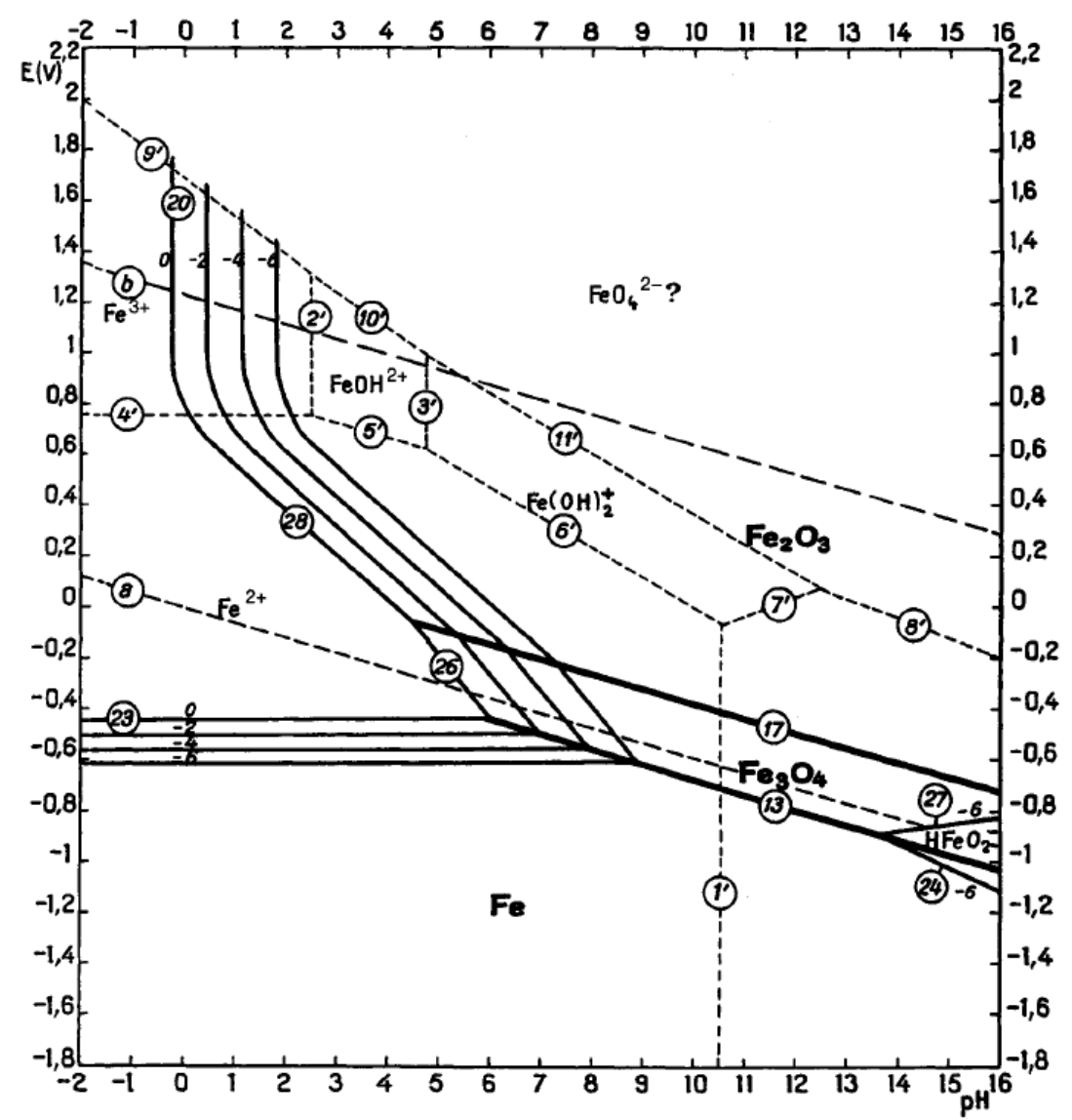

Fonte: Adaptação a partir de VERINK, E. D. Simplified procedure for constructing Pourbaix diagrams. Uhlig's Corrosion Handbook, p. 111-124, 2011.

\subsection{Controle magnético comutável da reação de transferência direta de elétrons do Cyt c}

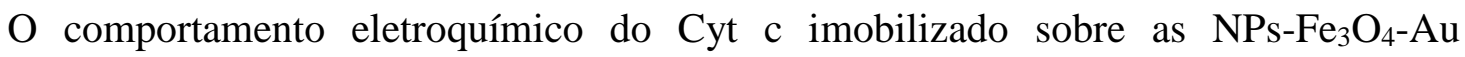
funcionalizadas foi avaliado após aplicação do modo switch on. Na Figura 24 são ilustrados os voltamogramas cíclicos para o eletrodo de ouro (linha preta pontilhada), solução de Cyt c $0,25 \mathrm{mg} \mathrm{mL}^{-1}$ (linha roxa) e para o composto $\mathrm{NPs}_{-} \mathrm{Fe}_{3} \mathrm{O}_{4}-\mathrm{Au}-\mathrm{Cyt} \mathrm{c}$ (linha vermelha). Para o 
eletrodo de ouro, nenhum processo redox foi observado dentro de janela de potencial trabalhada (de -0,25 a 0,4 V), enquanto para a eletroquímica da proteína em solução, observa-se apenas um processo redox com baixos valores de densidade de corrente referente a redução do Cyt c que se encontra no seu estado oxidado. Por outro lado, quando aplicado o modo switch on (veja o esquema ilustrativo na Figura 6), foram estabelecidas condições de fluxo por convecção forçada, ${ }^{129}$ aumentando o transporte de massa do composto $\mathrm{NPs}_{-}-\mathrm{Fe}_{3} \mathrm{O}_{4}$ - $\mathrm{Au}$-Cyt c em direção a superfície eletródica. Quando comparado ao perfil da proteína em solução, o modo switch on faz com que uma maior quantidade de Cyt c participe dos processos eletroquímicos, resultando no aumento dos valores de densidade de corrente. Para esse último, observa-se a presença de um par redox bem definido e quase reversível, indicando que a reação de transferência direta de elétrons foi estabelecida entre o grupo prostético heme e a superfície do eletrodo de ouro. Além disso, os potenciais de pico anódico $\left(E_{\mathrm{pa}}\right)$ e catódico $\left(E_{\mathrm{pc}}\right)$ localizados 0,14 e $0,00 \mathrm{~V}$ (vs. $\left.\mathrm{Ag} / \mathrm{AgCl}_{\text {sat }}\right)$ apresentam uma separação de pico $\left(\Delta E_{\mathrm{p}}\right)$ de $140 \mathrm{mV}$, a uma velocidade de $100 \mathrm{mV} \mathrm{s}^{-1}$.

Figura 24- Voltamogramas cíclicos obtidos para o eletrodo de ouro (linha preta pontilhada), solução de Cyt c $0,25 \mathrm{mg} \mathrm{mL}^{-1}$ (linha roxa) e para o composto $\mathrm{NPs}_{-}-\mathrm{Fe}_{3} \mathrm{O}_{4}-\mathrm{Au}-\mathrm{Cyt}$ c quando aplicado o modo switch on (linha vermelha). Eletrólito suporte: tampão fosfato de sódio $50 \mathrm{mmol} \mathrm{L}^{-1}, \mathrm{pH} 7,0$. Velocidade de varredura: $100 \mathrm{mV} \mathrm{s}^{-1}$.

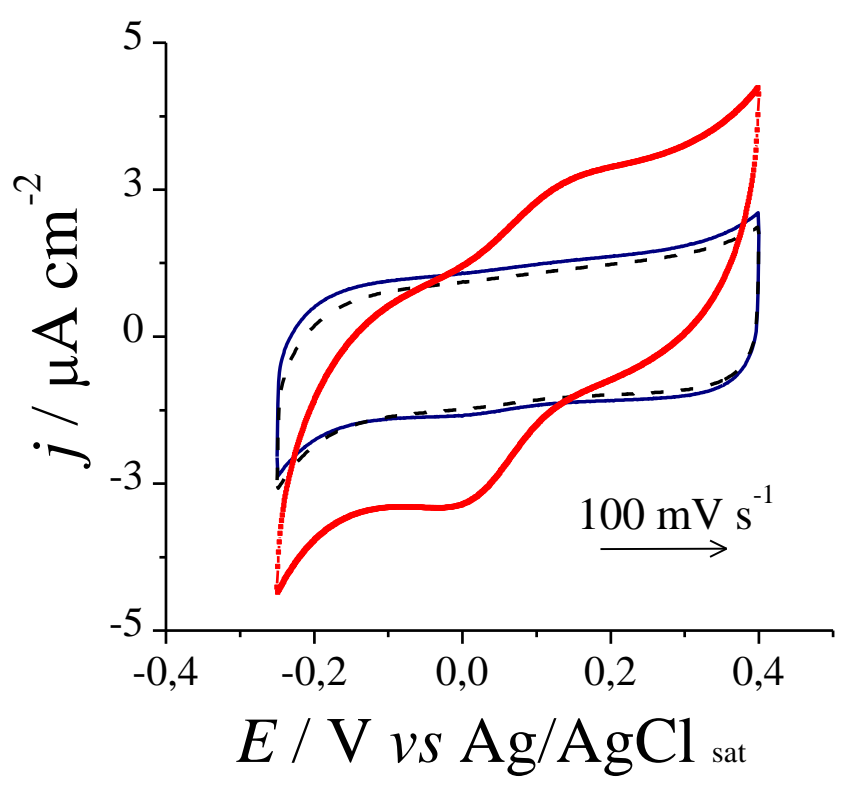


Com o aumento da variação da velocidade varredura empregando o modo switch on (Figura 25), obteve-se uma melhor compreensão a respeito do processo de transferência de direta de elétrons do Cyt c quando imobilizado na superfície das $\mathrm{NPs}_{-}-\mathrm{Fe}_{3} \mathrm{O}_{4}-\mathrm{Au}$ funcionalizadas. Conforme descrito anteriormente, com a deposição do composto $\mathrm{NPs}-\mathrm{Fe}_{3} \mathrm{O}_{4}$-Au-Cyt c na interface eletródica, na forma de um "filme proteico magneticamente induzido", tem-se a presença de um par redox bem definido e quase reversível. Para esse último, esperava-se um aumento linear dos valores de densidade de corrente com o aumento da velocidade de varredura. No entanto, mesmo após a aplicação do modo switch on, a transferência de elétrons na interface eletródica permanece governada por transporte de massa (Figura 25b). Esse perfil difusional pode estar relacionado à duas possíveis situações: (1) migração de íons do seio da solução para a interface eletródica a fim de compensar a formação de espécies carregadas eletricamente, mantendo assim a eletroneutralidade da mesma; ou (2) efeito da difusão de elétrons provenientes do grupo heme do Cyt c entre as camadas que compõem o filme proteico. De acordo com o trabalho desenvolvido por Crespilho e colaboradores, ${ }^{15}$ bem como um estudo que descreve o efeito da composição de filmes poliméricos na constante de difusão de elétrons provenientes de moléculas redox, ${ }^{130}$ o segundo caso mostra ser o mais provável.

Figura 25- (a) Voltamogramas cíclicos em diferentes velocidades de varredura $\left(50-1000 \mathrm{mV} \mathrm{s}^{-1}\right)$ para o composto $\mathrm{NPs}_{-} \mathrm{Fe}_{3} \mathrm{O}_{4}-\mathrm{Au}-\mathrm{Cyt}$ c empregando o modo switch on. (b) Gráfico da variação da densidade de corrente dos picos anódicos $\left(j_{\mathrm{pa}}\right)$ e catódicos $\left(j_{\mathrm{pc}}\right)$ em função da raiz quadrada da velocidade. Eletrólito suporte: tampão fosfato de sódio $50 \mathrm{mmol} \mathrm{L}^{-1}, \mathrm{pH} 7,0$.
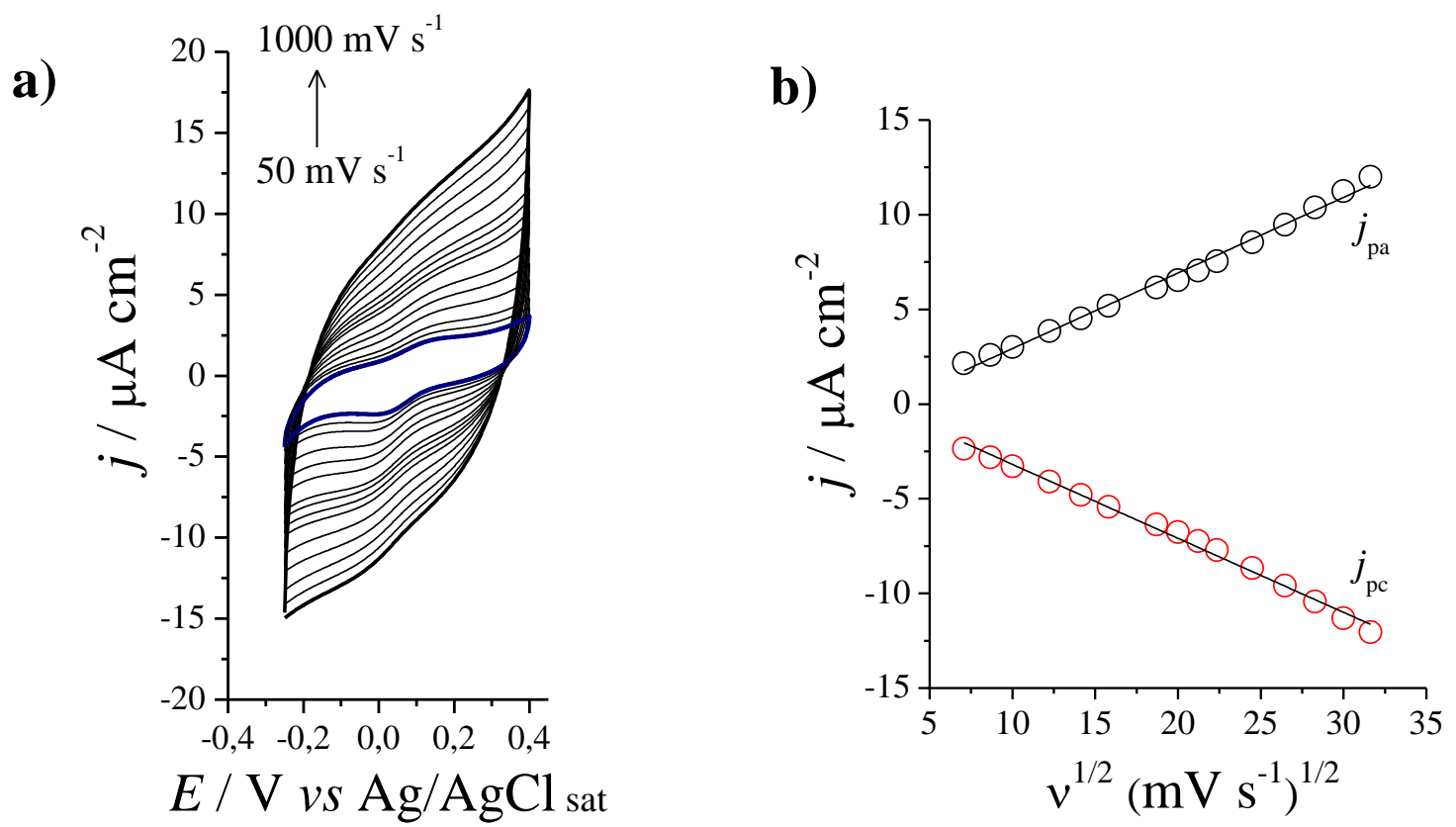
Por VC, avaliou-se também o controle magnético comutável da reação de transferência

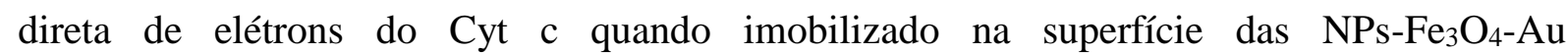
funcionalizadas. Para isso, como ilustrado na Figura 26, empregaram-se quatro ciclos comutativos (ciclos 1, 2, 3 e 4) obtidos após a permutação entre os modos switch on (linhas vermelha, verde, azul e cinza) e switch off (linhas pretas). Como resultado, após a permuta entre esses dois modos comutáveis, observa-se claramente o controle magnético da reação de transferência direta de elétrons do Cyt c sobre a interface eletródica. Porém, para os ciclos 2 e 3, ocorre um decaimento nos valores de densidade de corrente dos picos anódicos $\left(j_{\mathrm{pa}}\right)$ e catódicos $\left(j_{\mathrm{pc}}\right)$. Além disso, observa-se um desaparecimento da resposta eletroquímica do Cyt c quando empregado o modo switch on referente ao ciclo 4 (linha cinza).

Figura 26- Controle magnético comutável da reação de transferência direta de elétrons do Cyt c empregando os dois estados comutativos, os modos switch on (linhas vermelha, verde, azul e cinza) e switch off (linhas pretas). À direta, os gráficos em destaque mostram o decaimento dos valores de $j_{\mathrm{pa}} \mathrm{e}$ $j_{\mathrm{pc}}$ após a permuta entre esses dois modos comutáveis (pontos vermelho, verde, azul e cinza). Eletrólito suporte: tampão fosfato de sódio $50 \mathrm{mmol} \mathrm{L}^{-1}, \mathrm{pH} 7,0$. Velocidade de varredura: $100 \mathrm{mV} \mathrm{s}^{-1}$.
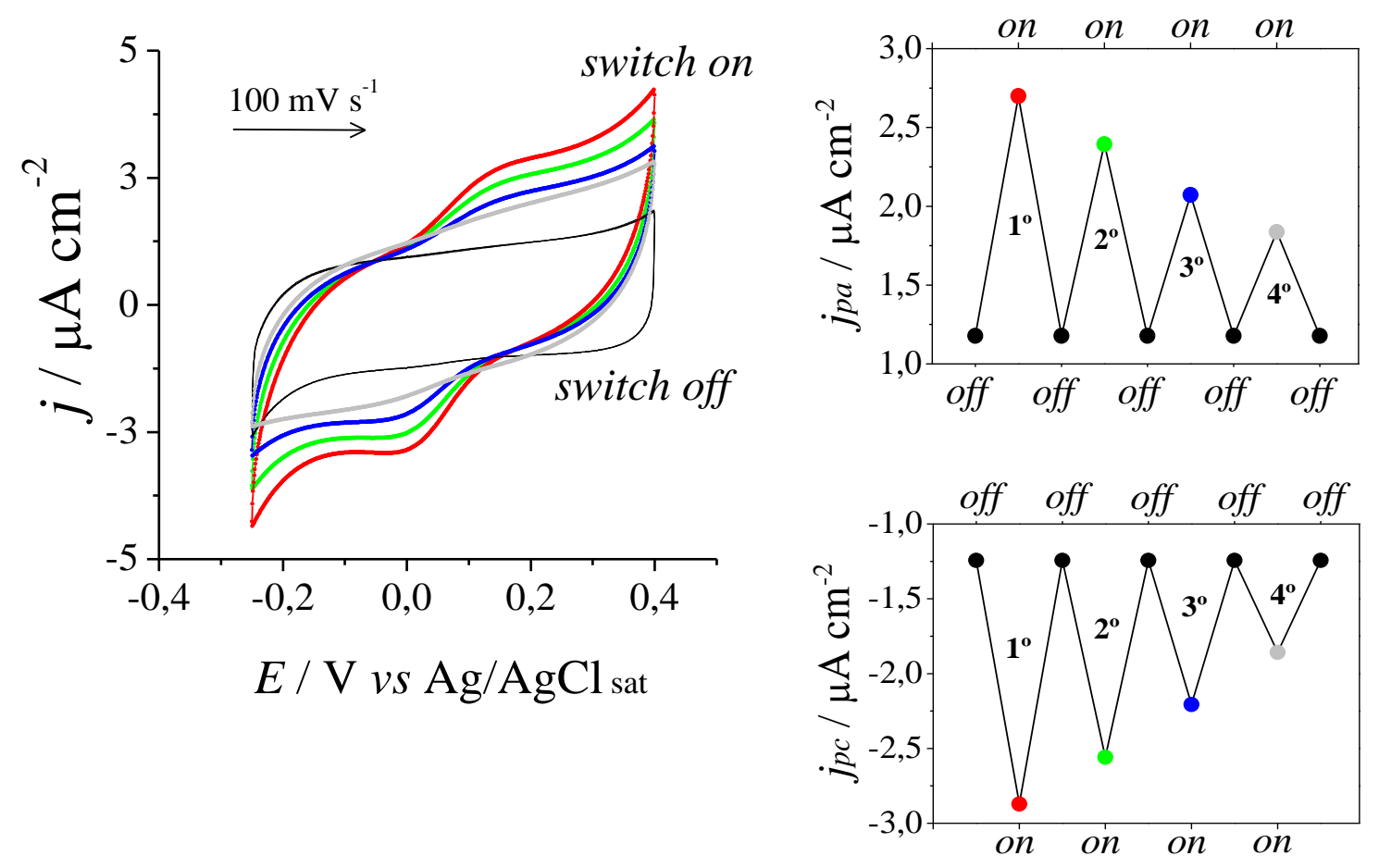

O decaimento nos valores de densidade de corrente dos picos anódicos $\left(j_{\mathrm{pa}}\right)$ e catódicos $\left(j_{\mathrm{pc}}\right)$ após a permuta entre os modos switch on e switch off (ciclos 2 e 3), bem como o desaparecimento do processo redox durante o ciclo 4, podem estar associados aos seguintes casos: mudança conformacional na estrutura terciara do citocromo c, lixiviação dessa proteína redox da superfície das $\mathrm{NPs}-\mathrm{Fe}_{3} \mathrm{O}_{4}-\mathrm{Au}$ funcionalizadas ou passivação do eletrodo de trabalho. 
Embora não conclusivo, experimentos mais detalhados precisam ser realizados a fim de melhorar o controle magnético comutável da reação de transferência direta de elétrons do

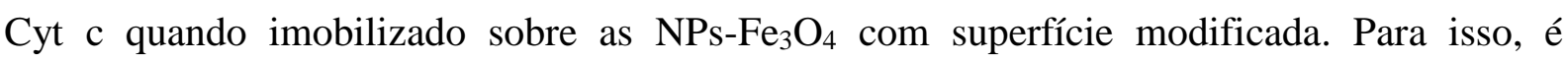
necessário que sejam esclarecidos os reais fatores que contribuem para a natureza do comportamento eletroquímico do Cyt c. Dentre esses, tem-se a influência do processo de imobilização na disposição na estrutura terciária do Cyt c sobre as $\mathrm{NPs}_{3}-\mathrm{Fe}_{3} \mathrm{O}_{4}-\mathrm{Au}$ funcionalizadas, permitindo que o grupo prostético heme fique exposto para participar da transferência direta de elétrons sobre uma determinada superfície eletródica. Além disso, para esse processo de transferência de elétrons, torna-se necessário avaliar a influência das NPs-Au, nas quais fazem parte do revestimento metálico presente sobre a superfície das $\mathrm{NPs}^{-} \mathrm{Fe}_{3} \mathrm{O}_{4}$. 


\section{Conclusão}

$\mathrm{NPs}-\mathrm{Fe}_{3} \mathrm{O}_{4}$ decoradas com NPs-Au (NPs- $\mathrm{Fe}_{3} \mathrm{O}_{4}-\mathrm{Au}$ ) foram obtidas com sucesso utilizando as duas rotas de síntese propostas neste estudo, modificações in situ e ex situ. Analisando as imagens de MET, observaram-se que os revestimentos metálicos obtidos por meio dessas duas modificações apresentaram NPs-Au quase monodispersas com um diâmetro médio em torno de $3 \mathrm{~nm}$. Além disso, por meio da modificação ex situ, NPs-Au foram depositadas de forma mais homogênea sobre a superfície das $\mathrm{NPs}_{-}-\mathrm{Fe}_{3} \mathrm{O}_{4}$. Dessa forma, $\mathrm{NPs}-\mathrm{Fe}_{3} \mathrm{O}_{4}-\mathrm{Au}$ por meio da modificação ex situ foram escolhidas para serem utilizadas como plataformas para imobilização do Cyt c. Para isso, as $\mathrm{NPs}_{-}-\mathrm{Fe}_{3} \mathrm{O}_{4}-\mathrm{Au}$ foram funcionalizadas com grupos amino e carboxílicos após a modificação de sua superfície utilizando moléculas de cisteína, enquanto a utilização do glutaraldeído como agente de entrecruzamento permitiu a imobilização do Cyt c sobre as $\mathrm{NPs}_{-}-\mathrm{Fe}_{3} \mathrm{O}_{4}-\mathrm{Au}$ funcionalizadas, levando a obtenção do composto $\mathrm{NPs}-\mathrm{Fe}_{3} \mathrm{O}_{4}-\mathrm{Au}-\mathrm{Cyt}$ c. Por FTIR, verificou-se que o espectro das $\mathrm{NPs}^{-} \mathrm{Fe}_{3} \mathrm{O}_{4}-\mathrm{Au}$ funcionalizadas apresenta um perfil similar ao da cistina comercial quando essa se encontra na sua forma zwitteriônica. Isso comprova a existência de cistina adsorvida sobre a superfície das $\mathrm{NPs}-\mathrm{Fe}_{3} \mathrm{O}_{4}-\mathrm{Au}$ após sua modificação empregando moléculas de cisteína. Também, por FTIR, confirmou-se a presença do Cyt c imobilizado sobre as $\mathrm{NPs}_{-}-\mathrm{Fe}_{3} \mathrm{O}_{4}-\mathrm{Au}$ funcionalizadas após a reação de reticulação. Para esse último, a massa de Cyt c imobilizada em $10 \mathrm{mg}$ de $\mathrm{NPs}-\mathrm{Fe}_{3} \mathrm{O}_{4}-\mathrm{Au}$ funcionalizadas foi de aproximadamente $0,23 \mathrm{mg}$.

$\mathrm{O}$ comportamento eletroquímico do Cyt c imobilizado sobre as $\mathrm{NPs}^{-} \mathrm{Fe}_{3} \mathrm{O}_{4}-\mathrm{Au}$ funcionalizadas ( $\mathrm{NPs}-\mathrm{Fe}_{3} \mathrm{O}_{4}-\mathrm{Au}-\mathrm{Cyt} \mathrm{c}$ ) foi avaliado por VC após aplicação do modo switch on. Para esse último, quando comparado ao perfil da proteína em solução, o modo switch on faz com que uma maior quantidade de Cyt c participe dos processos eletroquímicos, resultando no aumento dos valores de densidade de corrente. Além disso, observa-se a presença de um par redox bem definido e quase reversível, indicando que a reação de transferência direta de elétrons foi estabelecida entre o grupo prostético heme do Cyt c e a superfície do eletrodo de ouro. Com o aumento da variação da velocidade varredura empregando o modo switch on, nota-se que o processo de transferência de elétrons na interface eletródica é limitado por transporte de massa. Por fim, o controle magnético comutável da reação de transferência direta de elétrons do Cyt c, quando imobilizado na superfície das $\mathrm{NPs}-\mathrm{Fe}_{3} \mathrm{O}_{4}-\mathrm{Au}$ funcionalizadas, foi obtido após a permuta entre os modos comutáveis switch on e switch off. Para esse último, com a subsequente utilização desses dois modos comutáveis, nota-se um decaimento nos valores de 
densidade de corrente dos picos anódicos e catódicos e, em seguida, o desaparecimento da resposta eletroquímica do Cyt c.

Embora não conclusivo, experimentos mais detalhados precisam ser realizados a fim de melhorar o controle magnético comutável da reação de transferência direta de elétrons do Cyt c quando imobilizado sobre $\mathrm{NPs}_{-} \mathrm{Fe}_{3} \mathrm{O}_{4}$ com superfície modificada. Para isso, é preciso que seja esclarecido os reais fatores que contribuem para a natureza do comportamento eletroquímico do Cyt c. Dentre entre esses fatores, tem-se a influência do processo de imobilização na disposição da estrutura terciária do Cyt c sobre as $\mathrm{NPs}_{-}-\mathrm{Fe}_{3} \mathrm{O}_{4}-\mathrm{Au}$ funcionalizadas, permitindo que o grupo prostético heme fique exposto para participar da transferência direta de elétrons sobre uma determinada superfície eletródica. Além disso, para esse processo de transferência de elétrons, torna-se necessário avaliar a influência das NPs-Au, nas quais fazem parte do revestimento metálico presente sobre a superfície das $\mathrm{NPs}-\mathrm{Fe}_{3} \mathrm{O}_{4}$. 


\section{CAPÍTULO II}

Captura e transferência de nanocages bimetálicos para obtenção de padrões de litografia magnética 


\section{Introdução}

\subsection{Considerações Gerais: Litografia Magnética}

Durante várias décadas a técnica de litografia tem sido utilizada para criar padrões litográficos com dimensões de tamanho que vão desde alguns nanômetros até dezenas de milímetros. Esses, por sua vez, são empregados diretamente na construção de chips e circuitos integrados, contribuindo para o desenvolvimento da micro e nanoeletrônica. Por meio da combinação da técnica de litografia com outros processos de tratamento de superfície, tais como deposição, etching ou topografia de alta resolução, podem ser obtidos padrões litográficos com complexas morfologias em micro e nanoescala. ${ }^{131}$

Normalmente, a técnica de litografia tem sido empregada com e sem o uso de máscaras litográficas. Por exemplo, existem três tipos de litografias que não empregam o uso de máscaras, sendo denominadas litografias de feixe de elétrons, ${ }^{132}$ de íons localizados ${ }^{133} \mathrm{e}$ litografia de varredura por sonda. ${ }^{134}$ Nesses casos, são obtidos apenas padrões litográficos nanométricos com morfologias arbitrárias. Por outro lado, as litografias que fazem o uso de máscaras são denominadas de fotolitografia, ${ }^{135}$ soft lithography, ${ }^{136}$ litografia em nanoimpressão ${ }^{137}$ e litografia magnética. ${ }^{138}$ Para essas litografias, tem-se como princípio básico a utilização de máscaras ou moldes para transferir simultaneamente inúmeros padrões litográficos sobre uma superfície de interesse com uma grande área geométrica, permitindo a obtenção de padrões com um alto rendimento. ${ }^{131}$

Dentre os tipos de litografia descritas acima e que empregam o uso de máscaras, a litografia magnética é a mais simples, pois utiliza como força motriz um campo magnético de valor constante. Basicamente, essa técnica se baseia na aplicação de um campo magnético sobre uma máscara metálica paramagnética denominada "máscara magnética", na qual se encontra posicionada atrás de um determinado substrato. Essa máscara é análoga a uma máscara de fotolitografia, ${ }^{135}$ além disso, define a distribuição espacial e o formato do campo magnético aplicado sobre o substrato utilizado. Para esse tipo de litografia, a segunda componente consiste na utilização de NPs magnéticas (por exemplo, $\mathrm{NPs}_{-}-\mathrm{Fe}_{3} \mathrm{O}_{4}$ ) que são depositadas sobre a superfície do substrato seguindo o perfil das linhas de campo induzidas pela a máscara magnética. ${ }^{138}$

A Figura 27 ilustra o aparato experimental utilizado na construção dos padrões de litografia magnética. Nessa ilustração, a máscara magnética, posicionada entre o substrato de 


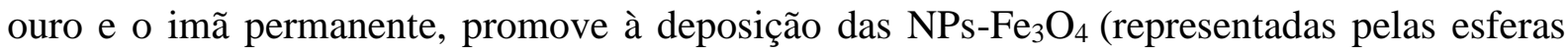
vermelhas) sobre a superfície metálica de ouro seguindo um padrão previamente estabelecido na forma de linhas paralelas. Geralmente, quando a máscara magnética se encontra relativamente distante do substrato, o campo magnético que atua sobre a sua superfície do ouro enfraquece. Isso induz a deposição de padrões de $\mathrm{NPs}-\mathrm{Fe}_{3} \mathrm{O}_{4}$ com perfis mais estreitos do que a espessura das linhas que compõem a máscara magnética. ${ }^{138}$

Figura 27- Aparato experimental utilizado na construção de padrões litográficos por meio das litografias magnéticas positiva e negativa.

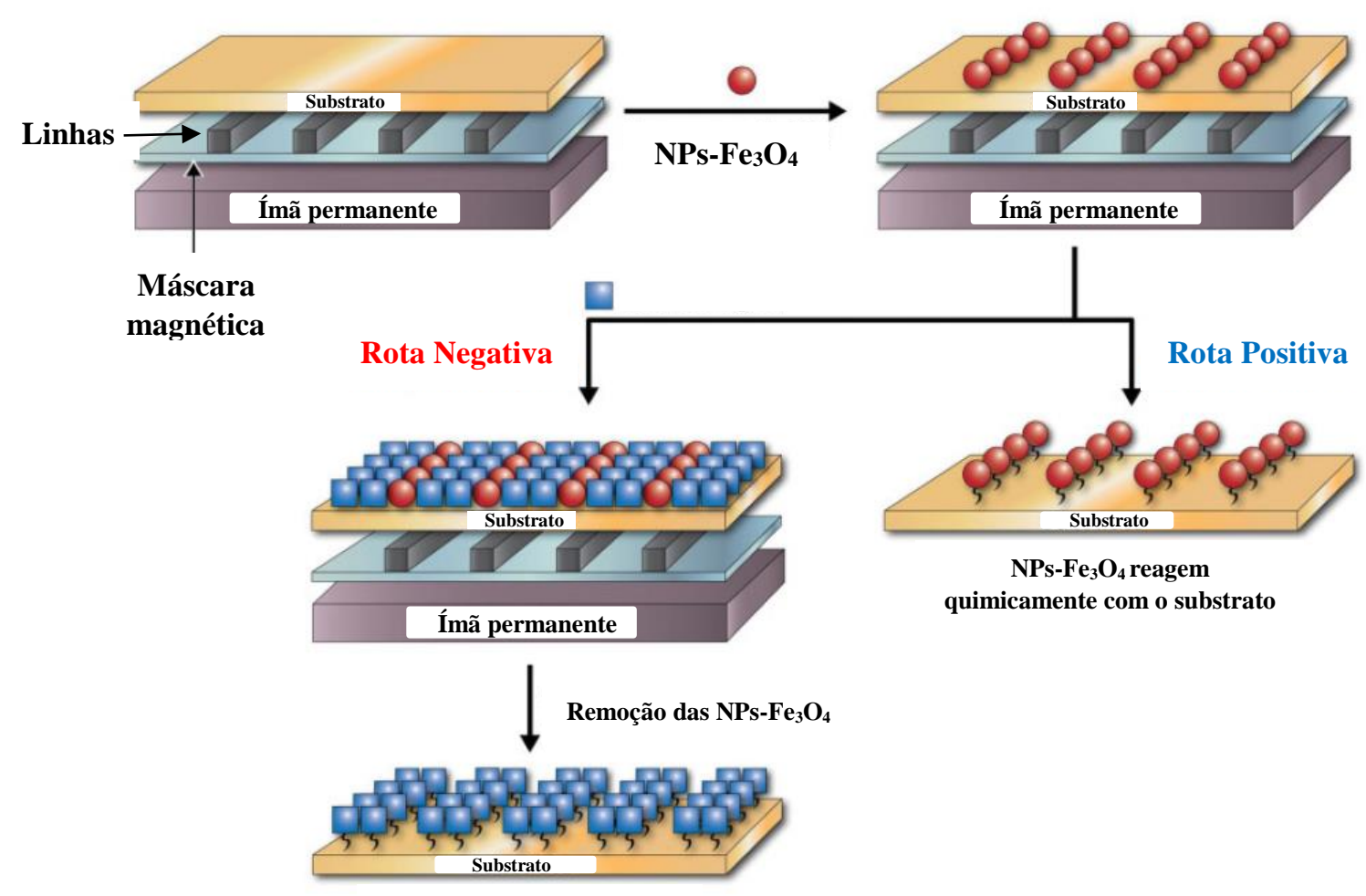

Fonte: Adaptação a partir de BARDEA, A.; NAAMAN, R. Magnetolithography: From Bottom-Up Route to High Throughput. Small, v. 5, n. 3, p. 316-31, 2009.

Para o aparato experimental ilustrado na Figura 27, um campo magnético constante é induzido sobre a superfície do substrato de ouro na presença de um ímã permanente e da máscara magnética. Dessa forma, a força aplicada sobre as $\mathrm{NPs}_{-}-\mathrm{Fe}_{3} \mathrm{O}_{4}$ que se encontram próximas ao substrato é representada pela equação 2 :

$$
F=\Delta x V(\nabla B) B \mu_{0}^{-1}
$$


onde $B$ é a densidade de fluxo magnético (tesla), $\Delta x$ é a diferença de suscetibilidade magnética entre um objeto e a sua vizinhança (de $10^{3}$ a $10^{5} \mathrm{~m}^{-3}$ para materiais paramagnéticos no ar), $V$ é o volume de uma única nanopartícula de magnetita $\left(\sim 1 \times 10^{-19} \mathrm{~cm}^{3}\right.$ para uma partícula de $10 \mathrm{~nm}$ de diâmetro) e $\mu_{0}$ é a constante de permeabilidade no vácuo. A equação 2 sugere que as $\mathrm{NPs}-\mathrm{Fe}_{3} \mathrm{O}_{4}$ devem ser atraídas e, em seguida, depositadas sobre a superfície do substrato de ouro de acordo com o gradiente do campo magnético. Além disso, a força atuante sobre essas NPs é maior com o aumento do seu volume, portanto, a força que atua sobre um aglomerado de $\mathrm{NPs}_{-}-\mathrm{Fe}_{3} \mathrm{O}_{4}$ será maior do que uma única nanopartícula isolada. ${ }^{138}$

Atualmente, existem poucos relatos descritos na literatura, nos quais reportam a utilização da técnica de litografia magnética. ${ }^{139-142}$ Basicamente, esses trabalhos descrevem a obtenção de padrões litográficos em microescala dispostos uniformemente sobre a superfície sólida de um determinado substrato. No estudo pioneiro datado de 2009, Naaman e colaboradores ${ }^{119}$ reportam a utilização de duas rotas (positiva e negativa) para a obtenção de padrões litográficos com diferentes morfologias, como ilustrado na Figura 27. Para o primeiro caso, rota positiva, $\mathrm{NPs}-\mathrm{Fe}_{3} \mathrm{O}_{4} \mathrm{com}$ um diâmetro de $10 \mathrm{~nm}$ apresentam uma interação química com um substrato de ouro modificado com uma monocamada de 1-4 benzendimethanethiol. Dessa forma, após a máscara magnética de cobalto induzir a distribuição espacial e o formato do campo magnético aplicado sobre o substrato, as $\mathrm{NPs}_{-}-\mathrm{Fe}_{3} \mathrm{O}_{4}$ foram imobilizadas quimicamente em locais pré-selecionados sobre a superfície de ouro. Por outro lado, na rota

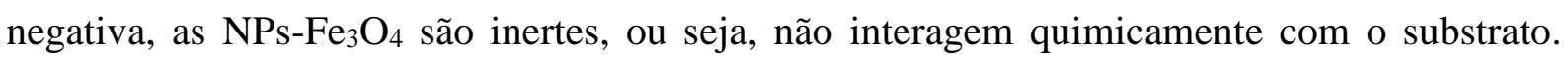
Portanto, uma vez depositadas sobre a superfície de interesse, as $\mathrm{NPs}_{-} \mathrm{Fe}_{3} \mathrm{O}_{4}$ bloqueiam o local onde uma outra espécie poderá interagir quimicamente com a camada de ouro. Por fim, após a deposição e a interação dessa segunda espécie, as $\mathrm{NPs}_{-}-\mathrm{Fe}_{3} \mathrm{O}_{4}$ são removidas do substrato, resultando em uma superfície padronizada com características negativas.

Nesse contexto, a segunda parte desta tese tem como principal motivação a utilização da técnica de litografia magnética para a obtenção de padrões constituídos por nanocages bimetálicos aglomerados em NPs- $\mathrm{Fe}_{3} \mathrm{O}_{4}$. Para isso, utilizou-se um aparato experimental similar ao reportado por Naaman e colaboradores (rota negativa), ${ }^{139}$ porém, a principal diferença é dada pelo o uso de uma máscara litográfica de cobre posicionada sobre a superfície de um determinado substrato sólido. Nesse caso, a máscara litográfica foi utilizada como anteparo para a deposição dos nanocages bimetálicos aglomerados em $\mathrm{NPs}-\mathrm{Fe}_{3} \mathrm{O}_{4}$, proporcionando uma significativa diferença quando comparado os perfis de alinhamento dos aglomerados 
depositados em torno e sobre as malhas que compõem a grade de cobre. Além disso, neste estudo foi descrito pela primeira vez a utilização de aglomerados de $\mathrm{NPs}^{-} \mathrm{Fe}_{3} \mathrm{O}_{4}$ para capturar nanoestruturas metálicas hollow (nanocages bimetálicos de $\mathrm{Au} / \mathrm{Ag}$ ) em suspensão aquosa e, em seguida, por meio um campo magnético de valor constante, transferi-los até a superfície da grade de cobre afim de obter padrões litográficos. Esse comportamento apresentado pelos aglomerados de $\mathrm{NPs}_{-} \mathrm{Fe}_{3} \mathrm{O}_{4}$ durante a captura das nanoestruturas metálicas hollow em suspensão aquosa foi denominado de adesivo magnético.

\subsection{Nanoestruturas metálicas hollow obtidas por substituição galvânica}

O controle fino durante a manipulação da morfologia de novas nanoestruturas metálicas é um dos maiores desafios em ciência dos materiais nos últimos anos. Dentro desse contexto, nanocristais de metais nobres que apresentam interiores hollow têm sido o foco de intensa investigação, pois possuem propriedades de superfície completamente diferentes quando comparadas aos nanocristais metálicos com morfologias convencionais, tais como nanoesferas, nanocubos e nanobastonetes. ${ }^{143,144}$

$\mathrm{Na}$ literatura, as principais metodologias empregadas para a obtenção de nanoestruturas metálicas hollow se baseiam em diferentes princípios, como o efeito Kirkendall, reação de substituição galvânica, ataque químico, decomposição em estado sólido e auto-organização de monocristais. ${ }^{145-156}$ Dentre esses diferentes princípios, a reação de substituição galvânica representa uma via extremamente simples e versátil. A força eletromotriz para essa reação é a diferença de potencial eletroquímico entre dois metais com diferentes potenciais redox, no qual um metal deve ser empregado como cátodo, na forma de um template de sacrifício, e o outro utilizado como ânodo, na forma de íons metálicos presentes em solução aquosa. ${ }^{157}$

Durante uma reação de substituição galvânica, a oxidação e a dissolução de um template de sacrifício são acompanhadas pela redução de outros tipos de íons metálicos em sua superfície. Por exemplo, para a reação entre nanocubos de Ag (utilizados geralmente como templete de sacrifício) e os íons de $\mathrm{AuCl}_{4}{ }^{-}$, uma vez que o potencial padrão de redução para as espécies de $\mathrm{AuCl}_{4}{ }^{-} / \mathrm{Au}\left(0,99 \mathrm{~V}\right.$ vs. SHE) é maior do que das espécies $\mathrm{Ag}^{+} / \mathrm{Ag}$ (0,8 V vs. SHE), os nanocubos de $\mathrm{Ag}$ tendem a ser oxidados por intermédio dos íons $\mathrm{AuCl}_{4}{ }^{-}$, assim como determinado pela reação redox representada na equação $3 .{ }^{157}$ 


$$
3 \mathrm{Ag}_{(\mathrm{s})}+\mathrm{AuCl}_{4}^{-}(\mathrm{aq}) \rightarrow 3 \mathrm{AgCl}_{(\mathrm{s})}+\mathrm{Au}_{(\mathrm{s})}+\mathrm{Cl}_{(\mathrm{aq})}^{-}
$$

Como resultado da reação de substituição galvânica, à medida que mais íons de $\mathrm{AuCl}_{4}^{-}$ são adicionados ao meio de reação, os nanocubos de Ag tendem a mudar a sua morfologia, levando a obtenção de nanoboxes e, em seguida, a formação de nanocages, ambos constituídos por uma liga metálica de Au/Ag. ${ }^{157}$ Quando comparados aos nanocubos de Ag, as nanoestrurutas metálicas hollow (nanoboxes e nanocages de $\mathrm{Au} / \mathrm{Ag}$ ) apresentam uma menor densidade, maior área de superfície e um shell poroso, no qual possibilita a sua utilização como plataformas estruturais para a construção de novos materiais multifuncionais. ${ }^{158}$

Uma das principais propriedades de superfície das nanoestruturas metálicas hollow é a ressonância de plasmon de superfície (SPR) ajustável. ${ }^{159,160}$ Em poucas palavras, a SPR é conceituada como o fenômeno óptico atribuído à oscilação coletiva dos elétrons presentes na banda de condução; fenômeno também responsável pela forte coloração das soluções coloidais metálicas. Normalmente, a banda de SPR referente às nanoestruturas metálicas hollow inclui ambas as componentes de absorção e espalhamento, e o seu perfil é dependente do tamanho e da morfologia dessas nanoestruturas. ${ }^{159-161}$ Ademais, a banda de SPR pode ser facilmente ajustável entre as regiões do visível e infravermelho próximo (NIR), controlando apenas o grau de substituição galvânica entre os dois elementos químicos que compõem a liga metálica presente nesse tipo de nanomaterial. ${ }^{157}$

A capacidade de ajustar facilmente a banda de SPR além do UV-Vis é promissora para aplicações biomédicas que procuram explorar as propriedades dispersão e absorção dessas nanoestruturas metálicas hollow, uma vez que o sangue e tecidos moles são relativamente transparentes entre 800 e $1200 \mathrm{~nm} .{ }^{157,162}$ Além disso, utilizado como antenas opticas ${ }^{163} \mathrm{em}$ estudos de espectroscopia de absorção no infravermelho intensificado por superfície (SEIRA) ${ }^{164}$ e espalhamento Raman intensificado por superfícies (SERS), ${ }^{165,166}$ esses materiais apresentam um grande potencial na intensificação dos modos vibracionais de moléculas orgânicas depositadas em sua superfície na forma de filmes finos. 


\section{Objetivos}

O principal objetivo deste estudo é obter padrões de litografia magnética utilizando

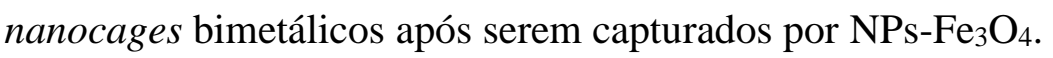

\subsection{Metas}

Abaixo estão descritas as principais metas alcançadas para a realização do objetivo aqui apresentado:

1) Sintetizar e caracterizar nanocubos de Ag obtidos por meio da adaptação do método de poliol;

2) Sintetizar e caracterizar nanocages bimetálicos de Au/Ag obtidos por meio da reação de substituição galvânica entre nanocubos de $\mathrm{Ag}$ e íons de $\mathrm{AuCl}_{4}{ }^{-}$;

3) Capturar os nanocages bimetálicos de Au/Ag presentes em suspensão aquosa após a sua aglomeração com $\mathrm{NPs}-\mathrm{Fe}_{3} \mathrm{O}_{4}$;

4) Transferir e depositar, por meio de um campo magnético constante, os aglomerados de nanocages bimetálicos e $\mathrm{NPs}-\mathrm{Fe}_{3} \mathrm{O}_{4}$ sobre a superfície de uma máscara de cobre utilizada na construção de padrões de litografia magnética;

5) Caracterizar os padrões de litografia magnética empregando a técnicas de MEV e FEG-MEV.

6) Monitorar os modos vibracionais das moléculas de PVP adsorvidas sobre os nanocages bimetálicos de $\mathrm{Au} / \mathrm{Ag}$ afim de obter o mapeamento químico dos padrões de litografia magnética. 


\section{Procedimento experimental}

\subsection{Instrumentação}

Espectros de UV-Vis-NIR foram obtidos por meio de um espectrofotômetro Shimadzu UV-3600 de duplo feixe, empregando uma cubeta de quartzo com um caminho óptico de $1 \mathrm{~cm}$. As imagens de MET foram realizadas em um microscópio FEI Tecnai G2 F20 operado a $200 \mathrm{kV}$, enquanto as imagens de MEV e MEV-FEG foram obtidas por meio de um microscópio Hitachi S-4800 operado a 20 e $5 \mathrm{kV}$, respectivamente. Os espectros de FTIR foram obtidos no modo transmitância (janela de KBr), utilizando um espectrômetro Bruker Tensor 27 FT-IR, na região de 4000-400 $\mathrm{cm}^{-1}$, com resolução de $4 \mathrm{~cm}^{-1}$. Já os espectros de absorção e os mapas químicos de infravermelho foram obtidos em modo de reflectância difusa, empregando um microscópio de infravermelho Hyperion 3000, Bruker. Para a obtenção do mapeamento químico, empregou-se uma objetiva de 15x, além disso, utilizou-se como referência (branco) um espelho de ouro posicionado abaixo do substrato utilizado para deposição dos padrões de litografia magnética.

\subsection{Síntese dos nanocubos de Ag}

Nanocubos de Ag foram preparados empregando uma adaptação do método proposto por Liang e colaboradores. ${ }^{167}$ Para isso, primeiramente, preparam-se duas soluções estoque, sendo a primeira uma solução contendo $0,5 \mathrm{~g}$ de nitrato de prata $\left(\mathrm{AgNO}_{3}\right.$ 99,9999\%, Sigma-Aldrich) e $0,86 \mu \mathrm{g}$ de cloreto de cobre (II) dihidratado $\left(\mathrm{CuCl}_{2} .2 \mathrm{H}_{2} \mathrm{O} 99,9 \%\right.$, Wako) dissolvidos em 12,5 mL de 1,5-pentanodiol (PD 98\%, Acros Organics), e a segunda, uma solução contendo $25 \mathrm{~g}$ de polivinilpirrolidona (PVP Mw 55,000, Sigma-Aldrich) dissolvidos também em 12,5 mL de PD. Enquanto essas duas soluções estoque eram preparadas, manteve-se $20 \mathrm{~mL}$ de PD em banho de silicone a uma temperatura de $150{ }^{\circ} \mathrm{C}$. Depois, várias alíquotas oriundas dessas duas soluções estoque foram injetadas em PD aquecido utilizando diferentes intervalos de tempo, por exemplo: $500 \mu \mathrm{L}$ da solução $\mathrm{AgNO}_{3} / \mathrm{CuCl}_{2} \mathrm{em} \mathrm{PD}$ foram injetados a cada minuto, enquanto $250 \mu \mathrm{L}$ da solução de PVP em PD foram adicionados a cada 30 segundos. Após 6 minutos, o meio de reação apresentou uma coloração opaca, levando a obtenção de nanocubos de Ag em suspensão aquosa. 
Para a realização da próxima etapa, síntese das nanoestruturas metálicas hollow, os nanocubos de Ag foram decantados por centrifugação (4000 rpm) e, em seguida, lavados várias vezes com água ultrapura a fim de remover o excesso de PD e PVP em suspensão. Por fim, os nanocubos de Ag foram dispersos em $25 \mathrm{~mL}$ de água, levando a uma suspensão estoque com uma concentração comum de $1,48 \mathrm{mg} \mathrm{mL}^{-1}$ (valor determinado com o auxílio de uma microbalança de cristal de quartzo - QCM).

\subsection{Síntese dos nanoboxes e nanocages de Au/Ag}

Nanoboxes e nanocages de $\mathrm{Au} / \mathrm{Ag}$ foram preparados empregando uma reação de substituição galvânica entre nanocubos de $\mathrm{Ag}$ e os íons de $\mathrm{AuCl}_{4}{ }^{-1} \cdot{ }^{168}$ Para isso, primeiramente, $150 \mu \mathrm{L}$ da suspensão estoque de nanocubos de $\mathrm{Ag}(0,22 \mathrm{mg})$ foram adicionados a um balão de fundo chato contendo $5 \mathrm{~mL}$ de uma solução de PVP $1 \mathrm{mg} \mathrm{mL}^{-1}$. Essa solução foi mantida em aquecimento e sob agitação mecânica por 10 minutos. Em seguida, ao meio de reação, adicionaram-se diferentes alíquotas de uma solução $0,2 \mathrm{mmol} \mathrm{L}^{-1}$ de ácido tetracloroaúrico triidratado ( $\mathrm{HAuCl}_{4} .3 \mathrm{H}_{2} \mathrm{O} 99 \%$, Sigma-Aldrich) utilizando uma bomba seringa com uma taxa de fluxo de $45 \mathrm{~mL} \mathrm{~h}^{-1}$. Por exemplo, para a obtenção de nanoboxes de $\mathrm{Au} / \mathrm{Ag}$ (nanoesturutura intermediária observada antes da síntese dos nanocages bimetálicos), primeiramente, adicionaram-se $6 \mathrm{~mL}$ da solução de $\mathrm{HAuCl}_{4}$ 0,2 mmol L $\mathrm{L}^{-1}$, enquanto para obtenção dos nanocages, foram adicionados ao meio de reação $9 \mathrm{~mL}$ da solução precursora de íons $\mathrm{AuCl}_{4}$ Uma vez resfriados em temperatura ambiente, os nanoboxes e nanocages de $\mathrm{Au} / \mathrm{Ag}$ foram centrifugados, separadas do sobrenadante e, em seguida, lavados com uma solução saturada de cloreto de sódio $(\mathrm{NaCl} 99 \%$, Vetec) a fim de remover os cristais de cloreto de prata $(\mathrm{AgCl})$ remanescentes. Posteriormente, essas duas nanoestruturas metálicas hollow foram lavadas várias vezes com água para remover o excesso de $\mathrm{PVP}$ e $\mathrm{NaCl}$ e, finalmente, redispersas em 2,5 mL de água ultrapura. Após a redispersão dos nanocages bimetálicos de Au/Ag em água, obteve-se uma suspensão com concentração de $25 \mu \mathrm{g} \mathrm{mL}^{-1}$.

\subsection{Captura dos nanocages bimetálicos e preparo dos padrões de litografia magnética}

Para o preparo dos padrões de litografia magnética, utilizando aglomerados de nanocages bimetálicos e $\mathrm{NPs}-\mathrm{Fe}_{3} \mathrm{O}_{4}$, realizaram-se as 2 etapas descritas a abaixo: 
Etapa 1: Primeiramente, a partir da suspensão estoque de $\mathrm{NPs}^{-} \mathrm{Fe}_{3} \mathrm{O}_{4}$ descrita no capítulo I, preparou-se uma suspensão de baixa concentração $\left(50 \mu \mathrm{g} \mathrm{mL} \mathrm{m}^{-1}\right)$. Depois, uma alíquota contendo $500 \mu \mathrm{L}$ dessa suspensão $\left(25 \mu \mathrm{g}\right.$ de $\left.\mathrm{NP}-\mathrm{Fe}_{3} \mathrm{O}_{4}\right)$ foi adicionada em uma cubeta de polimetilmetacrilato (PMMA) contendo 2,5 $\mathrm{mL}$ de nanocages bimetálicos de $\mathrm{Au} / \mathrm{Ag}$ $(63,42 \mu \mathrm{g})$, levando à aglomeração e decantação dessas nanoestruturas metálicas hollow. Por fim, com o intuito de tornar esses dois materiais nanoestruturados dispersos em suspensão aquosa, a cubeta de PMMA foi imersa em banho de ultrassom por 10 minutos.

Etapa 2: No intuito de preparar os padrões de litografia magnética, primeiramente, empregou-se uma grade de cobre (300 mesh) como máscara litográfica. Para isso, essa máscara foi cuidadosamente fixada sobre o centro da superfície de um substrato sólido como uma área geométrica de 1,24 $\mathrm{cm}^{2}$. Em seguida, esse substrato, juntamente com a máscara litográfica, foi posicionado no interior da cubeta de PMMA contendo $3 \mathrm{~mL}$ da suspensão referente a mistura de nanocages bimetálicos e $\mathrm{NPs}_{-} \mathrm{Fe}_{3} \mathrm{O}_{4}$. Depois, um imã de ferro-neodímio-boro $(B=0,2 \mathrm{~T})$ foi posicionado atrás da máscara litográfica, permitindo que os aglomerados de nanocages bimetálicos e NPs- $\mathrm{Fe}_{3} \mathrm{O}_{4}$ fossem depositados sobre a mesma e, consequentemente, preenchendo os espaços vazios observados na malha que a compõe (à direita, na Figura 28, a imagem de microscopia óptica mostra a grade cobre utilizada como máscara litográfica, no qual cada espaço vazio originou um padrão litográfico com uma área aproximada de $3600 \mu \mathrm{m}^{2}$ ). Posteriormente, após a aplicação de um campo magnético por 2 horas, removeu-se todo o líquido presente no interior da cubeta e, em seguida, a mesma foi levada para uma câmara de secagem a vácuo por 4 horas. Por fim, retirou-se cuidadosamente a máscara litográfica, levando a formação de vários padrões litográficos dispostos sobre a superfície do ITO, no qual foi utilizado como substrato. A Figura 29 apresenta a ilustração esquemática referente à captura dos nanocages bimetálicos e preparo dos padrões de litografia magnética.

É importante mencionar que, por meio da metodologia descrita acima, os aglomerados formados por nanocages bimetálicos e $\mathrm{NPs}_{-} \mathrm{Fe}_{3} \mathrm{O}_{4}$ podem ser depositados em diferentes superfícies, tais como papel, ITO ou ouro. Neste estudo, a escolha do ITO como substrato para a construção dos padrões de litografia magnética é justificada pela sua versatilidade em diferentes aplicações, por exemplo, dispositivos ópticos e/ou eletroquímicos. Além disso, o mesmo apresenta um menor custo quando comparado ao substrato de ouro. 
Figura 28- (a) Grade de cobre de 300 mesh utilizada como máscara litográfica para a obtenção dos padrões de litografia magnética sobre a superfície de um substrato sólido. (b) Imagem de microscopia óptica (obtida com uma objetiva de 15x) mostrando os espaços vazios na malha que compõe a máscara litográfica. Para esse último, cada espaço vazio originou um padrão com uma área aproximada de $3600 \mu \mathrm{m}^{2}$.

a)

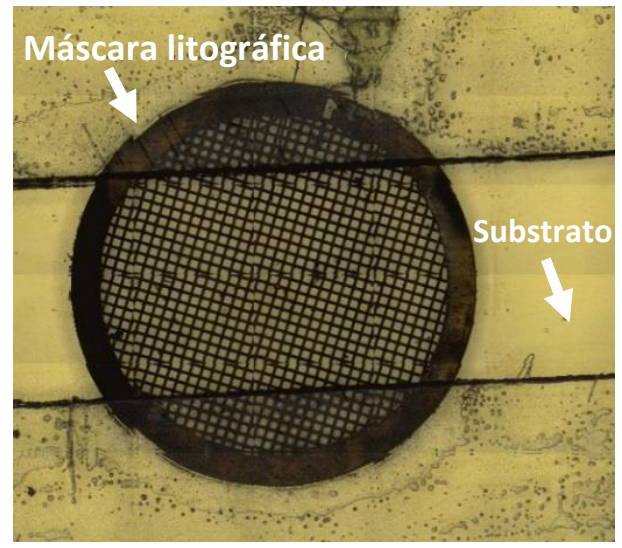

b)

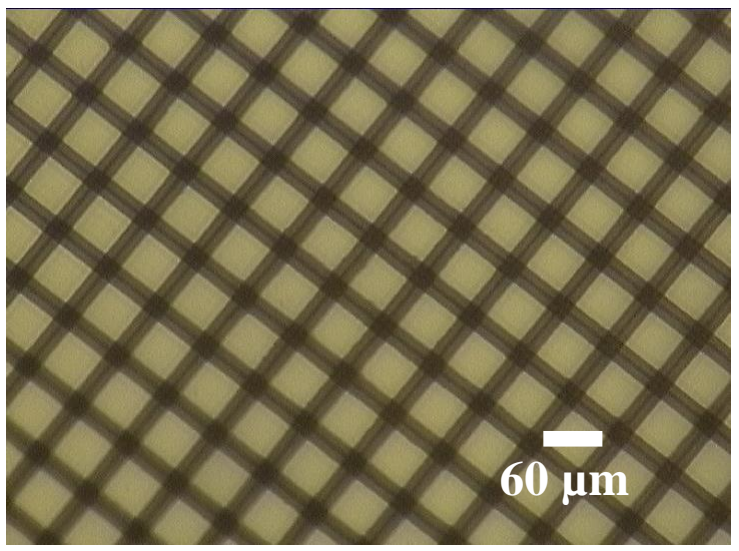

Fonte: Autoria própria

Figura 29- Ilustração esquemática da captura dos nanocages bimetálicos de $\mathrm{Au} / \mathrm{Ag}$ e preparo dos padrões de litografia magnética.

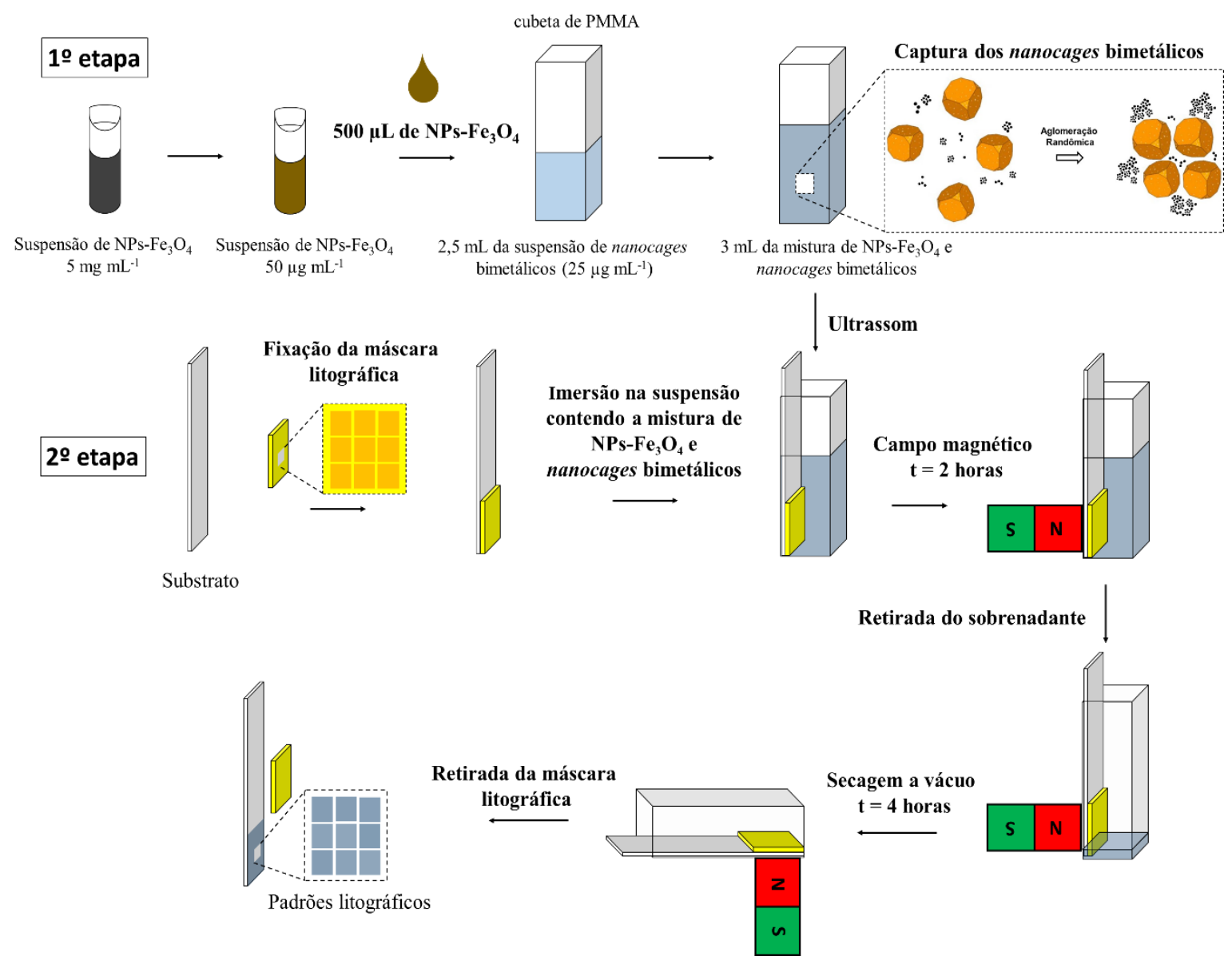

Fonte: Autoria própria 


\section{Resultados e discussão}

\subsection{Síntese e caracterização dos nanocubos de Ag}

$\mathrm{Na}$ literatura, a rota de síntese mais simples para a obtenção de nanopartículas esféricas de $\mathrm{Ag}$ (NPs-Ag) é dada pelo aquecimento da mistura de $\mathrm{AgNO}_{3}$ e citrato de sódio à $100{ }^{\circ} \mathrm{C} .{ }^{169}$ Já outro método bastante típico, descreve a preparação de NPs-Ag com um diâmetro médio de $3 \mathrm{~nm}$, no qual emprega $\mathrm{NaBH}_{4}$ como um agente redutor forte. ${ }^{170}$ No entanto, por meio dessas duas metodologias, geralmente são obtidas NPs metálicas não monodispersas. A fim de contornar essa problemática, Liang e colaboradores ${ }^{171}$ desenvolveram um método de alta eficiência (método poliol) para a síntese de nanoesferas de Ag monodispersas utilizando polietilenoglicol (PEG) como solvente e agente redutor, e PVP como agente estabilizante (esse último, permite que as NPs-Ag apresentem uma excelente dispersividade em meio aquoso) $)^{172}$ Posteriormente, o maior avanço relacionado à síntese de nanoestruturas de Ag foi estabelecido quando Sun e $\mathrm{Xia}^{173}$ empregaram o método de poliol para a preparação de nanocubos de Ag monodispersos com um tamanho médio de aresta de $175 \mathrm{~nm}$. Em seguida, em um estudo complementar, esses autores também reportaram a utilização do método poliol mediado por hidrossulfeto de sódio (NaHS) para a obtenção de nanocubos de Ag em larga escala. ${ }^{174}$ Recentemente, o método poliol mediado por uma única semente cristalina foi utilizado na preparação controlada de nanocubos de Ag com um tamanho entre 30 a 200 nm. ${ }^{175}$

Neste trabalho, os nanocubos de Ag utilizados como template de sacrifício para a síntese das nanoestruturas metálicas hollow (nanocages e nanoboxes bimetálicos de $\mathrm{Au} / \mathrm{Ag}$ ) foram sintetizados empregando uma adaptação do método poliol. ${ }^{167}$ Para isso, quando várias alíquotas oriundas das soluções de $\mathrm{AgNO}_{3}$ e PVP foram adicionadas ao meio de reação contendo PD aquecido à $150^{\circ} \mathrm{C}$, os íons $\mathrm{Ag}^{+}$foram reduzidos para $\mathrm{Ag}$ metálico pela ação do $\mathrm{PD}$, levando a formação de nanocubos de Ag com todas as seis faces laterais correspondentes aos planos (100). ${ }^{173}$ Além disso, foi adicionada uma pequena quantidade de $\mathrm{Cu}^{2+}$ ao meio de reação a fim de controlar a taxa de nucleação e a morfologia cúbica das nanoestruturas metálicas de Ag. Dessa forma, por meio dessa metodologia, obteve-se nanocubos de Ag monodispersos com um tamanho médio de aresta de 135,3 nm, como ilustrado nas imagens de MEV na Figura 30. 
Figura 30- Imagens de MEV em (a) e (b) ilustram nanopartículas monodispersas de Ag com uma morfologia cúbica. Em (c), tem-se o histograma e ajuste gaussiano da distribuição de tamanho médio para a aresta dos nanocubos de Ag de aproximadamente 135,3 nm.

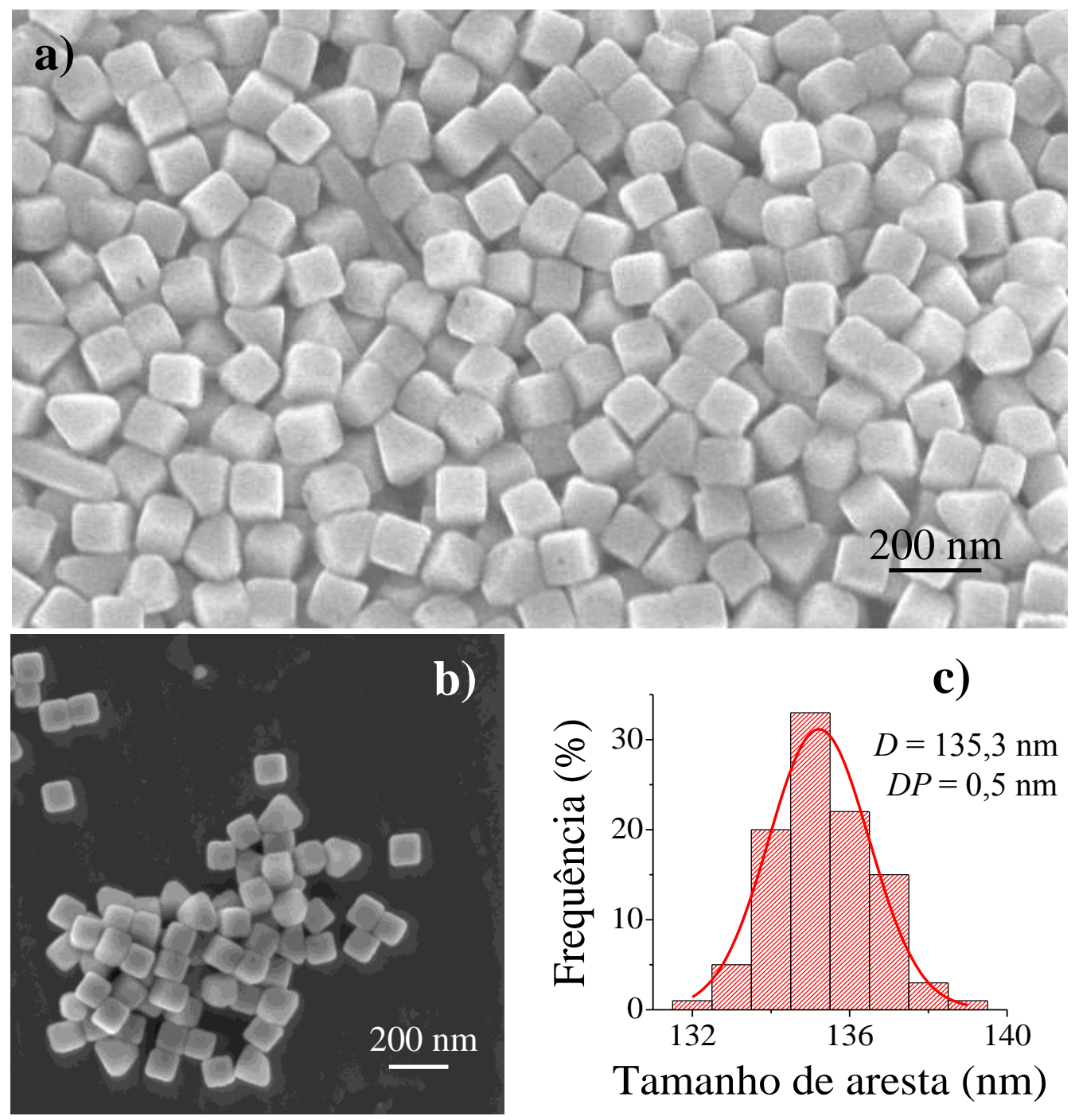

\subsection{Síntese e caracterização dos nanoboxes e nanocages bimetálicos de Au/Ag}

Como descrito anteriormente, a titulação de nanocubos de Ag com uma solução de $\mathrm{HAuCl}_{4}$ promove a obtenção de nanonoboxes e, em seguida, com o progresso da reação de substituição galvânica, tem-se a formação de nanocages. Para um melhor entendimento a respeito das etapas empregadas na obtenção de nanoboxes e nanocages de $\mathrm{Au} / \mathrm{Ag}$, veja a ilustração esquemática na Figura 31. 
Figura 31- Ilustração esquemática da obtenção de nanaboxes e nanocages bimetálicos de $\mathrm{Au} / \mathrm{Ag}$ empregando a reação de substituição galvânica.

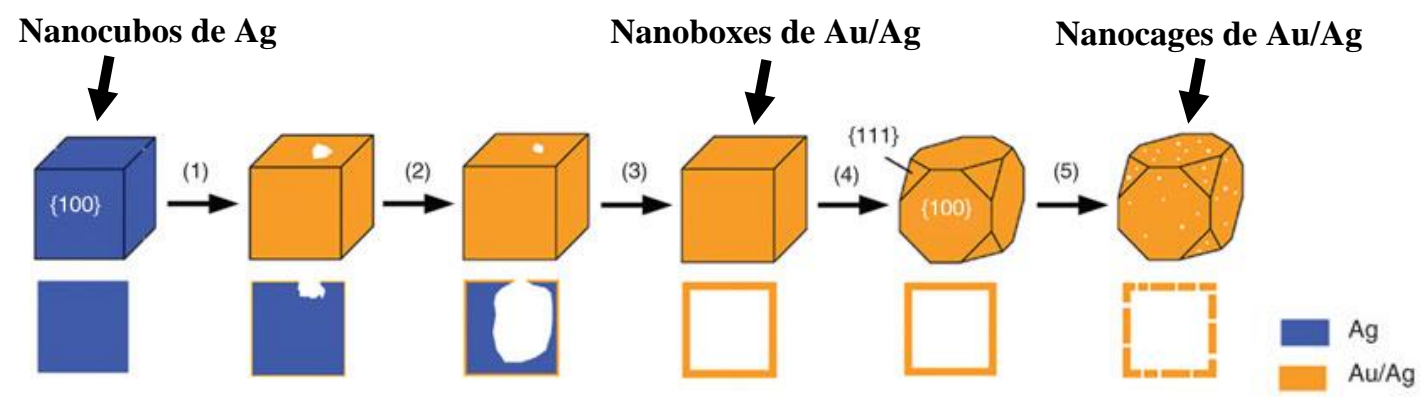

Fonte: Adaptação a partir de SKRABALAK, S. E.; AU, L.; LI, X.; XIA, Y. Facile synthesis of Ag nanocubes and Au nanocages. Nature Protocols, v. 2, n. 9, p. 2182-2190, 2007.

A Figura 32 ilustra as imagens de MEV e MET dos nanoboxes bimetálicos de $\mathrm{Au} / \mathrm{Ag}$ obtidos após a titulação dos nanocubos de $\mathrm{Ag}$ utilizando $6 \mathrm{~mL}$ da solução de $\mathrm{HAuCl}_{4}$ $0,2 \mathrm{mmol} \mathrm{L}^{-1}$. A reação de substituição galvânica entre nanocubos de $\mathrm{Ag}$ e os íons $\mathrm{AuCl}_{4}{ }^{-}$ocorre em meio aquoso a uma temperatura próxima da ebulição da água. À medida que os nanocubos

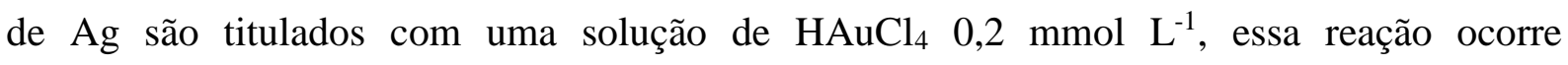
imediatamente em locais da superfície metálica que apresentam defeitos estruturais com uma elevada energia de superfície, por exemplo, defeitos do tipo pontual ou em linha. Em seguida, um orifício é formado em uma das seis faces de cada nanocubo, levando a oxidação e remoção dos átomos de Ag presentes no interior do mesmo (etapa 1). Esse processo é semelhante ao fenômeno de corrosão localizada, que geralmente ocorre em macroescala e leva a formação de pequenos orifícios em uma peça metálica. ${ }^{176}$ Para o caso dos nanocubos de $\mathrm{Ag}$, estudos computacionais têm demonstrado que, devido ao seu tamanho diminuto, em entorno de 50 a $150 \mathrm{~nm}$, é estatisticamente aceitável a presença de apenas um local de corrosão em sua superfície. ${ }^{177}$ 
Figura 32- Imagens de MEV (a) e MET (b) dos nanoboxes bimetálicos de Au/Ag.
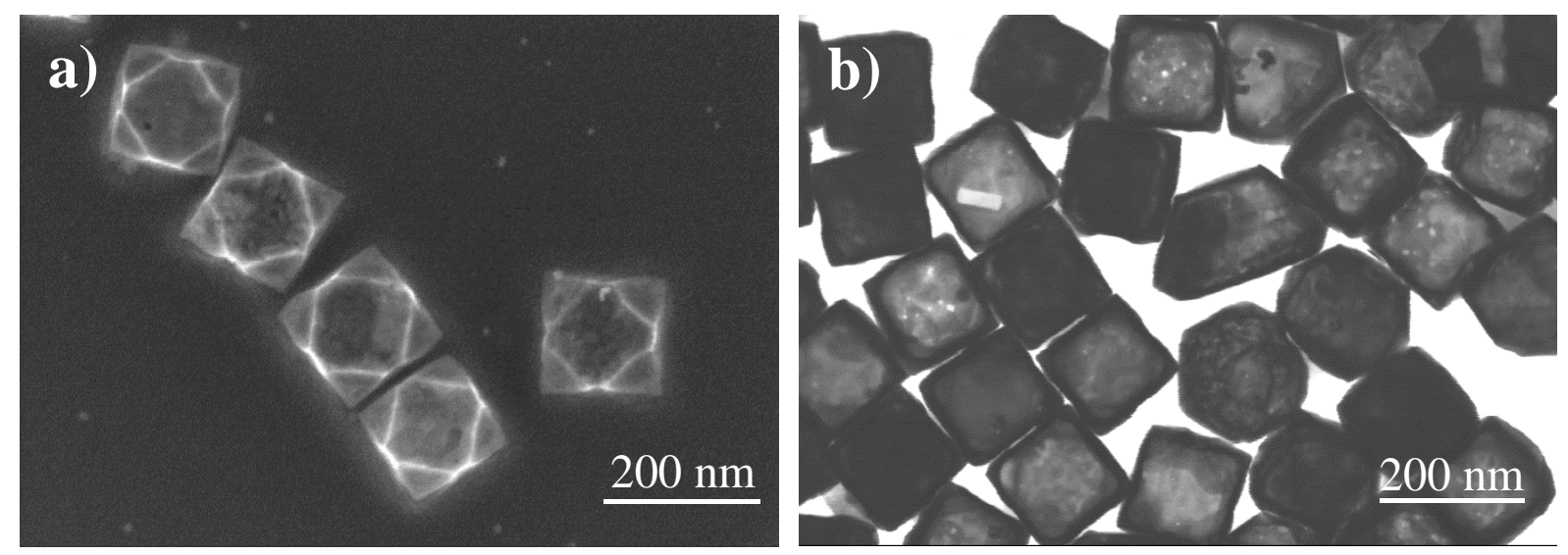

Com o andamento da reação de substituição galvânica, o local de corrosão continua a servir como ânodo, onde átomos internos de Ag são oxidados e os elétrons liberados podem facilmente migrar para a superfície, sendo posteriormente capturados pelos íons $\mathrm{AuCl}_{4}{ }^{-}$para gerar átomos de Au via redução. Por sua vez, os átomos de Au preferem nuclear e crescer na superfície dos nanocubos, pois $\mathrm{Ag}$ e $\mathrm{Au}$ metálico possuem uma estrutura cúbica de face centrada com os mesmos parâmetros cristalinos. ${ }^{157}$ Quanto mais solução de $\mathrm{HAuCl}_{4}$ é adicionada ao sistema reacional, o local de corrosão vai sendo gradualmente fechado por meio da combinação de vários processos de transferência de massa (por exemplo, efeito Kirkendall) que incluem a difusão lateral de átomos de Au em toda a superfície externa dos nanocubos de $\mathrm{Ag}$, e também a deposição direta em torno da borda do local de corrosão (etapa 2). ${ }^{178} \mathrm{Nesse}$ caso, a camada de Au depositada evita que o template de Ag seja totalmente dissolvido, levando a formação de um caixa cúbica com um interior vazio e composta por uma liga metálica de ouro e prata (etapa 3), como apresenta a imagem de MET na Figura 32b. Com o progresso da reação de substituição galvânica, tem-se a remoção seletiva dos átomos de Ag por meio do processo de dealloying, possibilitando a formação de vacâncias nas paredes dos nanoboxes. ${ }^{179}$ Após a formação dessas vacâncias, os nanoboxes tendem a reconstruir sua morfologia empregando um processo semelhante ao fenômeno de Ostwald ripening. ${ }^{177}$ Como resultado desse fenômeno, observa-se uma curvatura negativa em cada canto dessas nanoestruturas hollow (Figura 32a), levando a formação de um novo plano cristalino (111) - (etapa 4).

À medida que mais íons $\mathrm{AuCl}_{4}{ }^{-}$são adicionados ao meio de reação, mais átomos de $\mathrm{Ag}$ são removidos seletivamente da liga metálica que compõe os nanoboxes de $\mathrm{Au} / \mathrm{Ag}$ (processo de dealloying), levando a formação de mais defeitos estruturais e vacâncias em sua superfície. 
Essas vacâncias tendem a coalescer umas com as outras, proporcionando a formação de grandes poros nas paredes dos nanoboxes e a obtenção de nanocages bimetálicos (etapa 5). ${ }^{157} \mathrm{~A}$ Figura 33 ilustra as imagens de MET referente aos nanocages de Au/Ag obtidos por meio da titulação de nanoboxes com $3 \mathrm{~mL}$ de $\mathrm{HAuCl}_{4} 0,2 \mathrm{mmol} \mathrm{L}^{-1}$. Outra técnica utilizada para caracterizar os nanocages bimetálicos foi a espectroscopia de energia dispersiva de raios $\mathrm{X}$ (EDX), na qual permitiu a determinação de sua composição empregando o processo de mapeamento químico (dot mapping). Para esse último, verificou-se a presença dos principais elementos químicos envolvidos, tais como ouro e prata, sendo positivo para essas duas espécies metálicas (Figuras 33d e 33e). Além disso, para essas espécies, os valores em massa obtidos (valores normalizados) foram de 87,7 e $12,3 \%$, respectivamente.

Figura 33- Imagens de MET em (a) e (b) ilustram os nanocages de Au/Ag obtidos após a titulação de nanoboxes com $3 \mathrm{~mL}$ da solução de $\mathrm{HAuCl}_{4} 0,2 \mathrm{mmol} \mathrm{L} \mathrm{L}^{-1}$. Imagem de MET, em campo escuro, mostrando apenas um nanocages isolado (c). Mapeamento elementar (dot mapping) referente à nanoestrutura ilustrada em (c), destacando a presença dos principais elementos químicos que o constituem: ouro (d) e prata (e).
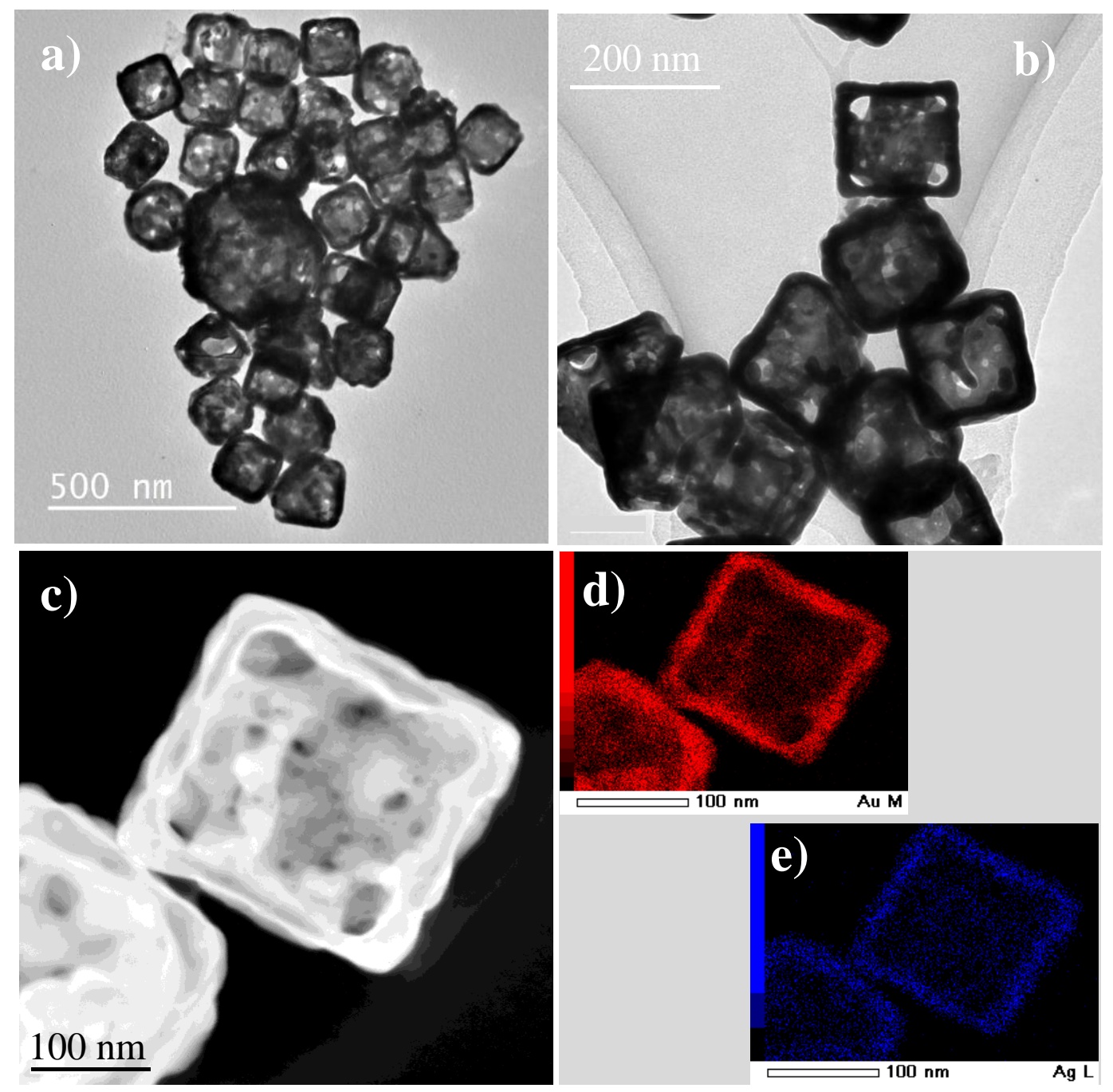
Por UV-Vis-NIR, avaliou-se o comportamento óptico dos nanoboxes e nanocages bimetálicos de $\mathrm{Au} / \mathrm{Ag}$ obtidos após a titulação de nanocubos de Ag com diferentes alíquotas da solução de $\mathrm{HAuCl}_{4}$ (Figura 34). Como descrito na parte experimental, para converter os templates de sacrifício em nanoboxes e nanocages de $\mathrm{Au} / \mathrm{Ag}$, foram adicionados, respectivamente, 6 e $9 \mathrm{~mL}$ da solução precursora dos íons $\mathrm{AuCl}_{4}^{-}$. Com isso, os espectros referentes aos nanoboxes e nanocages de $\mathrm{Au} / \mathrm{Ag}$, quando comparados ao espectro dos nanocubos de Ag, apresentam um deslocamento da banda de SPR para menores valores de energia (região do NIR). ${ }^{189,181}$ Esse deslocamento é do tipo red-shift de aproximadamente $580 \mathrm{~nm}$, sendo estimado a partir da posição do pico no espectro dos nanocubos de Ag com maior coeficiente de extinção (em $490 \mathrm{~nm}$ ).

Figura 34- Espectros de UV-Vis-NIR das suspensões de nanocubos de Ag (a), nanoboxes (b) e nanocages bimetálicos de $\mathrm{Au} / \mathrm{Ag}(\mathrm{c})$.

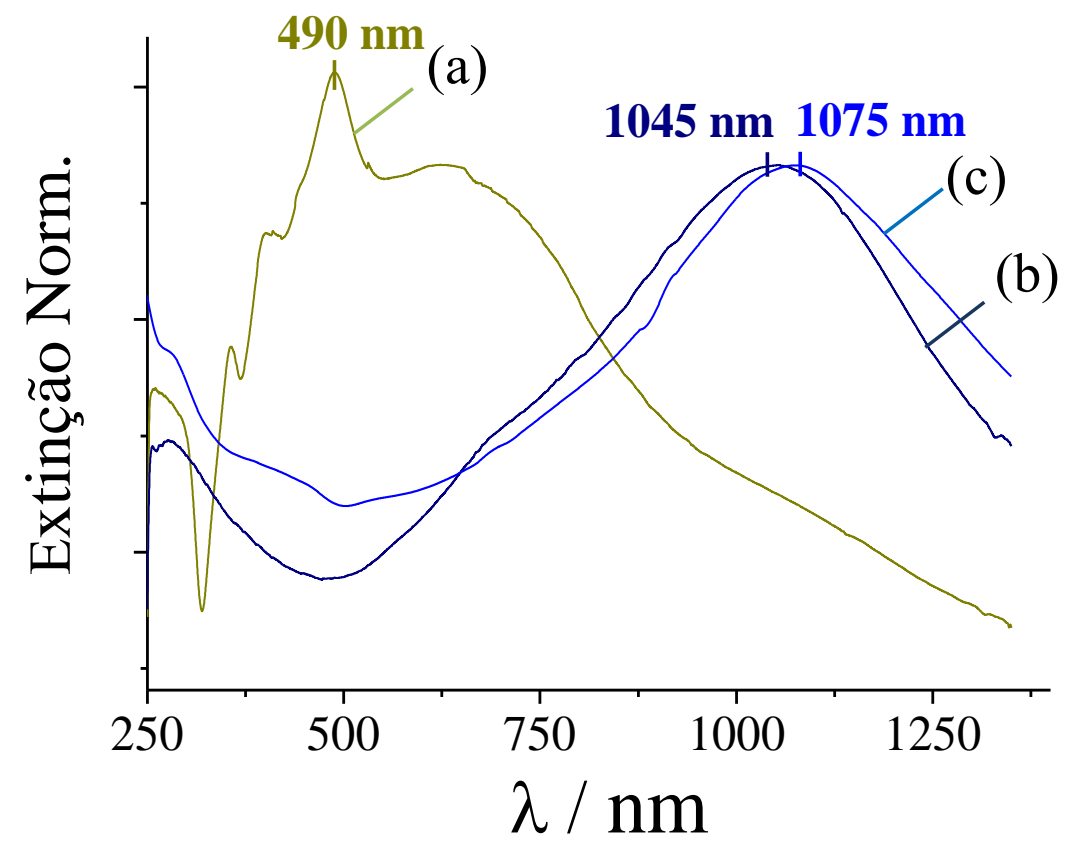

À medida que a espessura das paredes das nanoestruturas metálicas hollow diminui devido à formação de grandes vacâncias durante o processo de dealloying, a banda de SPR se move continuamente para regiões de maiores comprimentos de onda próximo a região do NIR. ${ }^{137,182}$ Portanto, a posição da banda SPR dos nanocages bimetálicos de Au/Ag é depende da espessura de suas paredes. Além disso, o aumento da porosidade contribui para a diminuição da intensidade da banda de SPR, como observado no espectro referente à suspensão dos nanoboxes bimetálicos $\mathrm{Au} / \mathrm{Ag} .{ }^{137,182}$ 


\subsection{Captura e transferência dos nanocages bimetálicos de Au/Ag}

Os nanocages bimetálicos de $\mathrm{Au} / \mathrm{Ag}$ foram capturados em suspensão aquosa após aglomeração com NPs-Fe ${ }_{3} \mathrm{O}_{4}$. Esse comportamento foi denominado de adesivo magnético. A Figura 35 mostra o esquema ilustrativo da aglomeração randômica em suspensão das

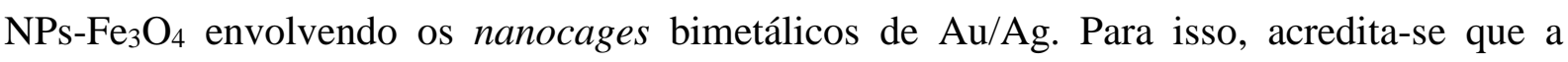
formação desses aglomerados ocorra principalmente devido à instabilidade coloidal desses dois tipos de materiais em suspensão aquosa. Para esse último, acredita-se que a maior contribuição seja proveniente das $\mathrm{NPs}-\mathrm{Fe}_{3} \mathrm{O}_{4}$, devido à ausência de moléculas de surfactantes ou polieletrólitos recobrindo a sua superfície. Além disso, $\mathrm{NPs}-\mathrm{Fe}_{3} \mathrm{O}_{4}$ com um tamanho médio de 11,9 $\mathrm{nm}$ possuem apenas um monodomínio magnético, portanto podem apresentar uma tendência natural de aglomeração devido ao fenômeno de superparamagnetismo. ${ }^{41,42}$

Figura 35- Esquema ilustrativo da captura dos nanocages bimetálicos de $\mathrm{Au} / \mathrm{Ag}$ em suspensão aquosa após aglomeração randômica com as $\mathrm{NPs}-\mathrm{Fe}_{3} \mathrm{O}_{4}$.
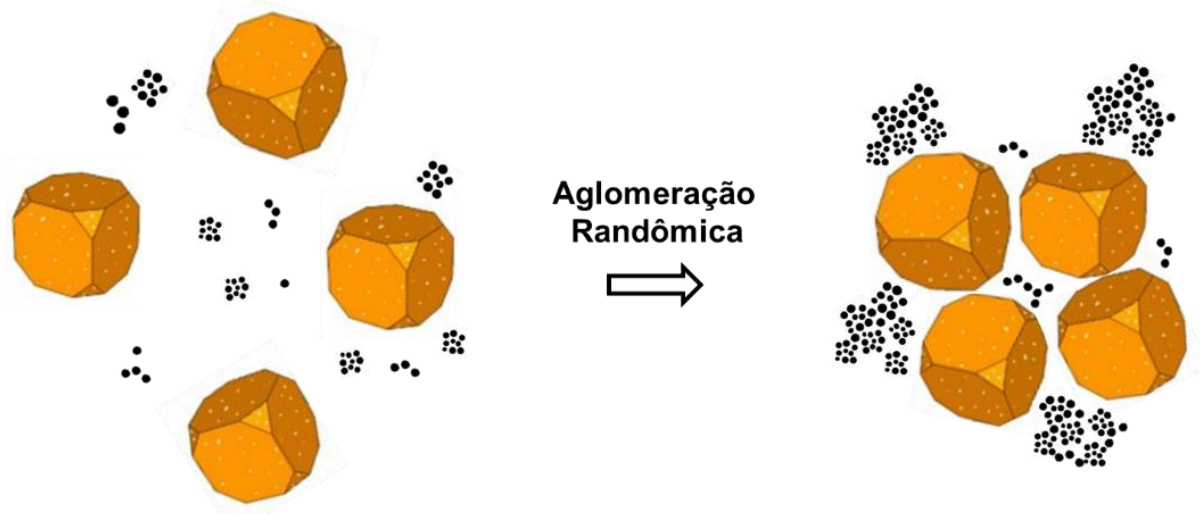

Fonte: Autoria própria.

Afim de avaliar o fenômeno de aglomeração randômica entre os nanocages bimetálicos e NPs- $\mathrm{Fe}_{3} \mathrm{O}_{4}$, os aglomerados formados por essas duas nanoestruturas foram depositados sobre um filme de carbono em uma grade de cobre de MET. Dessa forma, por meio das imagens de MET obtidas (Figura 36), comprovou-se a tendência das $\mathrm{NPs}^{-} \mathrm{Fe}_{3} \mathrm{O}_{4}$ de se posicionarem ao redor dos nanocages bimetálicos, levando a formação de grandes aglomerados. 
Figura 36- Imagens de MET dos aglomerados de nanocages bimetálicos de $\mathrm{Au} / \mathrm{Ag}$ e $\mathrm{NPs}-\mathrm{Fe}_{3} \mathrm{O}_{4}$ em filme de carbono.
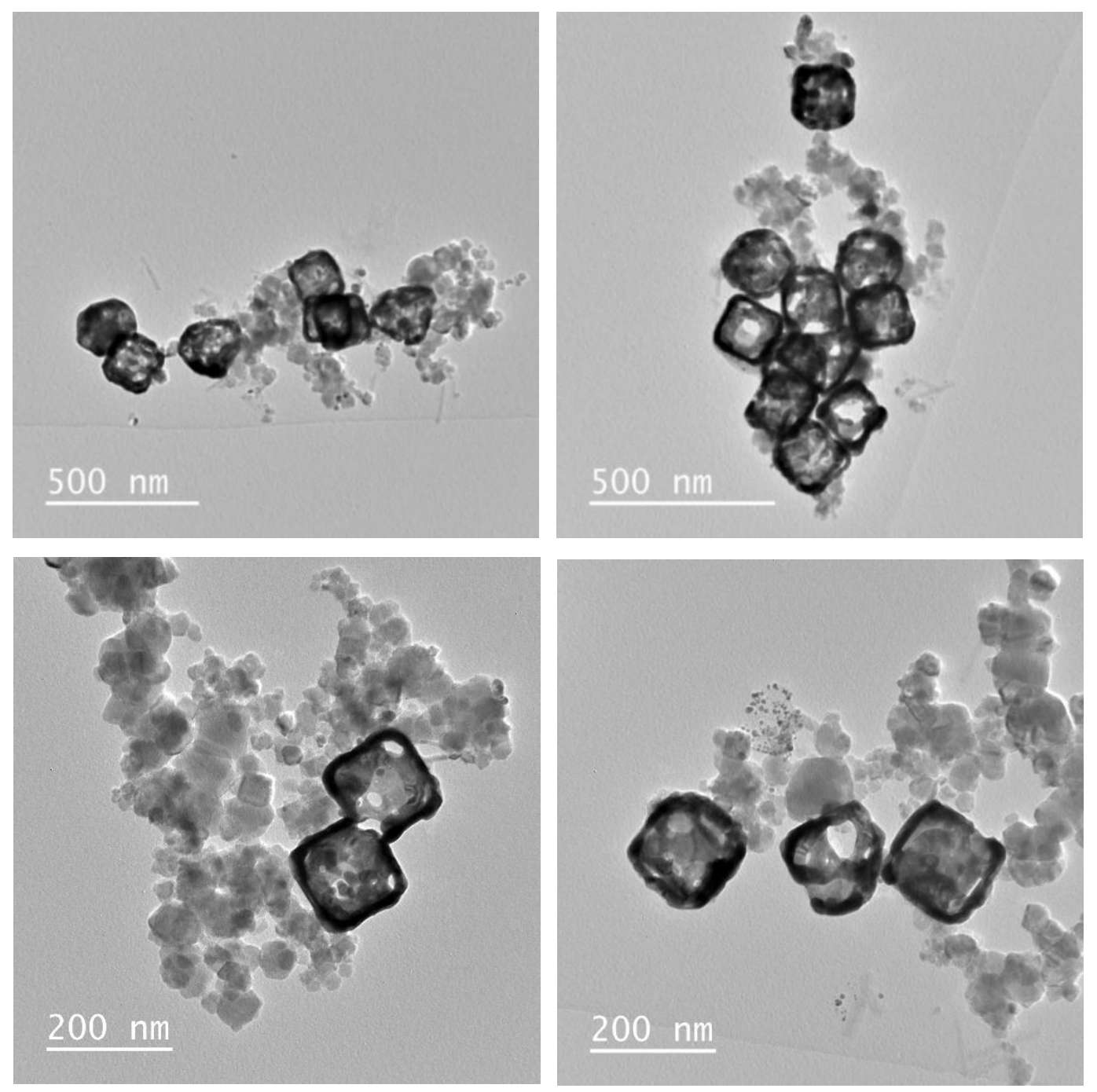

Após aglomeração e captura dos nanocages bimetálicos empregando $\mathrm{NPs}-\mathrm{Fe}_{3} \mathrm{O}_{4}$, avaliou-se por UV-Vis-NIR a transferência desses aglomerados do seio da suspensão até o local onde se encontra posicionada a máscara de cobre utilizada para a obtenção dos padrões litografia magnética. Para isso, como descrito no Tópico 3.4, empregou-se por 2 horas um campo magnético no valor de 0,2 T. A Figura 37 ilustra o monitoramento dos espectros de UV-Vis-NIR obtidos na presença (a) e na ausência (b) e de um campo magnético de valor constante. 
Figura 37- Espectros de UV-Vis-NIR para a suspensão contendo a mistura de nanocages bimetálicos e $\mathrm{NPs}-\mathrm{Fe}_{3} \mathrm{O}_{4}$. Esses espectros foram obtidos na presença (a) e na ausência (b) de um campo magnético constante $(B=0,2 \mathrm{~T})$. (c) Monitoramento dos valores de extinção da banda de SPR em $1075 \mathrm{~nm}$ observados em (a) e (b). Em destaque, as imagens (1) e (2) ilustram o comportamento da suspensão de interesse quando aplicado um campo magnético nos tempos 0 e $2 \mathrm{~h}$.

a)

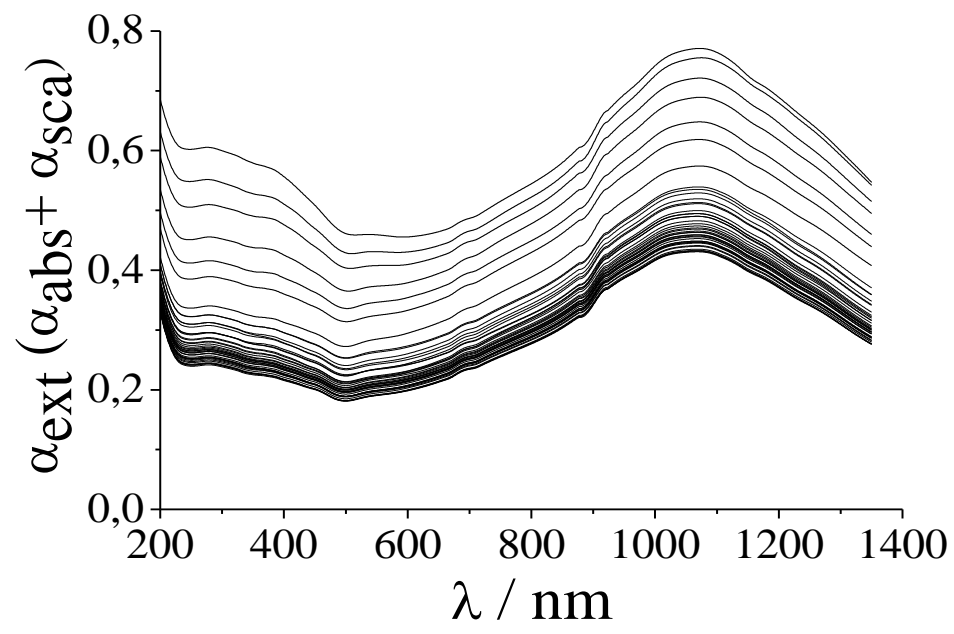

b)

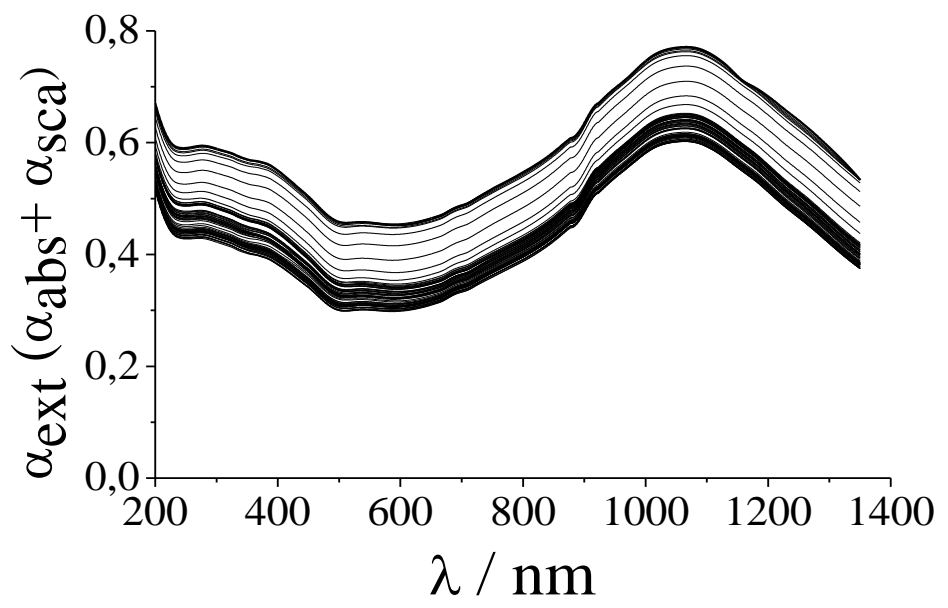

c)

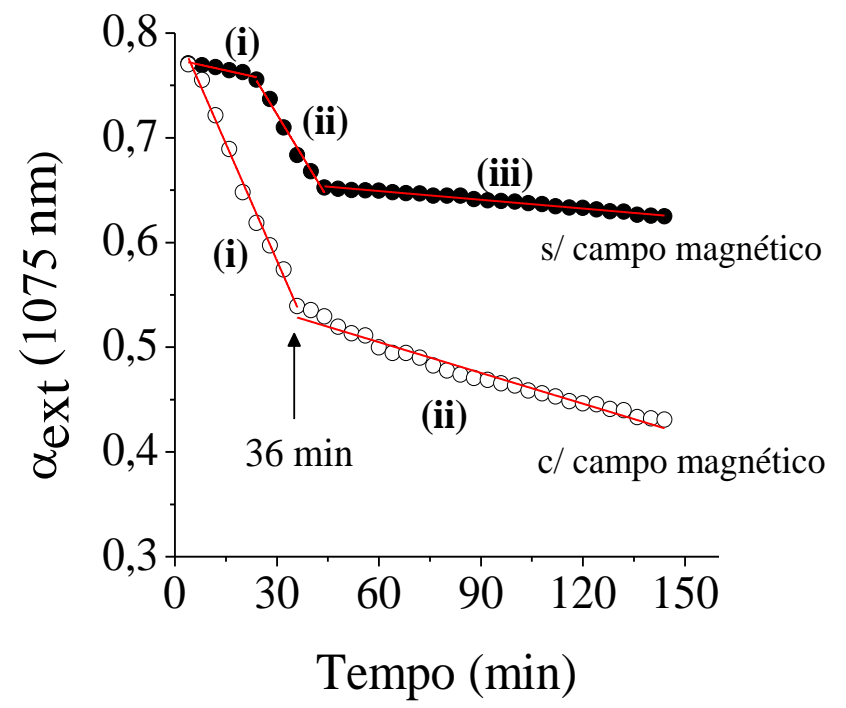

1)

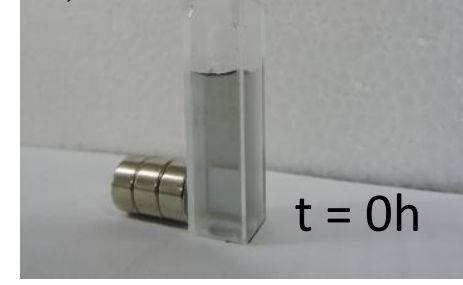

2) $t=2 h$ 
Na Figura 37, como ilustrado em (c), na presença de um campo magnético constante, observa-se um perfil com duas regiões bem características - regiões (i) e (ii). A região (i) corresponde à formação dos aglomerados de nanocages bimetálicos e $\mathrm{NPs}-\mathrm{Fe}_{3} \mathrm{O}_{4}$ em suspensão aquosa, e também, a transferência desses aglomerados por convecção forçada ${ }^{129}$ para o local onde se encontra posicionado a máscara litográfica. Após 36 minutos de aplicação do campo magnético, observa-se uma diminuição de 30,65 \% no valor de coeficiente de extinção $\left(\alpha_{\text {ext }}\right)$ relacionado à banda de SPR em 1075 nm. Já para a região (ii), tem-se um decaimento linear nos valores de extinção observados para esse mesmo comprimento de onda ( $\lambda=1075 \mathrm{~nm})$. Esse decaimento está relacionado à sedimentação dos nanocages remanescentes em suspensão aquosa - sedimentação ocasionada pela ação da gravidade. ${ }^{183}$ Por outro lado, na ausência do campo magnético constante, observa-se um perfil com três regiões distintas: regiões (i), (ii) e (iii). As regiões (i) e (ii) correspondem, respectivamente, à formação e sedimentação dos aglomerados de nanocages bimetálicos e $\mathrm{NPs}_{-} \mathrm{Fe}_{3} \mathrm{O}_{4}$ em suspensão aquosa, enquanto a região (iii) apresenta um decaimento linear nos valores de extinção observados em 1075 nm. Assim como na região (ii), ao ser aplicado um campo magnético constante, o perfil observado na região (iii) é característico da sedimentação dos nanocages remanescentes em suspensão.

A fim de demonstrar a reprodutibilidade na influência do campo magnético no processo de transferência dos nanocages bimetálicos aglomerados em $\mathrm{NPs}-\mathrm{Fe}_{3} \mathrm{O}_{4}$, reproduziu-se o experimento descrito no Tópico 3.4, no qual possibilitou a obtenção dos resultados apresentados na Figura 37. Para a realização desse novo experimento, primeiramente, descartaram-se os nanocages bimetálicos remanescentes após a decantação magnética dos aglomerados formados em suspensão, portanto, apenas os nanocages bimetálicos que interagiram previamente com as $\mathrm{NPs}_{-} \mathrm{Fe}_{3} \mathrm{O}_{4}$ foram utilizados. Além disso, é importante mencionar que, após a retirada do sobrenadante contendo os nanocages remanescentes, manteve-se o volume total da suspensão em $3 \mathrm{~mL}$, assim como na suspensão utilizada no experimento descrito no Tópico 3.4. Dessa forma, como ilustrado na Figura 38c, após o monitoramento da banda de SRP em 1075 nm por 2 horas, na ausência e na presença de um campo magnético constante, observa-se um comportamento similar quando comparado aos perfis ilustrados na Figura 37c. Isso demonstra a reprodutibilidade nas etapas de captura e transferência dos nanocages bimetálicos em suspensão aquosa afim de obter os padrões de litografia magnética. 


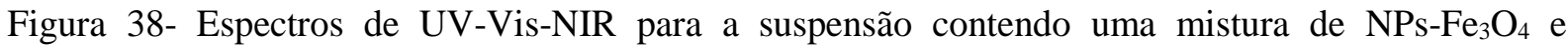
nanocages não remanescentes. Assim como na Figura 37, esses espectros foram obtidos na presença (a) e na ausência (b) de um campo magnético constante $(B=0,2 \mathrm{~T})$. (c) Monitoramento dos valores de extinção da banda de SPR em $1075 \mathrm{~nm}$ observados em (a) e (b).

a)

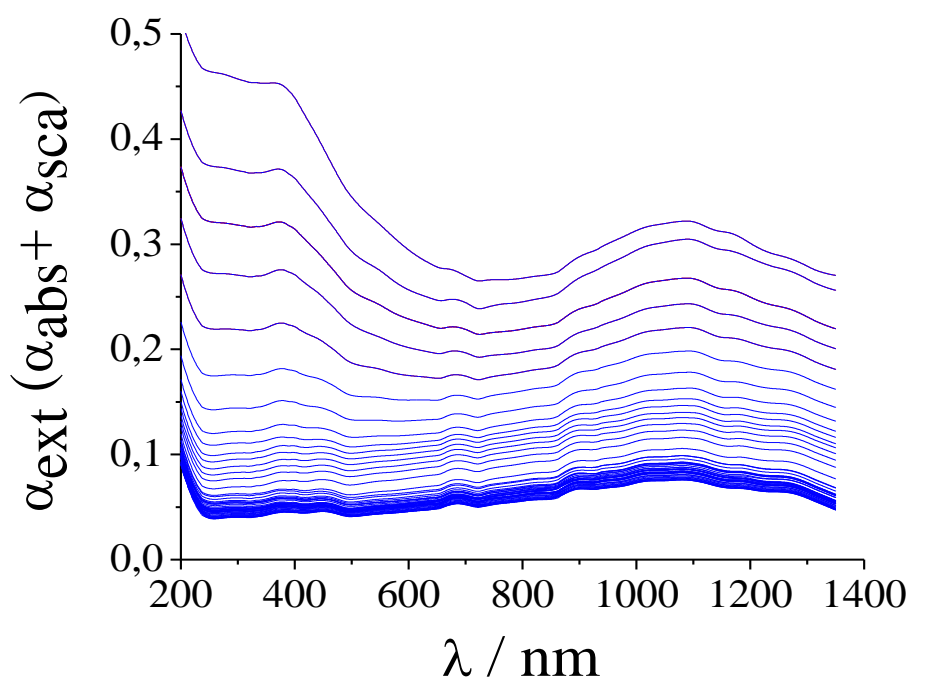

b)

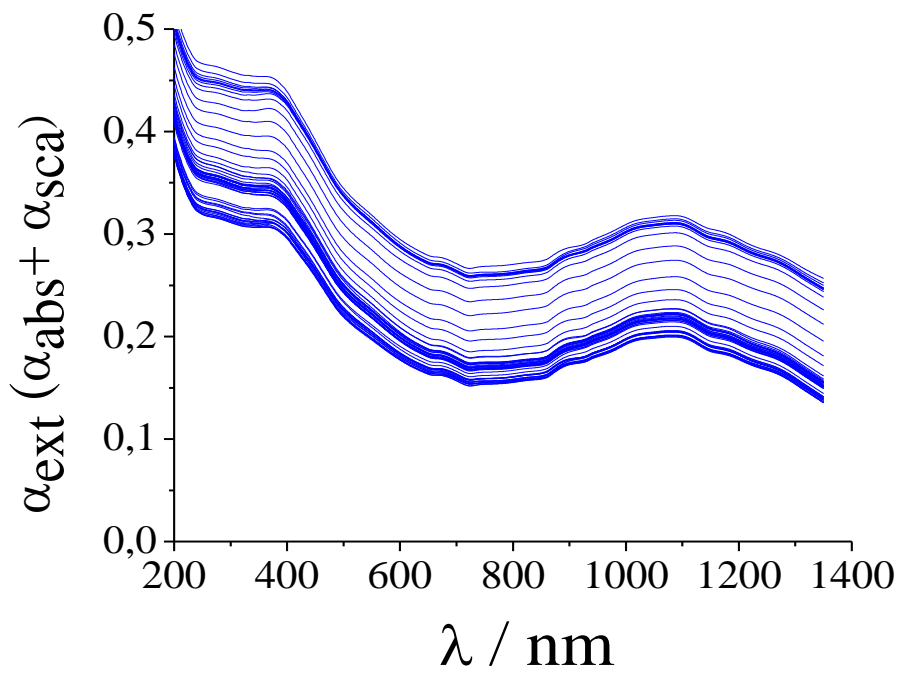

c)

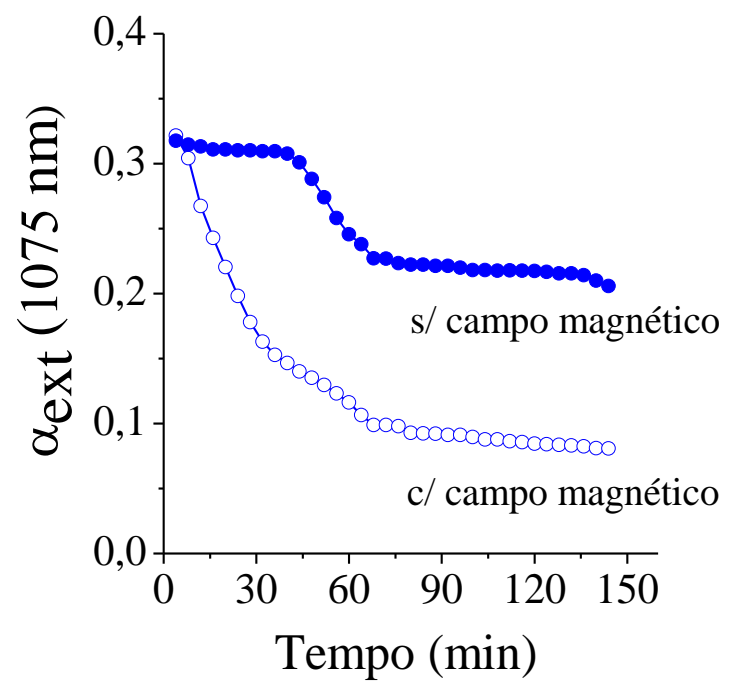




\subsection{Caracterização dos padrões de litografia magnética}

Imagens de MEV comprovaram que a metodologia utilizada para o preparo dos padrões de litografia magnética foi eficaz, apresentando um alto rendimento na obtenção dos mesmos. Para esse último, obteve-se uma média de 100 padrões dispostos homogeneamente em toda a superfície do substrato de ITO (Figuras 39a), no qual apresentou uma densidade por área de 162 padrões por milímetro quadrado. Além disso, analisando as imagens de MEV nas Figuras 39c e 39d, referentes às áreas em destaque nas Figuras 39a e 39b, respectivamente, nota-se uma significativa diferença quando comparado os perfis dos aglomerados de nanocages depositados em torno e sobre a malha que compõe a máscara litográfica. Nesse caso, essa diferença é dada pelo a uso da grade de cobre utilizada como máscara litográfica, na qual influência diretamente na disposição das linhas de campo magnético que atuam sobre a mesma. Portanto, os aglomerados depositados fora e sobre a malha que compõem a grade de cobre se alinham as linhas de campo de forma diferente.

Figura 39- Imagens de MEV dos padrões de litografia magnética sobre o substrato de ITO: as imagens observadas em (a) e (b) mostram a obtenção de padrões litográficos homogêneos com uma área aproximada de $3600 \mu \mathrm{m}^{2}$, enquanto as imagens em (c) e (d), referentes às áreas em destaque observadas em (a) e (b), respectivamente, mostram a diferença no perfil dos aglomerados de nanocages bimetálicos após deposição fora e sobre a malha que compõe a grade cobre utilizada como máscara litográfica.

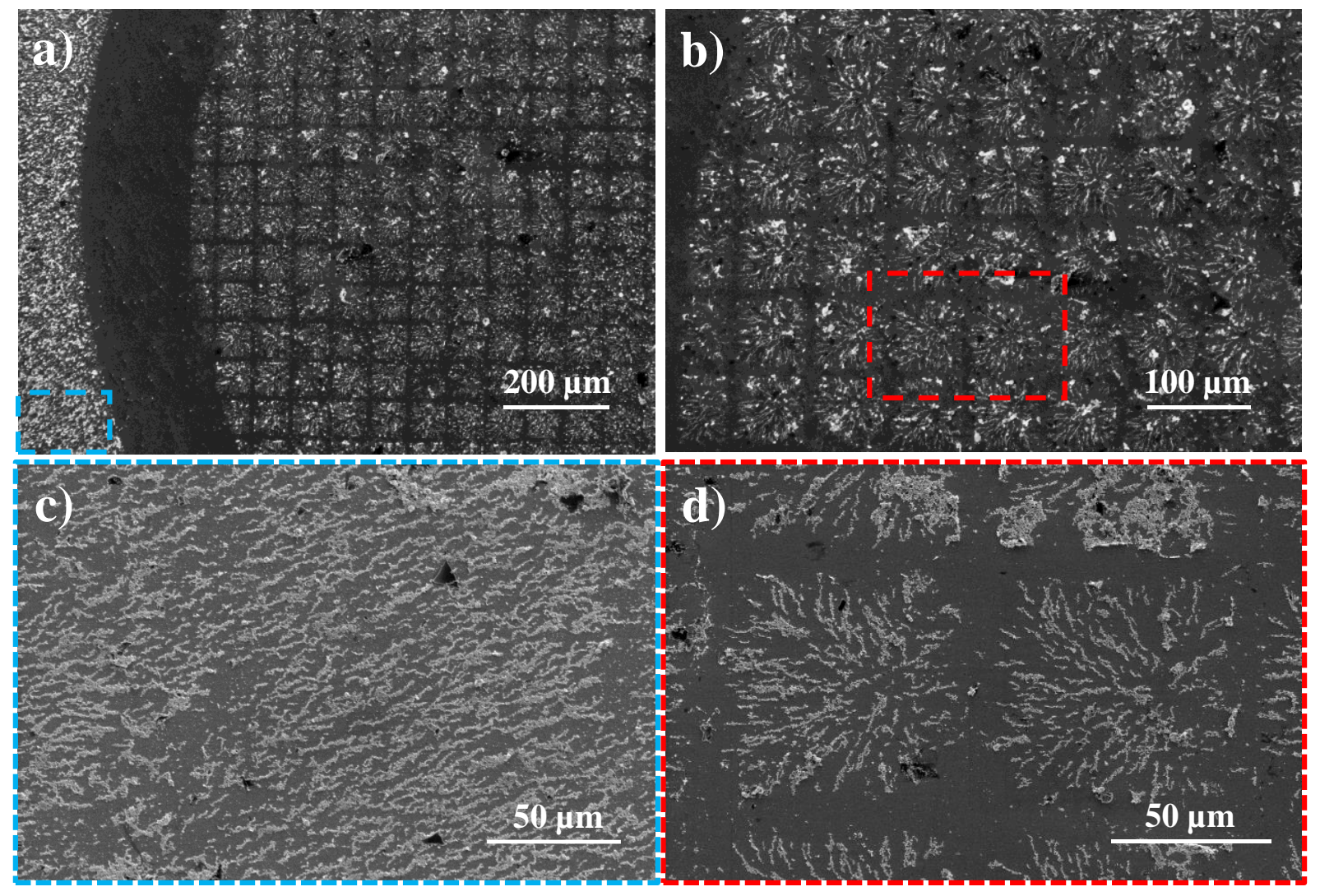


Por meio de imagens de MEV-FEG, nota-se que os aglomerados de nanocages bimetálicos e $\mathrm{NPs}_{-} \mathrm{Fe}_{3} \mathrm{O}_{4}$ depositados sobre a malha que compõe a máscara de cobre, encontram-se alinhados na forma de microfios (Figura 40a-d). Além disso, como ilustrado na Figuras 41a e 41b, observa-se a reorganização desses aglomerados após serem depositados sobre a superfície do substrato de ITO, nas quais as $\mathrm{NPs}-\mathrm{Fe}_{3} \mathrm{O}_{4}$ (indicadas pelas setas amarelas) apresentaram uma tendência de se posicionarem na interface criada entre a superfície do ITO e os nanocages bimetálicos. Para melhor entendimento a respeito dessa reorganização, veja a ilustração apresentada na Figura 41c.

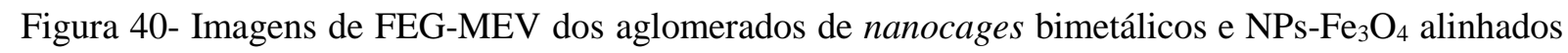
na forma de microfios sobre a superfície do substrato de ITO (a, b, c e d).
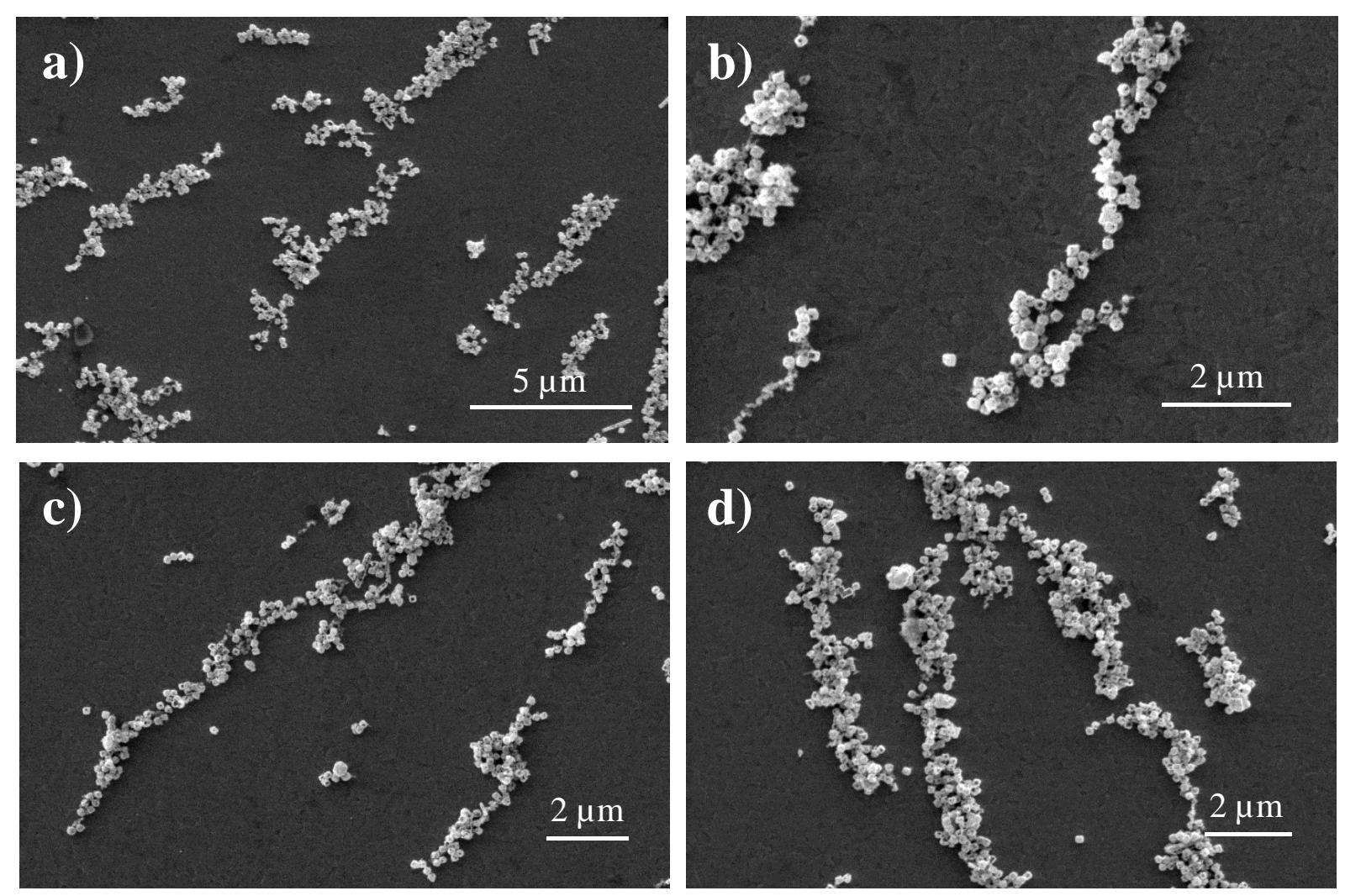
Figura 41- Imagens de FEG-MEV em (a) e (b) dos aglomerados mostrados na Figura 40d, evidenciando a tendência das NPs- $\mathrm{Fe}_{3} \mathrm{O}_{4}$ (indicadas pelas setas amarelas) de se posicionarem na interface criada entre a superfície do ITO e os nanocages bimetálicos. (c) Ilustração esquemática da transferência, deposição e reorganização dos aglomerados de nanocages bimetálicos e $\mathrm{NPs}-\mathrm{Fe}_{3} \mathrm{O}_{4}$ sobre na superfície do substrato de ITO após aplicação de um campo magnético de valor constante.
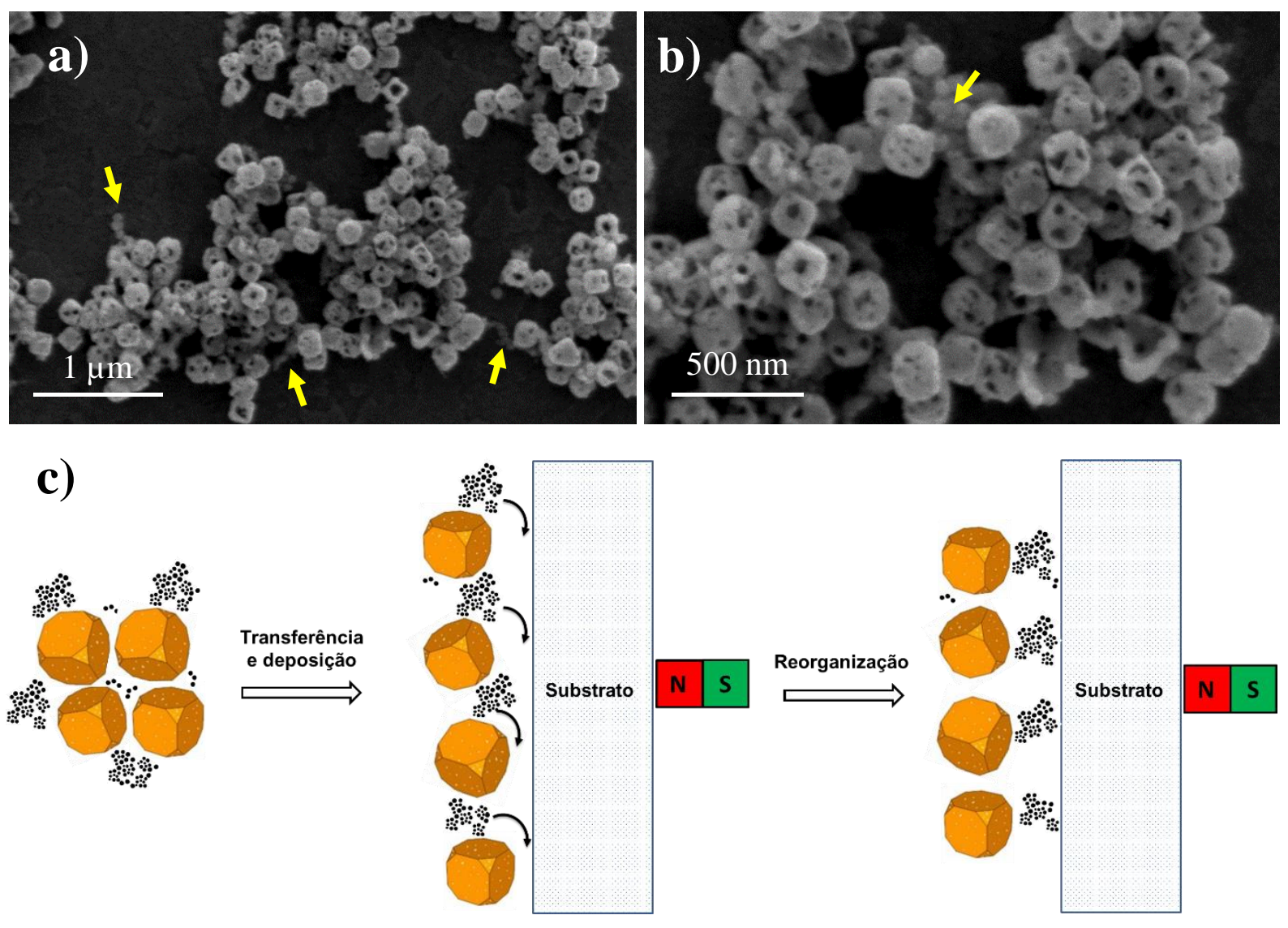

De acordo com alguns trabalhos reportados na literatura, acredita-se que os padrões de litografia magnética arranjados em macroescala, juntamente com os aglomerados de nanocages alinhados na forma de microfios, possuem potencial aplicação em estudos de espectroscopia de absorção no infravermelho intensificado por superfície (SEIRA) ${ }^{164}$ Em estudos dessa natureza, esses microfios podem ser utilizados como antenas ópticas ${ }^{163,165}$ para intensificação dos modos vibracionais de moléculas orgânicas depositadas sobre os mesmos na forma de filmes finos. Para isso, quando um feixe de radiação eletromagnética na região do infravermelho é incidido sobre os aglomerados de nanocages bimetálicos de Au/Ag, tem-se a presença de hot-spots que apresentam um campo elétrico de grande intensidade próximo as interfaces criadas entre dois ou mais nanocages, favorecendo a intensificação dos modos vibracionais das moléculas orgânicas. ${ }^{184}$ 


\subsection{Modificação dos nanocages bimetálicos e mapeamento químico de infravermelho dos padrões de litografia magnética}

Durante a reação de substituição galvânica para obtenção dos nanocages bimetálicos de $\mathrm{Au} / \mathrm{Ag}$, utilizaram-se moléculas do polímero PVP para modificar a sua superfície a fim proporcionar um maior tempo de estabilização coloidal em suspensão aquosa. ${ }^{172}$ Por FTIR, em modo transmitância, confirmou-se a interação das moléculas de PVP com a superfície dos nanocages bimetálicos de Au/Ag. Na Figura 42, têm-se os espectros de FTIR para as amostras de PVP (linha verde) e nanocages bimetálicos (linha azul). Para o espectro do PVP, as bandas em 1661 e 1291 cm$^{-1}$ são atribuídas aos modos vibracionais $\mathrm{C}=\mathrm{O}$ e $\mathrm{C}-\mathrm{N}$, respectivamente, enquanto as bandas em 1463 e $1424 \mathrm{~cm}^{-1}$ são referentes às deformações angulares $-\mathrm{CH}_{2}$ presentes no anel pirrolidinil. Além disso, observa-se uma banda de baixa intensidade em $2955 \mathrm{~cm}^{-1}$ referente às vibrações de estiramento assimétrico $\left(v^{\mathrm{as}}\right) \mathrm{C}-\mathrm{H}$. Por outro lado, para o espectro de FTIR dos nanocages bimetálicos de Au/Ag, nota-se a existência dos principais modos vibracionais observados anteriormente no espectro do PVP, comprovando a presença desse polímero na superfície metálica dessas nanoestruturas metálicas hollow. Entretanto, nesse espectro, alguns modos vibracionais apresentam uma menor intensidade e um deslocamento para menores números de onda. Como exemplo, têm-se os modos vibracionais $\mathrm{C}=\mathrm{O}$ e $\mathrm{C}-\mathrm{N}$, sendo observados em 1645 e $1261 \mathrm{~cm}^{-1}$, respectivamente.

Figura 42- Espectros de FTIR referentes às amostras de PVP (linha verde) e dos nanocages bimetálicos de $\mathrm{Au} / \mathrm{Ag}$ (linha azul). Em destaque, tem-se a representação da estrutura química da unidade de repetição do polímero PVP.

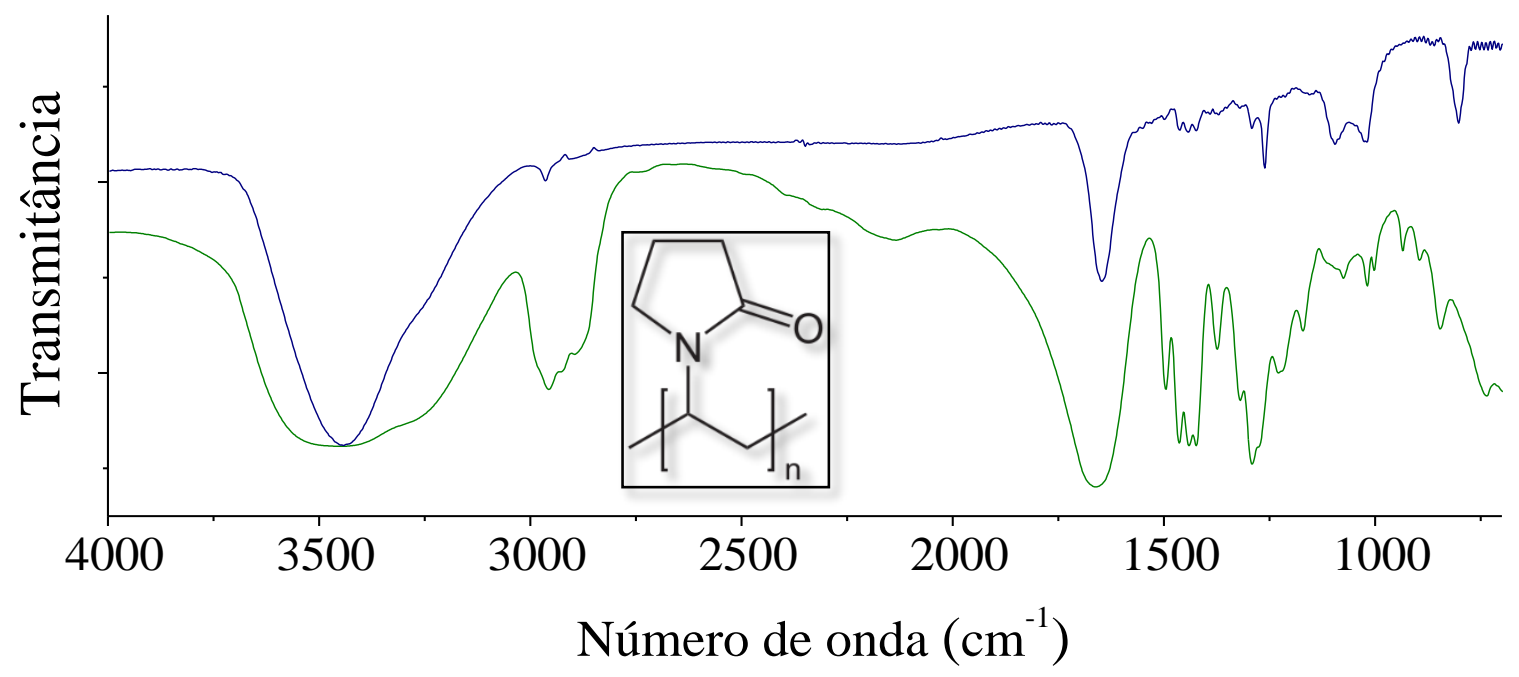


A Tabela 4 apresenta as atribuições das principais bandas observadas para os dois espectros de FTIR ilustrado na Figura 42.

Tabela 4- Atribuição das bandas observadas nos espectros de FTIR referentes às amostras de PVP e dos nanocages bimetálicos com superfície modificada.

\begin{tabular}{ccc}
\hline \multicolumn{2}{c}{ Bandas $\left(\mathbf{c m}^{-1}\right)$} & Atribuição \\
\cline { 1 - 2 } PVP & nanocages modificados & \\
\hline 2955 & & $v^{\text {as }} \mathrm{C}-\mathrm{H}$ \\
1661 & $\mathrm{C}=\mathrm{O}$ \\
1291 & 1645 & $\mathrm{C}-\mathrm{N}$ \\
1463 & 1261 & $\delta$ angular $-\mathrm{CH}_{2}$ \\
1424 & & $\delta$ angular $-\mathrm{CH}_{2}$ \\
\hline$(v=$ estiramento, $\delta=$ deformação)
\end{tabular}

$\mathrm{Na}$ literatura, estudos envolvendo modelagens computacionais do tipo DFT e MD, ${ }^{166}$ aliados a tratamentos empíricos, ${ }^{186,187}$ sugerem que a interação do monômero do PVP sobre os planos (111) do ouro é termodinamicamente mais favorável quando comparada aos planos (100). Portanto, a interação desse polímero ocorre preferencialmente nos cantos dos nanocages bimetálicos, onde são observadas curvaturas negativas após o processo de dealloying (veja a representação esquemática na Figura 43). Para esse último, a espessura da camada polimérica de PVP na forma oligomérica é de aproximadamente $2 \mathrm{~nm},{ }^{188}$ além disso, a interação das moléculas de PVP e a superfície dos nanocages bimetálicos acontece por meio dos átomos de oxigênios presentes no grupo carbonila. ${ }^{185}$ Em destaque na Figura 42, tem-se a representação da estrutura química da unidade de repetição do polímero PVP.

Figura 43- Representação esquemática da interação de PVP, na forma oligomérica, sobre os planos (111) dos nanocages bimetálicos de Au/Ag.

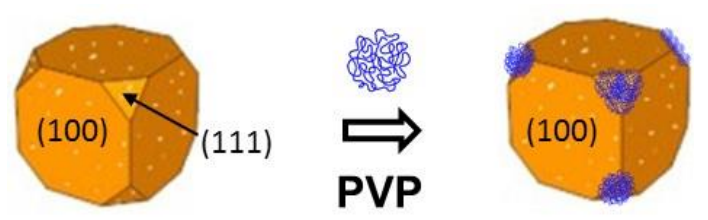


O mapeamento químico de infravermelho (em modo de reflectância difusa) dos padrões de litografia magnética foi realizado em conjunto com a técnica de microscopia óptica (Figura 44). Para a obtenção desse mapeamento, realizaram-se as etapas descritas abaixo:

Etapa 1: Primeiramente, espectros de absorção foram coletados em pontos distribuídos uniformemente sobre uma área de $98.117 \mu \mathrm{m}^{2}$ após a incidência de feixes de radiação eletromagnética, na região do infravermelho, de forma normal à superfície do ITO. Para essa área analisada contendo 16 padrões litográficos, obteve-se uma coleta de aproximadamente 21.947 pontos, com uma resolução de pixel de 2,7 $\mu \mathrm{m}$. Além disso, para cada ponto coletado, obtiveram-se 32 espectros de absorção empregando uma janela de 4000 a $900 \mathrm{~cm}^{-1}$, com resolução de $8 \mathrm{~cm}^{-1}$. Por fim, os valores de absorção correspondentes aos espectros obtidos foram automaticamente subtraídos do branco.

Etapa 2: Após a coleta dos espectros de absorção sobre a superfície do ITO, onde estão distribuídos os padrões de litografia magnética, selecionou-se a região espectral ilustrada na Figura 44b, na qual apresenta bandas de absorção observadas no intervalo de 1780 a $1250 \mathrm{~cm}^{-1}$. Dessa forma, por meio da integração da área selecionada, foi possível observar a distribuição da molécula alvo presente nos padrões litográficos, como ilustrado no mapa químico na Figura 44a. Para esse experimento, o alvo analisado foram os modos vibracionais oriundos das moléculas de PVP que estão presentes na superfície dos nanocages bimetálicos de Au/Ag.

Figura 44- (a) Mapeamento químico dos padrões de litografia magnética em substrato de ITO. (b) Espectros de absorção (em modo reflectância difusa) coletados dentro (linha vermelha) e fora (linha preta) dos padrões litográficos, onde as suas posições estão indicadas no mapa químico em 1 e 2 , respectivamente. Para a construção do mapa químico observado em (a), integrou-se à área em destaque em (b) que compreende os modos vibracionais das moléculas de PVP presentes na superfície dos nanocages bimetálicos de $\mathrm{Au} / \mathrm{Ag}$.
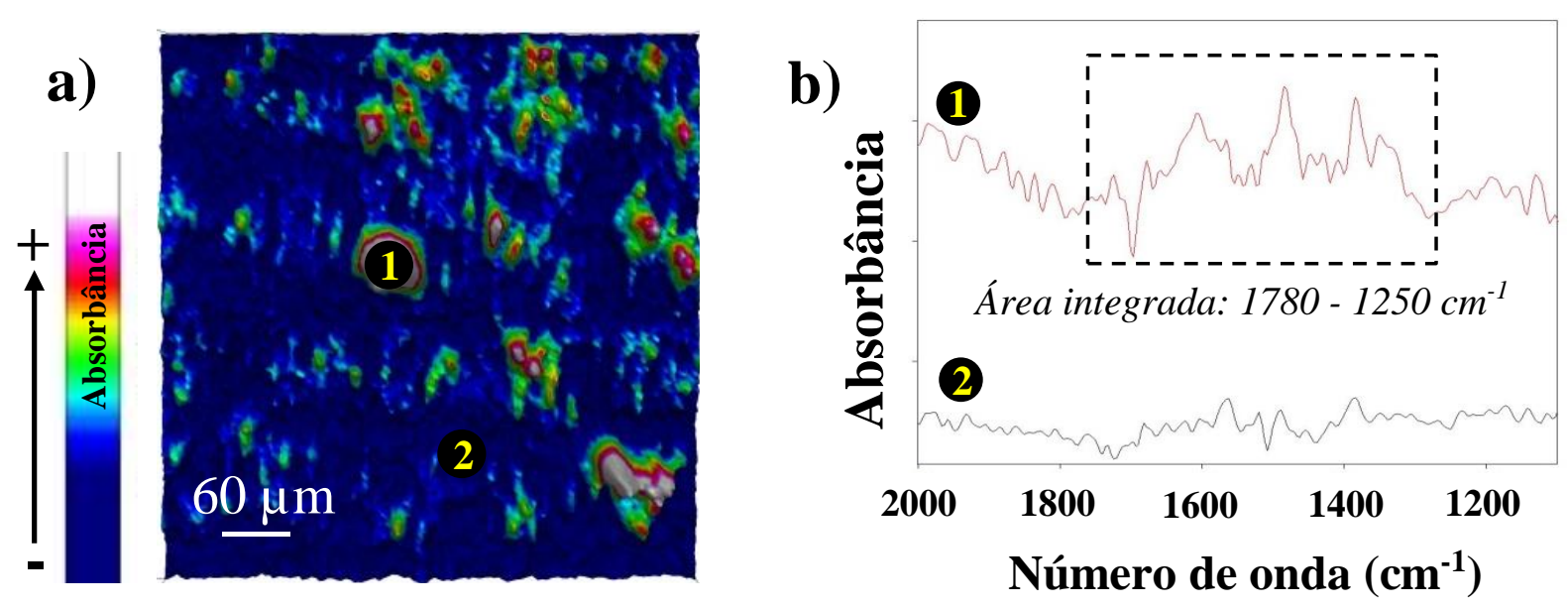
A Figura 44b ilustra os espectros de absorção coletados dentro (linha vermelha) e fora (linha preta) dos padrões litográficos, onde as suas posições estão indicadas no mapa químico em 1 e 2, respectivamente. Analisando a região em destaque apresentada no espectro em vermelho, nota-se claramente a presença das principais bandas de absorção observadas previamente no espectro dos nanocages bimetáicos modificados com PVP (Figura 42). Portanto, os modos vibracionais $\mathrm{C}=\mathrm{O}, \mathrm{C}-\mathrm{N}$ e $-\mathrm{CH}_{2}$, compreendidos no intervalo de 1780 a $1250 \mathrm{~cm}^{-1}$, foram utilizados para o mapeamento químico dos padrões de litografia magnética sobre o substrato de ITO.

Esses resultados sugerem que a técnica de mapeamento químico de infravermelho pode ser empregada como uma poderosa ferramenta para identificar determinadas reações que venham acontecer especificamente sobre a superfície de cada padrão de litografia magnética. 


\section{Conclusão}

Padrões de litografia magnética distribuídos sobre a superfície de um substrato de ITO

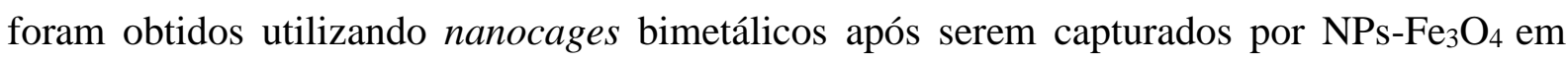
suspensão aquosa. Esse comportamento apresentado pelos aglomerados de $\mathrm{NPs}-\mathrm{Fe}_{3} \mathrm{O}_{4}$ durante a captura das nanoestruturas metálicas hollow em suspensão aquosa foi denominado de adesivo

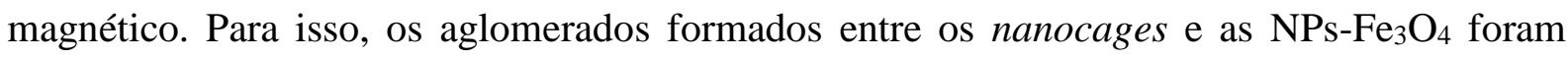
retirados do seio de uma suspensão por ação de um campo magnético constante e, em seguida, depositados sobre uma máscara litográfica de cobre. Após 36 minutos da aplicação do campo magnético, observou-se uma diminuição de $30,65 \%$ no valor do coeficiente de extinção $\left(\alpha_{\text {ext }}\right)$ relacionado à banda de SPR dos nanocages bimetálicos em $1075 \mathrm{~nm}$.

Imagens de MEV comprovaram que a metodologia utilizada para o preparo dos padrões de litografia magnética foi eficaz, apresentando um alto rendimento na obtenção dos mesmos. Para esse último, obteve-se uma média de 100 padrões litográficos dispostos em toda a superfície do substrato de ITO, no qual apresentou uma densidade por área de 162 padrões por milímetro quadrado. Por meio de imagens de MEV-FEG, comprovou-se a reorganização dos aglomerados na superfície do substrato de ITO, nas quais as $\mathrm{NPs}_{-}-\mathrm{Fe}_{3} \mathrm{O}_{4}$ apresentam uma tendência de se posicionarem na interface criada entre os nanocages bimetálicos e a superfície do substrato de ITO. Ademais, analisando as imagens de MEV-FEG, nota-se que, os aglomerados depositados sobre a superfície do ITO, encontram-se alinhados na forma de microfios, devido à ação das linhas de campo atuando sobre a máscara litográfica. De acordo com trabalhos reportados na literatura, acredita-se que os padrões litografia magnética arranjados em macroescala, juntamente com os aglomerados de nanocages alinhados na forma de microfios, possuem potencial aplicação em estudos de SEIRA. Para esse tipo de estudo, esses microfios podem ser utilizados como antenas ópticas a fim de intensificar os modos vibracionais de moléculas orgânicas depositadas sobre os mesmos na forma de filmes finos.

Durante a reação de substituição galvânica empregada no processo de obtenção dos nanocages bimetálicos, utilizaram-se moléculas do polímero PVP para modificar a superfície dessas nanoestruturas metálicas hollow, levando a um maior tempo de estabilização coloidal em suspensão aquosa. Por FTIR, em modo transmitância, confirmou-se a interação das moléculas de PVP com a superfície dos nanocages bimetálicos de Au/Ag. Para esse último, a interação de PVP com a superfície metálica dos nanocages acontece por meio dos átomos de oxigênios presentes no grupo carbonila. 
O mapeamento químico de infravermelho (em modo de reflectância difusa) dos padrões de litografia magnética foi realizado em conjunto com a técnica de microscopia óptica. Para esse experimento, o alvo analisado foram os modos vibracionais do PVP presente na superfície dos nanocages bimetálicos de Au/Ag. De acordo com as bandas de absorção compreendidas no intervalo de 1780 a $1250 \mathrm{~cm}^{-1}$, apenas os modos vibracionais $\mathrm{C}=\mathrm{O}, \mathrm{C}-\mathrm{N}$ e $-\mathrm{CH}_{2}$ do $\mathrm{PVP}$ foram responsáveis para a construção do mapeamento químico de infravermelho dos padrões de litografia magnética dispostos sobre o substrato de ITO. Esses resultados sugerem que a técnica de mapeamento químico de infravermelho pode ser empregada como uma poderosa ferramenta para identificar determinadas reações que venham acontecer especificamente sobre a superfície de cada padrão de litográfico contendo aglomerados de nanocages bimetálicos e $\mathrm{NPs}_{-} \mathrm{Fe}_{3} \mathrm{O}_{4}$. 


\section{Referências}

1 MARTINS, M. V. A.; PEREIRA, A. R.; LUZ, R. A. S.; IOST, R. M.; CRESPILHO, F. N. Evidence of short-range electron transfer of a redox enzyme on graphene oxide electrodes. Physical Chemistry Chemical Physics, v. 16, n. 33, p.17426-17436, 2014.

2 YEH, P.; KUWANA, T. Reversible electrode reaction of cytochrome c. Chemistry Letters, n. 10, p. 1145-1148, 1977.

3 EDDOWES, M. J.; HILL, H. A. O. Novel method for the investigation of the electrochemistry of metalloproteins: cytochrome c. Journal of the Chemical Society, Chemical Communications, n. 21, p. 771b-772, 1977.

4 REED, D. E.; HAWKRIDGE, F. M. Direct electron transfer reactions of cytochrome c at silver electrodes. Analytical Chemistry, v. 59, n. 19, p. 2334-2339, 1987.

5 HAGEN, W. R. Direct electron transfer of redox proteins at the bare glassy carbon electrode. European Journal of Biochemistry, v. 182, n. 3, p. 523-530, 1989.

6 SUN, S. C.; REED, D. E.; CULLISON, J. K.; RICKARD, L. H.; HAWKRIDGE, F. M. Electron transfer reactions of cytochrome c at metal electrodes. Microchimica Acta, v. 96, n. 1-6, p. 97-104, 1988.

7 WILLNER, I.; LION-DAGAN, M.; MARX-TIBBON, S.; KATZ, E. Bioelectrocatalyzed amperometric transduction of recorded optical signals using monolayer-modified Auelectrodes1. Journal of the American Chemical Society, v.117, n. 24, p. 6581-6592, 1995.

8 BOCHAROVA, V.; KATZ, E. Switchable electrode interfaces controlled by physical, chemical and biological signals. The Chemical Record, v. 12, n. 1, p. 114-130, 2012.

9 KATZ, E.; MINKO, S.; HALÁMEK, J.; MACVITTIE, K.; YANCEY, K. Electrode interfaces switchable by physical and chemical signals for biosensing, biofuel, and biocomputing applications. Analytical and Bioanalytical Chemistry, v. 405, n. 11, 3659$3672,2013$.

10 KATZ, E. Magneto-switchable electrodes and electrochemical systems. Electroanalysis, v. 28, p. $904-919,2015$.

11 WANG, J.; KAWDE, A. N. Magnetic-field stimulated DNA oxidation. Electrochemistry Communications, v. 4, n. 4, p. 349-352, 2002. 
12 KATZ, E.; WILLNER, I. Magnetic control of chemical transformations: application for programmed electrocatalysis and surface patterning. Electrochemistry Communications, v. 4, n. 2, p. 201-204, 2002.

13 KATZ, E.; LÖTZBEYER, T.; SCHLERETH, D. D.; SCHUHMANN, W.; SCHMIDT, H. L. Electrocatalytic oxidation of reduced nicotinamide coenzymes at gold and platinum electrode surfaces modified with a monolayer of pyrroloquinoline quinone. Effect of Ca2+ cations. Journal of Electroanalytical Chemistry, v. 373, n .1-2, p. 189-200, 1994.

14 KATZ, E.; BARON, R.; WILLNER, I. Magnetoswitchable electrochemistry gated by alkyl-chain-functionalized magnetic nanoparticles: Control of diffusional and surfaceconfined electrochemical processes. Journal of the American Chemical Society, v. 127, n. 11, p. 4060-4070, 2005.

15 MELO, A. F. A. A.; LUZ, R. A. S.; IOST, R. M., NANTES, I. L.; CRESPILHO, F. N. Highly stable magnetite modified with chitosan, ferrocene and enzyme for application in magneto-switchable bioelectrocatalysis. Journal of the Brazilian Chemical Society, v. 24, n. 2, p. 285-294, 2013.

16 MELO, A. F. A. A., CARVAlHO, V. A. N., PAGNONCELli, K. C., CRESPILHO, F. N. Single microparticle applied in magnetic-switchable electrochemistry. Electrochemistry Communications, v. 30, p. 79-82, 2013.

17 MATHEWS, F. S. The structure, function and evolution of cytochromes. Progress in Biophysics and Molecular Biology, v. 45, n. 1, p. 1-56, 1985.

18 SALEMME, F. R. Structure and function of cytochromes c. Annual Review of Biochemistry, v. 46, n. 1, p. 299-330, 1977.

19 VOET, D.; VOET, J. G.; PRATT, C. W. Fundamentos de bioquímica: a vida em nível molecular. 4 ed. Porto Alegre: Artmed, 2014. 1200 p.

20 GREEN, D. R.; REED, J. C. Mitochondria and apoptosis. Science, v. 281, n. 5381, p. 1309-1312, 1998.

21 PELLETIER, H.; KRAUT, J. Crystal structure of a complex between electron transfer partners, cytochrome c peroxidase and cytochrome c. Science, v. 258, n. 5089, p. 1748-1755, 1992. 
22 SIVAKOLUNDU, S. G.; MABROUK, P. A. Cytochrome c structure and redox function in mixed solvents are determined by the dielectric constant. Journal of the American Chemical Society, v. 122, n. 7, p. 1513-1521, 2000.

23 ZHAO, G. C.; YIN, Z. Z.; ZHANG, L.; WEI, X. W. Direct electrochemistry of cytochrome $\mathrm{c}$ on a multi-walled carbon nanotubes modified electrode and its electrocatalytic activity for the reduction of $\mathrm{H}_{2} \mathrm{O}_{2}$. Electrochemistry Communications, v. 7, n. 3, p. 256$260,2005$.

24 NAKASHIMA, T.; HIGA, H.; MATSUBARA, H.; BENSON, A. M.; YASUNOBU, K. T. The amino acid sequence of bovine heart cytochrome c. Journal of Biological Chemistry, $v$. 241, n. 5, p. 1166-1177, 1966.

25 DICKERSON, R. E.; TAKANO, T.; EISENBERG, D.; KALLAI, O. B.; SAMSON, L.; COOPER, A.; MARGOLIASH, E. Ferricytochrome c I. General features of the horse and bonito proteins at 2.8 A resolution. Journal of Biological Chemistry, v. 246, n. 5, p. 1511$1535,1971$.

26 WÜTHRICH, K.; AVIRAM, I.; SCHEJTER, A. Structural studies of modified cytochromes c by nuclear magnetic resonance spectroscopy. Biochimica et Biophysica Acta (BBA) Bioenergetics, v. 253, n. 1, p. 98-103, 1971.

27 SUTIN, N.; YANDELL, J. K. Mechanisms of the reactions of cytochrome c. Journal of Biological Chemistry, v. 247, n. 21, p. 6932-6936, 1972.

28 COMPTON, D. L.; LASZLO, J. A. Loss of cytochrome c Fe (III)/Fe (II) redox couple in ionic liquids. Journal of Electroanalytical Chemistry, v. 553, p. 187-190, 2003.

29 MARCUS, R. A.; SUTIN, N. Electron transfers in chemistry and biology. Biochimica et Biophysica Acta (BBA)-Reviews on Bioenergetics, v. 811, n. 3, p. 265-322, 1985.

30 MARCUS, R. A. Electron transfer reactions in chemistry: theory and experiment (Nobel lecture). Angewandte Chemie International Edition in English, v. 32, n. 8, p. 1111-1121, 1993.

31 LUZ, R. A.; CRESPILHO, F. N. Gold nanoparticle-mediated electron transfer of cytochrome c on a self-assembled surface. RSC Advances, v. 6, n. 67, p. 62585-62593, 2016.

32 CHIDSEY, C. E. Free energy and temperature dependence of electron transfer at the metal-electrolyte interface. Science, v. 251, n. 4996, p. 919-922, 1991 
33 SASSOLAS, A.; BLUM, L. J.; LECA-BOUVIER, B. D. Immobilization strategies to develop enzymatic biosensors. Biotechnology Advances, v. 30, n. 3, p. 489-511, 2012.

34 KRAJEWSKA, B. Ureases. II. Properties and their customizing by enzyme immobilizations: A review. Journal of Molecular Catalysis B: Enzymatic, v. 59, n. 1, p. 22-40, 2009.

35 KRAJEWSKA, B. Application of chitin-and chitosan-based materials for enzyme immobilizations: a review. Enzyme and Microbial Technology, v. 35, n. 2, p. 126-139, 2004.

36 FERNÁNDEZ-FERNÁNDEZ, M.; SANROMÁN, M. Á.; MOLDES, D. Recent developments and applications of immobilized laccase. Biotechnology Advances, v. 31, n. 8, p. 1808-1825, 2013.

37 JANEGITZ, B. C.; FIGUEIREDO-FILHO, L. C. S.; MARCOLINO-JUNIOR, L. H.; SOUZA, S. P.; PEREIRA-FILHO, E. R.; FATIBELLO-FILHO, O. Development of a carbon nanotubes paste electrode modified with crosslinked chitosan for cadmium (II) and mercury (II) determination. Journal of Electroanalytical Chemistry, v. 660, n. 1, 209-216, 2011.

38 ANSARI, S. A.; HUSAIN, Q. Potential applications of enzymes immobilized on/in nano materials: A review. Biotechnology Advances, v. 30, n. 3, p. 512-523, 2012.

39 DORIA, G.; CONDE, J.; VEIGAS, B.; GIESTAS, L.; ALMEIDA, C.; ASSUNÇÃO, M.; ROSA, J.; BAPTISTA, P. V. Noble metal nanoparticles for biosensing applications. Sensors, v. 12, n. 2, p. 1657-1687, 2012.

40 CAO, G. Nanostructures \& nanomaterials: synthesis properties and applications. London: Imperial College, 2004. 433 p.

41 CULLITY, B. D.; GRAHAM, C. D. Introduction to magnetic materials. 2. ed. New York: John Wiley, 2009. 544 p.

42 SUN, C.; LEE, J. S.; ZHANG, M. Magnetic nanoparticles in MR imaging and drug delivery. Advanced Drug Delivery Reviews, v. 60, n. 11, p. 1252-1265, 2008.

43 LI, Z.; WEI, L.; GAO, M. Y.; LEI, H. One-pot reaction to synthesize biocompatible magnetite nanoparticles. Advanced Materials, v. 17, n. 8, p. 1001-1005, 2005. 
44 SUN, X. H.; ZHENG, C. M.; ZHANG, F. X.; YANG, Y. L.; WU, G. J.; YU, A. M.; GUAN, N. J. Size-controlled synthesis of magnetite $\left(\mathrm{Fe}_{3} \mathrm{O}_{4}\right)$ nanoparticles coated with glucose and gluconic acid from a single Fe(III) precursor by a sucrose bifunctional hydrothermal method. Journal of Physical Chemistry C, v. 113, n. 36, p. 16002-16008, 2009.

45 COEY, J. M. D. Noncollinear spin arrangement in ultrafine ferrimagnetic crystallites. Physical Review Letters, v. 27, n. 17-25, p. 1140, 1971.

46 PUNTES, V. F.; KRISHNAN, K. M.; ALIVISATOS, A. P. Colloidal nanocrystal shape and size control: the case of cobalt. Science, v. 291, n. 5511, p. 2115-2117, 2001.

47 SUN, S.; ZENG, H.; ROBINSON, D. B.; RAOUX, S.; RICE, P. M.; WANG, S. X.; LI, G. Monodisperse $\mathrm{MFe}_{2} \mathrm{O}_{4}(\mathrm{M}=\mathrm{Fe}, \mathrm{Co}, \mathrm{Mn})$ nanoparticles. Journal of the American Chemical Society, v. 126, n. 1, p. 273-279, 2004.

48 CHEN, H. M.; HSIN, C. F.; CHEN, P. Y.; LIU, R. S.; HU, S. F.; HUANG, C. Y.; LEE, J. F.; JANG, L. Y. Ferromagnetic $\mathrm{CoPt}_{3}$ nanowires: structural evolution from fcc to ordered L12. Journal of the American Chemical Society, v. 131, n. 43, p. 15794-15801, 2009.

49 CHOU, S. W.; SHAU, Y. H.; WU, P. C.; YANG, Y. S.; SHIEH, D. B.; CHEN, C. C. In vitro and in vivo studies of FePt nanoparticles for dual modal CT/MRI molecular imaging. Journal of the American Chemical Society, v. 132, n. 38, p. 13270- 13278, 2010.

50 SUN, S. H. Recent advances in chemical synthesis, self-assembly, and applications of FePt nanoparticles. Advanced Materials, v. 18, n. 4, p. 393-403, 2006.

51 VARANDA, L. C.; JAFELICCI, M. Self-assembled FePt nanocrystals with large coercivity: Reduction of the fcc-to-L10 ordering temperature. Journal of the American Chemical Society, v. 128, n. 34, p. 11062-11066, 2006.

52 ZENG, H.; SUN, S. Syntheses, properties, and potential applications of multicomponent magnetic nanoparticles. Advanced Functional Materials, v. 18, n. 3, p. 391-400, 2008.

53 MÜLLER, R. H.; MAABEN, S.; WEYHERS, H.; SPECHT, F.; LUCKS, J. S. Cytotoxicity of magnetite-loaded polylactide, polylactide/glycolide particles and solid lipid nanoparticles. International Journal of Pharmaceutics, v. 138, n. 1, p. 85-94, 1996.

54 SCWERTMANN, U.; CORNELL, R. M. The iron oxides: structure, properties, reactions, occurrences and uses. 2. ed. New York: John Wiley, 2006. 703 p. 
55 CHIKAZUMI, S. Physics of magnetism. New York: John Wiley, 1964. 554 p.

56 DUNLOP, D. J. Superparamagnetic and single-domain threshold sizes in magnetite. Journal of Geophysical Research, v. 78, n. 11, p. 1780-1793, 1973.

57 RANGANATH, K. V.; GLORIUS, F. Superparamagnetic nanoparticles for asymmetric catalysis-a perfect match. Catalysis Science \& Technology, v. 1, n. 1, p. 13-22, 2011.

58 QUARTA, A.; DI CORATO, R.; MANNA, L.; ARGENTIERE, S.; CINGOLANI, R.; BARBARELLA, G.; PELLEGRINO, T. Multifunctional nanostructures based on inorganic nanoparticles and oligothiophenes and their exploitation for cellular studies. Journal of the American Chemical Society, v. 130, n. 32, p. 10545-10555, 2008.

59 FORTIN, J. P.; WILHELM, C.; SERVAIS, J.; MÉNAGER, C.; BACRI, J. C.; GAZEAU, F. Size-sorted anionic iron oxide nanomagnets as colloidal mediators for magnetic hyperthermia. Journal of the American Chemical Society, v. 129, n. 9, p. 2628-2635, 2007.

60 LAURENT, S.; FORGE, D.; PORT, M.; ROCH, A.; ROBIC, C.; VANDER ELST, L.; MULLER, R. N. Magnetic iron oxide nanoparticles: synthesis, stabilization, vectorization, physicochemical characterizations, and biological applications. Chemical Reviews, v. 108, n. 6, p. 2064-2110, 2008.

61 HU, S. H.; TSAI, C. H.; LIAO, C. F.; LIU, D. M.; CHEN, S. Y. Controlled rupture of magnetic polyelectrolyte microcapsules for drug delivery. Langmuir, v. 24, n. 20, p. 1181111818, 2008.

62 CHERTOK, B.; MOFFAT, B. A.; DAVID, A. E.; YU, F.; BERGEMANN, C.; ROSS, B. D.; YANG, V. C. Iron oxide nanoparticles as a drug delivery vehicle for MRI monitored magnetic targeting of brain tumors. Biomaterials, v. 29, n. 4, p. 487-496, 2008.

63 SUN, C.; LEE, J. S.; ZHANG, M. Magnetic nanoparticles in MR imaging and drug delivery. Advanced Drug Delivery Reviews, v. 60, n. 11, p. 1252-1265, 2008.

64 ANDREAS, K.; GEORGIEVA, R.; LADWIG, M.; MUELLER, S.; NOTTER, M.; SITTINGER, M.; RINGE, J. Highly efficient magnetic stem cell labeling with citrate-coated superparamagnetic iron oxide nanoparticles for MRI tracking. Biomaterials, v. 33, n. 18, p. 4515-4525, 2012. 
65 LIM, E. K.; HUH, Y. M.; YANG, J.; LEE, K.; SUH, J. S.; HAAM, S. pH-Triggered drugreleasing magnetic nanoparticles for cancer therapy guided by molecular imaging by MRI. Advanced Materials, v. 23, n. 21, p. 2436-2442, 2011.

66 GRANCHAROV, S. G.; ZENG, H.; SUN, S.; WANG, S. X.; O'BRIEN, S.; MURRAY, C. B.; KIRTLEY, J. R.; HELD, G. A. Bio-functionalization of monodisperse magnetic nanoparticles and their use as biomolecular labels in a magnetic tunnel junction based sensor. The Journal of Physical Chemistry B, v. 109, n. 26, p. 13030-13035, 2005.

67 QIU, J. D.; PENG, H. P.; LIANG, R. P.; XIA, X. H. Facile preparation of magnetic coreshell $\mathrm{Fe}_{3} \mathrm{O}_{4} @ \mathrm{Au}$ nanoparticle/myoglobin biofilm for direct electrochemistry. Biosensors and Bioelectronics, v. 25, n. 6, p. 1447-1453, 2010.

68 GU, H.; XU, K.; XU, C.; XU, B. Biofunctional magnetic nanoparticles for protein separation and pathogen detection. Chemical Communications, n. 9, p. 941-949, 2006.

69 WEIZMANN, Y.; PATOLSKY, F.; KATZ, E.; WILLNER, I. Amplified DNA sensing and immunosensing by the rotation of functional magnetic particles. Journal of the American Chemical Society, v. 125, n. 12, p. 3452-3454, 2003.

70 LU, A. H.; SALABAS, E. L.; SCHUTH, F. Magnetic nanoparticles: Synthesis, protection, functionalization, and application. Angewandte Chemie-International Edition, v. 46, n. 8, p. 1222- 1244, 2007.

71 FIGUEIREDO, L. C.; LACAVA, B. M.; SKEFF, K.; PELEGRINI, F.; MORAIS, P. C. Magnetic resonance study of maghemite-based magnetic fluid. Journal of Magnetism and Magnetic Materials, v. 320, n. 14, p. e347-e350, 2008.

72 CARUNTU, D.; CUSHING, B. L.; CARUNTU, G.; O'CONNOR, C. J. Attachment of gold nanograins onto colloidal magnetite nanocrystals. Chemistry of materials, v. 17, n. 13, p. 3398-3402, 2005.

73 MARCELO, G.; MUÑOZ-BONILLA, A.; FERNÁNDEZ-GARCÍA, M. Magnetitepolypeptide hybrid materials decorated with gold nanoparticles: study of their catalytic activity in 4-nitrophenol reduction. The Journal of Physical Chemistry C, v. 116, n. 46, p. 24717-24725, 2012.

74 WANG, L.; WANG, L.; LUO, J.; FAN, Q.; SUZUKI, M.; SUZUKI, I. S.; ZHONG, C. J. Monodispersed core-shell Fe3O4@ Au nanoparticles. The Journal of Physical Chemistry B, v. 109, n. 46, p. 21593-21601, 2005. 
75 XU, Z.; HOU, Y.; SUN, S. Magnetic core/shell Fe3O4/Au and Fe3O4/Au/Ag nanoparticles with tunable plasmonic properties. Journal of the American Chemical Society, v. 129, n. 28, 8698-8699, 2007.

76 DANIEL, M. C.; ASTRUC, D. Gold nanoparticles: assembly, supramolecular chemistry, quantum-size-related properties, and applications toward biology, catalysis, and nanotechnology. Chemical Reviews, v. 104, n. 1, p. 293-346, 2004.

77 YU, H.; CHEN, M.; RICE, P. M.; WANG, S. X.; WHITE, R. L.; SUN, S. Dumbbell-like bifunctional $\mathrm{Au}-\mathrm{Fe}_{3} \mathrm{O}_{4}$ nanoparticles. Nano Letters, v. 5, n. 2, p. 379-382, 2005.

78 XU, C.; WANG, B.; SUN, S. Dumbbell-like $\mathrm{Au}-\mathrm{Fe}_{3} \mathrm{O}_{4}$ nanoparticles for target-specific platin delivery. Journal of the American Chemical Society, v. 131, n. 12, p. 4216-4217, 2009.

79 CARUNTU, D.; CUSHING, B. L.; CARUNTU, G.; O'CONNOR, C. J. Attachment of gold nanograins onto colloidal magnetite nanocrystals. Chemistry of Materials, v. 17, n. 13, p. 3398-3402, 2005.

80 MELEDANDRI, C. J.; STOLARCZYK, J. K.; BROUGHAM, D. F. Hierarchical golddecorated magnetic nanoparticle clusters with controlled size. ACS Nano, v. 5, n. 3, p. 1747$1755,2011$.

81 BAO, J.; CHEN, W.; LIU, T.; ZHU, Y.; JIN, P.; WANG, L.; LI, Y. Bifunctional Au-Fe ${ }_{3} \mathrm{O}_{4}$ nanoparticles for protein separation. ACS Nano, v. 1, n. 4, p. 293-298, 2007.

82 ZHANG, L.; XU, Y.; YAO, H.; XIE, L.; YAO, J.; LU, H.; YANG, P. Boronic acid functionalized core-satellite composite nanoparticles for advanced enrichment of glycopeptides and glycoproteins. Chemistry-A European Journal, v. 15, n. 39, p. 1015810166, 2009.

83 CHIN, S. F.; IYER, K. S.; RASTON, C. L. Facile and green approach to fabricate gold and silver coated superparamagnetic nanoparticles. Crystal Growth and Design, v. 9, n. 6, p. 2685-2689, 2009.

84 DU, X.; HE, J.; ZHU, J.; SUN, L.; AN, S. Ag-deposited silica-coated $\mathrm{Fe}_{3} \mathrm{O}_{4}$ magnetic nanoparticles catalyzed reduction of p-nitrophenol. Applied Surface Science, v. 258, n. 7, p. 2717-2723, 2012. 
85 MARCELO, G.; MUÑOZ-BONILLA, A.; FERNÁNDEZ-GARCÍA, M. Magnetitepolypeptide hybrid materials decorated with gold nanoparticles: Study of their catalytic activity in 4-nitrophenol reduction. The Journal of Physical Chemistry C, v. 116, n. 46, p. 24717-24725, 2012.

86 REDDY, A. N.; ANJANEYULU, K.; BASAK, P.; RAO, N. M.; MANORAMA, S. V. A simple approach to the design and functionalization of $\mathrm{Fe}_{3} \mathrm{O}_{4}-\mathrm{Au}$ nanoparticles for biomedical applications. ChemPlusChem, v. 77, n. 4, p. 284-292, 2012.

87 MAHMOUD, K. A.; LAM, E.; HRAPOVIC, S.; LUONG, J. H. Preparation of welldispersed gold/magnetite nanoparticles embedded on cellulose nanocrystals for efficient immobilization of papain enzyme. ACS Applied Materials \& Interfaces, v. 5, n. 11, p. 4978-4985, 2013.

88 ZHANG, M.; ZHENG, J.; ZHENG, Y.; XU, J.; HE, X.; CHEN, L.; FANG, Q. Preparation, characterization and catalytic activity of core-satellite $\mathrm{Au} / \mathrm{Pdop} / \mathrm{SiO}_{2} / \mathrm{Fe}_{3} \mathrm{O}_{4}$ magnetic nanocomposites. RSC Advances, v. 3, n. 33, p. 13818-13824, 2013.

89 LIANG, W.; YI, W.; LI, Y.; ZHANG, Z.; YANG, M.; HU, C.; CHEN, A. A novel magnetic $\mathrm{Fe}_{3} \mathrm{O}_{4} @$ gold composite nanomaterial: synthesis and application in regeneration-free immunosensor. Materials Letters, v. 64, n. 23, p. 2616-2619, 2010.

90 MARTIN, M. N.; BASHAM, J. I.; CHANDO, P.; EAH, S. K. Charged gold nanoparticles in non-polar solvents: 10-min synthesis and 2D self-assembly. Langmuir, v. 26, n. 10, p. 7410-7417, 2010.

91 VIEIRA, A. P.; BERNDT, G.; DE SOUZA JUNIOR, I. G.; DI MAURO, E.; PAESANO JR, A.; DE SANTANA, H.; DA COSTA, A. C. S.; ZAIA, C. T. B. V.; ZAIA, D. A. M. Adsorption of cysteine on hematite, magnetite and ferrihydrite: FT-IR, Mössbauer, EPR spectroscopy and X-ray diffractometry studies. Amino Acids, v. 40, n. 1, p. 205-214, 2011.

92 KUZNETSOV, B. A.; BYZOVA, N. A.; SHUMAKOVICH, G. P. The effect of the orientation of cytochrome c molecules covalently attached to the electrode surface upon their electrochemical activity. Journal of Electroanalytical Chemistry, v. 371, v. 1-2, p. 85-92, 1994.

93 REICHLIN, M. Use of glutaraldehyde as a coupling agent for proteins and peptides. Methods in Enzymology, v. 70, p. 159-165, 1980 
94 PILLAI, V.; KUMAR, P.; HOU, M. J.; AYYUB, P.; SHAH, D. O. Preparation of nanoparticles of silver halides, superconductors and magnetic materials using water-in-oil microemulsions as nano-reactors. Advances in Colloid and Interface Science, v. 55, p. 241269, 1995.

95 HYEON, T. Chemical synthesis of magnetic nanoparticles. Chemical Communications, n. 8, p. 927-934, 2003.

96 ZHU, M.; DIAO, G. Synthesis of porous Fe3O4 nanospheres and its application for the catalytic degradation of xylenol orange. The Journal of Physical Chemistry C, v. 115 n. 39, p. $18923-18934.2011$.

97 GOIA, D.; MATIJEVIĆ, E. Tailoring the particle size of monodispersed colloidal gold. Colloids and Surfaces A: Physicochemical and Engineering Aspects, v. 146, n. 1, p. 139-152, 1999.

98 PUDDEPHATT, RICHARD J. The chemistry of gold. Amsterdan: Elsevier, 1978. 274 p.

99 CAMPBELL, C. T.; PARKER, S. C.; STARR, D. E. The effect of size-dependent nanoparticle energetics on catalyst sintering. Science, v. 298, n. 5594, p. 811-814, 2002.

100 GAN, N.; JIN, H.; LI, T.; ZHENG, L. $\mathrm{Fe}_{3} \mathrm{O}_{4} / \mathrm{Au}$ magnetic nanoparticle amplification strategies for ultrasensitive electrochemical immunoassay of alfa-fetoprotein. International Journal of Nanomedicine, v. 6, p. 3259-3269, 2011.

101 WU, C. C.; CHEN, D. H. Facile green synthesis of gold nanoparticles with gum arabic as a stabilizing agent and reducing agent. Gold Bulletin, v. 43, n. 4, p. 234-240, 2010.

102 LONG, N. N.; KIEM, C. D.; DOANH, S. C.; NGUYET, C. T.; HANG, P. T.; THIEN, N. D.; QUYNH, L. M. Synthesis and optical properties of colloidal gold nanoparticles. Journal of Physics: Conference Series, v. 187, n. 1, p. 012026-012033, 2009.

103 FANO, U.; SPENCER, L. V.; BERGER, M. J. Penetration and diffusion of x rays. In: Neutrons and related gamma ray problems/neutronen und verwandte gammastrahlprobleme. Berlin: Springer, 1959. p. 660-817.

104 ANDRADE, S. S.; RABELO, D.; GARG, V. K.; OLIVEIRA, A. C.; MORAIS, P. C. Synthesis of magnetite nanoparticles in hydrophobic styrene-divinylbenzene copolymer templates. Journal of Magnetism and Magnetic Materials, v. 289, p. 25-27, 2005. 
105 XIN, X.; WEI, Q.; YANG, J.; YAN, L.; FENG, R.; CHEN, G.; DU, B.; LI, H. Highly efficient removal of heavy metal ions by amine-functionalized mesoporous $\mathrm{Fe}_{3} \mathrm{O}_{4}$ nanoparticles. Chemical Engineering Journal, v. 184, p. 132-140, 2012.

106 JIA, J.; JIMMY, C. Y.; ZHU, X. M.; CHAN, K. M.; WANG, Y. X. J. Ultra-fast method to synthesize mesoporous magnetite nanoclusters as highly sensitive magnetic resonance probe. Journal of Colloid and Interface Science, v. 379, n. 1, p. 1-7, 2012.

107 CORREA-DUARTE, M. A.; GIERSIG, M.; KOTOV, N. A.; LIZ-MARZÁN, L. M. Control of packing order of self-assembled monolayers of magnetite nanoparticles with and without $\mathrm{SiO}_{2}$ coating by microwave irradiation. Langmuir, v. 14, n. 22, p. 6430-6435, 1998.

108 KIM, M. P.; KANG, D. J.; JUNG, D. W.; KANNAN, A. G.; KIM, K. H.; KU, K. H.; JANG, S. G.; CHAE, W. S.; YI, G. R.; KIM, B. J. Gold-decorated block copolymer microspheres with controlled surface nanostructures. ACS Nano, v. 6, n. 3, p. 2750-2757, 2012.

109 GHOSH, S. K.; PAL, T. Interparticle coupling effect on the surface plasmon resonance of gold nanoparticles: from theory to applications. Chemical Reviews, v. 107, n. 11, p. 47974862, 2007

110 GRASSESCHI, D.; ZAMARION, V. M.; ARAKI, K.; TOMA, H. E. Surface enhanced Raman scattering spot tests: a new insight on Feigl's analysis using gold nanoparticles. Analytical Chemistry, v. 82, n. 22, p. 9146-9149, 2010.

111 TOMA, H. E.; ZAMARION, V. M.; TOMA, S. H.; ARAKI, K. The coordination chemistry at gold nanoparticles. Journal of the Brazilian Chemical Society, v. 21, n. 7 , 1158-1176, 2010.

112 BONIFACIO, L. S.; GORDIJO, C. R.; CONSTANTINO, V. R.; SILVA, D. O.; KIYOHARA, P. K.; ARAKI, K.; TOMA, H. E. Optical changes and writing on hydrotalcite supported gold nanoparticles. Journal of Nanoscience and Nanotechnology, v. 8, n. 1, p. 274-279, 2008.

113 CHENG, C.; WEN, Y.; XU, X.; GU, H. Tunable synthesis of carboxyl-functionalized magnetite nanocrystal clusters with uniform size. Journal of Materials Chemistry, v. 19, n. 46, p. 8782-8788, 2009. 
114 YAMAURA, M.; CAMILO, R. L.; SAMPAIO, L. C.; MACEDO, M. A.; NAKAMURA, M.; TOMA, H. E. Preparation and characterization of (3-aminopropyl) triethoxysilane-coated magnetite nanoparticles. Journal of Magnetism and Magnetic Materials, v. 279, n. 2, p. 210-217, 2004.

115 DOLCI, S.; IERARDI, V.; REMSKAR, M.; JAGLIČIĆ, Z.; PINEIDER, F.; BONI, A.; PAMPALONI, G.; VERACINI, C. A.; DOMENICI, V. Chemical-physical properties, morphology, and magnetic investigations on new cystine functionalized ultra-small superparamagnetic iron-oxide nanoparticles. Journal of Materials Science, v. 48, n. 3, p. 12831291, 2013.

116 KOLEVA, B.; SPITELLER, M.; KOLEV, T. Polarized spectroscopic elucidation of Nacetyl-1-cysteine, 1-cysteine, 1-cystine, 1-ascorbic acid and a tool for their determination in solid mixtures. Amino Acids, v. 38, n. 1, p. 295-304, 2010.

117 NATIONAL INSTITUTE OF STANDARDS AND TECHNOLOGY (NIST). IR spectrum. 2009. Disponível: <http://webbook.nist.gov/cgi/cbook.cgi?Name=Lcystine+\&Units=SI\&cIR=on\#IR-Spec $>$. Acesso em: 11 de ago. 2016.

118 ARYAL, S.; REMANT, B. K. C.; DHARMARAJ, N.; BHATTARAI, N.; KIM, C. H.; KIM, H. Y. Spectroscopic identification of S Au interaction in cysteine capped gold nanoparticles. Spectrochimica Acta Part A: Molecular and Biomolecular Spectroscopy, v. 63, n. 1, p. 160-163, 2006.

119 MA, Z.; HAN, H. One-step synthesis of cystine-coated gold nanoparticles in aqueous solution. Colloids and Surfaces A: Physicochemical and Engineering Aspects, v. 317, n. 1, p. 229-233, 2008.

120 WANG, J.; LI, Y. F.; HUANG, C. Z.; WU, T. Rapid and selective detection of cysteine based on its induced aggregates of cetyltrimethylammonium bromide capped gold nanoparticles. Analytica Chimica Acta, v. 626, n. 1, p. 37-43, 2008.

121 LIU, H. Q.; TIAN, Y.; DENG, Z. F. Morphology-dependent electrochemistry and electrocatalytical activity of cytochrome c. Langmuir, v. 23, p. 9487-9494, 2007.

122 JACKSON, M.; MANTSCH, H. H. The use and misuse of ftir spectroscopy in the determination of protein-structure. Critical Reviews in Biochemistry and Molecular Biology, v. 30, p. 95-120, 1995.

123 NELSON, D. L; COX M. M., Lehninger principles of biochemistry. 4 ed. New York: WH Freeman, 2005. 473 p. 
124 LI, R.; LIU, J. Mechanistic investigation of the charge storage process of pseudocapacitive Fe3O4 nanorod film. Electrochimica Acta, v. 120, p. 52-56, 2014.

125 COTTINEAU, T.; TOUPIN, M.; DELAHAYE, T.; BROUSSE, T.; BELANGER, D. Nanostructured transition metal oxides for aqueous hybrid electrochemical supercapacitors. Applied Physics A, v. 82, n. 4, p. 599-606, 2006.

126 WU, N. L.; WANG, S. Y.; HAN, C. Y.; WU, D. S.; SHIUE, L. R. Electrochemical capacitor of magnetite in aqueous electrolytes. Journal of Power Sources, v. 113, n. 1, p. 173-178. 2003.

127 ALLEN, P. D.; HAMPSON, N. A.; BIGNOLD, G. J. The electrodissolution of magnetite: Part I. The electrochemistry of Fe3O4/C discs-potentiodynamic experiments. Journal of Electroanalytical Chemistry and Interfacial Electrochemistry, v. 99, n. 3, 299-309, 1979.

128 VERINK, E. D. Simplified procedure for constructing Pourbaix diagrams. In: REVIE, R.W. (Ed.). Uhlig's corrosion handbook. 3. ed. New York: Wiley, 2011. 14 p.

129 SHEIKHOLESLAMI, M.; GORJI-BANDPY, M. Free convection of ferrofluid in a cavity heated from below in the presence of an external magnetic field. Powder Technology, v. 256, p, 490-498, 2014.

130 NAKAHAMA, S.; MURRAY, R. W. The effect of composition of a ferrocene-containing redox polymer on the electrochemistry of its thin film coatings on electrodes. Journal of Electroanalytical Chemistry and Interfacial Electrochemistry, v. 158, n. 2, p. 303-322, 1983.

131 PIMPIN, A.; SRITURAVANICH, W. Review on micro-and nanolithography techniques and their applications. Engineering Journal, v. 16, n. 1, p. 37-56, 2011

132 GRIGORESCU, A. E.; HAGEN, C. W. Resists for sub-20-nm electron beam lithography with a focus on HSQ: state of the art. Nanotechnology, v. 20, n. 29, p. 292001-292032, 2009.

133 TSENG, A. A. Recent developments in micromilling using focused ion beam technology. Journal of Micromechanics and Microengineering, v. 14, n. 4, p. R15-R34, 2004.

134 TSENG, A. A.; NOTARGIACOMO, A.; CHEN, T. P. Nanofabrication by scanning probe microscope lithography: A review. Journal of Vacuum Science \& Technology B, v. 23, n. 3, p. 877-894, 2005. 
135 CHIU, G. T.; SHAW, J. M. Optical lithography: introduction. IBM Journal of Research and Development, v. 41, n. 1.2, p. 3-6, 1997.

136 ROGERS, J. A.; NUZZO, R. G. Recent progress in soft lithography. Materials Today, v. 8, n. 2, p. 50-56, 2005.

137 CHOU, S. Y.; KRAUSS, P. R.; RENSTROM, P. J. Imprint lithography with 25nanometer resolution. Science, v. 272, n. 5258, p. 85-87, 1996.

138 BARDEA, AMOS; NAAMAN, RON. Magnetolithography: from the bottom-up route to high throughput. Advances in Imaging and Electron Physics, v. 164, p. 1, 2010.

139 BARDEA, A.; NAAMAN, R. Magnetolithography: from bottom-up route to high throughput. Small, v. 5, n. 3, p. 316-319, 2009.

140 BARDEA, A.; NAAMAN, R. Submicrometer chemical patterning with high throughput using magnetolithography. Langmuir, v. 25, n. 10, p. 5451-5454, 2009.

141 KUMAR, T. A.; BARDEA, A.; SHAI, Y.; YOFFE, A.; NAAMAN, R. Patterning gradient properties from sub-micrometers to millimeters by magnetolithography. Nano letters, v. 10, n. 6, 2262-2267, 2010.

142 NAAMAN, R. Magnetolithographic patterning of inner walls of a tube: a new dimension in microfluidics and sequential microreactors. Journal of the American Chemical Society, v. 131, n. 51, p. 18260-18262, 2009.

143 MCLELLAN, J. M.; SIEKKINEN, A.; XIONG, Y.; LI, Z. Y.; XIA, Y. Facile synthesis of gold-silver nanocages with controllable pores on the surface. Journal of the American Chemical Society, v. 128, n. 46, p. 14776-14777, 2006.

144 YIN, Y.; ERDONMEZ, C.; ALONI, S.; ALIVISATOS, A. P. Faceting of nanocrystals during chemical transformation: from solid silver spheres to hollow gold octahedra. Journal of the American Chemical Society, v. 128, n. 39, p. 12671-12673, 2016.

145 SKRABALAK, S. E.; CHEN, J.; SUN, Y.; LU, X.; AU, L.; COBLEY, C. M.; XIA, Y. Gold nanocages: synthesis, properties, and applications. Accounts of Chemical Research, v. 41, n. 12, p. 1587-1595, 2008. 
146 SUN, Y.; MAYERS, B. T.; XIA, Y. Template-engaged replacement reaction: a one-step approach to the large-scale synthesis of metal nanostructures with hollow interiors. Nano Letters, v. 2, n. 5, p. 481-485, 2002.

147 SUI, Y.; FU, W.; ZENG, Y.; YANG, H.; ZHANG, Y.; CHEN, H.; LI. Y.; LI, M.; ZOU, $\mathrm{G}$. Synthesis of $\mathrm{Cu} 2 \mathrm{O}$ nanoframes and nanocages by selective oxidative etching at room temperature. Angewandte Chemie International Edition, v. 49, n. 25, p. 4282-4285, 2010.

148 KUO, C. H.; HUANG, M. H. Fabrication of truncated rhombic dodecahedral Cu2O nanocages and nanoframes by particle aggregation and acidic etching. Journal of the American Chemical Society, v. 130, n. 38, p. 12815-12820, 2008.

149 AN, K.; KWON, S. G.; PARK, M.; NA, H. B.; BAIK, S. I.; YU, J. H.; KIM, D.; SON. J. S.; KIM, Y. W.; SONG, I. C.; MOON, W. K. PARK. H. M.; HYEON, T. Synthesis of uniform hollow oxide nanoparticles through nanoscale acid etching. Nano letters, v. 8, n. 12, p. 4252-4258, 2008.

150 CAO, H.; QIAN, X.; WANG, C.; MA, X.; YIN, J.; ZHU, Z. High symmetric 18-facet polyhedron nanocrystals of Cu7S4 with a hollow nanocage. Journal of the American Chemical Society, v. 127, n. 46, p. 16024-16025, 2005.

151 WANG, L.; TANG, F.; OZAWA, K.; CHEN, Z. G.; MUKHERJ, A.; ZHU, Y.; ZOU. J.; CHENG. H. M.; LU, G. Q. A general single-source route for the preparation of hollow nanoporous metal oxide structures. Angewandte Chemie, v. 121, n. 38, p. 7182-7185, 2009.

152 YANG, H. G.; ZENG, H. C. Self-construction of hollow SnO2 octahedra based on twodimensional aggregation of nanocrystallites. Angewandte Chemie, v. 116, n. 44, p. 60566059, 2004.

153 WANG, Z.; LUAN, D.; LI, C. M.; SU, F.; MADHAVI, S.; BOEY, F. Y. C., LOU, X. W. Engineering nonspherical hollow structures with complex interiors by template-engaged redox etching. Journal of the American Chemical Society, v. 132, n. 45, p. 16271-16277, 2010 .

154 HE, T.; CHEN, D.; JIAO, X.; WANG, Y. Co3O4 Nanoboxes: surfactant-templated fabrication and microstructure characterization. Advanced Materials, v. 18, n. 8, p. 10781082, 2006.

155 LOU, X. W.; YUAN, C.; ZHANG, Q.; ARCHER, L. A. Platinum-functionalized octahedral silica nanocages: synthesis and characterization. Angewandte Chemie International Edition, v. 45, n. 23, p. 3825-3829, 2006. 
156 WANG, Z.; LUAN, D.; BOEY, F. Y. C.; LOU, X. W. Fast formation of SnO2 nanoboxes with enhanced lithium storage capability. Journal of the American Chemical Society, v.133, n. 13, p. 4738-4741, 2011.

157 LU, X.; CHEN, J.; SKRABALAK, S. E.; XIA, Y. Galvanic replacement reaction: a simple and powerful route to hollow and porous metal nanostructures. Proceedings of the Institution of Mechanical Engineers, Part N: Journal of Nanoengineering and Nanosystems, v. 221, n. 1, p. 1-16, 2007.

158 LOU, X. W. D.; ARCHER, L. A.; YANG, Z. Hollow micro-/nanostructures: synthesis and applications. Advanced Materials, v. 20, n. 21, 3987-4019, 2008.

159 KREIBIG, U.; VOLLMER, M. Optical properties of metal clusters. Heidelberg: Springer-Verlag, 1995. 535 p. (Springer Series in Material Science; v. 25).

123 NELSON, D. L; COX M. M., Lehninger principles of biochemistry, 4 ed, New York: WH Freeman and Company, 2005. 473 p.

160 EL-SAYED, M. A. Some interesting properties of metals confined in time and nanometer space of different shapes. Accounts of Chemical Research, v. 34, n. 4, p. 257-264, 2001.

161 KREIBIG, U.; GENZEL, L. Optical absorption of small metallic particles. Surface Science, v. 156, p. 678-700, 1985.

162 CHEN, J.; WILEY, B. J.; LI, Z. Y.; CAMPBELL, D.; SAEKI, F.; CANG, H.; AU, L.; LEE, J.; LI, X.; XIA, Y. Gold nanocages: engineering their structure for biomedical applications. Advanced Materials, v. 17, p.2255-2261, 2005.

163 NOVOTNY, L.; VAN HULST, N. Antennas for light. Nature Photonics, v. 5, n. 2, p. 83-90, 2011.

164 ADATO, R.; ALTUG, H. In-situ ultra-sensitive infrared absorption spectroscopy of biomolecule interactions in real time with plasmonic nanoantennas. Nature

Communications, v. 4, n. 2154, 2013.

165 D'ANDREA, C.; BOCHTERLE, J.; TOMA, A.; HUCK, C; NEUBRECH, F.; MESSINA, E.; FAZIO, B.; MARAGO, O. M.; DI FABRIZIO, E.; DE LA CHAPELLE, M. L.; GUCCIARDI, P. G.; PUCCI, A. Optical nanoantennas for multiband surface-enhanced infrared and Raman spectroscopy. ACS Nano, v. 7, n. 4, p. 3522-3531, 2013. 
166 RYCENGA, M.; HOU, K. K.; COBLEY, C. M.; SCHWARTZ, A. G.; CAMARGO, P. H. C.; XIA, Y. Probing the surface-enhanced Raman scattering properties of $\mathrm{Au}-\mathrm{Ag}$ nanocages at two different excitation wavelengths. Physical Chemistry Chemical Physics, v. 11, p. 28, p. 5903-5908, 2009.

167 TAO, A.; SINSERMSUKSAKUL, P.; YANG, P. Polyhedral silver nanocrystals with distinct scattering signatures. Angewandte Chemie International Edition, v. 45, n. 28, p. 4597-4601, 2006.

168 SKRABALAK, S. E.; AU, L.; LI, X.; XIA, Y. Facile synthesis of Ag nanocubes and Au nanocages. Nature Protocols, v. 2, n. 9, p. 2182-2190, 2007.

169 GUO, S.; DONG, S.; WANG, E. A general method for the rapid synthesis of hollow metallic or bimetallic nanoelectrocatalysts with urchinlike morphology. Chemistry-A European Journal, v. 14, n. 15, p. 4689-4695, 2008.

170 GUO, S.; DONG, S.; WANG, E. A general route to construct diverse multifunctional $\mathrm{Fe} 3 \mathrm{O} 4 /$ metal hybrid nanostructures. Chemistry-A European Journal, v. 15, n. 10, p. 24162424, 2009.

171 LIANG, H.; WANG, W.; HUANG, Y.; ZHANG, S.; WEI, H.; XU, H. Controlled synthesis of uniform silver nanospheres. The Journal of Physical Chemistry C, v. 114, n. 16, p. 7427-7431, 2010.

172 KOCZKUR, K. M.; MOURDIKOUDIS, S.; POLAVARAPU, L.; SKRABALAK, S. E. Polyvinylpyrrolidone (PVP) in nanoparticle synthesis. Dalton Transactions, v. 44, n. 41, p. 17883-17905, 2015.

173 SUN, Y.; XIA, Y. Shape-controlled synthesis of gold and silver nanoparticles. Science, v. 298, n. 5601, p. 2176-2179, 2002.

174 ZHANG, Q.; COBLEY, C.; AU, L.; MCKIERNAN, M.; SCHWARTZ, A.; WEN, L. P., CHEN, J.; XIA, Y. Production of Ag nanocubes on a scale of $0.1 \mathrm{~g}$ per batch by protecting the NaHS-mediated polyol synthesis with argon. ACS Applied Materials \& Interfaces, v. 1, n. 9 , p. 2044-2048, 2009.

175 ZHANG, Q.; LI, W.; MORAN, C.; ZENG, J.; CHEN, J.; WEN, L. P.; XIA, Y. Seedmediated synthesis of Ag nanocubes with controllable edge lengths in the range of 30-200 $\mathrm{nm}$ and comparison of their optical properties. Journal of the American Chemical Society, v. 132, n. 32, p. 11372-11378, 2010. 
176 SZKLARSKA-SMIALOWSKA, Z. Pitting corrosion of metals. Houston: National Association of Corrosion Engineers, 1986. 431 p.

177 ROOSEN, A. R.; CARTER, W. C. Simulations of microstructural evolution: anisotropic growth and coarsening. Physica A: Statistical Mechanics and its Applications, v. 261, n. 1, p. 232-247, 1998.

178 MALLARD, W. C.; GARDNER, A. B.; BASS, R. F; SLIFKIN, L. M. Self-diffusion in silver-gold solid solutions. Physical Review, v. 129, n. 2, p. 617-625, 1963.

179 ERLEBACHER, J.; AZIZ, M. J.; KARMA, A.; DIMITROV, N.; SIERADZKI, K. Evolution of nanoporosity in dealloying. Nature, v. 410, n. 6827, p. 450-453, 2001.

180 SUN, Y.; XIA, Y. Mechanistic study on the replacement reaction between silver nanostructures and chloroauric acid in aqueous medium. Journal of the American Chemical Society, v. 126, n. 12, p. 3892-3901, 2014.

181 OLDENBURG, S. J., JACKSON, J. B.; WESTCOTT, S. L.; HALAS, N. J. Infrared extinction properties of gold nanoshells. Applied Physics Letters, v. 75, n. 19, p. 2897-2899, 1999.

182 LU, X.; AU, L.; MCLELLAN, J.; LI, Z. Y.; MARQUEZ, M.; XIA, Y. Fabrication of cubic nanocages and nanoframes by dealloying Au/Ag alloy nanoboxes with an aqueous etchant based on $\mathrm{Fe}(\mathrm{NO} 3) 3$ or NH4OH. Nano letters, v. 7, p.1764-1769, 2007.

183 MASON, M.; WEAVER, W. The settling of small particles in a fluid. Physical Review, v. 23, n.3, p. 412-426, 1924

184 MATTEINI, P.; DE ANGELIS, M.; ULIVI, L.; CENTI, S.; PINI, R. Concave gold nanocube assemblies as nanotraps for surface-enhanced Raman scattering-based detection of proteins. Nanoscale, v. 7, p. 3474-3480, 2015.

185 LIU, S. H.; SAIDI, W. A.; ZHOU, Y.; FICHTHORN, K. A. Synthesis of $\{111\}$-faceted Au nanocrystals mediated by polyvinylpyrrolidone: insights from density-functional theory and molecular dynamics. The Journal of Physical Chemistry C, v. 119, n. 21, p. 1198211990, 2015.

186 KIM, F.; CONNOR, S.; SONG, H.; KUYKENDALL, T.; YANG, P. Platonic gold nanocrystals. Angewandte Chemie, v. 116, n. 28, p. 3759-3763, 2004. 
187 XIA, X.; ZENG, J., OETJEN, L. K.; LI, Q.; XIA, Y. Quantitative analysis of the role played by poly (vinylpyrrolidone) in seed-mediated growth of Ag nanocrystals. Journal of the American Chemical Society, v. 134, n. 3, p. 1793-1801, 2012.

188 KYRYCHENKO, A.; KORSUN, O. M.; GUBIN, I. I.; KOVALENKO, S. M.; KALUGIN, O. N. Atomistic simulations of coating of silver nanoparticles with poly (vinylpyrrolidone) oligomers: Effect of oligomer chain length. The Journal of Physical Chemistry C, v. 119, n. 14, p. 7888-789, 2015. 


\section{Anexo}

- Publicações durante o período do doutorado

1 ARAUJO-CHAVES, J. C.; KAWAI, C.; MELO, A. F. A. A; MUGNOL, K. C. U.; NASCIMENTO, O. R.; ARANTES, J. T.; CRESPILHO, F. N.; NANTES, I. L. Interaction and reaction of the antioxidant MnIII [Meso-Tetrakis (4-NMethyI Pyridinium) Porphyrin] with the apoptosis reporter lipid phosphatidylserine. Current Physical Chemistry, v. 3, n. 2, p. 187-198, 2013.

2 MELO, A. F. A. A.; LUZ, R. A.; IOST, R. M.; NANTES, I. L.; CRESPILHO, F. N. Highly stable magnetite modified with chitosan, ferrocene and enzyme for application in magnetoswitchable bioelectrocatalysis. Journal of the Brazilian Chemical Society, v. 24, n. 2, p. 285-294, 2013.

3 MELO, A. F. A. A.; CARVALHO, V. A.; PAGNONCELli, K. C.; CRESPILHO, F. N. Single microparticle applied in magnetic-switchable electrochemistry. Electrochemistry Communications, v. 30, p. 79-82, 2013.

4 SANTOS, G. P.; MELO, A. F. A. A.; CRESPILHO, F. N. Magnetically controlled singlenanoparticle detection via particle-electrode collisions. Physical Chemistry Chemical Physics, v. 16, n. 17, p. 8012-8018, 2014.

5 CABRERA, F. C.; MELO, A. F. A. A.; SOUZA, J. C. P.; JOB, A. E.; CRESPILHO, F. N. A flexible lab-on-a-chip for the synthesis and magnetic separation of magnetite decorated with gold nanoparticles. Lab on a Chip, v. 15, p. 1835-1841, 2015.

6 OSICA, I.; MELO. A. F. A. A.; IMAMURA, G.; YOSHIKAWA, G.; JI, Q.; HILL, J. P.; CRESPILHO, F. N.; KURZYDŁOWSKI, K. J.; ARIGA, K. Fabrication of silica-protein hierarchical nanoarchitecture with gas-phase sensing activity. Journal of Nanoscience and Nanotechnology, 2016. 